\title{
A VIABILIDADE ECONÔMICA DOS REFLORESTAMENTOS COM ESSÊNCIAS NATIVAS BRASILEIRAS PARA A PRODUÇÃO DE TORAS - O CASO DO ESTADO DE SÃO PAULO
}

\section{JOSÉ ARIMATÉIA RABELO MACHADO}

Engenheiro Agrônomo

Orientador: Prof. Dr. CARLOS JOSÉ CAETANO BACHA

Dissertação apresentada à Escola Superior de Agricultura "Luiz de Queiroz", Universidade de São Paulo, para obtenção do título de Mestre em Ciências, Área de Concentração: Economia Aplicada.

PIRACICABA

Estado de São Paulo - Brasil

Abril - 2000 
Dados Internacionais de Catalogação na Publicação (CIP)

DIVISÃO DE BIBLIOTECA E DOCUMENTAÇÃO - Campus "Luiz de Queiroz"/USP

\author{
Machado, José Arimatèia Rabelo \\ A viabilidade econômica dos reflorestamentos com essências nativas brasileiras para \\ a produção de toras - o caso do Estado de São Paulo / José Arimatéia Rabelo \\ Machado. - Piracicaba, 2000. \\ $186 \mathrm{p}$. \\ Dissertação (mestrado) - - Escola Superior de Agricultura Luiz de Queiroz, 2000. \\ Bibliografia. \\ 1. Economia florestal 2. Essência florestal nativa 3. Rentabilidade 4. \\ Reflorestamento 5. Tora 6. Viabilidade econômica I. Titulo
}

CDD 338.17493

"Permitida a cópia total ou parcial deste documento, desde que citada a fonte - 0 autor" 
Dedico

À Deus, por nunca ter me deixado perder a fé

Aos meus pais Joaquim e Maria Socorro

À minha amada esposa Cristina

Ao meu filho Vinícius 


\section{Agradecimentos}

Aos meus pais, Joaquim e Maria Socorro, pelo exemplo de luta e honestidade, que sempre marcaram suas vidas.

À minha esposa Cristina pelo apoio, compreensão e amor.

Ao meu filho Vinícius, que nasceu, engatinhou, andou e hoje fala "papai trabalhar Piracibaca", pelo belo exemplo do sentido da vida.

Ao meu orientador Pro. Dr. Carlos José Caetano Bacha, por ser um verdadeiro "mestre" na orientação deste humilde aprendiz.

Ao Instituto Florestal do Estado de São Paulo que me permitiu realizar este mestrado.

À minha chefe de seção Dr. Ana Cristina M. F. Siqueira pelo apoio dado para a realização do mestrado.

Ao Prof. Dr. Paulo Y. Kageyama pelas importantes sugestões dadas no seminário.

Ao Prof. Dr. Ricardo Shirota, cujas contribuições no seminário e qualificação foram muito importantes para o aprimoramento desta dissertação.

Ao Prof. Dr. Evaristo M. Neves, pelas sugestões dadas na qualificação, que serviram para enriquecer esta dissertação.

Ao CNPQ, pelo auxílio e incentivo através da concessão da bolsa para o curso de mestrado.

Aos pesquisadores científicos do Instituto Florestal que me auxiliaram na obtenção das informações necessárias.

Aos funcionários do Departamento de Economia, Administração e Sociologia Rural.

Aos professores do Departamento de Economia, Administração e Sociologia Rural, com especial atenção aos que foram meus professores: Carlos Bacha, Rodolfo Hoffmann, Adriano Azevedo Filho, João Martinez, Joaquim Bento, Paulo Cidade, Ana Lúcia, Pedro Valentim e Ricardo Shirota. 


\section{SUMÁRIO}

Página

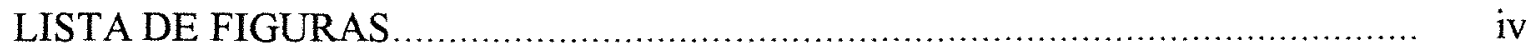

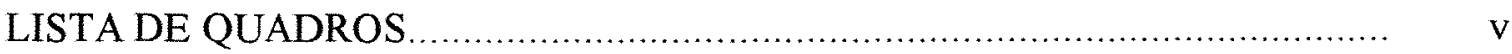

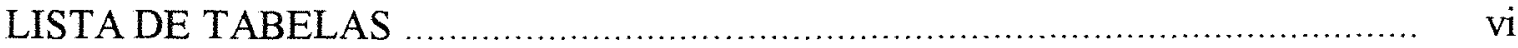

RESUMO

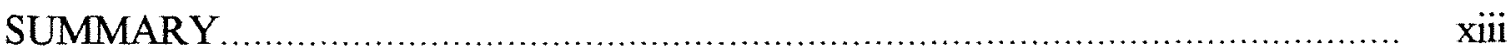

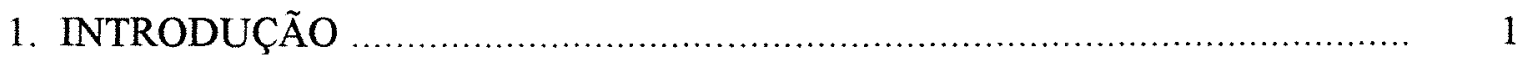

1.1 Delimitação do Problema em Estudo ....................................... 2

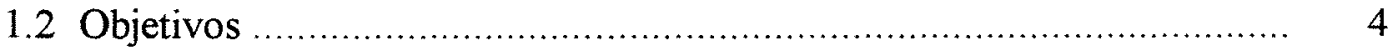

1.3 Organização do Trabalho .......................................................... 5

2. INSTRUMENTOS DE INCENTIVO AO REFLORESTAMENTO E/OU CONTROLE DO DESMATAMENTO ....................................

2.1 Instrumentos do Poder Público para Incentivo ao Reflorestamento e /ou Manutenção das Florestas Nativas........................................... 7

2.1.1 Instrumentos Baseados no Mercado ........................... 7

2.1.2 Instrumentos de Comando e Controle ......................... 9

2.2 Instrumentos Privados para Incentivo ao Reflorestamento e/ou

Manutenção das Florestas Nativas..

3. PRODUÇÃO E DEMANDA DE MADEIRAS DE ESSÊNCIAS NATIVAS E A LEGISLAÇÃO FLORESTAL BRASILEIRA

3.1 Produção e Demanda de Madeira em Tora de Nativas no Brasil........

3.1.1 Evolução da Produção de Toras Nativas no Brasil e em suas Regiões.

3.1.2 Potencialidade das Reservas Remanescentes................. 13

3.1.3 Consumo de Madeira Nativa 
3.2 O Processo de Certificação de Produtos oriundos de Madeiras Nativas no Brasil.

3.3 A Legislação Florestal Brasileira ………………….......................... 21

3.3.1 Áreas com Exploração Proibida ........................................ 21

3.3.2 Áreas com Exploração Limitada ....................................... 21

3.3.3 Áreas com Exploração Permitida ......................................... 22

4. PESQUISAS E RESULTADOS COM REFLORESTAMENTO DE ESSÊNCIAS NATIVAS

4.1 As Pesquisas com Essências Nativas.............................................. 25

4.1.1 As Espécies Pesquisadas ................................................ 27

4.1.2 A Evolução das Áreas de Pesquisa ................................... 31

4.2 A Experiência do Instituto Florestal em São Paulo............................ 39

4.2.1 Os Resultados obtidos pelo Instituto Florestal.................... 39

4.2.2 Possiveis Projetos Técnicos de Reflorestamento com

Essências Nativas.

5. RENTABILIDADE ECONÔMICA DOS REFLORESTAMENTOS COM ESSÊNCIAS NATIVAS.

5.1 Considerações Preliminares

5.2 Escolha dos Métodos de Avaliação Econômica de Projetos.

5.3 Estimativas dos Indicadores de Avaliação para os Projetos

Selecionados $-\mathrm{a}$ análise determinista.

5.4 O Impacto de Novos Cenários sobre os Indicadores de

Rentabilidade $-\mathrm{a}$ análise de sensibilidade.

5.5 As Estimativas dos Indicadores de Avaliação para os Projetos

Selecionados - a análise de risco pela simulação de Monte Carlo...

6. CONCLUSÕES

REFERÊNCIAS BIBLIOGRÁFICAS _..................................................

APÊNDICE 1 - Descrição das Áreas com Exploração Proibida no Brasil........ 83

APÊNDICE 2 - Descrição das Áreas com Exploração Limitada no Brasil.......... 86 
APÊNDICE 3 - Relação de Trabalhos Cientificos sobre Essências Nativas no Brasil

APÊNDICE 4 - Fluxos de Caixa dos Projetos de Reflorestamento Selecionados

APÊNDICE 5 - Informações Gerais sobre Beneficios e Custos do

Reflorestamento com o Pau-marfim.

APÊNDICE 6 - Informações Gerais sobre Beneficios e Custos do Reflorestamento com o pinheiro-brasileiro.

APÊNDICE 7 - Informações Gerais sobre Benefícios e Custos do

Reflorestamento com a Araruva.

APÊNDICE 8 - Informações Gerais para a Elaboração de Novos Cenários

(Otimistas ou Pessimistas) para os Projetos de

Reflorestamento com Nativas.

APÊNDICE 9 - Aspectos Gerais da Análise de Risco pela Simulação de Monte Carlo. 


\section{LISTA DE FIGURAS}

Página

1 Produção de madeira em toras de espécies florestais nativas por grandes regiões e Brasil (1974 a 1995)

2 Evolução do Índice de Produção Real, Brasil e São Paulo, 1986 a 1998 (base 1985=100) 


\section{LISTA DE QUADROS}

\section{Página}

1 Agrupamento de espécies nativas segundo o grau de informação disponivel, limitações e potencialidades.

2 Essências nativas consideradas aptas para o reflorestamento comercial.

3 Tipos de projetos de reflorestamento com essências nativas

4 Valor Atual (VA), Taxa Interna de Retorno (TIR) e variação percentual em relação à análise determinista, para os projetos $\mathrm{M}^{*}, \mathrm{P} 1^{*}$ e $\mathrm{Al}{ }^{*}$ (novos cenários) - situação em março de 1999

5 Taxa interna de retorno (TIR) média e desvio-padrão (DSP) para os projetos na agricultura e criação animal.

6 Definições das variáveis para a análise de risco dos projetos com pau-marfim.

7 Definições das variáveis para a análise de risco dos projetos com pinheiro-brasileiro.

8 Definições das variáveis para a análise de risco dos projetos com araruva. 


\section{LISTA DE TABELAS}

Página

1 Evolução da quantidade de trabalhos científicos publicados sobre essências nativas $(1953$ - 1997)...

2 Evolução da quantidade de trabalhos científicos publicados sobre as essências nativas mais pesquisadas $(1953-1981)$.

3 Quantidade de trabalhos científicos das essências nativas mais pesquisadas $(1982-1997)$

4 Evolução da quantidade de trabalhos científicos distribuídos por área de pesquisa e seus segmentos - 1953 a 1997.

5 Valores Atuais (VA) dos projetos de reflorestamento, em $\mathrm{R} \$ / \mathrm{ha}$, considerando custo de oportunidade do capital variando entre $6 \%$ e $20 \%$ ao ano - em março de 1999.

6 Relações Beneficio/Custo (RBC) dos projetos de reflorestamento considerando o custo de oportunidade do capital variando entre $6 \%$ e $20 \%$ ao ano - em março de 1999

7 Taxas Internas de Retorno (TIR) dos projetos de reflorestamento selecionados - em março de 1999.

8 Custos Totais Atualizados (CTA) dos projetos de reflorestamento, em $\mathrm{R} \$$ ha, considerando o custo de oportunidade do capital variando entre 6\% e 20\% ao ano - em março de 1999

9 Valores Esperados da Terra (VET) dos projetos de reflorestamento, em R \$ha, considerando o custo de oportunidade do capital variando entre $6 \%$ e $20 \%$ ao ano - em março de 1999.

10 Indicadores de rentabilidade considerando análise de risco para plantio de araruva com aquisição de mudas.

11 Indicadores de rentabilidade considerando análise de risco para plantio de araruva com doação de mudas pelo governo. 
12 Indicadores de rentabilidade considerando análise de risco para plantio de pau-marfim com aquisição de mudas.

13 Indicadores de rentabilidade considerando análise de risco para plantio de pau-marfim com doação de mudas pelo governo

14 Indicadores de rentabilidade considerando análise de risco para plantio de pinheiro-brasileiro com aquisição de mudas.

15 Indicadores de rentabilidade considerando análise de risco para plantio de pinheiro-brasileiro com doação de mudas pelo governo.

16 Fluxo de caixa do projeto de plantio de 1 hectare de pau-marfim, em terra comprada e com aquisição de mudas - valores expresso em reais $(\mathrm{R} \$)$ de março de 1999 - Projeto M1.

17 Fluxo de caixa do projeto de plantio de 1 hectare de pau-marfim, em terra arrendada e com aquisição de mudas - valores expressos em reais (R\$) de março de 1999 - Projeto M2.

18 Fluxo de caixa do projeto de plantio de 1 hectare de pau-marfim, sem considerar o custo da terra e com aquisição de mudas - valores expressos em reais (R\$) de março de 1999 - Projeto M3.

19 Fluxo de caixa do projeto de plantio de 1 hectare de pau-marfim, em terra comprada e com mudas doadas pelo governo - valores expressos em reais $(\mathrm{R} \$)$ de março de 1999 - Projeto M4.

20 Fluxo de caixa do projeto de plantio de 1 hectare de pau-marfim, em terra arrendada e com mudas doadas pelo governo - valores expressos em reais (R\$) de março de 1999 - Projeto M5.

21 Fluxo de caixa do projeto de plantio de 1 hectare de pau-marfim, sem considerar o custo da terra e com mudas doadas pelo governo - valores expressos em reais (R\$) de março de 1999 - Projeto M6.

22 Fluxo de caixa do projeto de plantio de 1 hectare de pinheiro-brasileiro, em terra comprada e com aquisição de mudas - valores expresso em reais $(\mathrm{R} \$)$ de março de 1999 - Projeto $P 1$ 
viii

23 Fluxo de caixa do projeto de plantio de 1 hectare de pinheiro-brasileiro, em terra arrendada e com aquisição de mudas - valores expressos em reais (R\$) de março de 1999 - Projeto P2.

24 Fluxo de caixa do projeto de plantio de 1 hectare de pinheiro-brasileiro, sem considerar o custo da terra e com aquisição de mudas - valores expressos em reais (R\$) de março de 1999 - Projeto P3

25 Fluxo de caixa do projeto de plantio de 1 hectare de pinheiro-brasileiro, em terra comprada e com mudas doadas pelo governo - valores expressos em reais (R\$) de março de 1999 - Projeto P4

26 Fluxo de caixa do projeto de plantio de 1 hectare de pinheiro-brasileiro, em terra arrendada e com mudas doadas pelo governo - valores expressos em reais (R\$) de março de 1999 - Projeto P5.

27 Fluxo de caixa do projeto de plantio de 1 hectare de pinheiro-brasileiro, sem considerar o custo da terra e com mudas doadas pelo governo valores expressos em reais (R\$) de março de 1999 - Projeto P6.. Fluxo de caixa do projeto de plantio de 1 hectare de araruva, em terra comprada e com aquisição de mudas - valores expressos em reais $(\mathrm{R} \$)$ de março de 1999 - Projeto A1

29 Fluxo de caixa do projeto de plantio de 1 hectare de araruva, em terra arrendada e com aquisição de mudas - valores expressos em reais $(\mathrm{R} \$)$ de março de 1999 - Projeto A2.

30 Fluxo de caixa do projeto de plantio de 1 hectare de araruva, sem considerar o custo da terra e com aquisição de mudas - valores expressos em reais (R\$) de março de 1999 - Projeto A3

31 Fluxo de caixa do projeto de plantio de 1 hectare de araruva, em terra comprada e com mudas doadas pelo governo - valores expressos em reais (R\$) de março de 1999 - Projeto A4

32 Fluxo de caixa do projeto de plantio de 1 hectare de araruva, em terra arrendada e com mudas doadas pelo governo - valores expressos em reais (R\$) de março de 1999 - Projeto A5

33 Fluxo de caixa do projeto de plantio de 1 hectare de araruva, sem considerar o custo da terra e com mudas doadas pelo governo valores expressos em reais (R\$) de março de 1999 - Projeto M6. 
34 Receitas das vendas dos subprodutos e produtos da exploração florestal de 1 ha de pau-marfim.

35 Custo de Implantação de 1 ha de pau-marfim com aquisição de mudas.

36 Custo de Manutenção no $1^{\underline{0}}$ ano de 1 ha plantado com pau-marfim

37 Custo Anual de Manutenção do $2^{0}$ ao $3^{0}$ ano de 1 ha plantado com pau-marfim.

38 Custo Anual de Manutenção do $4^{\underline{0}}$ ao $25^{0}$ ano de 1 ha plantado com pau-marfim.

39 Custo de Implantação de 1 ha de pau-marfim com mudas doadas pelo governo

40 Receitas das vendas dos subprodutos e produtos da exploração florestal de 1 ha plantado com pinheiro-brasileiro.

41 Custo de Implantação de 1 ha de pinheiro-brasileiro com aquisição de mudas.

42 Custo de Manutenção no $1^{\underline{0}}$ ano de 1 ha plantado com pinheirobrasileiro.

43 Custo Anual de Manutenção do $2^{\underline{0}}$ ao $3^{\underline{0}}$ ano de 1 ha plantado com pinheiro-brasileiro.

44 Custo Anual de Manutenção do $4^{0}$ ao $25^{0}$ ano de 1 ha plantado com pinheiro-brasileiro.

45 Custo de Implantação de 1 ha de pinheiro-brasileiro com mudas doadas pelo governo

46 Receitas das vendas dos subprodutos e produtos da exploração florestal de 1 ha plantado com araruva.

47 Custo de Implantação de 1 ha de araruva com aquisição de mudas.

48 Custo de Manutenção no $1^{0}$ ano de 1 ha plantado com araruva.

49 Custo Anual de Manutenção do $2^{\underline{0}}$ ao $3^{0}$ ano de 1 ha plantado com araruva. 
50 Custo Anual de Manutenção do $4^{0}$ ao $25^{0}$ ano de 1 ha plantado com araruva.

51 Custo de Implantação de 1 ha de araruva com mudas doadas pelo governo.

52 Receitas das Vendas de Subprodutos e Produtos da Exploração

Florestal de 1 ha de pau-marfim incorporando o efeito melhoramento florestal

53 Receitas das Vendas de Subprodutos e Produtos da Exploração

Florestal de 1 ha de pau-marfim incorporando o efeito do manejo sustentado

54 Receitas das Vendas de Subprodutos e Produtos da Exploração

Florestal de 1 ha de pau-marfim incorporando o efeito do frete

55 Receitas das Vendas de Subprodutos e Produtos da Exploração

Florestal de 1 ha de pau-marfim incorporando o efeito da heterogeneidade da população.

56 Receitas das Vendas de Subprodutos e Produtos da Exploração Florestal de 1 ha de pinheiro-brasileiro incorporando o efeito do ordenamento e melhoramento florestal.

57 Receitas das Vendas de Subprodutos e Produtos da Exploração Florestal de 1 ha de pinheiro-brasileiro incorporando o efeito do manejo sustentado

58 Receitas das Vendas de Subprodutos e Produtos da Exploração

Florestal de 1 ha de pinheiro-brasileiro incorporando o efeito do frete

59 Receitas das Vendas de Subprodutos e Produtos da Exploração

Florestal de 1 ha de pinheiro-brasileiro incorporando o efeito da heterogeneidade da população.

60 Receitas das Vendas de Subprodutos e Produtos da Exploração Florestal de 1 ha de araruva incorporando o efeito dos beneficios dasonômicos e do melhoramento florestal. 180 
61 Receitas das Vendas de Subprodutos e Produtos da Exploração Florestal de 1 ha de araruva incorporando o efeito do manejo sustentado.

62 Receitas das Vendas de Subprodutos e Produtos da Exploração Florestal de 1 ha de araruva incorporando o efeito do frete.

63 Receitas das Vendas de Subprodutos e Produtos da Exploração

Florestal de 1 ha de araruva incorporando o efeito da heterogeneidade da população. 
A VIABILIDADE ECONÔMICA DOS REFLORESTAMENTOS COM ESSÊNCIAS NATIVAS BRASILEIRAS PARA A PRODUÇÃO DE TORAS - O CASO DO ESTADO DE SÃO PAULO

\author{
Autor: JOSÉ ARIMATÉIA RABELO MACHADO \\ Orientador: Prof. CARLOS JOSÉ CAETANO BACHA
}

\title{
RESUMO
}

O presente trabalho analisa a viabilidade econômica dos reflorestamentos com essências nativas brasileiras destinadas a produção de toras, considerando como caso em estudo o Estado de São Paulo.

Inicialmente, analisa-se a produção e demanda de madeira em tora de essências nativas, as exigências de mercado por produtos certificados (nicho de mercado) e a legislação florestal brasileira, evidenciando como eles favorecem - criando demanda potencial - a implantação de reflorestamentos com essências nativas.

Constatada a existência desta demanda potencial, avalia-se as pesquisas com essas essências, evidenciando sua evolução e se há, atualmente, procedimentos técnicos adequados para o estabelecimento de reflorestamentos com essências nativas. Constatase que no Instituto Florestal de São Paulo existem experimentos com várias essências nativas e em vários estágios de crescimento. Dentre estes, três experimentos são considerados viáveis para reflorestamentos comerciais, com as seguintes espécies: Centrolobium tomentosum (araruva), Balfourodendron riedelianum (pau-marfim) e Araucaria angustifolia (pinheiro-brasileiro).

Em seguida, é realizada a análise de rentabilidade econômica desses projetos, em condições deterministas e de risco. Conclui-se que, do ponto de vista privado, os projetos de reflorestamento com essências nativas são viáveis economicamente.

Diante desse cenário, sugere-se novas linhas de pesquisa técnica capazes de gerar resultados que assegurem uma maior confiabilidade e ampliação na rentabilidade dos projetos de reflorestamento com essências nativas. 
ECONOMIC VIABILITY OF REFORESTING WITH BRAZILIAN NATIVE ESSENCES FOR LOGS PRODUCTION: THE CASE OF THE STATE OF SÃO PAULO

\author{
Author: JOSÉ ARIMATÉIA RABELO MACHADO \\ Advisor: Prof. CARLOS JOSÉ CAETANO BACHA
}

\begin{abstract}
\end{abstract}
The objective of the present work is to analyze the economic or financial viability of Brazilian native essences reforesting for log production, having the state of São Paulo as a study case.

Initially, we analyzed the log wood demand of native essences, market demand for certified products (market niche), and the Brazilian forest legislation, and highlighted the way they favor - by creating potential demand - reforesting implantation with native essences.

Once the existence of this potential demand was verified, we evaluated researches with these essences as well as their evolution, and the actual existence of appropriate technical procedures for the establishment of native essences reforesting. We concluded that, in the Forestry Institute of São Paulo, there are experiments with several native essences at several growth stages. Among these, three experiments are considered viable for commercial reforesting, with the following species: Centrolobium tomentosum, Balfourodendron riedelianum and_Araucaria angustifolia.

Afterwards, the economic profitability analyses of these projects were performed in risk and deterministical conditions. We concluded that, from the private point of view, the reforesting projects with native essences are economically viable.

In this perspective we suggest, new lines of technical research which are able to generate results that would ensure a greater reliability and an increase in profitability of native essences reforesting projects. 


\section{INTRODUÇÃO}

Este trabalho analisa a viabilidade econômica dos reflorestamentos com essências nativas do Brasil visando à produção de toras a serem utilizadas na indústria de desdobro mecânico das mesmas. Para tanto, toma-se como caso em estudo o Estado de São Paulo, o qual possui vários experimentos neste tipo de reflorestamento.

No texto, utilizam-se os termos essência nativa ou espécie florestal nativa como sinônimos, ou seja, o termo essência nativa é usado no sentido de espécie (falando-se das árvores de uma floresta) que é natural do Brasil (aquelas trazidas de outros países pelo Homem não são consideradas).

Um importante marco nos estudos sobre reflorestamentos no Brasil se deve à atuação da Companhia Paulista de Estradas de Ferro no início do século. Em 1904, Edmundo Navarro de Andrade - designado por esta Companhia - comparou o desenvolvimento de várias essências de valor econômico e concluiu que o eucalipto era a melhor delas para os fins desejados. Com isso, intensificaram-se os estudos sobre a cultura racional dessa essência exótica. Esse foi um dos motivos que estimulou a formação de eucaliptais pelos agricultores no Estado de São Paulo na primeira metade do século XX (Gurgel Filho, 1962).

Outra essência exótica introduzida com sucesso no Brasil foi o pinus. De acordo com Prates (1979), a partir do final da década de cinqüenta, a intensa diminuição dos pinheirais na região Sul motivou a expansão da cultura do pinus como madeira alternativa.

A maior expansão do plantio dessas espécies florestais exóticas, porém, só ocorreu no período dos incentivos fiscais ao florestamento/reflorestamento ${ }^{1}$ (1966 a 1988).

Em sua maior parte, a silvicultura comercial se expandiu baseada no plantio de essências exóticas (especialmente, o eucalipto e o pinus). O interesse pelas espécies

\footnotetext{
${ }^{1}$ Adaptando a classificação de Leite (1979), a expansão da silvicultura brasileira pode ser dividida em três etapas: o período que vai de 1500 a 1965; depois o período de vigência dos incentivos fiscais ao reflorestamento/florestamento (1966 a 1988); e, a partir de 1989, inicia-se o período pós-incentivos fiscais ao reflorestamento/florestamento.
} 
nativas ganhou impulso a partir da década de setenta. Em 1972, a realização da Conferência de Estocolmo foi um alerta para a humanidade sobre a degradação ambiental. Com isso, intensificaram-se as pesquisas com as essências nativas brasileiras, ainda que estas pesquisas tivessem mais motivação preservacionista do que comercial.

\subsection{Delimitação do Problema em Estudo}

O mercado de madeiras de essências nativas brasileiras existe desde a descoberta do Brasil pelos portugueses. A abundância deste recurso natural ao longo do território tem sido fato importante para que a oferta deste se baseie na exploração de florestas nativas. Contudo, a exploração tem tido intensidade diferente entre as regiões do território brasileiro, o que tem provocado um desequilibrio entre oferta e demanda em nivel regional. Por outro lado, os reflorestamentos implantados em determinadas regiões, a fim de suprir a escassez de madeira, têm se baseado nas culturas das essências exóticas pinus e eucalipto, prioritariamente. Há assim, uma demanda potencial por madeira oriunda de reflorestamentos com essências nativas.

Neste contexto, é importante a análise da viabilidade econômica da implantação de reflorestamentos com espécies florestais nativas a fim de complementar ou substituir a oferta. de toras oriundas das matas remanescentes. Para tanto, alguns aspectos necessitam ser melhor avaliados, dentre os quais: o valor atribuído à cobertura florestal original, o papel da legislação florestal e do mercado e o nivel de conhecimento acumulado sobre o reflorestamento com essências nativas.

O valor atribuido pela sociedade às florestas nativas brasileiras não é o mesmo ao longo do tempo. Na verdade, o papel desempenhado por estas florestas pode ser dividido em duas fases. A primeira durou séculos e caracterizou-se pela preocupação do ser humano em extrair o máximo de produtos da floresta e transformá-la em pastagens, áreas com lavoura ou em áreas urbanas. A segunda fase é a qual se vive nas últimas décadas e caracteriza-se pela preocupação com os beneficios não tão diretos ou visiveis proporcionados pela conservação da cobertura florestal nativa. 
Myers (1990), ao comentar a respeito das inúmeras conseqüências provocadas pelo desmatamento para o bem-estar humano, cita o papel de regulador dos fluxos de água por parte das florestas tropicais. Além disso, Hosokawa (1987) lembra que as florestas protegem o solo contra a erosão hídrica e eólica, contra a radioatividade e ruído, colaborando não só no equilíbrio atmosférico, mas inclusive do micro clima, etc. Ultimamente, dois benefícios têm merecido atenção especial: o controle do efeito estufa e a conservação da biodiversidade.

Devido aos beneficios indiretos que gera, a sociedade mudou o tipo de importância dada à cobertura florestal nativa. Mesmo com a existência de novos desmatamentos para a produção de madeira, ocupação do solo pela agropecuária ou expansão urbana, as pessoas estão ficando mais conscientes das desvantagens deste processo. Com isso, a sociedade procura se organizar de maneira a evitar prejuizos irrecuperáveis. Uma das formas se dá através da criação de uma legislação mais rígida.

A atual legislação florestal brasileira é composta pela Lei $n^{0} 4.771$, de 15/09/65 (Código Florestal), e legislação complementar. Em linhas gerais, a legislação procura manter a porcentagem, considerada como mínima, da cobertura nativa original, da seguinte forma: estabelecendo quais áreas são de preservação permanente, criando unidades de conservação, limitando o uso de certas áreas (por exemplo, áreas muito íngremes), criando a reserva legal nas áreas privadas, estabelecendo normas para a exploração, criando obrigações para os consumidores e normatizando a fiscalização e as punições aos infratores.

Outra forma de manifestação da sociedade é através do mercado. Uma população consciente dos maleficios provocados pela exploração predatória das florestas pode exigir um produto que seja oriundo de áreas florestais manejadas de forma sustentada. Assim, os produtos oriundos da floresta passam a ser discriminados quanto ao seu manejo e a serem comercializados com preços diferenciados dos demais.

À medida que a legislação e o mercado passem a ser mais eficazes, a oferta de toras oriundas do extrativismo tende a ser cada vez mais restrita. Em regiões com pequenos remanescentes de florestas nativas, como o Estado de São Paulo, passa a ser extremamente 
dificil explorar tais florestas. Daí a recuperação de áreas degradadas em obediência a legislação da reserva florestal legal.

Neste quadro de pressões cada vez maiores contra o desmatamento das áreas com vegetação remanescente, o plantio de florestas com essências nativas torna-se uma alternativa para a oferta de madeira destas espécies. Antigamente, a abundância de florestas nativas em várias regiões do país desincentivava este tipo de reflorestamento. Atualmente, esta possibilidade merece ser melhor estudada.

A pesquisa com essas espécies se intensificou a partir da década de oitenta e, com isso, o conhecimento científico e técnico tem se acumulado. Segundo Antonangelo (1996), a evolução da quantidade de trabalhos cientificos publicados no Brasil tem sido diferente para as várias espécies florestais. As espécies exóticas (Pinus e Eucalipto) têm sido as mais pesquisadas. As pesquisas com espécies nativas (com exceção das espécies do gênero Araucária que o autor destacou em separado) têm aumentado a sua participação a partir da década de oitenta. A maior preocupação com questões ambientais pode ser apontada como uma das causas do crescimento de estudos com espécies florestais nativas.

Há, atualmente, um grande volume de pesquisas com essências nativas e vários reflorestamentos com algumas delas. Não obstante, não foi ainda realizado um trabalho que avalie o "estado da arte" com essas pesquisas e avalie, economicamente, a viabilidade de reflorestamentos com essências nativas, em especial as que geram toras para o processamento mecânico.

\subsection{Objetivos}

O objetivo geral deste trabalho é analisar a viabilidade econômica de reflorestamentos com essências nativas brasileiras destinadas a produção de toras a serem utilizadas na indústria de desdobro mecânico das mesmas. Para tanto, toma-se como caso em estudo o Estado de São Paulo. Os objetivos específicos são:

- analisar os fatores que geram uma demanda potencial por reflorestamentos com essências nativas no Brasil; 
- analisar os fatores que geram uma demanda potencial por reflorestamentos com essências nativas no Brasil;

- analisar a evolução da pesquisa sobre reflorestamentos com essências nativas e delimitar o atual "estado da arte";

- delimitar possíveis projetos de reflorestamentos com essências nativas destinados a produção de toras e para os quais há informações técnicas e econômicas, no Estado de São Paulo; e,

- calcular a rentabilidade destes projetos de reflorestamento, em condições deterministas e de riscos.

A escolha do Estado de São Paulo para o caso em estudo se deve a alguns aspectos. Primeiro, a cobertura florestal remanescente neste estado se encontra abaixo das recomendações internacionais. Segundo, trata-se de um dos grandes centros consumidores de madeira de espécies nativas no Brasil. Terceiro, a atuação do Serviço Público na área florestal tem sido importante para o desenvolvimento da silvicultura brasileira. E, por fim, mas não menos importante, existe acúmulo de informações acessíveis sobre reflorestamentos experimentais com espécies florestais nativas, com um longo período de observação.

\subsection{Organização do Trabalho}

Esta dissertação está organizada em seis capítulos, incluindo esta introdução. No capítulo 2 são apresentados os instrumentos de incentivo ao reflorestamento e/ou controle do desmatamento. Com base nesses instrumentos é realizada, no capítulo 3, a análise dos fatores que geram demanda potencial por reflorestamentos com essências nativas no Brasil. No capítulo 4 analisa-se a evolução das pesquisas com espécies nativas brasileiras (item 4.1) e a experiência do Instituto Florestal no Estado de São Paulo (item 4.2). No capítulo 5 são apresentados os aspectos gerais e os critérios para avaliação dos projetos (itens 5.1 e 5.2), suas estimativas para os projetos selecionados (itens 5.3), os impactos de novos cenários nas estimativas (item 5.4) e os resultados da análise de risco com simulações de Monte Carlo (item 5.5). E, no capítulo 6, são apresentadas as conclusões. 


\section{INSTRUMENTOS DE INCENTIVO AO REFLORESTAMENTO E/OU CONTROLE DO DESMATAMENTO}

O incentivo ao reflorestamento e/ou controle do desmatamento pode ser obtido pelo uso de instrumentos de política pública ou por exigências de mercado. No primeiro caso, o poder público utiliza-se de instrumentos de política econômica para atingir tal fim. Já no outro caso, o próprio mercado pode criar mecanismos para diferenciar o produto segundo sua origem ou modo de produção.

O item 2.1 resume a adaptação feita por Bacha (1998) sobre instrumentos econômicos para controle do uso dos recursos florestais. Neste sentido, o poder público pode utilizar-se de instrumentos baseados no mercado (IBM) ou os instrumentos de comando e controle (ICC). Os IBM são os seguintes: subsidio, tributação e leilão de direito de exploração florestal. Dentre os ICC, os principais são: autorização prévia para o desmatamento, zoneamento agro-ecológico e a reposição florestal.

No item 2.2 analisa-se como o próprio mercado pode criar instrumentos para alterar o preço de determinado produto. Especificamente para os produtos florestais, destaca-se o papel do "Selo Verde" tanto no âmbito nacional como internacional. 
2.1 Instrumentos do Poder Público para Incentivo ao Reflorestamento e/ou Manutenção das Florestas Nativas

$\mathrm{Na}$ introdução deste trabalho foi destacado o crescimento da importância dada pela sociedade aos beneficios indiretos das florestas nativas. Estes beneficios podem ser entendidos como externalidades positivas, ou seja, a manutenção de uma mata nativa, por um agente econômico, afeta positivamente a utilidade ou a lucratividade de outros agentes econômicos.

Uma característica dessas externalidades é que elas não possuem preço por não serem transacionadas no mercado. Uma das formas de contornar esta situação seria atribuir um preço indireto às matas nativas. O poder público pode cumprir esta função na medida em que cria instrumentos para este fim, procurando controlar o desmatamento e/ou incentivar o reflorestamento. Estes instrumentos podem ser divididos em dois grupos: instrumentos baseados no mercado (IBM) e os instrumentos de comando e controle (ICC).

\subsubsection{Instrumentos Baseados no Mercado (IBM)}

Os instrumentos baseados no mercado procuram motivar os agentes econômicos a realizar o reflorestamento e/ou manter a floresta nativa. Isto é feito através da alteração das receitas e custos que os agentes econômicos têm ao comparar práticas florestais alternativas. Dentre os IBM mais utilizados destacam-se: os subsídios, a tributação e os leilões de direito de exploração florestal.

Os subsidios podem ser concedidos tanto para incentivar o reflorestamento quanto para preservar matas nativas. No caso do reflorestamento, a idéia é fornecer parte dos recursos monetários necessários ao investimento inicial ou doar insumos ou serviços que diminuem o custo de implantação das florestas. Seja qual for a situação, os subsídios podem ser concedidos através de: crédito subsidiado à formação, implantação ou manutenção de florestas; doação de insumos e assistência técnica aos produtores; ou ainda, por beneficios fiscais (incentivos e isenções fiscais).

Os incentivos fiscais são, na prática, o retorno ao contribuinte de parcela paga de 
determinados impostos. No entanto, são estabelecidas regras para que estes recursos sejam investidos para se alcançar certos objetivos. Por exemplo, se o objetivo do governo é promover o desenvolvimento de uma atividade ou região, o fisco pode permitir que parcela do imposto de renda pago pela pessoa física e/ou jurídica seja destinada a projetos de determinada atividade ou região. Trata-se, portanto, de uma doação de capital. Por outro lado, a isenção fiscal pode servir para aumentar a rentabilidade de uma atividade. Neste caso, ela pode atingir determinadas regiões, pela isenção de impostos indiretos (como o ICMS), ou o país no todo, pelas isenções de impostos patrimoniais (como o ITR) e imposto de renda sobre o lucro da atividade.

Os subsídios também podem ser usados para se controlar o desmatamento. Neste caso, a idéia é conceder uma compensação monetária aos proprietários que conservem áreas florestais que geram beneficios sociais. A concessão de subsídios pode ser através do pagamento direto de renda monetária ao produtor rural, pela criação de outros bens e serviços de apoio ao produtor ou pela isenção da cobrança de impostos.

No caso do pagamento de renda monetária, o subsídio deve corresponder ao custo de oportunidade equivalente a renda agropecuária que poderia ser obtida na área conservada com mata nativa. A criação de bens e serviços adicionais caracteriza-se como um salário indireto pago aos produtores por conservar áreas maiores com matas nativas. Já a isenção de impostos poderia corresponder ao abatimento destes sobre as áreas de preservação permanente ou sob a forma de reserva legal.

Outro IBM utilizado pelo poder público é a tributação. Através da cobrança de um valor fixo ou ad valorem por produto florestal, elaborado ou consumido a partir de matas nativas, cria-se um desestímulo ao desmatamento. Além disso, esta tributação muda o preço relativo em favor dos produtos florestais de áreas plantadas, em relação aos de mata nativa, estimulando a ampliação do reflorestamento.

Por fim, o leilão de direito de exploração florestal é um IBM adequado às propriedades públicas, como é o caso dos leilões de direitos de exploração das Florestas Nacionais (FLONAS). 


\subsubsection{Instrumentos de Comando e Controle}

O controle do desmatamento pode ser feito pelo poder público não só através de mecanismos de incentivo econômico ao mercado mas, também, pelo seu poder regulatório, através dos Instrumentos de Comando e Controle (ICC). O Estado, imbuído do poder autoritário que lhe cabe, decide o que pode ser feito, quando, onde e de que forma. Destacam-se como os principais ICC: a autorização prévia para o desmatamento, a reposição florestal e o zoneamento agro-ecológico. A autorização prévia para o desmatamento, concedida pela Autoridade Florestal, visa controlar a retirada da cobertura florestal das áreas que são permitidas de ser exploradas. Já a reposição florestal é um instrumento usado pelo Poder Público para obrigar os consumidores de matéria-prima florestal a repor, em número equivalente de árvores, o seu consumo de madeira ou carvão vegetal. O objetivo é procurar garantir uma oferta sustentável desses produtos ao longo do tempo. Já o zoneamento agroecológico procura definir quais as áreas são passiveis para a exploração agropecuária e quais devem ser preservadas ou conservadas com vegetação nativa. Assim, o Estado, através de atos normativos, regula o tipo de exploração permitida, buscando o bem-estar social.

À medida que os ICC são eficazes na redução do desmatamento haverá redução na oferta de madeira nativa e, com isso, elevação do preço de sua madeira em relação ao de mata plantada. Isto se transforma em incentivo ao reflorestamento.

\subsection{Instrumentos Privados para Incentivo ao Reflorestamento e/ou Manutenção das Florestas Nativas}

O mercado, a despeito dos instrumentos econômicos adotados pelo Estado, também pode criar as suas próprias exigências. A busca de produtos ambientalmente corretos, principalmente em nível de mercado internacional, é a tendência mais recente. A adoção do "selo verde" foi uma forma encontrada para diferenciar um produto florestal quanto a sua origem e manejo. 
O selo verde procura motivar os consumidores a criar uma demanda especifica. Segundo alguns autores (como Viana, 1996; Barbosa, 1995), os consumidores europeus e americanos estariam dispostos a pagar um diferencial de $5 \%$ a $15 \%$ sobre o preço de uma mercadoria de madeira com selo verde em relação a produto similar sem este certificado.

De acordo com Moncada (1995), a certificação de madeiras tropicais surge em resposta a distorções no mercado, entre as quais: proibições do livre comércio por parte dos governos e os boicotes dos consumidores. Assim, esse é mais um instrumento de controle do desmatamento. Para Tomaselli (1994), o maior enfoque na atualidade é com respeito a madeiras tropicais, mas a tendência é de que a médio prazo sejam também consideradas as madeiras temperadas e boreais.

A certificação de produtos florestais, pela adoção de técnicas de manejo sustentável, também é aplicada às áreas reflorestadas. Conforme Ponce(1994), a tendência mundial é a produção de madeira a partir de florestas plantadas ou regeneradas. No caso da Floresta Amazônica Brasileira, as condições naturais adversas dificultam e encarecem as medidas necessárias para uma exploração sustentada.

Portanto, não só o poder público mas, também, o setor privado pode se utilizar de instrumentos com os quais afetem o mercado de produtos florestais.

Em suma, os instrumentos de incentivo ao reflorestamento são divididos em instrumentos de política pública e instrumentos privados. No capítulo 3 são analisados os nichos de mercado e o papel da legislação como fatores criadores de demanda potencial por madeira de reflorestamento com nativas. No capítulo 4 são avaliados os resultados das pesquisas com essências nativas e identificados os projetos factiveis. Esses, foram, em grande parte, conduzidos por órgãos públicos de pesquisa, os quais fornecem, gratuitamente ou a preços subsidiados a tecnologia e as mudas. No capitulo 5 , será avaliada a importância da doação de mudas na determinação da rentabilidade econômica de projetos de reflorestamento com essências nativas. 


\section{PRODUÇÃO E DEMANDA DE MADEIRAS DE ESSÊNCIAS NATIVAS E A LEGISLAÇÃO FLORESTAL BRASILEIRA}

O propósito deste capítulo é analisar a produção e demanda de madeiras de essências nativas, as exigências do mercado por produtos certificados de madeira e a legislação florestal brasileira, evidenciando como eles favorecem - criando demanda potencial - a implantação de reflorestamentos com essências nativas.

No item 3.1 é feita a caracterização da produção e do consumo de madeira nativa no Brasil, dando ênfase à capacidade de exploração dos remanescentes florestais existentes. Procura-se evidenciar que o processo atual de extração florestal não garante produção sustentada de madeiras nativas, o que gera a demanda potencial por madeira oriunda de reflorestamentos com essências nativas.

Em seguida, no item 3.2, discute-se como as preocupações das sociedades nacional e internacional com as questões ambientais têm influenciado a produção brasileira de madeiras de espécies nativas. Pode-se constatar que alguns agentes que operam nesse mercado têm procurado criar instrumentos que auxiliem na diferenciação de produtos oriundos do manejo sustentado. Alternativamente a este, surgem os reflorestamentos com espécies nativas para atender esse nicho de mercado.

Por fim, no item 3.3, é feita uma explanação de como a legislação florestal brasileira delimita o uso de áreas com florestas nativas quanto ao grau de exploração permitido e cria uma demanda institucional por reflorestamento com essências nativas.

Os itens 3.2 e 3.3 mostram a atuação dos instrumentos privados e públicos, respectivamente, afetando o reflorestamento no Brasil. 


\subsection{Produção e Demanda de Madeira em Tora de Nativas no Brasil}

Inicialmente, é analisada a evolução da produção brasileira de madeiras em toras de essências nativas, observando a mudança geográfica dessa produção. Em seguida (subitem 3.1.2), avalia-se o potencial de exploração dos remanescentes florestais nativos, principalmente na Amazônia brasileira. No subitem 3.1.3, analisa-se o consumo de madeira nativa no Brasil e no Estado de São Paulo.

\subsubsection{Evolução da Produção de Toras Nativas no Brasil e em suas Regiões}

A produção de madeiras de espécies florestais nativas existe no Brasil desde a sua descoberta pelos portugueses. Primeiro foi a Mata Atlântica, depois os pinheirais da região Sul e, atualmente, a Amazônia Brasileira é alvo da exploração predatória. Apesar da história brasileira não mencionar um "ciclo econômico das madeiras de essências nativas", é irrefutável a importância dessas para a economia brasileira. No entanto, a forma de exploração tem limitado o potencial de oferta de madeiras nativas.

$\mathrm{Na}$ figura 1, observa-se que a produção de toras de essências nativas no Brasil apresentou uma tendência de crescimento nas últimas décadas, impulsionada pela expansão da produção na região Norte. De 1974 a 1990 houve forte crescimento da produção nacional de toras de madeira de essências nativas, que passou de 25,96 a 97,51 milhões de metros cúbicos, respectivamente.

Nas últimas três décadas, tem ocorrido o deslocamento da produção da região Sul para o norte do país. Em 1974 a região Sul era responsável por $50,65 \%$ da produção nacional de madeiras em tora e a região Norte por 13,12\%. Em 1995 essas importâncias foram 7,06\% e 76,03\%, respectivamente. A região Sul teve, inclusive, redução na produção fisica (figura 1), advinda da exploração predatória das florestas ou de sua substituição por outras atividades.

$\mathrm{Na}$ década de 90 , cerca de $3 / 4$ a produção brasileira de madeira de essências nativas tem sido originária da região Norte. Oscilações na produção desta região vêm determinando 
as oscilações na produção nacional (figura 1). As perguntas que se colocam são: Qual a potencialidade de produção da região? Como manter sustentável essa produção?

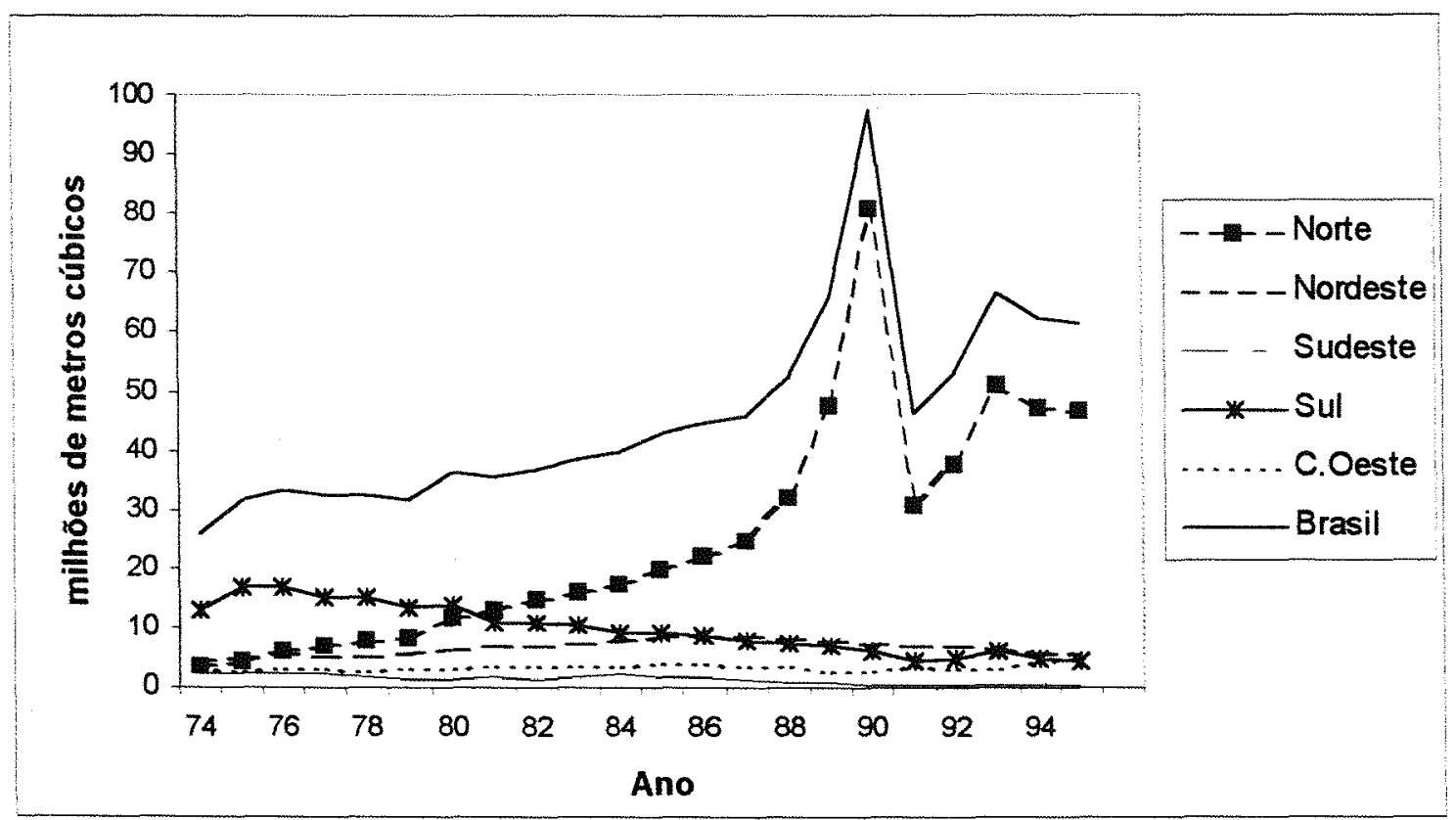

Figura 1 - Produção de madeira em tora de espécies florestais nativas por grandes regiões e Brasil (1974 a 1995)

Fonte: Anuário Estatístico do Brasil (1977 a 1997)

\subsubsection{Potencialidade das Reservas Remanescentes}

Atualmente, mesmo após intensa exploração, as reservas florestais nativas ainda são muito grandes, porém, mal distribuídas entre as regiões brasileiras por terem sido exploradas com intensidades diferentes. Segundo Siqueira (1994), nas regiões Nordeste e Sudeste essas matas são pequenas e, na região Sul, elas são insuficientes para atender à demanda regional futura. Já nas regiões Centro-Oeste e Norte, nas áreas de floresta amazônica, existe um enorme potencial que poderia até mesmo atender à demanda interna.

A região denominada de "Amazônia Legal" abrange aproximadamente 506 milhões de hectares ( $60 \%$ da superficie brasileira), dos quais 385 milhões de hectares são cobertos com florestas das quais, por sua vez, 280 milhões de hectares são de floresta tropical densa. 
É a maior reserva florestal tropical do mundo, com um volume comercial de madeira em pé estimado, em 1988, em 50 bilhões de metros cúbicos (Carvalho,1988). Conforme Siqueira (1994), em 1992, esse volume seria de 45 bilhões de metros cúbicos distribuídos em $89 \%$ da área coberta com floresta primitiva. Observa-se que, apesar de enorme, a exploração da Floresta Amazônica está sendo feita de forma a reduzir o seu potencial.

Por outro lado, o volume de madeira por área é variável dentro da região amazônica (Reis, 1989). Na média entre as áreas, estima-se um volume de $155 \mathrm{~m}^{3}$ de madeira por hectare. Mesmo diante desse potencial, o volume de toras removido por hectare pelas serrarias é bem menor: $11 \mathrm{~m}^{3}$ segundo Mercado \& Campagnani (1988), $25 \mathrm{~m}^{3}$ segundo Reis (1989), $40 \mathrm{~m}^{3}$ segundo Siqueira (1994) e $45 \mathrm{~m}^{3}$ segundo Yared et al. (1988). As diferenças de estimativas das reservas, do potencial de cada área e do volume explorado nestas podem ser atribuídas à extensão da região considerada e à diversidade de espécies.

Infelizmente, as empresas que se estabeleceram na região amazônica mantiveram a forma de exploração predatória de florestas. Conforme Carvalho (1988), a exploração é empírica, em termos de desordenado extrativismo, por processos rudimentares e primitivos, sem organização e sem qualquer noção de manejo sustentado. Segundo Reis (1989), para se entender os problemas relacionados com o suprimento de matéria-prima para as indústrias é importante saber que existem dois tipos de florestas na região amazônica: a de terra firme e a de várzea.

A floresta de terra firme representa $90 \%$ de toda a floresta amazônica, havendo grande variação na composição de espécies de uma área para outra. Já a floresta de várzea é menos heterogênea que a anterior. Alguns inventários florestais indicam haver mais de cem espécies madeireiras por hectare, mas apenas algumas são utilizadas. Com isso, várias áreas têm o valor econômico limitado e as que são exploradas atingem mais rápido a exaustão. Para aumentar o espectro de espécies de valor econômico seria necessário: otimizar o valor da madeira, agrupá-las em classes e promover a mistura de espécies para uso industrial integrado.

Outra característica que distingue esses dois tipos de floresta é a sazonalidade da 
exploração. Na floresta de terra firme essa é normalmente realizada na época da seca (outubro a fevereiro), pois as estradas da região ficam em precárias condições de tráfego com as chuvas. Na floresta de várzea a exploração é mais intensa no período das chuvas (março a setembro) devido a facilidade para o transporte das toras nos igarapés e rios. Conforme Reis (1989), na região amazônica 68\% das toras são transportadas em jangadas, $5 \%$ por rebocadores e barcaças e $27 \%$ por caminhões. Embora esteja se tornando uma floresta empobrecida, a floresta de várzea ainda é responsável pelo suprimento de grande parte da madeira para as indústrias.

Por outro lado, a produção de madeiras não está relacionada somente com as características fisicas e climáticas da região. A exploração, corte e remoção das toras é feita por extratores autônomos, com emprego de métodos rudimentares, que resultam em baixo rendimento, fornecimento irregular, falta de uniformidade do tipo de produto e grande desperdício de madeira. Somados esses fatores, o resultado é uma distância cada vez maior da fonte de produção da matéria-prima às indústrias. Assim, o custo de transporte aumenta e passa a ser uma variável extremamente importante para a viabilização econômica do empreendimento florestal-industrial.

A atual forma de exploração das florestas na região amazônica gera não só desperdícios, mas também uma floresta degradada, de baixo valor ecológico e econômico. Segundo Reis (1989), estima-se que nas porções mais ricas da Floresta Amazônica, com volume total de 230 a $280 \mathrm{~m}^{3}$ de biomassa florestal por hectare, apenas $10 \%$ deste volume chega às serrarias. Dos $90 \%$ restantes, $49 \%$ é destinado a lenha e o resto é deixado na floresta. Essa forma de exploração está levando à redução das áreas de floresta existentes. No entanto, esta situação poderia ser diferente se a exploração fosse sustentada.

Conforme Siqueira (1994), para se ter uma produção sustentada na região amazônica necessita-se de menos de $15 \%$ dos 45 bilhões de $\mathrm{m}^{3}$ de reservas existentes. Para Yared et al.(1988), considerando o volume de produção em 1988, é possível garantir um suprimento contínuo de matéria-prima utilizando-se cerca de 3,0\% da floresta densa amazônica. Para isso, seria necessário manejar 7,8 milhões de hectares, com ciclos de corte de 30 anos. Neste 
caso foi considerado um volume comercial de $45 \mathrm{~m}^{3}$ por hectare e uma produção anual de 11,7 milhões de $\mathrm{m}^{3}$ de toras. O volume produzido em 1995, guardadas as devidas proporções com 1988, deveria implicar no uso de $12 \%$ da floresta densa amazônica.

Segundo Yared et al.(1988), o manejo sustentado apresenta duas tendências. A primeira, iniciada na década de 50 pelos técnicos da $\mathrm{FAO}$, procura simplificar a floresta natural para aumentar a produtividade, porém, a floresta torna-se mais vulnerável ao ataque de pragas e doenças. A segunda, mais recente, procura manter a estrutura original da floresta, com retiradas moderadas de madeira e em ciclos mais curtos (sistema policíclico). Apesar da baixa produtividade madeireira, a floresta permanece exercendo suas funções ecológicas e socio-econômicas. Em ambos os casos, procura-se manejar a floresta sem que haja a necessidade de reduzi-la, o que implica maiores custos de exploração.

Conforme Tomaselli (1994), estudos preliminares sobre a adoção do manejo sustentado na floresta amazônica indicam que haveria um acréscimo médio de aproximadamente US $\$ 15,00$ (podendo chegar a mais de US\$ 30,00, dependendo das condições) por metro cúbico de tora produzido. Por outro lado, há que se considerar as vantagens desse sistema. De acordo com Reis (1989), o manejo sustentado de florestas nos arredores das serrarias minimiza os problemas de suprimento da matéria-prima, custos de transporte e outros problemas da indústria. Seja qual for a relação beneficio/custo para a adoção desse sistema, as pressões da sociedade para adotá-lo são cada vez maiores.

\subsubsection{Consumo de Madeira Nativa}

A abundância de matas nativas no território brasileiro fez com que a indústria madeireira se instalasse nos mais diversos locais. Até o final da década de sessenta, devido a uma conjunção de diversos fatores, essa atividade foi mais vigorosa na região Sul. $O$ esgotamento das reservas de araucária e de folhosas nobres, porém, levaram as indústrias a seguirem dois caminhos: implantar maciços florestais para suprir a demanda futura ou procurar uma nova fonte de madeiras de essências nativas. Os incentivos fiscais contribuiram de forma significativa para os reflorestamentos, principalmente com as espécies exóticas 
pinus e eucalipto. Por outro lado, várias empresas que sobreviveram na região Sul, São Paulo, Espírito Santo e Minas Gerais preferiram estabelecer vínculos com a exploração das matas nativas da região Norte.

As toras de madeiras nativas oriundas desta exploração são consumidas pelo setor industrial brasileiro de madeiras duras tropicais, que se subdivide nas seguintes indústrias: madeira serrada, madeira compensada, madeira laminada e móveis. Em 1987, a maioria das madeiras duras era processada em poucas empresas de grande e médio porte e em um grande número de pequenas empresas dispersas pela região amazônica (Reis, 1989). A indústria de madeira serrada concentrava-se principalmente nos estados do Pará, Rondônia e Mato Grosso, sendo os dois primeiros os principais produtores. Havia na região amazônica 2.892 serrarias das quais 2.078 eram pequenas (até $5.000 \mathrm{~m}^{3}$ por ano), 654 médias (até $10.000 \mathrm{~m}^{3}$ por ano) e 160 grandes (acima de $10.000 \mathrm{~m}^{3}$ por ano).

A indústria de madeira compensada compreendia 250 empresas no Brasil, localizadas principalmente nos estados das regiões Sudeste e Sul sendo que na região amazônica existiam apenas 10 empresas. Estas, por sua vez, utilizavam-se principalmente de toras da região amazônica e em menor escala das oriundas dos estados da Bahia e Espirito Santo.

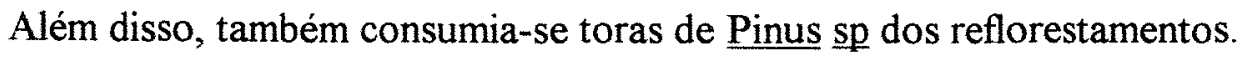

Já a indústria de madeira laminada se concentrava nos mesmos estados que as serrarias e as empresas eram de pequeno porte. A madeira utilizada era de alta qualidade, sendo que a virola e a muiratinga eram as principais espécies para a fabricação do laminado tipo rotatório. Para o laminado tipo sliced-veneer as principais espécies utilizadas eram o mogno, cerejeira, cedro, sucupira e louro preto.

As empresas da indústria moveleira estavam concentradas nas regiões Centro-Oeste, Sudeste e Sul. Na região Nordeste e Norte haviam fábricas de pequeno porte dispersas nestas regiões. A matéria-prima era originada da Amazônia e dos estados da Bahia e Espírito Santo.

Segundo o último Censo Industrial, realizado pelo Instituto Brasileiro de Geografia e Estatística (IBGE), em 1985 haviam 17.129 estabelecimentos pertencentes à indústria da 
madeira no Brasil, destes 2.209 se localizavam no Estado de São Paulo. Em termos de pessoal ocupado total e valor bruto da produção industrial, o Estado de São Paulo representava $13,09 \%$ e 18,85\% do total nacional, respectivamente. Após 1985, houve uma redução do valor da produção real tanto em nível de Brasil quanto de Estado de São Paulo (veja figura 2). De qualquer forma, ressalta-se novamente a existência da indústria da madeira no Estado de São Paulo, independente do tipo de espécies utilizadas como matériaprima.

Segundo Smeraldi \& Veríssimo (1999), apesar da Amazônia ser a principal região produtora de madeiras tropicais no Brasil, apenas $10 \%$ da produção é consumida na região. Para o mercado externo são exportados $14 \%$ da produção. Somente o estado de São Paulo consome $20 \%$, e os $56 \%$ restantes destinam-se para as outras regiões brasileiras.

De acordo com Reis (1989), as toras de maior valor são enviadas para as regiões Sul, Centro-Oeste e Nordeste. Mas, a maior parcela da produção deixa a região amazônica na forma de madeira serrada, laminada ou compensada.

O mercado local na Amazônia é abastecido normalmente pelas serrarias de pequeno porte o que, devido ao seu menor grau de exigência, permite a utilização de uma variedade maior de espécies de madeiras de qualidade inferior. Já o mercado nacional é abastecido por serrarias de grande e médio portes. Normalmente, os produtos de maior valor destinam-se ao mercado nacional e internacional, sendo que o mercado interno serve de teste para os produtos exportados. Devido as elevadas despesas de frete, as regiões Sul e Sudeste consomem espécies mais conhecidas e de maior valor relativo, ao contrário da região Nordeste (Reis, 1989).

Como se vê, apesar da exploração de espécies nativas se concentrar na região Norte, muitas das empresas da indústria de madeira dura tropical se localizam em outras regiões do país. Além disso, deve-se destacar que em algumas regiões - como o Estado de São Paulo - a indústria de serrarias não se extinguiu, mas sim, se adaptou às novas condições de oferta de matéria-prima oriunda dos reflorestamentos com Pinus e Eucalipto. 


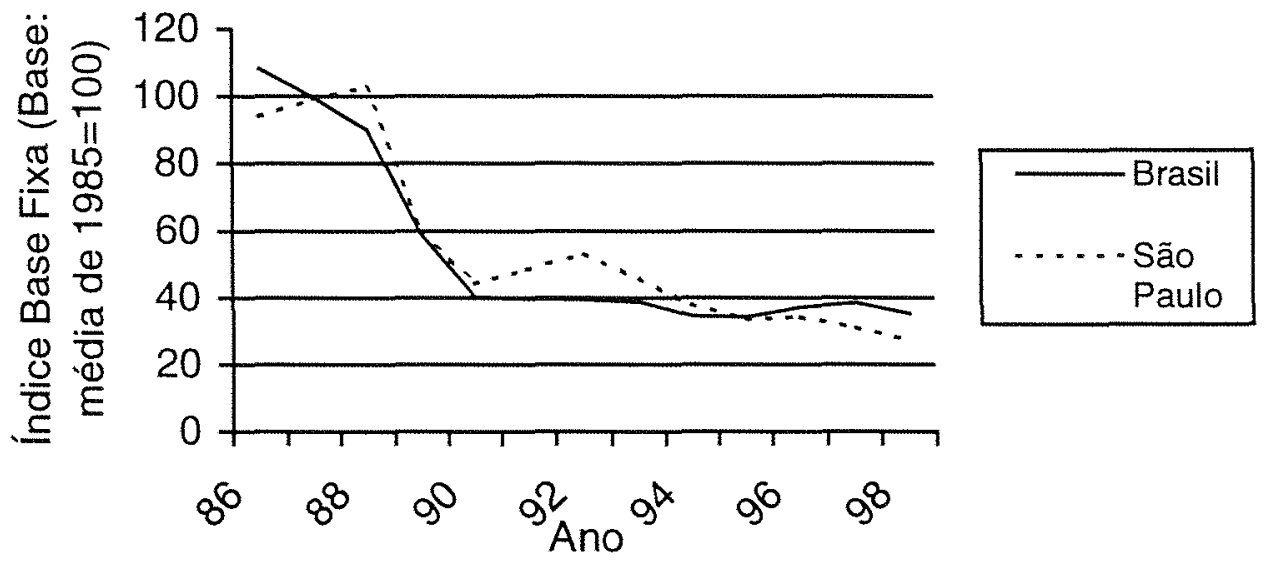

Figura 2 - Evolução do Índice de Produção Real de Toras de Nativas, Brasil e São Paulo, 1986 a 1998 (base 1985=100)

Fonte:www.ibge.gov.br

\subsection{O Processo de Certificação de Produtos oriundos de Madeiras Nativas no Brasil}

O processo de certificação de produtos oriundos de madeira nativa no Brasil tem se desenvolvido, em princípio, em resposta às pressões de grupos de consumidores externos. Segundo Tomaselli (1989), em 1989, o Conselho Internacional da Madeira Tropical estabeleceu que, a partir do final deste século, toda madeira tropical comercializada no mercado internacional será oriunda de florestas manejadas de forma sustentada. Conforme Moncada (1995), uma das formas de pressão adotadas pelos países desenvolvidos é a conscientização da sociedade através de campanhas para a adoção de produtos ambientalmente corretos, como os que possuem "selo verde" ou "certificado de origem".

De acordo com Tomaselli (1994), os "selos verdes" são a denominação genérica para sistemas de verificação da qualidade ambiental dos produtos colocados no mercado. Para que um produto receba o selo verde é feito um levantamento global do impacto do 
em todo seu ciclo de vida, incluida a sua produção, distribuição, uso e descarte. Não obstante, o processo de extração da matéria-prima não é considerado para a grande maioria dos selos verdes, o que difere estes dos sistemas de certificação de origem que vêm sendo discutidos para o caso de madeiras.

Para Tomaselli (1994), a conscientização do consumidor brasileiro poderá ser mais longa. De qualquer maneira, a consolidação do consumo dos produtos de madeira certificada está ligada à credibilidade das empresas certificadoras e dos certificados adotados junto aos consumidores.

Atualmente, existem várias iniciativas - em níveis internacional, regional e nacional - para a certificação da madeira. Segundo Moncada (1995), o Conselho de Manejo Florestal (FSC), fundado em 1993, é o organismo internacional privado mais conhecido, de caráter independente e autônomo, envolvido no processo de certificação de produtos de madeiras tropicais. De acordo com Smeraldi \& Veríssimo (1999), em 1992, a entidade norteamericana Rainforest Alliance (depositária do selo SmartWood, que depois passou a ser credenciado pelo FSC) certificou a primeira empresa brasileira, a Amacol, que em 1996 perdeu a certificação. O Imaflora - Instituto de Manejo e Certificação Florestal e Agricola - criado em 1995, foi a primeira instituição certificadora do hemisfério Sul no setor florestal. Os primeiros padrões de certificação do Imaflora foram estabelecidos para a caixeta, na Mata Atlântica, assim como castanha-do-pará, na Amazônia.

Não obstante, a produção de madeira certificada no Brasil ainda é pequena. Conforme Smeraldi \& Veríssimo (1999), os princípios e critérios internacionais do FSC começaram a ser utilizados no nosso pais somente em 1997. Das 17 empresas certificadas com o selo FSC no Brasil, apenas uma é produtora de madeira da Amazônia.

A certificação tem se desenvolvido principalmente nos estados do Paraná e Santa Catarina, com ênfase em florestas plantadas. Essas podem ser com essências exóticas ou nativas. A implantação de reflorestamentos com essências nativas e seguindo os critérios necessários para obter a certificação permite o atendimento de certos nichos de mercado que estão em expansão. 
Deve-se ressaltar que, seja pela exploração de florestas nativas ou florestas plantadas, a grande maioria dos sistemas de certificação observa se o produtor de madeira respeita a política pública regulamentatória do uso da floresta.

\subsection{A Legislação Florestal Brasileira}

A legislação florestal brasileira pode influenciar a produção de madeiras de espécies nativas estabelecendo e condicionando o grau de exploração de áreas com florestas nativas. Alguns dos instrumentos públicos vistos no capítulo 2 estão definidos e instituídos nas várias leis que tratam do assunto. Assim, as áreas com florestas nativas foram agrupadas em três categorias: áreas com exploração proibida, áreas com exploração limitada e áreas com exploração permitida (vinculadas à reposição florestal obrigatória).

\subsection{1 Áreas com Exploração Proibida}

Estão definidas em atos normativos distintos os seguintes tipos de áreas onde é vedada a exploração econômica de espécies florestais, mesmo que em manejo sustentável: áreas de preservação permanente; parques nacionais, estaduais e municipais; e, as reservas biológicas (ver apêndice 1 para a descrição dessas áreas).

\subsection{2 Áreas com Exploração Limitada}

Comparadas às áreas com exploração proibida, as áreas com exploração limitada, estabelecidas pela legislação, encontram-se em um patamar menos rígido para a ação humana. Isto porque, a extração, seguindo procedimentos recomendáveis, de produtos pode gerar renda e evitar a destruição destas áreas. As áreas com estas características, definidas em atos normativos, são subdivididas na seguinte forma: florestas em áreas ingremes; florestas situadas nas regiões Leste Meridional, Sul e Centro-Oeste, esta na parte sul; reserva legal; Florestas Nacionais; Reservas Extrativistas; remanescentes da Mata Atlântica; e, florestas da bacia amazônica (ver apêndice 2 para a descrição das áreas). 


\subsection{3 Áreas com Exploração Permitida (vinculadas à reposição florestal obrigatória)}

Uma das formas para se tentar reduzir o ritmo da redução da cobertura florestal no Brasil foi a instituição da reposição florestal obrigatória. Este procedimento visa a formação de áreas reflorestadas com recursos vindos dos consumidores de matéria-prima florestal. Dependendo da forma como é feita a reposição, a exploração dos produtos, nestas áreas, pode ter destino certo ou não. O Código Florestal de 1965 trata deste assunto nos artigos 19,20 e 21. Posteriormente, os mesmos foram regulamentados pelo Decreto $n^{\circ} 1.282$, de $19 / 10 / 94$.

No atual Código Florestal alguns pontos merecem ser destacados. Primeiro, para que uma floresta ou formação sucessora seja explorada é necessário não só a aprovação do Instituto Brasileiro do Meio Ambiente e dos Recursos Naturais Renováveis (IBAMA), mas também a adoção de técnicas compativeis com os vários ecossistemas relacionados com a cobertura a ser explorada. A reposição florestal com espécies nativas é uma técnica que deve ser priorizada (artigo 19). Já nos artigos 20 e 21 estabelece-se, para determinadas situações, uma vinculação entre consumo e a obtenção de matéria-prima, de forma racional.

No caso de empresas industriais que são grandes consumidoras de matéria-prima florestal, torna-se obrigatório o plantio de florestas em terras próprias ou de terceiros. A produção, sob exploração racional, deve suprir o consumo próprio (artigo 20 do Código Florestal). No caso de empresas siderúrgicas, de transporte e outras, à base de carvão vegetal, lenha ou outra matéria-prima vegetal, também é obrigatório a manutenção de florestas próprias para a exploração racional ou a formação, direta ou por intermédio de empreendimentos florestais dos quais participem, de florestas destinadas ao seu suprimento (artigo 21 do Código Florestal). Em ambos os casos, a exploração destas áreas, vinculadas à reposição obrigatória, tem destino certo.

A regulamentação feita pelo Decreto $\mathrm{n}^{\circ} 1.282 / 94$ permitiu definir quem era obrigado a fazer a reposição florestal e de que forma. Pelo artigo $9^{\circ}$ desse decreto, tal obrigação cabe a toda pessoa fisica ou jurídica que explore, utilize, transforme ou consuma matéria-prima 
florestal. O plantio deve ser feito no Estado de origem da matéria-prima, de preferência com espécies nativas, de forma que a produção seja ao menos igual ao volume necessário à manutenção da atividade desenvolvida.

Além disso, existem duas categorias de pessoas fisicas ou jurídicas para o propósito de reposição florestal: os grandes consumidores de matéria-prima florestal e os demais consumidores. Para os primeiros é obrigatório manter ou formar, diretamente ou em participação com terceiros, florestas destinadas à sustentação da atividade. Também devem apresentar ao IBAMA o Plano Integrado Florestal (PIF) que inclui uma programação anual de suprimento de matéria-prima florestal (artigos 11 e 12 do Decreto 1.282/94). Assim, a produção oriunda destas áreas tem destino certo.

Já os demais consumidores têm duas opções para cumprir a reposição florestal. Uma é apresentando os levantamentos circunstanciados de florestas próprias ou de terceiros, para fins de vinculação (produção com destino certo). Outra é executando ou participando de programas de fomento florestal, de acordo com a legislação e os regulamentos específicos. Novamente, enfatiza-se que os projetos públicos de manejo florestal, florestamento e reflorestamento devem dar preferência às espécies nativas (artigo 14 do Decreto 1.282/94).

Do exposto acima, constata-se que há uma demanda institucional pelo estabelecimento de reflorestamentos homogêneos ou heterogêneos com espécies nativas para fins de produção de madeira. Soma-se a isto a demanda estratégica de empresas que poderão, no futuro, ficar sem a oferta oriunda do extrativismo (como visto no item 3.1) ou que desejam atender mercados diferenciados (como visto no item 3.2). Mas será que existem pesquisas suficientes e procedimentos técnicos adequados para estabelecer esses reflorestamentos? 


\section{PESQUISAS E RESULTADOS COM REFLORESTAMENTOS DE ESSÊNCIAS NATIVAS}

O propósito deste capítulo é, primeiro, fornecer uma visão global da pesquisa com essências nativas no Brasil. Baseado neste contexto, são analisados os resultados obtidos com os reflorestamentos experimentais realizados pelo Instituto Florestal (IF), da Secretaria do Meio Ambiente do Estado de São Paulo. A partir dos resultados apresentados nos trabalhos científicos, são selecionados os possiveis projetos de reflorestamento com espécies florestais nativas para o caso do Estado de São Paulo.

A visão global é alcançada pela análise das principais tendências das pesquisas sobre essências nativas e os gargalos existentes (item 4.1). Para isso, são selecionados os principais veículos de divulgação científica no Brasil. As pesquisas estão agrupadas em várias áreas do conhecimento, o que permite uma análise mais profunda. Dessa forma, são identificadas as limitações e as reais perspectivas do reflorestamento com essências nativas.

Paralelamente à evolução das várias áreas de pesquisa, procura-se analisar o caso do reflorestamento no Estado de São Paulo (item 4.2). Esta limitação foi estabelecida em função das diferentes condições regionais e da grande quantidade de espécies existentes. Dessa forma, em função da quantidade e idade dos experimentos já desenvolvidos, o Instituto Florestal foi considerado a fonte mais segura para obtenção destes resultados.

Finalmente, baseado no quadro geral e nos resultados do Instituto Florestal, são selecionados os possiveis projetos técnicos de reflorestamento com essências nativas, para fins de produção de toras para o processamento mecânico. 


\subsection{As Pesquisas com Essências Nativas}

Como já comentado parcialmente na introdução deste trabalho, no começo deste século, a Companhia Paulista de Estradas de Ferro necessitava de matéria-prima florestal para usar como combustivel nas suas locomotivas, e madeira para postes, dormentes e demais aplicações. Então, Edmundo Navarro de Andrade realizou estudos comparativos do desenvolvimento de essências nativas e exóticas de valor econômico. $\mathrm{O}$ melhor desempenho do eucalipto estimulou a intensificação desta cultura muito mais do que as demais espécies florestais nativas (Gurgel Filho, 1962).

Já a cultura do Pinus (pinocultura) teve sua expansão contida pela competição direta das abundantes matas nativas de pinheiro-brasileiro (Araucaria angustifolia). Somente na segunda metade deste século os reflorestamentos com espécies de Pinus começaram a se tornar economicamente atrativos diante da escassez do pinheiro-brasileiro (Prates, 1979). Diante do melhor desempenho das espécies de Pinus e Eucalipto sobre as essências nativas, intensificaram-se as pesquisas daquelas.

Segundo Antonangelo (1996), os trabalhos científicos publicados sobre as espécies exóticas (Pinus e Eucalipto) prevaleceram sobre os referentes às essências nativas e sobre as espécies de araucária. Foi durante o periodo de incentivos fiscais oferecidos pelo governo federal, em especial na década de setenta, que esta supremacia se tornou mais evidente. Para Reis (1982), neste período a pesquisa florestal teve um avanço razoável, acompanhada pelo desenvolvimento do ensino florestal. Em 1971 foi implantado o Projeto de Desenvolvimento e Pesquisa Florestal (PRODEF), com o apoio do Programa das Nações Unidas para o Desenvolvimento (PNUD). Assim, foi se formando um seleto grupo de pesquisadores florestais distribuídos em uma extensa rede de experimentação no Brasil.

De acordo com Antonangelo (1996), a partir da década de oitenta, uma conjunção de fatores (pressões internas e externas contra o desmatamento, legislação mais rigorosa, etc.) levaram a intensificação das pesquisas sobre reflorestamento com espécies florestais nativas. A realização do Congresso Nacional sobre Essências Nativas, em 1982, foi um marco para a pesquisa com essas essências. 
A tabela 1 apresenta a evolução da quantidade de trabalhos científicos publicados no Brasil sobre essências nativas. Esta tabela e diversas outras deste capitulo foram elaboradas com base nas revistas FLORESTA (no período de 1969 a 1996), Revista do IPEF (no período de 1970 a 1995), ÁRVORE (no período de 1977 a 1997) e SCIENTIA FORESTALIS (1996 e 1997); nos Anais do I, II, III, IV, V, VI e VII CONGRESSOS FLORESTAIS BRASILEIROS, realizados nos anos de 1953, 1973, 1978, 1983, 1986, 1990 e 1993, respectivamente; e, nos Anais dos CONGRESSOS NACIONAIS SOBRE ESSÊNCIAS NATIVAS (1982 e 1992).

Tabela 1 - Evolução da quantidade de trabalhos cientificos publicados no Brasil sobre essências nativas (1953 - 1997)

\begin{tabular}{c|c|c|c|c|c|c|c}
\hline Ano & Quantidade & Ano & Quantidade & Ano & Quantidade & Ano & Quantidade \\
\hline 1953 & 6 & 1976 & 4 & 1984 & 4 & 1992 & 48 \\
\hline 1969 & 2 & 1977 & 9 & 1985 & 5 & 1993 & 58 \\
\hline 1970 & 4 & 1978 & 14 & 1986 & 31 & 1994 & 7 \\
\hline 1971 & 3 & 1979 & 4 & 1987 & 7 & 1995 & 13 \\
\hline 1972 & 5 & 1980 & 7 & 1988 & 3 & 1996 & 6 \\
\hline 1973 & 16 & 1981 & 5 & 1989 & 3 & 1997 & 10 \\
\hline 1974 & 2 & 1982 & 60 & 1990 & 26 & & \\
\hline 1975 & 5 & 1983 & 42 & 1991 & 7 & & \\
\hline
\end{tabular}

FONTES: REVISTA FLORESTA (1969 - 1996); REVISTA IPEF (1970 -1995); REVISTA SCIENTIA FORESTALIS (1996 - 1997); REVISTA ÁRVORE (1977 - 1997); CONGRESSOS FLORESTAIS BRASILEIROS (1953, 1973, 1978, 1983, 1986, 1990, 1993); CONGRESSOS NACIONAIS SOBRE ESSENCIAS NATIVAS (1982 e 1992)

A escolha destes veículos de divulgação da produção científica foi baseada na importância dos mesmos para a divulgação da pesquisa silvicultural no Brasil. Até o ano anterior à realização do primeiro Congresso Nacional sobre Essências Nativas foram publicados 86 trabalhos. A partir de 1982 a quantidade de trabalhos cientificos sobre essas essências ganhou grande impulso, não só com os eventos mais específicos sobre elas, mas também com a maior participação desses trabalhos nos Congressos Florestais Brasileiros. 
De 1982 a 1997 foram publicados 330 trabalhos sobre essas espécies, ou seja, quase quatro vezes o que foi publicado no período de 1953 a 1981.

\subsubsection{As Espécies Pesquisadas}

A tabela 2 apresenta $^{2}$ as essências nativas mais pesquisadas no período de 1953 a 1981. Como se pode constatar, a quantidade de espécies pesquisadas ainda era muito pequena, concentrando-se basicamente no pinheiro-brasileiro (Araucaria angustifolia). Esta espécie foi a mais pesquisada devido a intensa devastação dos pinheirais nativos e a sua relevante importância econômica para o Estado do Paraná.

Tabela 2 - Evolução da quantidade de trabalhos científicos publicados no Brasil sobre as essências nativas mais pesquisadas (1953 - 1981)

\begin{tabular}{l|l|l|l|l|l|l|l|l|l|l|l|l|l|l|l}
\hline Nome vulgar (nome científico) & 53 & 69 & 70 & 71 & 72 & 73 & 74 & 75 & 76 & 77 & 78 & 79 & 80 & 81 \\
\hline $\begin{array}{l}\text { Pinheiro-brasileiro } \\
\text { (Araucaria angustifolia) }\end{array}$ & 2 & 1 & 3 & 3 & 4 & 6 & 1 & 1 & 3 & 3 & 5 & 3 & 3 & 2 \\
\hline $\begin{array}{l}\text { Palmiteiro } \\
\text { (Euterpe edulis) }\end{array}$ & & & 1 & 1 & 1 & 1 & & & & 1 & & & & \\
\hline $\begin{array}{l}\text { Pau-marfim } \\
\text { (Balfourodendron riedelianum) }\end{array}$ & & & & & & & & 1 & & & 2 & & & \\
\hline $\begin{array}{l}\text { Timbaúva } \\
\text { Enterolobium contortisiliquum) }\end{array}$ & & & & & & & & 1 & & 1 & & & 1 & \\
\hline $\begin{array}{l}\text { Jatobá } \\
\text { (Hymenaea courbaril) }\end{array}$ & & & & & & & & 1 & & 1 & 1 & & & \\
\hline $\begin{array}{l}\text { Guapuruvu } \\
\text { (Schizolobium parahybum) }\end{array}$ & & & & & & & 1 & & & 1 & & & & 1 \\
\hline $\begin{array}{l}\text { Ipês } \\
\text { (Tabebuia sp.) }\end{array}$ & & & & & & & & 1 & & & & 1 & 1 & \\
\hline
\end{tabular}

FONTES: REVISTA FLORESTA (1969 - 1981); REVISTA IPEF (1970 -1981); REVISTA ÁRVORE (1977 - 1981); CONGRESSOS FLORESTAIS BRASILEIROS $(1953,1973,1978)$

Segundo Carvalho (1982), dos plantios realizados no Paraná através de incentivos fiscais no período de 1967 a 1980, 70,76\% são de espécies exóticas e 29,24\% são com

2 A diferença entre a somatória anual de trabalhos científicos contidos na tabela 1 e a somatória anual daqueles contidos na tabela 2 não é, necessariamente, igual a quantidade anual de trabalhos de outras espécies. Isto porque, um mesmo trabalho pode se referir a mais de uma espécie florestal nativa. 
pinheiro-brasileiro, palmito e outras espécies florestais nativas. Os plantios com essências exóticas, porém, não suprem, por exemplo, o mercado para madeira de lei. Infelizmente, as informações sobre a adaptação ecológica e o comportamento silvicultural das espécies em ensaios de comparação eram poucas no início da década de oitenta. Ainda assim, algumas essências nativas eram consideradas aptas para o reflorestamento no Estado do Paraná. Dentre elas: pinheiro-brasileiro (Araucaria angustifolia), bracatinga (Mimosa scabrella), canafístula (Peltoporum dubium), canela-guaicá ( trichotoma), timbaúva (Enterolobium contortisiliquum) e algumas outras.

Para todo o Brasil, o Programa Nacional de Pesquisa Florestal (PNPF) da EMBRAPA/IBDF apresentou algumas indicações de reflorestamento com essências nativas. Em 1981, havia 174 ensaios, conduzidos pelo PNPF, em desenvolvimento na Amazônia e nas regiões Sul, Sudeste e Nordeste. Para a Amazônia foi constatada a potencialidade do jacarandá-da-baía (Dalbergia nigra) para plantios puros. No caso de empreendimentos comerciais foram indicadas duas espécies: a bracatinga ( Mimosa scabrella) para a região Sul e o freijó (Cordia goeldiana) para região Norte (Galvão, 1982).

Já no periodo de 1982 a 1997, houve uma maior diversificação das espécies estudadas (veja a tabela 3). Enquanto no periodo de 1953 a 1981 apenas o pinheirobrasileiro se destacava na quantidade de trabalhos (veja a tabela 2), no período de 1982 a 1997 as pesquisas publicadas sobre outras espécies intensificaram-se (veja a tabela 3). É importante ressaltar que o fato destas espécies serem as mais pesquisadas - conforme a bibliografia consultada - não significa que outras espécies são menos importantes. Além disso, o acúmulo de conhecimento sobre determinada espécie não tem, necessariamente, uma relação direta com a aptidão desta para reflorestamentos.

Baseado na literatura disponível até 1993, Carvalho (1994) reuniu informações de mais de 1.100 trabalhos técnicos-cientificos, além de informações técnicas inéditas sobre cem espécies florestais brasileiras (relacionadas segundo sua participação na rede experimental do autor e segundo sua importância econômica, silvicultural e ecológica). Tais espécies foram agrupadas em: espécies madeireiras promissoras, espécies madeireiras potenciais, 
espécies madeireiras com silvicultura pouco conhecida, espécies madeireiras com regeneração artificial problemática, espécies recomendadas para geração de energia e revegetação e espécies recomendadas principalmente para reflorestamento ambiental.

Tabela 3 - Quantidade de trabalhos científicos publicados no Brasil das essências nativas mais pesquisadas $(1982-1997)^{3}$

\begin{tabular}{l|l|c}
\hline Nome Científico & Nome vulgar & Quantidade de trabalhos \\
\hline Araucaria angustifolia & Pinheiro-brasileiro & 20 \\
\hline Astronium urundeuva & Aroeira & 13 \\
\hline Balfourodendron riedelianum & Pau-marfim & 9 \\
\hline Cariniana legalis & Jequitibá-rosa & 10 \\
\hline Cedrela fissilis & Cedro & 8 \\
\hline Copaífera langsdorffii & Copaiba & 10 \\
\hline Dalbergia nigra & Jacarandá-da-bahia & 9 \\
\hline Esenbeckia leiocarpa & Guarantã & 8 \\
\hline Euterpe edulis & Palmiteiro & 15 \\
\hline Gallesia gorarema & Pau-d'alho & 8 \\
\hline Hymenaea courbaril var. stilbocarpa & Jatobá & 8 \\
\hline Peltophorum dubium & Canafistula & 14 \\
\hline Tabebuia impetiginosa & Ipê-rosa & 9 \\
\hline Zeyhera tuberculosa & Ipê-felpudo & 9 \\
\hline
\end{tabular}

FONTES: REVISTA FLORESTA (1982 - 1996); REVISTA IPEF (1982 -1995); REVISTA SCIENTIA FORESTALIS (1996 - 1997); REVISTA ÁRVORE (1982 - 1997); CONGRESSOS FLORESTAIS BRASILEIROS $(1983,1986,1990,1993)$; CONGRESSOS NACIONAIS SOBRE ESSÊNCIAS NATIVAS (1982 e 1992)

O quadro 1 traz, de forma resumida, estes grupos, suas características e espécies. Dentre as espécies promissoras, somente o pinheiro-brasileiro (Araucaria angustifolia) e o morototó (Didymopanax morototoni) foram considerados aptos para o plantio comercial no sul e no norte do Brasil, respectivamente.

\footnotetext{
${ }^{3}$ Idem da nota de rodapé 2 , mas agora com relação a tabela 3 ao invés da tabela 2 .
} 
Quadro 1 - Agrupamento de espécies nativas segundo o grau de informação disponível, limitações e potencialidades

\begin{tabular}{|c|c|c|}
\hline Categoria & Características & Espécies \\
\hline $\begin{array}{l}\text { Espécies } \\
\text { Madeireiras } \\
\text { Promissoras }\end{array}$ & $\begin{array}{l}\text { Espécies com valor econômico } \\
\text { comprovado, desempenho } \\
\text { silvicultural aceitável, aptidão } \\
\text { para programas de regeneração } \\
\text { artificial e grande número de } \\
\text { ensaios e parcelas de } \\
\text { comprovação }\end{array}$ & $\begin{array}{l}\text { Araucaria angustifolia, Cariniana estrelensis, } \\
\text { Cariniana legalis, Centrolobium robustum, } \\
\text { Centrolobim tomentosum, Cordia trichotoma, } \\
\text { Dalbergia nigra, Didymopanax morotononi, } \\
\text { Johannesia princeps, Peltophorum dubium, } \\
\text { Talauma ovata, Zeyeria tuberculosa }\end{array}$ \\
\hline $\begin{array}{l}\text { Espécies } \\
\text { Madeireiras } \\
\text { Potenciais }\end{array}$ & $\begin{array}{l}\text { Idem das promissoras, mas } \\
\text { com menos informaç̃̃es em } \\
\text { plantios experimentais ou de } \\
\text { comprovação }\end{array}$ & $\begin{array}{l}\text { Balfourodendron riedelianum, Prunus brasiliensis, } \\
\text { Cabralea canjerana subsp. Canjerana, } \\
\text { Caesalpinia leiostachya, Calophyllum brasiliense, } \\
\text { Centrolobium microchaete, Parapiptadenia rigida, } \\
\text { Colubrina glandulosa var. reitzii, Pterogyne nitens, } \\
\text { Myracrodruon urundeuva, Nectandra lanceolata, } \\
\text { Hymenaea courbaril var. stilbocarpa }\end{array}$ \\
\hline $\begin{array}{l}\text { Espécies } \\
\text { Madeireiras } \\
\text { com } \\
\text { silvicultura } \\
\text { pouco } \\
\text { conhecida }\end{array}$ & $\begin{array}{l}\text { As potencialidades } \\
\text { volumétricas ainda não foram } \\
\text { constatadas, pois a } \\
\text { experimentação é jovem }\end{array}$ & $\begin{array}{l}\text { Apuleia leiocarpa, Aspidosperma polyneuron, } \\
\text { Astronium graveolens, Copaifera langsdorffii, } \\
\text { Dalbergia brasiliensis, Machaerium scleroxylum, } \\
\text { Myracrodruon balansae, Ocotea puberula, } \\
\text { Patagonula americana, Poecilanthe parviflora, } \\
\text { Tabebuia heptaphylla, Tabebuia impetiginosa }\end{array}$ \\
\hline $\begin{array}{l}\text { Espécies } \\
\text { MadeireirasR } \\
\text { egeneração } \\
\text { artificial } \\
\text { problemática }\end{array}$ & $\begin{array}{l}\text { Apresentam problemas como: } \\
\text { crescimento lento, } \\
\text { comportamento heterogêneo e } \\
\text { indefinição de sistemas } \\
\text { silviculturais apropriados }\end{array}$ & $\begin{array}{l}\text { Amburana cearensis, Cedrela fissilis, Ocotea porosa, } \\
\text { Copaifera trapezifolia, Diatenopteryx sorbifolia, } \\
\text { Myrocarpus frondosus, Ocotea catharinensis, } \\
\text { Ocotea odorifera, Tabebuia alba, Virola oleifera, } \\
\text { Tabebuia cassionoides, Ruprechtia laxiflora }\end{array}$ \\
\hline $\begin{array}{l}\text { Espécies } \\
\text { para geração } \\
\text { de energia e } \\
\text { revegetação }\end{array}$ & $\begin{array}{l}\text { Na maioria dos casos a } \\
\text { produção de energia é inferior } \\
\text { ao das espécies exóticas. O } \\
\text { rápido crescimento e a } \\
\text { adaptação a solos pouco férteis } \\
\text { tornam-as importantes para } \\
\text { revegetação. }\end{array}$ & $\begin{array}{l}\text { Anadenanthera colubrina, Anadenanthera falcata, } \\
\text { Anadenanthera macrocarpa, Ateleia glazioviana, } \\
\text { Miconia cinnamomifolia, Mimosa bimucronata, } \\
\text { Mimosa scabrella, Piptadenia gonoacantha. } \\
\text { Piptadenia paniculata, Schinus terebinthifolius, } \\
\text { Mimosa scabrella var. Aspericarpa, Sclerolobium } \\
\text { paniculatum }\end{array}$ \\
\hline $\begin{array}{l}\text { Espécies } \\
\text { para } \\
\text { Refloresta- } \\
\text { mento } \\
\text { ambiental }\end{array}$ & $\begin{array}{l}\text { São espécies cuja madeiras são } \\
\text { consideradas de segunda } \\
\text { qualidade para processamento } \\
\text { mecânico. No entanto, são úteis } \\
\text { para vários fins: uso medicinal, } \\
\text { revegetação, etc. Há grande } \\
\text { variação no grau de informação } \\
\text { entre elas. }\end{array}$ & $\begin{array}{l}\text { Alchornea triplinervia, Bastardiopsis densiflora, } \\
\text { Annona cacans, Bauhinia forficata, Cassia grandis, } \\
\text { Caesalpinia echinata, Cecropia hololeuca, Chrolophora } \\
\text { tinctoria, Citharexylum myrianthum, Chorisia } \\
\text { speciosa, Enterolobium contortisiliquum, Croton } \\
\text { floribundus, Dipteryx alata, Euterpe edulis, Erythrina } \\
\text { falcata, Gallesia gorarema, Inga sessilis, Genipa } \\
\text { americana, Gleditsia amorphoides, etc. }\end{array}$ \\
\hline
\end{tabular}

Fonte: Carvalho (1994) 


\subsubsection{A Evolução das Áreas de Pesquisa}

No inicio deste item, procurou-se analisar a evolução geral das pesquisas com essências nativas no Brasil. Em seguida, foram analisadas as espécies mais pesquisadas, bem como as recomendações de uso mais relevantes. Na presente seção, procura-se agrupar os trabalhos publicados em áreas de pesquisa. Este agrupamento foi baseado no trabalho de Antonangelo (1996) para as espécies de Pinus e Eucalipto. No presente caso, as espécies analisadas são as nativas e consideram-se as informações para o período de 1953 a 1997.

A tabela 4 apresenta a evolução da quantidade de trabalhos científicos publicados no Brasil de acordo com as áreas de pesquisa e seus segmentos. As referências bibliográficas dos trabalhos classificados na tabela 4 estão contidas no Apêndice 3. Duas observações merecem destaque: a revista SCIENTIA FORESTALIS substituiu a revista do IPEF e a soma dos trabalhos por área não é necessariamente igual ao total de trabalhos divulgados (tabela 1), pois um trabalho pode abranger várias áreas de pesquisa. Ao contrário de Antonangelo (1996), em cuja metodologia foi baseada este sub-item, considerou-se de importância fundamental a inclusão dos Congressos Nacionais Sobre Essências Nativas. Portanto, nos anos de ocorrência destes e dos Congressos Florestais Brasileiros, a quantidade total de trabalhos científicos publicados no Brasil foi ampliada. 


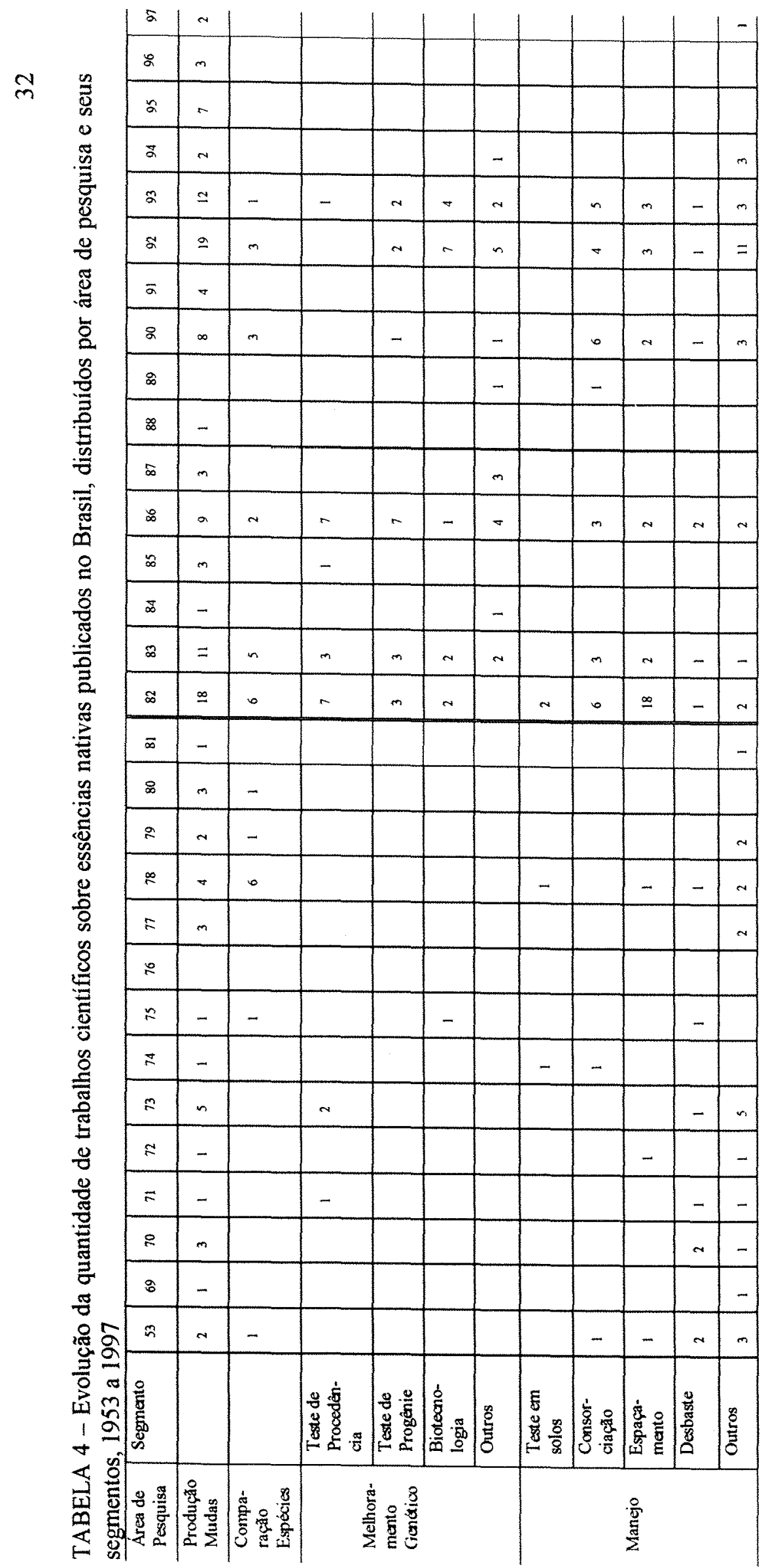




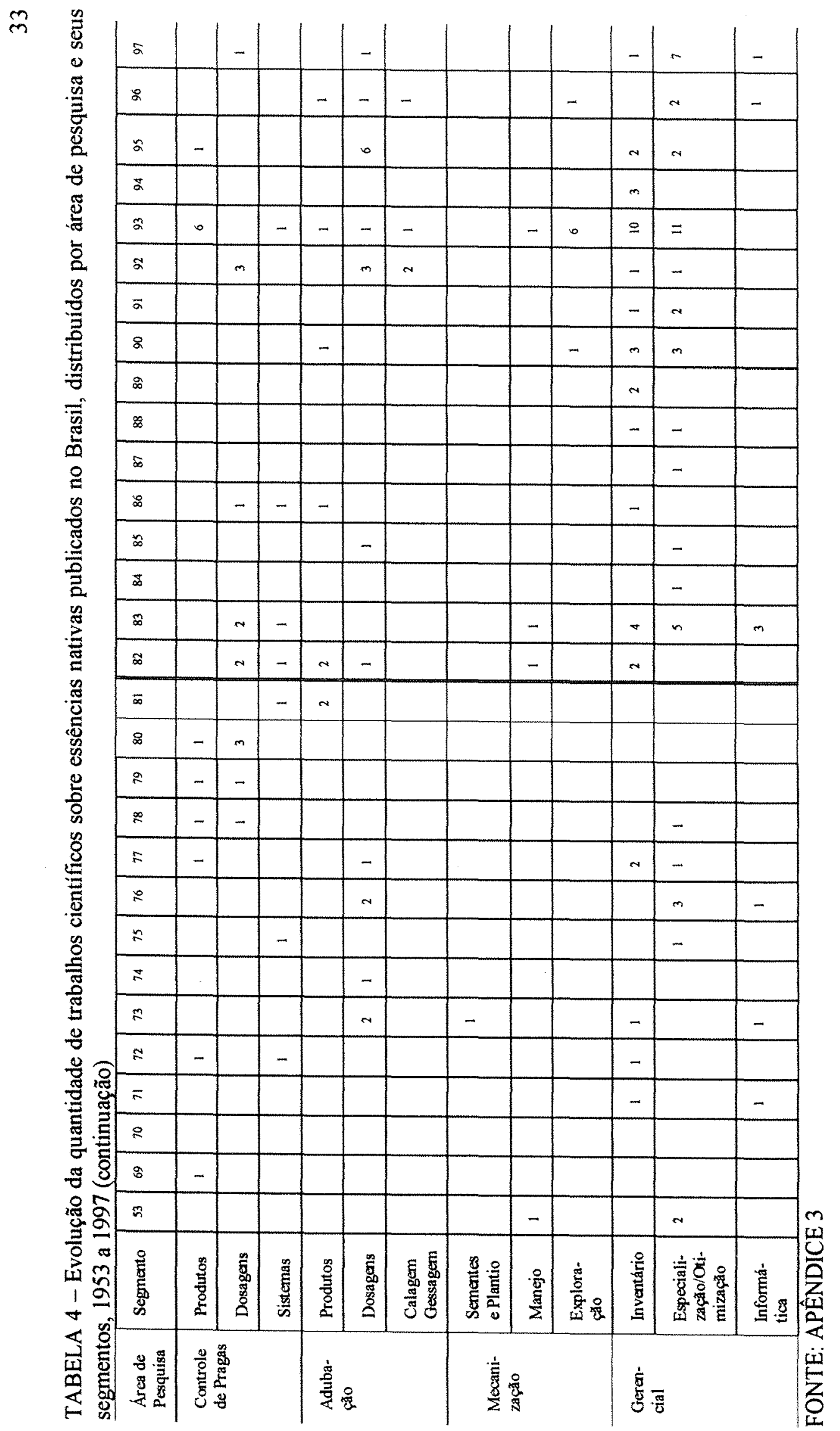


O primeiro grande evento de divulgação técnico-científica na área florestal ocorreu em 1953 com a realização do $1^{\circ}$ Congresso Florestal Brasileiro. Examinando os trabalhos apresentados neste evento, constata-se que as preocupações com as espécies florestais nativas centralizaram-se nas populações de pinheiro-brasileiro que estavam cada vez mais raras. Para isso, achava-se que era necessário uma política florestal voltada ao estabelecimento de modalidades técnicas de preservação e, sobretudo, de recuperação e reflorestamento das áreas já devastadas, concomitantemente com a exploração racional das florestas nativas. No entanto, essas medidas deveriam ser encorajadas através de financiamento e pesquisa governamentais. Isto só veio a ocorrer com o surgimento da lei de incentivos fiscais ao florestamento/reflorestamento - Lei $n^{\circ} 5.106$, de 02/09/66.

No período entre a realização do $1^{\circ}$ Congresso Florestal Brasileiro (1953) e o surgimento de publicações científicas regulares (1969) e a realização do $2^{\circ}$ Congresso Florestal Brasileiro (1973), as pesquisas realizadas com espécies florestais nativas concentraram-se principalmente no pinheiro-brasileiro. Desde 1953, não havia uma definição clara das principais áreas de pesquisa sobre o reflorestamento com outras essências nativas. Na verdade, com o surgimento da lei dos incentivos fiscais concedidos a empreendimentos florestais, a atenção do setor florestal se voltou para as espécies exóticas dos gêneros Pinus e Eucalyptus. Isto porque, o desconhecimento sobre a silvicultura das essências nativas desestimulava a adoção delas como opção de reflorestamento.

Para Simões (1982), a pesquisa com essências nativas tinha sido direcionada para os aspectos básicos da dendrologia ${ }^{4}$ das espécies. Para o autor, além de existirem poucos trabalhos sobre a silvicultura das essências nativas, o sucesso da propagação das espécies e produção de madeira não apresentavam boas perspectivas. Com isso, as tentativas de reflorestamentos comerciais concentraram-se na região Sul, com destaque para o pinheirobrasileiro (Araucaria angustifolia).

\footnotetext{
${ }^{4}$ Conforme Mello (1973), a dendrologia é o estudo da árvore, no senso estrito. O termo é comumente usado no sentido de identificação e classificação sistemática das árvores. Ao lado da taxonomia, ela se ocupa do estudo morfológico e fisiológico das árvores.
} 
Outro ponto destacado foi a influência exercida pelas empresas privadas no tipo de pesquisa desenvolvida pelas instituições apoiadas financeiramente por elas. $O$ interesse destas empresas por pesquisas sobre culturas comprovadamente rentáveis acabou influenciando negativamente a quantidade de trabalhos sobre essências nativas.

Para realizar algumas considerações sobre o comportamento das várias áreas de pesquisa, de 1953 a 1997, o período é dividido em duas fases: a primeira fase vai de 1953 a 1981 e a segunda fase compreende os anos de 1982 a 1997. A primeira fase é caracterizada pelo pequeno número de trabalhos e espécies pesquisadas. $\mathrm{Na}$ segunda fase ocorre a expansão do número de trabalhos e espécies pesquisadas.

$\mathrm{Na}$ primeira fase do periodo em análise (1953 a 1981), a pesquisa na área de produção de mudas foi a que teve o maior número de trabalhos e a distribuição mais uniforme entre os anos. Os primeiros trabalhos podem ser considerados mais informes técnicos, em que eram reunidas informações empíricas sobre como produzir as mudas. A germinação foi um tema bastante estudado, tanto na questão da influência das condições de armazenamento e conservação das sementes, quanto nas técnicas de quebra de dormência. $\mathrm{Na}$ semeadura, as questões mais discutidas foram a profundidade ideal e a temperatura. $\mathrm{E}$, vários trabalhos estudaram o efeito do sombreamento nas mudas.

A área de competição entre as espécies pode ser considerada como uma predecessora do melhoramento genético. Por muitos anos acumulou-se conhecimento sobre as utilidades das madeiras encontradas na mata nativa, mas a reprodução destas carecia de maiores informações. As primeiras iniciativas foram orientadas para a observação do desempenho relativo entre espécies em condições edafo-climáticas especificas. Já o melhoramento genético de essências nativas pode ser obtido pela seleção de populações e, em seguida, pela seleção dentro de populações. 
Segundo Kageyama \& Dias (1982), o ensaio de procedências é a primeira etapa no melhoramento. As espécies Araucaria angustifolia (pinheiro-brasileiro), Mimosa scabrella (bracatinga) e Cordia goeldiana (freijó) - que vinham sendo utilizadas em reflorestamentos - encontravam-se nesta etapa. O passo seguinte é a seleção dentro de populações (teste de progênie) já em talhões implantados. As pesquisas nesses anos (1953 a 1981), concentraramse na primeira etapa.

A área de manejo é a que possuiu a maior quantidade ${ }^{5}$ de trabalhos (32). As diferentes condições ecológicas das várias regiões brasileiras exigem formas diferentes de instalação de uma cultura. São vários os segmentos a serem pesquisados diante das necessidades e número de espécies. Dentre os segmentos de pesquisa, os trabalhos relacionados ao desbaste mereceram atenção especial. Trabalhos sobre teste em solos, consorciação e espaçamento foram mínimos. Outros temas surgiram como: plantio direto, importância da poda na qualidade da madeira, regeneração natural, a introdução de espécies em áreas abandonadas e o efeito do sombreamento para algumas espécies.

Diante da pouca quantidade de reflorestamentos com essências nativas, as pesquisas com adubação, mecanização e controle de pragas e doenças foram mínimas. Pode-se destacar alguns trabalhos sobre os efeitos da ausência de nutrientes ou o teor de alumínio sobre plantas de pinheiro-brasileiro. No controle de pragas e doenças, desenvolveram-se, concomitantemente, pesquisas sobre o controle biológico e químico. $\mathrm{Na}$ área gerencial, apesar de vários trabalhos terem sido desenvolvidos em função dos reflorestamentos com Pinus e Eucalipto, muitos deles poderiam ser adaptados para as espécies florestais nativas.

A segunda fase do período em análise (1982-1997) apresentou um comportamento distinto do primeiro, a começar pela quantidade de trabalhos ser muito superior. A realização de eventos específicos sobre essências nativas (Congressos Nacionais) foi um sinalizador do crescimento da importância destas espécies para a silvicultura brasileira. Além disso, os

\footnotetext{
${ }^{5}$ Um mesmo trabalho dentro de uma área de pesquisa pode abordar mais de um segmento. Por exemplo, na área de manejo foram encontrados 32 trabalhos. mas dois deles abordam dois segmentos, o que totaliza 34 trabalhos se somarmos estes na tabela 4 .
} 
trabalhos com essências nativas passaram a ter maior participação nos Congressos Florestais Brasileiros.

As pesquisas na área de produção de mudas intensificaram-se ainda mais, tornandose a mais pesquisada. Além dos temas já mencionados no primeiro periodo, surgiram outras questões como a composição ideal do substrato e os tipos de cobertura das embalagens. Outro assunto de grande impacto foi o tipo de recipiente usado na produção de mudas. De acordo com Campinhos Júnior \& Ikemori (1983), a introdução do sistema "dibble-tube" para produção de mudas de essências florestais apresentou vantagens sobre o sistema que até então era utilizado. A utilização dos tubos de polipropileno em bandejas proporcionou, dentre outras coisas, a mecanização de várias fases da operação de produção de mudas. Apesar de ser implantado para a produção de mudas de Eucalipto, a sua utilização para a produção de mudas de essências nativas não apresenta restrições intransponíveis até o momento.

A área de melhoramento genético florestal foi uma das que mais se desenvolveu intensificaram-se os testes de procedência e progênies. Para Kageyama \& Dias (1982), um programa de sementes melhoradas para uma determinada espécie só faz sentido se tanto a silvicultura quanto o fim a que se destina a produção já estiverem devidamente definidos. Como muitas das espécies não se enquadram nesta situação e o desmatamento tem causado grande perda de material genético, vários testes têm sido utilizados para a conservação genética das espécies.

No segmento "outros", da área de melhoramento genético, o número de trabalhos sobre conservação ex situ e in situ é expressivo. Isto porque a ameaça de perda do material genético de várias espécies incentivou ações como o "Programa de Conservação Genética do Instituto Florestal de São Paulo" (Nogueira et al., 1982 a; Siqueira \& Nogueira, 1992). A conservação de espécies também tem motivado trabalhos sobre propagação vegetativa. A biotecnologia é um segmento da pesquisa com tendência a expansão, pois a sua utilização facilita a obtenção de plantas que, por muitas vezes, é inviável de serem obtidas através da via sexuada. 
$\mathrm{Na}$ área de manejo, três segmentos se destacaram: consorciação, espaçamento e as pesquisas agrupadas em "outros". No segmento da consorciação pode-se observar uma tendência crescente a realização de trabalhos testando combinações de espécies representantes dos grupos sucessionais. Um exemplo disto é o empenho da Companhia Energética de São Paulo (CESP) na recomposição de matas nativas através de plantios mistos. Apesar de muitos destes plantios terem sido feitos empiricamente, a tendência atual é realizá-los com o devido embasamento científico. Assim, conceitos básicos de fitossociologia e sucessão secundária não têm mais sido ignorados (Silva, 1992).

Os reflorestamentos mistos com espécies nativas têm desempenhado importante papel na recuperaração de áreas degradadas. Dependendo do caso, é a melhor alternativa técnica para a recuperação das funções ambientais. Além disso, estas áreas podem exercer uma função produtiva, a despeito de serem consideradas viáveis ou não economicamente quando se considera apenas os beneficios diretos (como madeira, sementes, frutos etc.).

Enquanto os trabalhos sobre consorciação tiveram uma distribuição mais uniforme neste período, o espaçamento foi mais pesquisado no começo da década de oitenta. No segmento "outros" da área de manejo, pode-se destacar os seguintes temas: manejos específicos para áreas de mata ciliar, introdução de espécies em área degradadas, regeneração natural em áreas recompostas, etc.

Nas áreas gerencial e controle de pragas, muitos dos trabalhos considerados foram desenvolvidos para reflorestamentos com essências exóticas. No entanto, da leitura destes subentendeu-se que poderiam ser, em parte, adaptados e aplicados as essências nativas. Já a área de pesquisa sobre adubação vem sinalizando um crescimento a partir da década de noventa, com trabalhos sobre exigências nutricionais e o crescimento de nativas em resposta a fósforo, nitrogênio, rizóbio e fungo micorrízico.

Fruto dos trabalhos de pesquisa relatados acima, alguns projetos de reflorestamento com essências nativas têm se tornado viáveis. No próximo item são discutidos os resultados obtidos pelo Instituto Florestal em São Paulo e os possiveis projetos técnicos de reflorestamento comercial com as espécies florestais nativas. 


\subsection{A Experiência do Instituto Florestal em São Paulo}

A história da pesquisa com essências nativas no Brasil está muito relacionada com a do Instituto Florestal (IF) de São Paulo. As tendências e enfoques observados na pesquisa foram fortemente influenciados pelos trabalhos publicados pelos pesquisadores do IF. Já na década de quarenta, do presente século, foram realizados os primeiros estudos. No entanto, as conclusões mais consistentes, quanto às perspectivas de reflorestamento, começaram a surgir no final da década de setenta.

De acordo com Garrido et al. (1978), muitos desses experimentos mostravam evidências da viabilidade silvícola para várias espécies. Por outro lado, os resultados parciais de estudos mais recentes (sobre crescimento e aspectos silvicuturais) tiveram grande divulgação no Congresso Nacional sobre Essências Nativas realizado em 1982. Após este evento a divulgação de novos resultados de plantios experimentais foi mínima.

\subsubsection{Os resultados obtidos pelo Instituto Florestal}

No item 4.1 pôde-se observar que, até 1981, a quantidade de pesquisas sobre essências nativas ainda era pequena frente às muitas questões a serem tratadas. Mesmo assim, o IF, através do trabalho apresentado por Gurgel Filho et al. (1978), contribuiu em muito para a silvicultura de espécies nativas. Até então, existia uma grande carência de informações a respeito de experimentos com periodos mais longos.

No trabalho acima citado, foram feitas observações e análises de experimentos com cerca de 20 anos. Os experimentos foram instalados a partir de 1952 sob a forma de povoamentos puros situados na Estação Experimental de Santa Rita do Passa Quatro, na região nordeste do Estado de São Paulo. As espécies estudadas foram: pinheiro-brasileiro (Araucaria angustifolia), araruva (Centrolobium tomentosum), Ibirá-puitá (Peltophorum vogelianum), jatobá (Hymenaea stilbocarpa), pau-ferro (Caesalpinia leiostachya), pau-pereira (Platycyamus regnellii), pau-marfim (Balfourodendron riedelianum), guarantã (Esenbeckia leiocarpa) e peroba-rosa (Aspidosperma polyneuron). 
Dentre as nove espécies pesquisadas, foram consideradas três com maiores viabilidades econômicas: aranuva, pau-marfim e o pinheiro-brasileiro. Esta escolha foi baseada nas grandes diferenças de crescimento volumétrico entre as espécies (de até seis vezes) e na exigência natural da formação do fuste (isto é, da parte comercial do tronco). Outros fatores técnicos relacionados ao rendimento dendrométrico (por exemplo, a porcentagem de casca e a forma do tronco) corroboraram a escolha dessas espécies.

As demais conclusões do trabalho Gurgel Filho et al. (1978) tiveram repercussões diferentes nas pesquisas realizadas nos anos subseqüentes. A influência da fertilidade do solo no crescimento das espécies ficou evidente. No entanto, o crescimento do número de trabalhos sobre adubação (veja tabela 4, no subitem 4.1.2) foi pequeno, sendo vários deles relacionados à produção de mudas. Por outro lado, também se concluiu que as demais espécies, cuja formação do fuste não era natural, exigiam uma composição sob povoamentos mistos. A evolução dos trabalhos de pesquisa, analisados no item 4.1, sinalizam o expressivo crescimento do número de trabalhos de pesquisa sobre a consorciação de espécies.

Posteriormente, em 1982, esse trabalho foi reavaliado por Gurgel Filho et al.(1982 a, b, c, d, e, f, g, h, i). As principais conclusões destes trabalhos não contrariam aquelas do trabalho Gurgel Filho et al. (1978), apesar da idade mais avançada dos experimentos. Adicionaram-se à primeira avaliação, a necessidade de um programa de melhoramento genético diante da grande heterogeneidade do material básico. Esta medida poderia proporcionar ganhos de incremento volumétrico significativos. Esta conclusão contribuiu para o crescimento das pesquisas desenvolvidas pelo IF, na área de melhoramento genético, refletindo no crescimento dos trabalhos publicados nesta área. Este foi o tema de alguns dos trabalhos apresentados pelos pesquisadores do IF, no Congresso Nacional sobre Essências Nativas, em 1982. No mesmo evento foram apresentados trabalhos sobre o reflorestamento com essências nativas que poderiam ser divididos em três grupos: maduros (mais de 20 anos), adultos (14 anos) e jovens (inferiores a 10 anos).

Sobre o grupo dos experimentos maduros, além dos trabalhos de Gurgel Filho et al. (1982 a, b, c, d, e, f, g, h, i), já comentados, inclui-se o de Gurgel Filho et al. (1982j). Neste, 
foram apresentados os resultados do crescimento em altura e DAP (diâmetro a altura do peito), por mais de 20 anos, de outras sete espécies nativas. Os ensaios também foram estabelecidos em Santa Rita do Passa Quatro - SP, e dentre as espécies analisadas, três se destacaram: anda-açú (Joannesia princeps), angico (Piptadenia macrocarpa) e cedro (Cedrella fissilis).

No grupo de experimentos adultos dois trabalhos foram apresentados. O mais importante foi o estudo dos caracteres silviculturais e competição entre dez espécies folhosas nativas, na Estação Experimental de São Simão (Gurgel Filho et al., 1982k). Dentre as espécies estudadas concluiu-se que o jequitibá vermelho (Cariniana legalis) e o pau-marfim (Balfourodendron riedelianum) apresentaram-se aptos, do ponto de vista biológico e econômico, para o reflorestamento a céu aberto.

Os experimentos jovens (com menos de 10 anos) foram estabelecidos em outras regiões do Estado de São Paulo. Apesar dos resultados apresentados para esses experimentos serem muito preliminares, é possivel avaliá-los, desde que guardadas as devidas proporções para comparações. Um aspecto relevante observado é a influência das condições dos experimentos no resultado encontrado. Um bom exemplo destas distorções foi a pesquisa conduzida por Nogueira et al. (1982c). Em 1975, foi montado um ensaio para se observar a competição entre algumas espécies nativas, em diferentes regiões do Estado de São Paulo. As espécies: araruva, ibirá-puitá, ipê-amarelo, jequitibá-vermelho e pau-marfim foram plantadas na mesma época, nas seguintes regiões: Assis, Bebedouro, Luiz Antônio e Pederneiras.

Apesar da padronização das operações, os resultados foram afetados por algumas condições estruturais e outras ocasionais. As condições de fertilidade do solo foram as seguintes: fraca (em Assis e Bebedouro), média (em Pederneiras) e ótima (em Luiz Antônio). A ocorrência natural das espécies na região, como foi o caso de Luiz Antônio, também teve grande influência. O jequitibá-vermelho foi a espécie com maiores dificuldades de adaptação. Com a geada ocorrida em 1981, esta espécie foi a mais atingida. Ainda assim, concluiu-se que o ibirá-puitá e o pau-marfim foram as espécies com melhor desempenho. 
Já sob as condições de Mogi Guaçu, o ibirá-puitá não apresentou bom desenvolvimento (Coelho et al., 1982). Aos 8 anos, o crescimento era inferior ao observado em Pederneiras, aos 6 anos (Nogueira et al., 1982c). Apesar de não ter sido dado maiores detalhes do experimento em Mogi Guaçu, as diferenças podem estar associadas à fertilidade do solo ou adaptação da espécie. Além destes, foram divulgados três trabalhos cujos experimentos tinham 6 anos: pau-marfim, em Assis (Garrido et al.,1982), araruva, em Pederneiras (Nogueira et al., 1982b) e ipê-amarelo, em Bebedouro (Rosa et al., 1982). Com 7 anos, sobre o jequitibá-vermelho em Luiz Antônio tem-se a avaliação de Zanatto et al. (1982); e sobre a canela-imbuia em Angatuba, o trabalho de Souza et al. (1982).

Após a realização do Congresso Nacional sobre Essências Nativas, a divulgação dos resultados de pesquisas, por parte do IF, sobre o crescimento e aspectos silviculturais de espécies nativas, se rarearam. Dentre os trabalhos divulgados, contidos no Apêndice 1 e apresentados na Tabela 4 (do item 4.1), nota-se a ausência de trabalhos que poderiam divulgar resultados mais conclusivos sobre os grupos de experimentos adultos e jovens, comentados anteriormente.

A única pesquisa divulgada, baseada em um longo periodo de experimentação, foi a realizada na Estação Experimental de Assis. Em 1970, foram estabelecidos cinco povoamentos puros e um misto, com as seguintes espécies: saguaragi (Colubrina rufa), ipê roxo (Tabebuia impetiginosa), angico (Piptadenia macrocarpa), cambará (Moquinia polymorpha) e aroeira (Astronium urundeuva). Alguns resultados preliminares foram apresentados aos 4,5 anos (Garrido, 1975) e aos 10 anos (Garrido, 1981).

As conclusões mais significativas dos experimentos acima mencionados começaram a ser apresentadas em 1983. Garrido \& Souza (1983) apresentaram os resultados da produção de madeira de dois desbastes efetuados nesses experimentos. $O$ material retirado serviu para dois fins: moirões e lenha ou material para a produção de carvão. Dentre as espécies estudadas, o angico foi a espécie com melhor performance. No $1^{0}$ e $2^{0}$ desbastes ocorridos em 1978 e 1981 - foram produzidos por hectare, respectivamente: 456 moirões e 29 esteres de madeira empilhada e 469 moirões e $81 \mathrm{~m}^{3}$ de madeira empilhada. 
Após 20 anos de estudos, Garrido et al. (1990) concluíram que as espécies mais aptas para reflorestamento são: angico, cambará e saguaragi; o cambará foi a que apresentou a maior relação cerne/alburno ${ }^{6}$; o melhoramento genético poderá corrigir a forma tortuosa do cambará; o saguaragi apresentou crescimento rápido (mesmo sendo suscetível à geada), sem a necessidade de derrama artificial para a boa formação do fuste; não houve diferenças significativas de crescimento entre os povoamentos puros e misto, com exceção dos valores em altura do saguaragi e aroeira; e, a consorciação foi benéfica para a aroeira.

\subsubsection{Possíveis Projetos Técnicos de Reflorestamento com Essências Nativas}

No sub-item 4.2.1 foram apresentados os resultados, obtidos pelo IF no Estado de São Paulo, dos reflorestamentos experimentais com essências nativas. No quadro 2 são apresentados os experimentos com maior periodo de observação, cujas espécies foram consideradas aptas, pelos autores, para o reflorestamento comercial.

Dentre os experimentos considerados aptos pelos autores, somente aqueles citados por Gurgel Filho et al.(1978) estão sendo selecionados como possíveis projetos técnicos. Isto porque os experimentos com as espécies selecionadas por Gurgel Filho et al.(1982j) carecem de maiores informações, necessárias para a análise econômica. Por outro lado, o trabalho de Garrido et al. (1990) está sendo descartado por utilizar espécies aptas a produção de moirões e postes, quando o objeto principal deste trabalho é analisar a viabilidade econômica de reflorestamentos com essências nativas para a produção de toras a serem utilizadas na indústria de desdobro mecânico das mesmas

\footnotetext{
${ }^{6}$ O cerne é a parte mais resistente e durável da madeira. Portanto, apesar de não ter o crescimento mais rápido, se o uso da madeira for como moirão. o cambará pode ser usado mais cedo do que outras espécies. Os cernes encontrados para o cambará, angico e saguaragi são, respectivamente: $8,5 \mathrm{~cm}, 6,8 \mathrm{~cm}$ e $6,1 \mathrm{~cm}$.
} 
Quadro 2 - Essências nativas consideradas aptas para o reflorestamento comercial

\begin{tabular}{|c|c|c|c|c|}
\hline $\begin{array}{l}\text { Nome científico } \\
\text { (nome vulgar) }\end{array}$ & Local & Finalidade & $\begin{array}{l}\text { Tipo de } \\
\text { Solo }\end{array}$ & Fonte \\
\hline $\begin{array}{l}\text { Anda-açu (Joannesia } \\
\text { princeps) }\end{array}$ & $\begin{array}{l}\text { Santa Rita do } \\
\text { Passa Quatro }\end{array}$ & Serraria & LVA/LVE & $\begin{array}{l}\text { Gurgel Filho et al. } \\
(1982 \mathrm{j})\end{array}$ \\
\hline $\begin{array}{l}\text { Angico (Piptadenia } \\
\text { macrocarpa) }\end{array}$ & $\begin{array}{l}\text { Santa Rita do } \\
\text { Passa Quatro }\end{array}$ & Poste e moirão & LVA/LVE & $\begin{array}{l}\text { Gurgel Filho et al. } \\
(1982 \mathrm{j})\end{array}$ \\
\hline Cedro (Cedrella fissilis) & $\begin{array}{l}\text { Santa Rita do } \\
\text { Passa Quatro }\end{array}$ & Serr & LVA/LVE & $\begin{array}{l}\text { Gurgel Filho et al. } \\
(1982 \mathrm{j})\end{array}$ \\
\hline $\begin{array}{l}\text { Araruva (Centrolobium } \\
\text { tomentosum) }\end{array}$ & $\begin{array}{l}\text { Santa Rita do } \\
\text { Passa Quatro }\end{array}$ & Serraria & LVA/LVE & $\begin{array}{l}\text { Gurgel Filho et al. } \\
\text { (1978) }\end{array}$ \\
\hline $\begin{array}{l}\text { Pau-marfim } \\
\text { (Balfourodendron } \\
\text { riedelianum) }\end{array}$ & $\begin{array}{l}\text { Santa Rita do } \\
\text { Passa Quatro }\end{array}$ & Serraria & LVA/LVE & $\begin{array}{l}\text { Gurgel Filho et al. } \\
(1978)\end{array}$ \\
\hline $\begin{array}{l}\text { Pinheiro-brasileiro } \\
\text { (Araucaria angustifolia) }\end{array}$ & $\begin{array}{l}\text { Santa Rita do } \\
\text { Passa Quatro }\end{array}$ & Serraria & LVA/LVE & $\begin{array}{l}\text { Gurgel Filho et al. } \\
\text { (1978) }\end{array}$ \\
\hline $\begin{array}{l}\text { Angico (Piptadenia } \\
\text { macrocarpa) }\end{array}$ & Assis & Poste e moirão & $\begin{array}{l}\text { LVE } \\
\text { distrófico }\end{array}$ & $\begin{array}{l}\text { Garrido et al. } \\
\text { (1990) }\end{array}$ \\
\hline $\begin{array}{l}\text { Cambará (Moquinia } \\
\text { polymorpha) }\end{array}$ & Assis & Poste e moirão & $\begin{array}{l}\text { LVE } \\
\text { distrófico }\end{array}$ & $\begin{array}{l}\text { Garrido et al. } \\
(1990)\end{array}$ \\
\hline $\begin{array}{l}\text { Saguaragi (Colubrina } \\
\text { rufa) }\end{array}$ & Assis & Poste e moirão & $\begin{array}{l}\mathrm{LVE} \\
\text { distrófico }\end{array}$ & $\begin{array}{l}\text { Garrido et al. } \\
(1990)\end{array}$ \\
\hline
\end{tabular}

Portanto, os experimentos selecionados como possiveis projetos técnicos de reflorestamento se referem ao plantio puro do pinheiro-brasileiro, do pau-marfim e da araruva, na região de Santa Rita do Passa Quatro, SP. Pela classificação de Carvalho (1994), o pinheiro-brasileiro e a araruva são consideradas espécies madeireiras promissoras e o paumarfim é considerado uma espécie madeireira potencial (ver o quadro 1).

$\mathrm{O}$ pinheiro- brasileiro possui uma madeira leve (densidade $0,55 \mathrm{~g} / \mathrm{cm}^{3}$ ), macia e pouco durável quando exposta ao tempo. A madeira é própria para forros, molduras, ripas, para confeç̧ão de cabos de vassoura, caixotaria, brinquedos, estrutura de móveis, palitos de fósforos, pás de sorvete, lápis, carretéis, utensilios domésticos, etc (Lorenzi, 1992). Segundo Carvalho (1994), a madeira é de alta qualidade para construções em geral, 
caixotaria, móveis, laminados e vários outros usos.

A araruva possui uma madeira moderadamente pesada $\left(0,75 \mathrm{~g} / \mathrm{cm}^{3}\right)$, com cerne muito decorativo, fibras revessas, porém dócil ao cepilho e à serra, flexível, um tanto dura, de longa durabilidade natural mesmo em condições adversas. A madeira é própria para a construção naval, obras hidráulicas, internas e externas, dormentes, para confecção de portas, canoas, carroçaria, para marcenaria e carpintaria em geral (Lorenzi, 1992). Segundo Carvalho (1994), a madeira também pode ser usada para se fazer tacos, móveis finos, torneados, lambris, postes, moirões, esteios, vigamentos para pontes, cercas, hélices de pequenos aviões e tanoaria.

O pau-marfim possui uma madeira moderadamente pesada $\left(0,84 \mathrm{~g} / \mathrm{cm}^{3}\right)$, dura, medianamente resistente, grã irregular à revessa, textura fina, de baixa resistência ao apodrecimento e ao ataque de insetos. A madeira é indicada para o fabrico de móveis de luxo, molduras, guarnições internas, portas, artefatos domésticos, peças torneadas, laminados decorativos, para construção civil, forma para calçados, tacos de bilhar, cabos de ferramentas, réguas, carpintaria e marcenaria em geral (Lorenzi, 1992).

No próximo capítulo são apresentados os resultados da avaliação econômica dos projetos selecionados. 


\section{RENTABILIDADE ECONÔMICA DOS REFLORESTAMENTOS COM ESSÊNCIAS NATIVAS}

O propósito deste capítulo é fazer a avaliação econômica de projetos de reflorestamento com essências nativas. No capitulo anterior foram selecionados três reflorestamentos experimentais, considerados viáveis do ponto de vista técnico e com as informações disponiveis. Até agora a avaliação econômica desses projetos se baseou em apenas dois critérios: a existência de valor econômico para a madeira da essência nativa e

o pouco número de operações para a retirada de ramos, a fim de se obter um fuste comercial.

Neste capítulo procura-se ir mais adiante na avaliação econômica destes reflorestamentos. No item 5.1 são discutidas quais as condições preliminares para se ter a avaliação econômica de projetos de reflorestamento com essências nativas. No item 5.2 são discutidos e selecionados os métodos, mais adequados para este trabalho, de avaliação econômica de projetos. No item 5.3 são apresentadas as estimativas deterministas de indicadores, pelos métodos selecionados, para os projetos selecionados. No item 5.4 são apresentadas as análises de sensibilidade de algumas variáveis para estas estimativas. E no item 5.5 é realizada a análise de risco pela simulação de Monte Carlo para os projetos. Com esses resultados, as pessoas interessadas no reflorestamento com espécies florestais nativas, no Estado de São Paulo, terão melhores condições para a tomada de decisão sobre a implantação ou não desse tipo de reflorestamento. 


\subsection{Considerações Preliminares}

A avaliação econômica de um projeto de investimento ${ }^{7}$ pressupõe a determinação do respectivo fluxo de caixa, a classificação dos investimentos segundo certas características do fluxo de caixa e a escolha do custo de oportunidade do capital.

O fluxo de caixa são as estimativas de entradas (receitas) e saidas (despesas) dos recursos monetários ao longo do tempo. Para se fazer as estimativas é necessário agrupar os dados das operações em matrizes de coeficientes técnicos e levantar os preços destas operações nos mercados de insumos e produtos. Como as informações técnicas para os projetos estão sendo obtidas a partir de experimentos e não existem informações disponíveis e suficientes sobre reflorestamentos comerciais com essências nativas, as análises de investimento são feitas, em uma primeira etapa, em condições deterministas, ou seja, pressupondo-se certeza quanto aos valores associados aos fluxos de caixa dos projetos de investimento. A fim de se incorporar o risco na análise, em seguida são construídos cenários para se analisar a sensibilidade dos indicadores, a serem selecionados, às alterações em algumas variáveis. Em uma terceira etapa, é realizada a análise de risco pela simulação de Monte Carlo, apresentando a distribuição de probabilidade para os indicadores de rentabilidade escolhidos.

A elaboração das matrizes de coeficientes técnicos é baseada nos trabalhos publicados e no histórico dos experimentos cadastrados no Instituto Florestal. Como se trata de experimentos antigos, algumas informações encontram-se incompletas, sendo necessário estimá-las. Este procedimento é feito com o bom senso de não se alterar as condições básicas de manejo que conduziram aos resultados alcançados. Quanto aos mercados de insumos e produtos, a maior dificuldade é para se obter o preço da madeira em pé das espécies selecionadas. Uma vez obtidos os preços e quantidades, calcula-se os valores dos beneficios e custos para a composição dos fluxos de caixa (veja apêndices $4,5,6$ e 7). O mês de

\footnotetext{
${ }^{7}$ Entende-se por projeto de investimento a aplicação de capital, tanto para a criação de unidades produtivas quanto no mercado de capitais. com a finalidade de obtenção de receitas.
} 
referência para os indicadores a serem calculados, na análise determinista, é março de 1999.

Há dois grandes grupos de fluxos de recursos: entrada e saida. O fluxo liquido é a resultante desses dois fluxos. Sobre ele são aplicadas as técnicas de desconto para calcular a rentabilidade dos investimentos. Geralmente, os itens de entradas são divididos em valor da produção, valor dos subprodutos, valor residual, subsidios governamentais, receitas adicionais; e, os itens de saída são as despesas de investimento e operacionais.

A elaboração do fluxo de caixa também é importante para classificar os projetos. Conforme Faro (1972), os projetos podem ser classificados de acordo com a mudança de sinal na seqüência do fluxo de caixa. No tipo convencional ocorre apenas uma mudança, enquanto no tipo não-convencional ocorre mais de uma mudança. Já Bussey (1978) classifica os projetos em puros ou mistos se, respectivamente, o saldo não recuperado não apresenta mudança de sinal ou se apresenta.

Para se escolher o custo de oportunidade do capital para a avaliação dos projetos foram considerados alguns pontos. Se o investidor dispusesse de capital próprio, ele poderia realizar uma aplicação conservadora no mercado financeiro, como o depósito em caderneta de poupança, obtendo uma taxa líquida real de $6 \%$ ao ano sobre o valor aplicado. Outra opção seria aplicar seu dinheiro no reflorestamento com uma essência exótica, por exemplo o eucalipto, visando fornecer madeira para as empresas de celulose. Neste caso, são usados os dados de Rodriguez \& Rodrigues (1999) para a composição do fluxo de caixa e cálculo das estimativas para se comparar os dois tipos de reflorestamento.

Por outro lado, o investidor poderia obter um financiamento concedido pelo Banco Nacional de Desenvolvimento Econômico e Social (BNDES) para projetos de longo prazo. Neste caso, estaria utilizando a taxa de juros de longo prazo (TJLP), cujos valores tem oscilado entre $9,40 \%$ e $18,06 \%$ ao ano (fora o spread cobrado pelos bancos) para o período de janeiro de 1996 a março de 1999. Diante disso, optou-se pela escolha de taxas referentes ao custo de oportunidade do capital variando ponto a ponto percentual de $6 \%$ a $20 \%$, para se verificar o efeito do crescimento do custo de oportunidade do capital sobre a avaliação econômica dos projetos de reflorestamento com essências nativas. 
Enfim, neste trabalho, para cada um dos três experimentos selecionados, são criadas alternativas para a composição dos fluxos de caixa. Os projetos com as letras A, P e M referem-se às espécies araruva, pinheiro-brasileiro e pau-marfim, respectivamente. Junto a cada letra, encontram-se números de 1 a 6 . No caso de aquisição das mudas, os números são 1,2 e 3; mas, se o governo decidir doar as mudas - caso de um programa de incentivo ao plantio - esses são 4, 5 ou 6. Além disso, considera-se a possibilidade de incluir no fluxo de caixa a compra da terra ( 1 ou 4$)$, arrendamento da terra ( 2 ou 5 ) ou não incluir o custo referente a terra ( 3 ou 6). Portanto, são dezoito projetos de reflorestamento a serem analisados. $O$ quadro 3 ilustra esses projetos.

Quadro 3 - Tipos de projetos de reflorestamento com essências nativas

\begin{tabular}{|l|c|c|c|c|c|c|}
\hline & \multicolumn{2}{|c|}{ Araruva } & \multicolumn{2}{c|}{ Pinheiro-brasileiro } & \multicolumn{2}{c|}{ Pau-marfim } \\
\cline { 2 - 7 } & $\begin{array}{l}\text { Empresário } \\
\text { compra a } \\
\text { muda }\end{array}$ & $\begin{array}{l}\text { Governo } \\
\text { doa a muda }\end{array}$ & $\begin{array}{l}\text { Empresário } \\
\text { compra a a } \\
\text { muda }\end{array}$ & $\begin{array}{l}\text { Governo } \\
\text { doa a muda }\end{array}$ & $\begin{array}{l}\text { Empresário } \\
\text { compra a a } \\
\text { muda }\end{array}$ & $\begin{array}{l}\text { Governo } \\
\text { doa a muda }\end{array}$ \\
\hline $\begin{array}{l}\text { Empresário } \\
\text { compra a terra }\end{array}$ & A1 & A4 & P1 & P4 & M1 & M4 \\
\hline $\begin{array}{l}\text { Empresário } \\
\text { arrenda a terra }\end{array}$ & A2 & A5 & P2 & P5 & M2 & M5 \\
\hline $\begin{array}{l}\text { Sem incluir o } \\
\text { custo da terra }\end{array}$ & A3 & A6 & P3 & P6 & M3 & M6 \\
\hline
\end{tabular}

\subsection{Escolha dos Métodos de Avaliação Econômica de Projetos ${ }^{8}$}

Os métodos de avaliação econômica de projetos são utilizados para a elaboração de indicadores que expressem de forma simplificada, ou seja, através de valores numéricos, possiveis situações complexas de análise. Após calculados os indicadores, os projetos podem ser ordenados para que sejam selecionados pelos investidores. Como cada indicador se

${ }^{8}$ Seguindo Faro (1972), entende-se por avaliação de um projeto o confronto do número a ser obtido, mediante a aplicação de um dos métodos de avaliação econômica existentes aos fluxos de caixa a ele associados. com um valor numérico obtido exogenamente. Se o resultado desta comparação for favorável, o projeto será dito economicamente viável ou interessante. 
se relaciona com uma dimensão do projeto, considera-se prudente o cálculo e a ordenação de vários indicadores. Usualmente, utilizam-se os seguintes indicadores: "payback" simples, "payback" econômico, custo total atualizado, taxa interna de retorno, relação benefício-custo e valor atual dos fluxos líquidos do projeto (Azevedo Filho, 1995).

O "payback" é um método que calcula o número de anos necessários para que a empresa recupere o capital investido no projeto. Há dois tipos de payback: o simples e o econômico. O payback simples não considera o custo de uso do dinheiro ao longo do tempo, o que é feito no payback econômico. A aplicação de ambos critérios de avaliação, sem restrições, ocorre para os projetos convencionais de investimento cujo fluxo de caixa apresente as seguintes características: $\mathrm{F}_{0}<0$ e $\mathrm{F}_{\mathrm{i}}>0, \mathrm{i}=1, \ldots, \mathrm{n}$, onde $F_{i}$ é o fluxo de caixa no ano $i$. O fluxo de caixa $F_{i}$ é definido por $F_{i}=B_{i}-C_{i}$, onde $B_{i}$ é o fluxo de benefícios e, $C_{i}$, o de custos dos projetos. Se ocorrer mais de uma mudança de sinal no fluxo de caixa líquido, deve-se ter cautela tanto na obtenção quanto na interpretação desse indicador.

A obtenção e existência do "payback" simples (PBS) e do "payback" econômico (PBE) ocorrem quando são satisfeitas as seguintes relações:

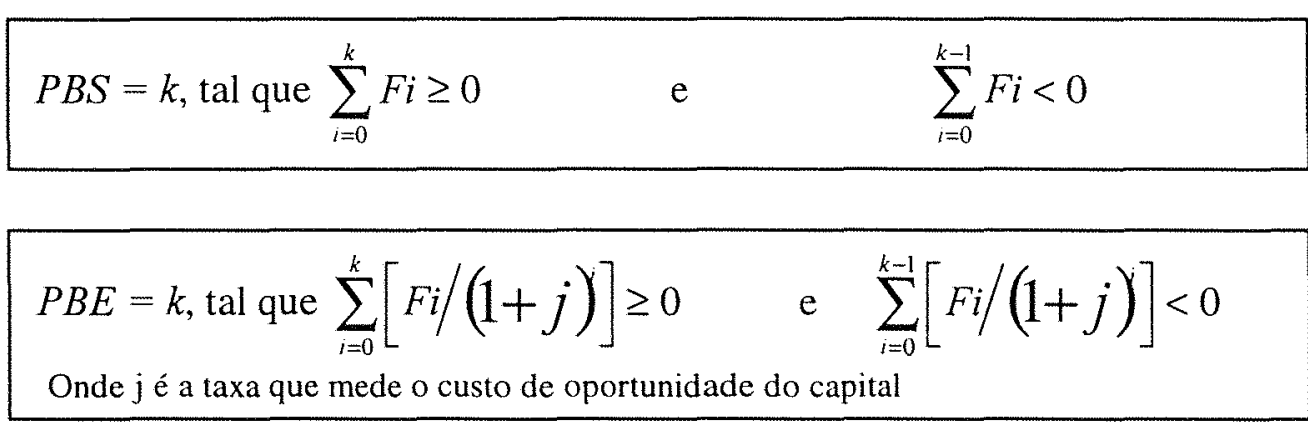

Segundo Noronha (1987), a única vantagem deste método é a simplicidade de cálculo. Mesmo diante das várias desvantagens, esse é muito usado na prática e não deve ser totalmente ignorado. Conforme Azevedo Filho(1995), o "payback" pode ser útil como indicador auxiliar no processo de análise.

Outro método de caráter auxiliar é o custo total atualizado (CTA) ou valor presente dos custos que serve para medir a escala do projeto. O cálculo é o seguinte: 
$C T A=\sum_{i=0}^{n}[C i /(1+j)]$

Onde $C i$ são os custos do projeto no ano i e $j$ é a taxa que mede o custo de oportunidade do capital.

Dentre os métodos de análise mais utilizados, a taxa interna de retorno (TIR) é a mais atrativa, porque a interpretação de seu valor é mais fácil e cômoda para os empresários. A TIR é o valor da taxa de desconto que torna o valor presente do fluxo líquido igual a zero (Noronha, 1987). Este valor será único quando os investimentos forem puros, ou seja, quando o saldo não recuperado do capital não apresenta mudança de sinal no período de duração do projeto; caso contrário há a possibilidade de ocorrência de múltiplas TIR para um mesmo fluxo de caixa. A escolha de um projeto como economicamente viável ocorre se o valor da TIR for superior ao custo de oportunidade do capital. A TIR é definida por:

$$
T I R=\mathrm{r}, \text { tal que } \sum_{i=1}^{n}[(B i-C i) /(1+r)]=0
$$

Onde r é a taxa de desconto. $B i$ e $C i$ são os valores de beneficios e custos no periodo i, respectivamente.

Conforme Noronha (1987), a TIR apresenta duas principais vantagens. A primeira é que ela é calculada internamente a partir do fluxo de caixa do projeto, não sendo necessário supor, a priori, a taxa que mede o custo de oportunidade do capital. A segunda é que ela pode ser comparada diretamente com o custo do capital ou com as alternativas de aplicação no mercado financeiro.

Um indicador muito utilizado e de interpretação relativamente mais fácil do que a dos demais é a relação beneficio-custo (RBC). A RBC é obtida da seguinte forma:

$$
R B C=\frac{\sum_{i=0}^{n}[B i(1+j)]}{\sum_{i=0}^{n}[C i(1+j)]}
$$

Onde $B i$ e Ci são, respectivamente, o beneficio e o custo do projeto em unidades monetárias no ano i; $j$ é a taxa de juro correspondente ao custo de oportunidade do capital. 
A seleção de projetos baseada nesse método se dá pela comparação do valor obtido com a unidade, ou seja, o projeto é descartado se a RBC é menor do que uma unidade. A despeito das suas qualidades, a $\mathrm{RBC}$ apresenta várias limitações, dentre as quais a insensibilidade à escala e à duração do projeto. Além disso, ao contrário da TIR, para se obter a RBC é necessário a fixação, em geral de forma arbitrária, de um custo de oportunidade para ser utilizado como taxa de desconto dos fluxos de beneficios e custos.

De acordo com Azevedo Filho (1995), em condições estritamente deterministas, o mais consistente dos indicadores é o valor atual dos fluxos de rendimentos líquidos de um projeto (VA). Ao contrário da RBC, o VA não apresenta insensibilidade à escala do projeto, mas possui as mesmas limitações observadas para a RBC quanto à duração do projeto e à sensibilidade à taxa de desconto. O VA e o RBC, porém, são afetados de forma diferente quando se altera a taxa de juros. O VA é obtido da seguinte forma:

$$
V A=\sum_{i=0}^{n}\left[(B i-C i) /(1+j)^{j}\right]
$$

Onde $B i$ e Ci são, respectivamente, o beneficio e o custo do projeto em unidades monetárias no ano $i ; \mathrm{e}, j$ é a taxa de juros correspondente ao custo de oportunidade do capital.

O descarte de um projeto através do VA se dá quando o mesmo é menor do que zero. Conclui-se desta fórmula que, independente da capacidade de pagamento da empresa, o mesmo projeto se torna menos atrativo quanto maior for o custo do capital (taxa de desconto). Conforme Faro (1972), a ordenação global de vários projetos de investimento depende da taxa de juros considerada, ou seja, taxas de juros diferentes alteram o valor atual de cada projeto e, por conseqüência, a ordenação dos projetos de investimento.

Além dos indicadores comentados acima, Rodriguez et al. (1997) ressaltam que a análise da viabilidade econômica de projetos de reflorestamento pode ser feita usando a fórmula de Faustmann (que surgiu em1849) ou valor esperado da terra (VET). Neste caso, este indicador é apropriado para os projetos cujos ciclos de produção se perpetuam. Assim, um projeto será considerado viável se o VET for superior ao custo de aquisição da terra 
(CAT). Quanto maior for a relação VET/CAT, mais atrativo será o projeto. Conforme Clutter et al.(1983), o VET pode ser obtido pela seguinte expressão:

$\mathrm{VET}=R L t /[(1+j)-1]$

Onde: VET é o valor esperado da terra; RLt é a receita líquida capitalizada no momento final de cada ciclo de produção; t é a duração de cada ciclo de produção; e, j é a taxa que mede o custo de oportunidade do capital.

Diante dos vários aspectos associados aos projetos e considerando as diferentes abrangências dos indicadores, optou-se, na medida do possível, pela utilização de todos os métodos discutidos acima. Com isso, procura-se dar mais subsídios à tomada de decisão dos investidores.

A análise dos indicadores acima mencionados pode ser feita em condições deterministas ou em condições de risco.

Em condições deterministas, calcula-se os valores de VA, RBC, TIR, PBS, PBE, CTA E VET para determinado período de tempo. A disponibilidade de informações (ver apêndices 5, 6,7), nos permite considerar apenas o mês de março de 1999 como referência. O cálculo dos valores dos indicadores, exceto do VET, dos projetos de final 1, 2, 4 ou 5 é feito com o auxílio do programa computacional DETERPRJ ${ }^{9}$. Os casos de final 3 ou 6 são analisados no VET, pois seus resultados distorcem os outros indicadores. O VET será calculado a partir do software MICROSOFT EXCEL.

A análise em condições de risco é feita em duas etapas. A primeira consiste na avaliação da sensibilidade da TIR e do VA à mudanças nas seguintes variáveis: produtividade, preço da tora, preço da terra e custo de implantação do reflorestamento. Devido a limitações, de espaço e tempo, considerou-se apenas os projetos de tipo 1 (compra da terra e de mudas) para efeito da análise de sensibilidade.

O segundo tipo de análise de risco é a avaliação dos valores de TIR, VA, RBC, PBS,

9 Para mais detalhes veja Azevedo Filho (1988). 
principais variáveis que afetam o fluxo de caixa tenham distribuição triangular de suas probabilidades (ver Noronha, 1987, sobre este tipo de distribuição de probabilidade).

\subsection{Estimativas dos Indicadores de Avaliação para os Projetos Selecionados - a análise determinista}

No sub-item 5.2 viu-se que, em condições estritamente deterministas, o indicador mais consistente é o valor atual (VA). Na tabela 5 são apresentados os valores atuais dos projetos descritos no quadro 3 , em relação às várias alternativas de custo de oportunidade do capital. Para este indicador, os projetos que apresentam valores negativos são descartados. Realmente, pode-se constatar que o VA é sensivel à mudança na taxa de juros tanto na seleção quanto na ordenação dos projetos.

Tabela 5 - Valores Atuais (VA) dos projetos de reflorestamento, em R\$/ha, considerando o custo de oportunidade do capital variando entre $6 \%$ e $20 \%$ ao ano - situação em março de 1999

\begin{tabular}{|c|c|c|c|c|c|c|c|c|c|c|c|c|c|c|c|}
\hline \multirow{2}{*}{$\begin{array}{l}\text { Proje- } \\
\text { tos }\end{array}$} & \multicolumn{15}{|c|}{ Custo de oportunidade do capital (\%) } \\
\hline & 6 & 7 & 8 & 9 & 10 & 11 & 12 & 13 & 14 & 15 & 16 & 17 & 18 & 19 & 20 \\
\hline M1 & 2469 & 1341 & 456 & -240 & -788 & -1220 & -1561 & -1832 & -2046 & -2216 & -2351 & -2459 & -2544 & -2612 & -2666 \\
\hline M2 & 2363 & 1437 & 720 & 166 & -262 & -593 & -848 & -1044 & -1194 & -1308 & -1394 & -1458 & -1505 & -1539 & .1562 \\
\hline M4 & 3188 & 2060 & 1175 & 480 & -68 & -500 & -842 & -1112 & -1327 & -1497 & -1632 & -1739 & -1825 & -1893 & -1947 \\
\hline M5 & 3083 & 2157 & 1440 & 886 & 457 & 126 & -129 & -325 & -474 & -588 & -674 & -738 & -785 & -819 & .843 \\
\hline P1 & 3353 & 2096 & 1111 & 348 & -270 & -749 & -1126 & -1425 & -1660 & -1848 & -1996 & -2113 & -2207 & -2281 & -2339 \\
\hline $\mathrm{P2}$ & 3247 & 2192 & 1376 & 744 & 255 & -122 & -413 & -637 & -809 & -939 & -1038 & -1113 & -1167 & -1207 & -1235 \\
\hline P4 & 3759 & 2501 & 1517 & 744 & 136 & -343 & -720 & -1019 & -1255 & -1442 & -1590 & -1708 & -1801 & -1875 & -1934 \\
\hline P5 & 3653 & 2598 & 1781 & 1150 & 661 & 284 & -7 & -231 & -403 & -534 & -633 & -707 & -762 & -801 & -830 \\
\hline A1 & 4893 & 3226 & 1917 & 888 & 76 & -565 & -1072 & -1475 & -1794 & -2049 & -2251 & -2413 & -2542 & -2645 & -2728 \\
\hline$A 2$ & 4787 & 3322 & 2182 & 1294 & 601 & 61 & -359 & -687 & -942 & -1140 & -1294 & -1412 & -1503 & -1572 & -1624 \\
\hline A4 & 5890 & 4223 & 2915 & 1885 & 1074 & 432 & -75 & -477 & -797 & -1051 & -1254 & -1416 & -1545 & -1648 & -1731 \\
\hline A5 & 5785 & 4319 & 3179 & 2291 & 1599 & 1059 & 638 & 310 & 55 & -143 & -297 & 415 & -506 & -575 & -627 \\
\hline
\end{tabular}

Fonte: valores calculados pelo autor a partir dos dados do apêndice 4

Quando a taxa de juros é de $6 \%$ ao ano, todos os projetos de reflorestamento com essências nativas aqui analisados são considerados viáveis economicamente, pois seus valores 
atuais são maiores do que zero. É possivel observar três critérios que regem a ordenação desses projetos, por ordem decrescente de importância: espécie, aquisição/doação de mudas e fator terra. Pelo critério da espécie, os melhores projetos são aqueles com a araruva (A), seguidos daqueles com o pinheiro-brasileiro (P) e o pau-marfim (M). Pelo critério doação/aquisição de mudas, os projetos com mudas doadas (4 e 5) são melhores em relação aqueles nos quais as mudas são adquiridas ( 1 e 2). E, pelo terceiro critério, os projetos nos quais se compra a terra ( 1 e 4 ) são melhores do que aqueles nos quais se arrenda a terra ( 2 e 5) à taxa de juros de $6 \%$, ocorrendo o inverso à medida que a taxa de juros sobe.

Por outro lado, o crescimento do custo de oportunidade do capital provoca algumas alterações na seleção e ordenação dos projetos. O primeiro projeto a ser rejeitado é o M1 - quando a taxa de juros é $9 \%$ - e, quando a taxa é $15 \%$, todos os projetos são rejeitados. Os critérios de ordenação dos projetos também se modificam e, quanto maior for a taxa de juros, maior é a tendência para que os projetos sejam ordenados na seguinte seqüência numérica (dos melhores para os piores): $5,2,4$ e 1 . O que não é afetado pela taxa de juros é a relação entre os projetos que consideram a doação ou a aquisição de mudas quando os outros critérios são mantidos constantes, ou seja, M4 é preferível a M1, M5 a M2, P4 a P1, P5 a P2, A4 a A1 e A5 a A2. Além disso, os projetos que consideraram a doação de mudas pelo governo foram considerados viáveis economicamente com taxas de juros de 1 a 3 pontos percentuais maiores do que a máxima taxa no qual são aconselhados os projetos com aquisição de mudas.

As estimativas da rentabilidade dos projetos pelo método de avaliação da relação beneficio/custo (RBC) estão contidas na tabela 6. Os projetos com valores menores ou iguais a unidade são considerados inviáveis economicamente. Pode-se observar que, em relação a seleção, este método é consistente com o VA, ou seja, os projetos rejeitados pelo VA são os mesmos rejeitados pelo RBC. A ordenação segundo os dois métodos é, porém, diferente. Se a taxa de juros é $6 \%$ não existe um critério para a ordenação dos projetos pela $\mathrm{RBC}$, mas quanto maior for a taxa de juros, os mesmos comentários feitos para o VA são válidos para o RBC. Apesar do RBC ser menos consistente em relação ao VA, optou-se pela 
apresentação desse indicador face a sua grande utilização e interpretação relativamente fácil, conforme Azevedo Filho (1995).

Tabela 6 - Relações Benefício/Custo (RBC) dos projetos de reflorestamento considerando o custo de oportunidade do capital variando entre $6 \%$ e $20 \%$ ao ano - situação em março de 1999

\begin{tabular}{l|c|c|c|c|c|c|c|c|c|c|c|c|c|c|c}
\hline & \multicolumn{10}{|c|}{} & \multicolumn{10}{|c|}{ Custo de oportunidade do capital (\%) } \\
\cline { 2 - 15 } & 6 & 7 & 8 & 9 & 10 & 11 & 12 & 13 & 14 & 15 & 16 & 17 & 18 & 19 & 20 \\
\hline M1 & 1,79 & 1,43 & 1,15 & 0,92 & 0,74 & 0,60 & 0,48 & 0,39 & 0,32 & 0,26 & 0,21 & 0,17 & 0,14 & 0,11 & 0,09 \\
\hline M2 & 1,83 & 1,53 & 1,28 & 1,07 & 0,89 & 0,74 & 0,62 & 0,51 & 0,43 & 0,35 & 0,29 & 0,25 & 0,20 & 0,17 & 0,14 \\
\hline M5 & 2,32 & 1,86 & 1,50 & 1,20 & 0,97 & 0,78 & 0,63 & 0,51 & 0,42 & 0,34 & 0,28 & 0,23 & 0,18 & 0,15 & 0,12 \\
\hline P1 & 2,45 & 2,09 & 1,78 & 1,51 & 1,28 & 1,08 & 0,91 & 0,77 & 0,65 & 0,55 & 0,46 & 0,39 & 0,33 & 0,28 & 0,24 \\
\hline P2 & 2,28 & 1,92 & 1,61 & 1,35 & 1,12 & 0,94 & 0,78 & 0,65 & 0,54 & 0,45 & 0,38 & 0,31 & 0,26 & 0,22 & 0,18 \\
\hline P4 & 2,56 & 2,05 & 1,64 & 1,32 & 1,06 & 0,85 & 0,69 & 0,55 & 0,45 & 0,36 & 0,29 & 0,24 & 0,20 & 0,16 & 0,13 \\
\hline P5 & 2,72 & 2,31 & 1,96 & 1,66 & 1,40 & 1,18 & 0,99 & 0,84 & 0,70 & 0,59 & 0,50 & 0,42 & 0,35 & 0,29 & 0,25 \\
\hline A1 & 2,47 & 1,98 & 1,59 & 1,27 & 1,02 & 0,82 & 0,67 & 0,54 & 0,44 & 0,35 & 0,29 & 0,24 & 0,19 & 0,16 & 0,13 \\
\hline A2 & 2,57 & 2,15 & 1,79 & 1,49 & 1,23 & 1,02 & 0,85 & 0,71 & 0,59 & 0,49 & 0,40 & 0,34 & 0,28 & 0,23 & 0,19 \\
\hline A4 & $\mathbf{3 , 5 4}$ & 2,84 & 2,28 & 1,84 & 1,48 & 1,19 & 0,97 & 0,78 & 0,64 & 0,52 & 0,42 & 0,34 & 0,28 & 0,23 & 0,19 \\
\hline A5 & $\mathbf{3 , 8 3}$ & 3,28 & 2,80 & $\mathbf{2 , 3 8}$ & 2,02 & 1,72 & 1,46 & 1,23 & 1,04 & 0,88 & 0,75 & 0,63 & 0,53 & 0,45 & 0,38 \\
\hline \hline
\end{tabular}

Fonte: valores calculados pelo autor a partir dos dados do apêndice 4

Analisando-se os fluxos de caixa dos projetos (apêndice 4), observa-se que todos são do tipo não-convencional, o que implica em maior cautela na utilização do método da taxa interna de retorno (TIR). No entanto, verifica-se também que não há nenhuma mudança no saldo não-recuperado dos projetos, classificando-os como investimentos do tipo puro. Com isso, os projetos analisados apresentam TIR única. Na tabela 7 são apresentados os valores da TIR dos projetos de reflorestamento selecionados.

Tabela 7 - Taxas Internas de Retorno (TIR) dos projetos de reflorestamento - situação em março de 1999

\begin{tabular}{c|r|c|r|r|r}
\hline Projeto & \multicolumn{1}{|c|}{ TIR } & Projeto & \multicolumn{1}{c|}{ TIR } & Projeto & \multicolumn{1}{c}{ TIR } \\
\hline M1 & 8,63 & P1 & 9,53 & A1 & 10,11 \\
\hline M2 & 9,36 & P2 & 10,65 & A2 & 11,13 \\
\hline M4 & 9,86 & P4 & 10,26 & A4 & 11,84 \\
\hline M5 & 11,46 & P5 & 11,97 & A5 & 14,25 \\
\hline
\end{tabular}

Fonte: valores calculados pelo autor a partir dos dados do apêndice 4 
Se os valores da TIR dos projetos forem comparados aos custos de oportunidade do capital utilizados para o cálculo do VA, constata-se que os dois métodos rejeitam os mesmos projetos. No entanto, a ordenação dos projetos pela TIR e pelo VA não coincidem para nenhuma das taxas de juros utilizadas.

As estimativas do custo total atualizado (CTA) estão contidas na tabela 8. Este critério serve para a auxiliar a decisão do investidor considerando restrições orçamentárias. Por exemplo, para uma taxa de juros de $6 \%$ ao ano, o projeto $\mathrm{A} 4$ seria viável economicamente e o preferivel pelo método do VA, mas se o investidor possui recursos inferiores ao custo total atualizado ( $\mathrm{R} \$ 2.322,00)$, então este projeto deverá ser descartado.

Tabela 8 - Custos Totais Atualizados (CTA) dos projetos de reflorestamento, em R\$/ha, considerando o custo de oportunidade do capital variando entre 6\% e 20\% ao ano - situação em março de 1999

\begin{tabular}{|c|c|c|c|c|c|c|c|c|c|c|c|c|c|c|c|}
\hline & \multicolumn{15}{|c|}{ Custo de oportunidade do capital (\%) } \\
\hline & 6 & 7 & 8 & 9 & 10 & 11 & 12 & 13 & 14 & 15 & 16 & 17 & 18 & 19 & 20 \\
\hline M1 & 3126 & 3102 & 3081 & 3062 & 3045 & 3030 & 3017 & 3004 & 2993 & 2983 & 2974 & 2965 & 2957 & 2950 & 2943 \\
\hline M2 & 2847 & 2701 & 2575 & 2464 & 2368 & 2282 & 2206 & 2139 & 2079 & 2025 & 1976 & 1932 & 1892 & 1855 & 1822 \\
\hline M4 & 2407 & 2383 & 2362 & 2343 & 2326 & 2311 & 2297 & 2285 & 2274 & 2264 & 2254 & 2246 & 2238 & 2230 & 2223 \\
\hline M5 & 2127 & 1982 & 1855 & 1745 & 1648 & 1562 & 1487 & 1419 & 1359 & 1305 & 1256 & 1212 & 1172 & 1135 & 1102 \\
\hline Pl & 2812 & 2788 & 2767 & 2748 & 2731 & 2716 & 2703 & 2690 & 2679 & 2669 & 2660 & 2651 & 2643 & 2636 & 2629 \\
\hline $\mathrm{P} 2$ & 2533 & 2387 & 2261 & 2151 & 2054 & 1968 & 1892 & 1825 & 1765 & 1711 & 1662 & 1618 & 1578 & 1541 & 1508 \\
\hline $\mathrm{P4}$ & 2407 & 2382 & 2361 & 2342 & 2325 & 2310 & 2297 & 2285 & 2274 & 2263 & 2254 & 2245 & 2237 & 2230 & 2223 \\
\hline P5 & 2127 & 1982 & 1855 & 1745 & 1648 & 1562 & 1487 & 1419 & 1359 & 1305 & 1256 & 1212 & 1172 & 1135 & 1102 \\
\hline $\mathrm{A} 1$ & 3319 & 3295 & 3274 & 3255 & 3238 & 3223 & 3209 & 3197 & 3186 & 3176 & 3166 & 3158 & 3150 & 3143 & 3136 \\
\hline$A 2$ & 3040 & 2894 & 2768 & 2657 & 2560 & 2475 & 2399 & 2332 & 2272 & 2217 & 2169 & 2125 & 2084 & 2048 & 2014 \\
\hline A4 & 2322 & 2298 & 2776 & 2257 & 2241 & 2226 & 2212 & 2200 & 2189 & 2178 & 2169 & 2160 & 2153 & 2145 & 2138 \\
\hline$\overline{A 5}$ & 2042 & 1897 & 1770 & 1660 & 1563 & 1477 & 1402 & 1334 & 1274 & 1220 & 1171 & 1127 & 1087 & 1050 & 1017 \\
\hline
\end{tabular}

Fonte: valores calculados pelo autor a partir dos dados do apêndice 4

Dentre os indicadores que medem o tempo de retorno do capital investido, o payback simples (PBS) foi de 25 anos para os projetos selecionados (final 1, 2, 4 ou 5). Já o payback econômico (PBE) foi de 25 anos para todos os projetos que apresentaram valor atual (VA) positivo e não foi determinado para os projetos com VA nulo ou negativo. Se comparado aos métodos do VA e da TIR, os projetos descartados pelo PBE são os mesmos em relação aos outros dois métodos. 
Na tabela 9 são apresentados os valores esperados da terra (VET) para os projetos cujos fluxos de caixa não incluem o custo de aquisição ou o arrendamento da terra. Além dos projetos já analisados, incluiu-se o projeto E1 (plantio do eucalipto para celulose) a fim de compará-lo com os outros. Os projetos cujo VET é menor do que o custo de aquisição da terra (CAT), ou seja, CAT igual a R\$1.652,89/ha, são inviáveis economicamente

Tabela 9 - Valores Esperados da Terra (VET) dos projetos de reflorestamento considerando o custo de oportunidade do capital variando entre $6 \%$ e $20 \%$ ao ano - em março de 1999

\begin{tabular}{l|r|r|r|r|r|r|r|r|r|r|r|r|r|r|r}
\hline \multirow{2}{*}{} & \multicolumn{10}{|c|}{ Custo de oportunidade do capital (\%) } \\
\cline { 2 - 15 } & 6 & 7 & 8 & 9 & 10 & 11 & 12 & 13 & 14 & 15 & 16 & 17 & 18 & 19 & 20 \\
\hline M3 & 4871 & 3296 & 2186 & 1381 & 785 & 336 & -6 & -270 & -474 & -408 & -490 & -556 & -608 & -651 & -1042 \\
\hline M6 & 5809 & 4178 & 3029 & 2195 & 1578 & 1112 & 758 & 486 & 274 & 71 & -13 & -79 & -131 & -173 & -314 \\
\hline P3 & 6038 & 4357 & 2965 & 2045 & 1365 & 853 & 463 & 164 & -67 & -160 & -252 & -324 & -382 & -428 & -709 \\
\hline P6 & 6567 & 4732 & 3440 & 2504 & 1812 & 1291 & 895 & 590 & 354 & 110 & 17 & -55 & -113 & -159 & -299 \\
\hline A3 & 8031 & 5606 & 3897 & 2656 & 1736 & 1043 & 513 & 105 & -212 & -297 & -424 & -527 & -607 & -673 & -1104 \\
\hline A6 & 9331 & 6829 & 5065 & 3785 & 2835 & 2119 & 1573 & 1152 & 824 & 367 & 238 & 135 & 54 & -11 & -96 \\
\hline E1 & 5339 & 4114 & 3191 & 2468 & 1887 & 1408 & 1007 & 665 & 371 & 115 & -110 & -309 & -487 & -646 & -789 \\
\hline
\end{tabular}

Fonte: valores calculados pelo autor, considerando as informações do apêndice 4 .

Quando a taxa de juros é de 6\% ao ano, todos os projetos de reflorestamento com essências nativas aqui analisados são considerados viáveis economicamente. A ordenação, com exceção do projeto El, segue dois critérios: espécie e aquisição/doação de mudas. Pelo primeiro critério, o da espécie, os melhores projetos são aqueles com a araruva (A), seguidos daqueles com o pinheiro-brasileiro (P) e o pau-marfim (M). Pelo critério doação/aquisição de mudas, os projetos com mudas doadas (tipo 6) são melhores em relação aqueles nos quais as mudas são adquiridas (tipo 3 ).

Quando o custo de oportunidade do capital começa a se elevar, o primeiro projeto a ser rejeitado é o M3 e, quando a taxa de juros é de $12 \%$, todos são rejeitados inclusive E1, pois VET < CAT. Por outro lado, o desempenho dos reflorestamentos com as essências nativas comparado ao do eucalipto (E1) é bastante sensível a mudança na taxa de juros. Quando esta é $6 \%$ ou $7 \%$, o VET do projeto E1 só é superior ao do projeto M3. Para as 
taxas de $8 \%$ e $9 \%$, o VET do projeto E1 é superior aos dos projetos M3, M6 e P3. Quando a taxa é $10 \%$, somente o VET de A6 é superior ao de E1 e, em $11 \%$, o projeto E1 seria rejeitado, mas não o $\mathrm{A} 6$.

\subsection{O impacto de novos cenários sobre os indicadores de rentabilidade - a análise de sensibilidade}

Uma das formas mais simples de introduzir o risco numa análise de investimento é através da análise de sensibilidade das variáveis. Utilizando-se das informações disponiveis sobre os experimentos e pela consulta aos técnicos atuantes na área de reflorestamento (pinus e eucalipto), foram construídos possíveis cenários otimistas e pessimistas para os reflorestamentos com essências nativas. Esses cenários, utilizados para as novas estimativas dos principais indicadores considerados (VA e TIR), visam dar mais subsídios para a tomada de decisão dos investidores. No quadro 4 estão os resultados para valor atual calculado com taxa de juros de $6 \%$ ao ano e TIR.

No Quadro 4 observa-se que o aumento da produtividade é a variável com maior impacto na melhoria das estimativas dos indicadores. Os valores atuais dos projetos $\mathrm{M} 1$ *, $\mathrm{P}^{*}$ e A1* são, respectivamente, $52,77 \%, 86,20 \%$ e $61,56 \%$ maiores do que os dos projetos M1, P1 e A1 (Tabela 5$)^{10}$, para a taxa de juros de $6 \%$ ao ano. Já os valores da TIR dos projetos $\mathrm{M}^{*}$, $\mathrm{P}^{*}$ e $\mathrm{A} 1^{*}$ são, respectivamente, $11,12 \%, 18,47 \%$ e $14,34 \%$ maiores do que os valores da TIR dos projetos M1, P1 e A1 (Tabela 7).

Por outro lado, observa-se que a diminuição no preço da tora, em função da qualidade inferior da madeira, é a variável com maior impacto na deterioração das estimativas dos indicadores. Neste caso, os valores atuais dos projetos $\mathrm{M} 1 *, \mathrm{P}^{*}$ e $\mathrm{A} 1^{*}$ são, respectivamente, $79,18 \%, 66,46 \%$ e $61,05 \%$ menores do que os dos projetos $\mathrm{M} 1$, P1 e A1 (Tabela 5), para a taxa de juros de $6 \%$ ao ano. Já os valores da TIR dos projetos $\mathrm{M}^{*}, \mathrm{P} 1^{*}$ e Al* são, respectivamente, $22,48 \%, 21,20 \%$ e $20,28 \%$ menores do que os valores da TIR

10 Os valores da tabela 5 estão aproximados, enquanto as diferenças percentuais foram obtidas dos valores exatos. 
dos projetos M1, P1 e Al (Tabela 7).

Observa-se que a maior redução na rentabilidade dos projetos de reflorestamento com nativas advém do uso do material genético não homogêneo, o que leva à heterogeneidade de certas características desejáveis da madeira. Isto sinaliza para a importância da intensificação das pesquisas nessa área.

Quadro 4 - Valor Atual (VA), Taxa Interna de Retorno (TIR) e variação percentual em relação à análise determinista, para os projetos $\mathrm{Ml}^{*}, \mathrm{P}^{*}$ e $\mathrm{Al}{ }^{*}$ (novos cenários) - situação em março de 1999

\begin{tabular}{|c|c|c|c|c|c|c|c|}
\hline \multirow[t]{2}{*}{ Cenário } & \multirow[t]{2}{*}{ Variável } & \multirow[t]{2}{*}{$\begin{array}{l}\text { Variação } \\
\text { percentual } \\
\text { da variável }\end{array}$} & \multirow[t]{2}{*}{ Projeto } & \multirow[t]{2}{*}{$\begin{array}{c}\mathrm{VA} \\
\text { (R\$/ha) }\end{array}$} & \multirow[t]{2}{*}{$\begin{array}{l}\text { TIR } \\
(\%)\end{array}$} & \multicolumn{2}{|c|}{$\begin{array}{l}\text { Variação percentual em } \\
\text { relação à análise } \\
\text { determinista }\end{array}$} \\
\hline & & & & & & VA & TIR \\
\hline \multirow{12}{*}{ Otimista } & \multirow[t]{3}{*}{ Produtividade } & 25,00 & $\mathrm{M} 1^{*}$ & 3771,46 & 9,59 & 52,77 & 11,12 \\
\hline & & 50,00 & $\mathrm{P} 1 *$ & 6242,95 & 11,29 & 86,20 & 18,47 \\
\hline & & 38,48 & $\mathrm{~A} 1^{*}$ & 7904,67 & 11,56 & 61,56 & 14,34 \\
\hline & \multirow{3}{*}{$\begin{array}{l}\text { Preço da tora } \\
\text { (certificada) }\end{array}$} & 10,00 & $\mathrm{M1}^{*}$ & 2957,46 & 9,01 & 19,79 & 4,40 \\
\hline & & 10,00 & P1* & 3909,88 & 9,92 & 16,61 & 4,09 \\
\hline & & 10,00 & $\mathrm{~A} 1 *$ & 5639,78 & 10,50 & 15,27 & 3,86 \\
\hline & \multirow[t]{3}{*}{ Preço da terra } & 25,00 & M1* & 2785,71 & 9,21 & 12,84 & 6,72 \\
\hline & & 25,00 & $\mathrm{P} 1 *$ & 3669,78 & 10,20 & 9,45 & 7,03 \\
\hline & & 25,00 & $\mathrm{Al}^{*}$ & 5209,74 & 10,69 & 6,48 & 5,74 \\
\hline & \multirow{3}{*}{$\begin{array}{l}\text { Custo de } \\
\text { implantação }\end{array}$} & $-68,70$ & $\mathrm{M1}^{*}$ & 2963,52 & 9,44 & 20,04 & 9,39 \\
\hline & & $-44,60$ & $\mathrm{P}^{*}$ & 3533,63 & 9,84 & 5,39 & 3,25 \\
\hline & & $-85,60$ & $\mathrm{Al}^{*}$ & 5746,19 & 11,54 & 17,44 & 14,14 \\
\hline \multirow{6}{*}{ Pessimista } & \multirow{3}{*}{$\begin{array}{l}\text { Preço da tora } \\
\text { (frete menor) }\end{array}$} & $-33,00$ & M1* & 1563,68 & 7,83 & $-36,67$ & $-9,27$ \\
\hline & & $-33,00$ & $\mathrm{Pl}^{*}$ & 3034,03 & 9,29 & $-26,67$ & $-7,45$ \\
\hline & & $-33,00$ & A.* & 3578,40 & 9,32 & $-27,13$ & $-7,91$ \\
\hline & \multirow{3}{*}{\begin{tabular}{|l|} 
Preço da tora \\
(qualidade \\
inferior)
\end{tabular}} & $-40,00$ & M1* & 514,03 & 6,69 & $-79,18$ & $-22,48$ \\
\hline & & $-40,00$ & $\mathrm{P} 1 *$ & 1124,66 & 7,51 & $-66,46$ & $-21,20$ \\
\hline & & $-40,00$ & $\mathrm{Al}^{*}$ & 1905,53 & 8,06 & $-61,05$ & $-20,28$ \\
\hline
\end{tabular}

Fonte: Apêndice 8 e valores calculados pelo autor.

Os resultados do quadro 4 demonstram que, mesmo em cenários pessimistas, os reflorestamentos homogêneos com espécies nativas são rentáveis. 


\subsection{As estimativas dos indicadores de avaliação para os projetos selecionados - a} análise de risco pela simulação de Monte Carlo

A despeito das poucas informações sobre o reflorestamento com as essências nativas selecionadas, a maior sofisticação da análise em condição de risco pelo método de Monte Carlo enriquece a atual análise de rentabilidade dos projetos. Para o presente caso, foi considerado o custo de oportunidade mínimo de $6 \%$ ao ano e os limites utilizados como referência foram aqueles obtidos pela análise determinista para os projetos A1, P1 e M1.

Pelas estimativas obtidas pelo método do VA, nas tabelas 10 a 15 , os projetos com nativas são ainda mais atrativos quando comparados com as estimativas da análise determinista. Pelo método da TIR observa-se que em vários casos, as estimativas para os casos de arrendamento da terra são inferiores as respectivas estimativas obtidas pela análise determinista.

A fim de se comparar com resultados obtidos por outros autores, também se considerou as estimativas dos indicadores para o caso de não se incluir o custo da terra. Neste caso, as estimativas da TIR variaram de 15,2\% com desvio-padrão de 1,3 ponto percentual (tabela 12 - plantio do pau-marfim com aquisição de mudas) a 22,2\% com desvio-padrão de 1,5 ponto percentual (tabela 11 - plantio da araruva com doação de mudas). Comparando-se com outras atividades apresentadas no quadro 5, o reflorestamento com nativas mostra-se bastante competitiva, principalmente para o plantio da araruva.

Quadro 5 - Taxa interna de retorno média (TIR) e desvio-padrão (DSP) para projetos na agricultura e criação animal

\begin{tabular}{|l|l|l|l|}
\hline Projeto & TIR & DSP & Referência \\
\hline $\begin{array}{l}\text { Atividades relacionadas a agricultura e } \\
\text { criação animal }\end{array}$ & 0,115 & 0,103 & Contador (1981) \\
\hline Pomar de laranjeira (com declínio) & 0,180 & 0,038 & Azevedo Filho (1988) \\
\hline Pomar de laranjeira (sem declínio) & 0,192 & 0,034 & Azevedo Filho (1988) \\
\hline Seringal (cenário otimista) & 0,196 & 0,021 & Takitane (1988) \\
\hline Seringal (cenário pessimista) & 0,144 & 0,019 & Takitane (1988) \\
\hline
\end{tabular}


Tabela 10 - Indicadores de rentabilidade considerando análise de risco para plantio de araruva com aquisição de mudas

\begin{tabular}{|c|c|c|c|c|c|c|}
\hline Especificação & Indicador & Média & Desvio-padrão & Limite (L) & $\mathrm{P}(\mathrm{I}>\mathrm{L})$ & N.S. \\
\hline \multirow{6}{*}{$\begin{array}{l}\text { Compra a terra } \\
\text { e compra as } \\
\text { mudas } \\
\text { (A1) }\end{array}$} & TIR & 0.113 & 0.014 & 0.101 & 0.810 & 0 \\
\hline & $\mathrm{VA}$ & 12396.026 & 4340.268 & 4893.000 & 0.980 & 0 \\
\hline & RBC & 3.424 & 1.056 & 2.470 & 0.830 & 0 \\
\hline & PBS & 25.000 & 0.000 & 25.000 & 0.000 & 0 \\
\hline & PBE & 25.000 & 0.000 & 25.000 & 0.000 & 0 \\
\hline & CTA & 5388.577 & 1077.920 & 3319.000 & 0.985 & 0 \\
\hline \multirow{6}{*}{$\begin{array}{l}\text { Arrenda a } \\
\text { terra e compra } \\
\text { as mudas } \\
\text { (A2) }\end{array}$} & TIR & 0.115 & 0.018 & 0.101 & 0.760 & 0 \\
\hline & $\mathrm{VA}$ & 10206.459 & 4474.070 & 4893.000 & 0.875 & 0 \\
\hline & $\mathrm{RBC}$ & 2.614 & 0.841 & 2.470 & 0.530 & 0 \\
\hline & PBS & 25.000 & 0.000 & 25.000 & 0.000 & 0 \\
\hline & $\mathrm{PBE}$ & 25.000 & 0.000 & 25.000 & 0.000 & 0 \\
\hline & CTA & 6703.166 & 1274.551 & 3319.000 & 1.000 & 0 \\
\hline \multirow{6}{*}{$\begin{array}{l}\text { Sem o custo } \\
\text { da Terra e com } \\
\text { compra de } \\
\text { mudas (A3) }\end{array}$} & TIR & 0.169 & 0.014 & 0.101 & 1.000 & 0 \\
\hline & $\mathrm{VA}$ & 15269.638 & 4619.870 & 4893.000 & 1.000 & 0 \\
\hline & $\mathrm{RBC}$ & 10.367 & 2.973 & 2.470 & 1.000 & 0 \\
\hline & PBS & 25.000 & 0.000 & 25.000 & 0.000 & 0 \\
\hline & PBE & 25.000 & 0.000 & 25.000 & 0.000 & 0 \\
\hline & CTA & 1640.478 & 99.780 & 3319.000 & 0.000 & 0 \\
\hline
\end{tabular}

Fonte: valores calculados pelo autor pela simulação de Monte Carlo

Tabela 11 - Indicadores de rentabilidade considerando análise de risco para plantio de araruva com doação de mudas pelo governo

\begin{tabular}{|c|c|c|c|c|c|c|}
\hline Especificação & Indicador & Média & Desvio-padrāo & Limite(L) & $\mathrm{P}(\mathrm{I}>\mathrm{L})$ & N.S. \\
\hline \multirow{6}{*}{$\begin{array}{l}\text { Compra a terra } \\
\text { e as mudas são } \\
\text { doadas pelo } \\
\text { governo } \\
\text { (A4) }\end{array}$} & TIR & 0.122 & 0.017 & 0.101 & 0.890 & 0 \\
\hline & VA & 13159.288 & 4881.478 & 4893.000 & 0.995 & 0 \\
\hline & RBC & 4.231 & 1.635 & 2.470 & 0.905 & 0 \\
\hline & PBS & 25.000 & 0.000 & 25.000 & 0.000 & 0 \\
\hline & PBE & 25.000 & 0.000 & 25.000 & 0.000 & 0 \\
\hline & CTA & 4447.676 & 1074.552 & 3319.000 & 0.830 & 0 \\
\hline \multirow{6}{*}{$\begin{array}{l}\text { Arrenda a } \\
\text { Terra e as } \\
\text { mudas são } \\
\text { doadas pelo } \\
\text { governo } \\
\text { (A5) } \\
\end{array}$} & TIR & 0.126 & 0.020 & 0.101 & 0.905 & 0 \\
\hline & $\mathrm{VA}$ & 10506.182 & 4555.982 & 4893.000 & 0.925 & 0 \\
\hline & $\mathrm{RBC}$ & 2.971 & 1.104 & 2.470 & 0.615 & 0 \\
\hline & PBS & 25.000 & 0.000 & 25.000 & 0.000 & 0 \\
\hline & PBE & 25.000 & 0.000 & 25.000 & 0.000 & 0 \\
\hline & CTA & 5753.418 & 1313.844 & 3319.000 & 0.990 & 0 \\
\hline \multirow{6}{*}{$\begin{array}{l}\text { Sem o custo } \\
\text { da terra e as } \\
\text { mudas são } \\
\text { doadas pelo } \\
\text { governo } \\
\text { (A6) } \\
\end{array}$} & TIR & 0.222 & 0.015 & 0.101 & 1.000 & 0 \\
\hline & $\mathrm{VA}$ & 15779.687 & 4777.043 & 4893.000 & 1.000 & 0 \\
\hline & $\mathrm{RBC}$ & 23.555 & 6.889 & 2.470 & 1.000 & 0 \\
\hline & PBS & 18.655 & 4.115 & 25.000 & 0.000 & 0 \\
\hline & PBE & 25.000 & 0.000 & 25.000 & 0.000 & 0 \\
\hline & CTA & 701.483 & 40.993 & 3319.000 & 0.000 & 0 \\
\hline
\end{tabular}

Fonte: valores calculados pelo autor pela simulação de Monte Carlo 
Tabela 12 - Indicadores de rentabilidade considerando análise de risco para plantio de paumarfim, com aquisição de mudas

\begin{tabular}{|c|c|c|c|c|c|c|}
\hline Especificação & Indicador & Média & Desvio-padrão & Limite (L) & $\mathrm{P}(\mathrm{I}>\mathrm{L})$ & N.S. \\
\hline \multirow{6}{*}{$\begin{array}{l}\text { Compra a terra } \\
\text { e compra as } \\
\text { mudas } \\
\text { (M1) }\end{array}$} & TIR & 0.094 & 0.014 & 0.086 & 0.690 & 0 \\
\hline & $\mathrm{VA}$ & 6028.532 & 2969.779 & 2469.000 & 0.915 & 0 \\
\hline & $\mathrm{RBC}$ & 2.269 & 0.718 & 1.790 & 0.700 & 0 \\
\hline & PBS & 25.000 & 0.000 & 25.000 & 0.000 & 0 \\
\hline & PBE & 25.000 & 0.000 & 25.000 & 0.000 & 1 \\
\hline & CTA & 5044.725 & 1042.994 & 3126.000 & 0.990 & 0 \\
\hline \multirow{6}{*}{$\begin{array}{l}\text { Arrenda a } \\
\text { terra e compra } \\
\text { as mudas } \\
\text { (M2) }\end{array}$} & TIR & 0.089 & 0.019 & 0.086 & 0.565 & 0 \\
\hline & VA & 4172.446 & 2971.009 & 2469.000 & 0.690 & 0 \\
\hline & $\mathrm{RBC}$ & 1.697 & 0.551 & 1.790 & 0.380 & 0 \\
\hline & PBS & 25.000 & 0.000 & 25.000 & 0.000 & 0 \\
\hline & PBE & 25.000 & 0.000 & 25.000 & 1.000 & 12 \\
\hline & CTA & 6562.122 & 1238.824 & 3126.000 & 1.000 & 0 \\
\hline \multirow{6}{*}{$\begin{array}{l}\text { Sem o custo } \\
\text { da Terra e com } \\
\text { compra de } \\
\text { mudas (M3) }\end{array}$} & TIR & 0.152 & 0.013 & 0.086 & 1.000 & 0 \\
\hline & VA & 8954.576 & 2788.047 & 2469.000 & 1.000 & 0 \\
\hline & RBC & 7.132 & 1.973 & 1.790 & 1.000 & 0 \\
\hline & PBS & 25.000 & 0.000 & 25.000 & 0.000 & 0 \\
\hline & $\mathrm{PBE}$ & 25.000 & 0.000 & 25.000 & 0.000 & 0 \\
\hline & CTA & 1467.440 & 88.085 & 3126.000 & 0.000 & 0 \\
\hline
\end{tabular}

Fonte: valores calculados pelo autor pela simulação de Monte Carlo

Tabela 13 - Indicadores de rentabilidade considerando análise de risco para plantio de paumarfim, com doação de mudas pelo governo

\begin{tabular}{|c|c|c|c|c|c|c|}
\hline Especificação & Indicador & Média & Desvio-padrão & Limite(L) & $\mathrm{P}(\mathrm{I}>\mathrm{L})$ & N.S. \\
\hline \multirow{6}{*}{$\begin{array}{l}\text { Compra a } \\
\text { Terra e as } \\
\text { mudas são } \\
\text { doadas pelo } \\
\text { governo } \\
\text { (M4) } \\
\end{array}$} & TIR & 0.104 & 0.014 & 0.086 & 0.880 & 0 \\
\hline & $\mathrm{VA}$ & 7404.954 & 2876.706 & 2469.000 & 0.975 & 0 \\
\hline & $\mathrm{RBC}$ & 2.781 & 0.856 & 1.790 & 0.880 & 0 \\
\hline & PBS & 25.000 & 0.000 & 25.000 & 0.000 & 0 \\
\hline & PBE & 25.000 & 0.000 & 25.000 & 0.000 & 0 \\
\hline & CTA & 4450.225 & 1000.965 & 3126.000 & 0.910 & 0 \\
\hline \multirow{6}{*}{$\begin{array}{l}\text { Arrenda a } \\
\text { Terra e as } \\
\text { mudas são } \\
\text { doadas pelo } \\
\text { governo } \\
\text { (M5) }\end{array}$} & TIR & 0.098 & 0.020 & 0.086 & 0.720 & 0 \\
\hline & $\mathrm{VA}$ & 4712.577 & 2937.903 & 2469.000 & 0.755 & 0 \\
\hline & RBC & 1.884 & 0.616 & 1.790 & 0.500 & 0 \\
\hline & PBS & 25.000 & 0.000 & 25.000 & 0.000 & 0 \\
\hline & PBE & 25.000 & 0.000 & 25.000 & 0.000 & 6 \\
\hline & CTA & 5798.224 & 1243.906 & 3126.000 & 1.000 & 0 \\
\hline \multirow{6}{*}{$\begin{array}{l}\text { Sem o custo } \\
\text { da Terra e as } \\
\text { mudas são } \\
\text { doadas pelo } \\
\text { governo } \\
\text { (M6) } \\
\end{array}$} & TIR & 0.192 & 0.015 & 0.086 & 1.000 & 0 \\
\hline & $\mathrm{VA}$ & 9963.400 & 3135.624 & 2469.000 & 1.000 & 0 \\
\hline & RBC & 13.829 & 4.219 & 1.790 & 1.000 & 0 \\
\hline & PBS & 23.325 & 2.366 & 25.000 & 0.000 & 0 \\
\hline & PBE & 25.000 & 0.000 & 25.000 & 0.000 & 0 \\
\hline & CTA & 781.071 & 45.033 & 3126.000 & 0.000 & 0 \\
\hline
\end{tabular}

Fonte: valores calculados pelo autor pela simulação de Monte Carlo 
Tabela 14 - Indicadores de rentabilidade considerando análise de risco para plantio de pinheirobrasileiro, com aquisição de mudas

\begin{tabular}{|c|c|c|c|c|c|c|}
\hline Especificação & Indicador & Média & Desvio-padrão & Limite (L) & $\mathrm{P}(\mathrm{I}>\mathrm{L})$ & N.S. \\
\hline \multirow{6}{*}{$\begin{array}{l}\text { Compra a terra } \\
\text { e compra as } \\
\text { mudas } \\
\text { (P1) }\end{array}$} & TIR & 0.106 & 0.016 & 0.095 & 0.720 & 0 \\
\hline & VA & 8967.671 & 3734.460 & 3364.000 & 0.970 & 0 \\
\hline & RBC & 2.998 & 1.035 & 2.200 & 0.725 & 0 \\
\hline & PBS & 25.000 & 0.000 & 25.000 & 0.000 & 0 \\
\hline & $\mathrm{PBE}$ & 25.000 & 0.000 & 25.000 & 0.000 & 0 \\
\hline & CTA & 4829.331 & 1035.495 & 2812.000 & 0.990 & 0 \\
\hline \multirow{6}{*}{$\begin{array}{l}\text { Arrenda a } \\
\text { terra e compra } \\
\text { as mudas } \\
\text { (P2) }\end{array}$} & TIR & 0.102 & 0.021 & 0.095 & 0.630 & 0 \\
\hline & $\mathrm{VA}$ & 6339.049 & 3877.582 & 3364.000 & 0.780 & 0 \\
\hline & RBC & 2.111 & 0.780 & 2.200 & 0.370 & 0 \\
\hline & PBS & 25.000 & 0.000 & 25.000 & 0.000 & 0 \\
\hline & $\mathrm{PBE}$ & 25.000 & 0.000 & 25.000 & 0.000 & 5 \\
\hline & CTA & 6155.793 & 1201.233 & 2812.000 & 1.000 & 0 \\
\hline \multirow{6}{*}{$\begin{array}{l}\text { Sem o custo } \\
\text { da Terra e } \\
\text { compra as } \\
\text { mudas } \\
\text { (P3) }\end{array}$} & TIR & 0.170 & 0.013 & 0.095 & 1.000 & 0 \\
\hline & $\mathrm{VA}$ & 10796.835 & 3250.495 & 3364.000 & 1.000 & 0 \\
\hline & $\mathrm{RBC}$ & 10.259 & 2.791 & 2.200 & 1.000 & 0 \\
\hline & PBS & 25.000 & 0.000 & 25.000 & 0.000 & 0 \\
\hline & PBE & 25.000 & 0.000 & 25.000 & 0.000 & 0 \\
\hline & CTA & 1168.624 & 63.494 & 2812.000 & 0.000 & 0 \\
\hline
\end{tabular}

Fonte: valores calculados pelo autor pela simulação de Monte Carlo

Tabela 15 - Indicadores de rentabilidade considerando análise de risco para plantio de pinheirobrasileiro, com doação de mudas pelo governo

\begin{tabular}{|c|c|c|c|c|c|c|}
\hline Especificação & Indicador & Média & Desvio-padrão & Limite(L) & $\mathrm{P}(\mathrm{I}>\mathrm{L})$ & N.S. \\
\hline \multirow{6}{*}{$\begin{array}{l}\text { Compra a } \\
\text { Terra e as } \\
\text { mudas são } \\
\text { doadas pelo } \\
\text { governo } \\
\text { (P4) } \\
\end{array}$} & TIR & 0.111 & 0.016 & 0.095 & 0.820 & 0 \\
\hline & VA & 9414.727 & 3957.875 & 3364.000 & 0.965 & 0 \\
\hline & $\mathrm{RBC}$ & 3.295 & 1.191 & 2.200 & 0.825 & 0 \\
\hline & PBS & 25.000 & 0.000 & 25.000 & 0.000 & 0 \\
\hline & PBE & 25.000 & 0.000 & 25.000 & 0.000 & 0 \\
\hline & $\mathrm{CTA}$ & 4411.574 & 999.838 & 2812.000 & 0.975 & 0 \\
\hline \multirow{6}{*}{$\begin{array}{l}\text { Arrenda a } \\
\text { Terra e as } \\
\text { mudas são } \\
\text { doadas pelo } \\
\text { governo } \\
\text { (P5) } \\
\end{array}$} & TIR & 0.108 & 0.020 & 0.095 & 0.725 & 0 \\
\hline & VA & 6868.828 & 3720.662 & 3364.000 & 0.840 & 0 \\
\hline & $\mathrm{RBC}$ & 2.237 & 0.737 & 2.200 & 0.460 & 0 \\
\hline & PBS & 25.000 & 0.000 & 25.000 & 0.000 & 0 \\
\hline & PBE & 25.000 & 0.000 & 25.000 & 0.000 & 3 \\
\hline & CTA & 5911.966 & 1193.094 & 2812.000 & 1.000 & 0 \\
\hline \multirow{6}{*}{$\begin{array}{l}\text { Sem o custo } \\
\text { da Terra e as } \\
\text { mudas são } \\
\text { doadas pelo } \\
\text { governo } \\
\text { (P6) }\end{array}$} & TIR & 0.197 & 0.015 & 0.095 & 1.000 & 0 \\
\hline & $\mathrm{VA}$ & 11562.708 & 3669.919 & 3364.000 & 1.000 & 0 \\
\hline & RBC & 15.889 & 4.699 & 2.200 & 1.000 & 0 \\
\hline & PBS & 24.840 & 0.786 & 25.000 & 0.000 & 0 \\
\hline & $\mathrm{PBE}$ & 25.000 & 0.000 & 25.000 & 0.000 & 0 \\
\hline & CTA & 778.260 & 43.958 & 2812.000 & 0.000 & 0 \\
\hline
\end{tabular}

Fonte: valores calculados pelo autor pela simulação de Monte Carlo 
De maneira geral, os indicadores de rentabilidade, tanto na análise determinista quanto na de risco, foram favoráveis à implantação de quase todos os projetos considerados. Uma das desvantagens destes reflorestamentos com essências nativas para muitos investidores poderia ser o fluxo de caixa negativo por muitos anos. Deve-se ressaltar que as estimativas foram para áreas de 1 hectare, ou seja, poderiam ser feitos plantios em áreas maiores e parcelados para se melhorar o fluxo de caixa. Outro aspecto que poderia desincentivar muitos investidores é o grande periodo de recuperação do capital. Neste caso, poderia se pensar em maiores incentivos do poder público na implantação dos projetos (doação de outros insumos além das mudas) já que existem beneficios sociais . Além disso, poderia se pensar nesses projetos como parte integrante de um projeto maior que abrangeria outra atividade com periodo de retorno do capital menor, como por exemplo um sistema de agrosilvicultura ou silvipastoril. 


\section{CONCLUSÕES}

Este trabalho analisou a viabilidade econômica dos reflorestamentos com essências nativas brasileiras visando à produção de toras a serem utilizadas na indústria de desdobro mecânico das mesmas. Para tanto, tomou-se como caso em estudo o Estado de São Paulo.

Atualmente, a oferta de madeiras de espécies nativas do Brasil está baseada na exploração predatória da Floresta Amazônica. Esta, apesar de enorme, está diminuindo a cada ano, repetindo o mesmo processo observado na Mata Atlântica e nos pinheirais da região Sul do Brasil. Por outro lado, a demanda por madeiras de espécies nativas brasileiras advém principalmente do mercado interno ( $86 \%$ do total produzido). Dentre os Estados brasileiros, São Paulo é o principal consumidor ( $20 \%$ do total produzido). No entanto, apenas algumas espécies de alto valor econômico são comercializadas neste mercado devido aos altos custos dos fretes. Com isso, há um desequilibrio entre oferta e demanda de madeiras nativas no Estado de São Paulo.

Além da questão da distância entre regiões produtoras e consumidoras, a preocupação com o meio ambiente por parte dos consumidores tem crescido e, parte destes, tem dado preferência pelos produtos "ambientalmente corretos". Com isso, a certificação florestal tem sido um instrumento de mercado utilizado para se diferenciar produtos florestais oriundos de áreas manejadas de forma sustentada daqueles oriundos de áreas manejadas de forma predatória. Alguns estudos mostram que se por um lado os custos de produção de produtos "ambientalmente corretos" são maiores, por outro, parte dos consumidores estariam dispostos a pagar preços maiores. De qualquer modo, há uma tendência para o aumento da participação destes produtos no mercado de nativas. E o reflorestamento com essências nativas pode atender a esse nicho de mercado.

Mas, não tem sido apenas o mercado o responsável por mudanças na dinâmica da oferta e demanda de madeiras nativas. O poder público também tem criado instrumentos que podem interferir nesta. A legislação florestal brasileira contém leis que limitam, parcial ou totalmente, a exploração de madeira de espécies nativas em determinadas áreas (áreas de 
preservação permanente, reserva florestal legal, reservas e estações ecológicas, entre outras). Além disso, através da reposição florestal obrigatória, o governo criou um mecanismo para a formação de áreas reflorestadas com recursos dos consumidores de matéria-prima florestal. Infelizmente, alguns avanços na legislação (como a obrigatoriedade da recomposição da reserva legal) ainda sofrem retrocesso, por pressões de produtores.

Do exposto acima, constatou-se que há uma demanda institucional pelo estabelecimento de reflorestamentos com essências nativas para fins de produção de madeira. Soma-se a isto, a demanda estratégica das empresas que poderão, no futuro, ficar sem a oferta oriunda do extrativismo (pelo esgotamento das reservas) ou que desejam atender a mercados diferenciados (produtos certificados). Por outro lado, o estabelecimento desses reflorestamentos depende da consolidação do conhecimento técnico e científico. Neste sentido, a pesquisa com estas espécies florestais tem se ampliado, o que pôde ser ratificado pela expansão do número de trabalhos publicados.

Dentre as áreas de pesquisa analisadas, a produção de mudas é condição necessária para o sucesso dos reflorestamentos. As pesquisas em que se comparava o desempenho entre espécies logo foram substituidas pelo melhoramento destas e, recentemente, surgiu a necessidade da conservação destes materiais genéticos, para não perdê-los. A área de manejo levantou vários aspectos que precisam de maior investigação, dentre estes está a definição da melhor forma de reflorestamentos através de plantios puros ou mistos em face às características sucessionais das espécies. As áreas de mecanização, controle de pragas e doenças, adubação e gerencial ainda se encontram numa fase muito preliminar. Porém, a pesquisa com espécies nativas pode se beneficiar em várias áreas do desenvolvimento das pesquisas com Pinus e Eucalipto.

Mesmo diante da necessidade de um maior desenvolvimento de várias áreas de pesquisa sobre essências nativas, algumas recomendações para o plantio comercial já foram feitas por alguns pesquisadores. Foi o caso da recomendação do plantio homogêneo das espécies pau-marfim, pinheiro-brasileiro e araruva em experimentos desenvolvidos no Estado de São Paulo, com longo período de observação. Apesar da recomendação dos 
pesquisadores, os critérios para a definição de viabilidade econômica destes reflorestamentos não eram suficientes. Assim, foi feita uma análise de projetos com outros indicadores mais apropriados, dentre os quais: o valor atual dos fluxos líquidos do projeto (VA), relação beneficio-custo (RBC), taxa interna de retorno (TIR), custo total atualizado (CTA), payback simples (PBS), payback econômico (PBE) e valor esperado da terra (VET).

Em condições estritamente deterministas dos projetos, o VA foi considerado (segundo a literatura) o indicador mais consistente. No entanto, concluiu-se que a sensibilidade deste em relação a taxa de juros pode modificar os resultados da análise. Por exemplo, entre $6 \%$ e $8 \%$, todos os projetos são considerados viáveis economicamente; entre $9 \%$ e $14 \%$, existem projetos viáveis e não viáveis; e, com $15 \%$ ou mais, todos os projetos são rejeitados. A mudança na taxa de juros também afeta a ordenação dos projetos. O que não é afetado pela taxa de juros é a relação de preferência de um projeto com doação de mudas pelo governo em relação ao mesmo projeto mas com a aquisição de mudas. A doação de mudas pelo governo fez com os projetos fossem rejeitados somente quando as taxas de juros eram de 1 a 3 pontos percentuais maiores em relação a taxa de juros que tornava inviável economicamente os projetos com compra de mudas.

Comparando-se o método do VA com os métodos da RBC, TIR e PBE, todos rejeitaram, na análise determinista, os mesmos projetos para cada um dos custos de oportunidade do capital. Mas, a ordenação de preferência entre os projetos não foi a mesma entre os métodos.

No caso dos projetos analisados pelo método do VET, todos foram rejeitados para juros iguais ou maiores que $12 \%$, inclusive o projeto com eucalipto (E1). A comparação entre o projeto $\mathrm{E} 1$ e os demais projetos com essências nativas mostrou que os projetos com essas são mais sensíveis ao aumento na taxa de juros, com exceção do projeto A6.

Pela análise determinista, pode-se observar que os projetos de reflorestamento com essências nativas foram considerados viáveis economicamente, principalmente para taxas de juros inferiores a $9 \%$.

A análise de risco foi realizada em duas etapas: a análise de sensibilidade e a 
simulação de Monte Carlo. Da construção de novos cenários visando observar a sensibilidade dos indicadores a variações de algumas variáveis, depreende-se uma importante conclusão: apesar dos três projetos (plantio de araruva, pau-marfim e pinheiro-brasileiro) terem sido considerados viáveis economicamente, tanto do ponto de vista do VA quanto da TIR, para uma taxa de juros de $6 \%$ ao ano, o investidor deve ficar alerta quanto a origem do material genético a ser utilizado no reflorestamento com essências nativas. Com isso, ratifica-se, pela análise econômica, a importância dos investimentos em pesquisa, em particular para os programas de melhoramento genético. Sem esses, esforços feitos para a valorização de madeiras certificadas, doação de mudas etc, podem ser neutralizados e, com isso, diminuindo a atratividade do reflorestamento com essências nativas.

Da simulação de Monte Carlo conclui-se que os projetos de reflorestamento com essências nativas são, na sua maioria, mais atrativos, considerando-se a condição de risco, do que os respectivos nas condições deterministas. Ainda, comparando esses, principalmente o plantio da araruva, com outros projetos agropecuários, conclui-se que este tipo de reflorestamento é bastante competitivo.

Em ambos os casos, análise determinista ou sob condição de risco, a doação de mudas pelo governo teve papel importante na melhoria das estimativas dos indicadores. Conclui-se que o poder público deveria avaliar a possibilidade de incentivo do governo através da doação de insumos já que os beneficios indiretos das florestas são para toda a sociedade.

Por fim, deve-se ressaltar que os projetos foram baseados em experimentos. Assim, reflorestamentos comerciais de maior escala necessitarão da continuidade das pesquisas. Além disto, necessita-se analisar outras alternativas (como o plantio parcelado ou a adoção de sistemas agro-silvi-pastoris) que permitam obter um fluxo de caixa líquido menos negativo e recuperar mais rapidamente o capital. 


\section{REFERÊNCIAS BIBLIOGRÁFICAS}

ANTON ANGELO, A. As inovações tecnológicas na silvicultura brasileira e seus impactos sobre a expansão desta atividade. Piracicaba, 1996. 173p. Dissertação (M.S.) - Escola Superior de Agricultura "Luiz de Queiroz", Universidade de São Paulo.

AZEVEDO FILHO, A.J.B.V. DETERPRJ - Sistema para análise econômica de projetos em condições deterministas: manual do usuário. Piracicaba: USP/PCP/CIAGRI - Centro de Informática na Agricultura, 1988. 89p.

AZEVEDO FILHO, A.J.B.V. Análise econômica de projetos: "software" para situações deterministas e de risco envolvendo simulação. Piracicaba, 1988. 127p. Dissertação (M.S.) - Escola Superior de Agricultura “Luiz de Queiroz”, Universidade de São Paulo.

AZEVEDO FILHO, A.J.B.V. Elementos de matemática financeira e análise de projetos de investimento. Piracicaba: DESR/ESALQ, 1995. 92p. (Série Didática, 109)

BACHA, C.J.C. As Políticas Florestais Estaduais: os casos de Minas Gerais, Rio de Janeiro, São Paulo e Paraná. Piracicaba: DESR/ESALQ/USP, abril 1998. (Relatório de Pesquisa).

BACHA, C.J.C.; CASAGRANDI, D.A. Desvalorização cambial e mudança na legislação florestal beneficiam setor produtivo. Preços Agrícolas, v. 14, n.148, p.34-35, fev.1999.

BARBOSA, P.A. O Brasil e o desafio das políticas de selo verde. Silvicultura, v.15, n.6, p.2-4, 1995. 
BRASIL. Leis, decretos, etc. Lei $\mathrm{n}^{\circ} 4.771$ de 15 de setembro de 1965 . Institui o Novo Código Florestal. In: VENTURA, V.J.; RAMBELLI, A.M. Legislação Federal sobre o Meio Ambiente. 2. ed. Taubaté: VANA, 1996. p.38-47.

BRASIL. Leis, decretos, etc. Lei nº 6.902 de 27 de abril de 1981. Dispõe sobre a criação de Estações Ecológicas, Áreas de Proteção Ambiental. In: VENTURA, V.J.; RAMBELLI, A.M. Legislação Federal sobre o Meio Ambiente. 2. ed. Taubaté: VANA, 1996. p.91-92.

BRASIL. Leis, decretos, etc. Lei $\mathrm{n}^{\circ} 6.938$ de 31 de agosto de 1981. Dispõe sobre a Política Nacional do Meio Ambiente, seus fins e mecanismos de formulação e aplicação. In: VENTURA, V.J.; RAMBELLI, A.M. Legislação Federal sobre o Meio Ambiente. 2. ed. Taubaté: VANA, 1996. p.93-102.

BRASIL. Leis, decretos, etc. Decreto $\mathrm{n}^{\mathrm{Q}} 89.336$ de 31 de janeiro de 1984 . Dispõe sobre as Reservas Ecológicas e Áreas de Relevante Interesse Ecológico, e da outras providências. In: VENTURA, V.J.; RAMBELLI, A.M. Legislação Federal sobre o Meio Ambiente. 2. ed. Taubaté: VANA, 1996. p.314-315.

BRASIL. Leis, decretos, etc. Resolução CONAMA nº 001 de 23 de janeiro de 1986. Dispõe sobre as diretrizes gerais para uso e implantação da Avaliação de Impacto Ambiental. In: VENTURA, V.J.; RAMBELLI, A.M. Legislação Federal sobre o Meio Ambiente. 2. ed. Taubaté: VANA, 1996. p.821-824.

BRASIL. Leis, decretos, etc. Lei $\mathrm{n}^{\circ} 7.754$ de 14 de abril de 1989. Estabelece medidas para proteção das florestas existentes nas nascentes dos rios. In: VENTURA, V.J.; RAMBELLI, A.M. Legislação Federal sobre o Meio Ambiente. 2. ed. Taubaté: VANA, 1996. p.116. 
BRASIL. Leis, decretos, etc. Decreto $n^{\circ} 98.897$ de 30 de janeiro de 1990. Dispõe sobre as reservas, extrativistas. In: VENTURA, V.J.; RAMBELLI, A.M. Legislação Federal sobre o Meio Ambiente. 2. ed. Taubaté: VANA, 1996. p.379-382.

BRASIL. Leis, decretos, etc. Lei $\mathrm{n}^{\circ} 8.171$ de de janeiro de 1991. Dispõe sobre a Política Agrícola. In: VENTURA, V.J.; RAMBELLI, A.M. Legislação Federal sobre o MeioAmbiente. 2. ed. Taubaté: VANA, 1996. p.130-135.

BRASIL. Leis, decretos, etc. Decreto $n^{\circ} 750$ de 10 de fevereiro de 1993. Dispõe sobre o corte, a exploração e a supressão de vegetação primária ou nos estágios avançado e médio de regeneração da Mata Atlântica, e dá outras providências. In: VENTURA, V.J.; RAMBELLI, A.M. Legislação Federal sobre o Meio Ambiente. 2. ed. Taubaté: VANA, 1996. p.402-403.

BRASIL. Leis, decretos, etc. Decreto $n^{0} 1.282$, de 19 de outubro de 1994. Regulamenta os artigos 15, 19, 20 e 21, da Lei n 4.771, de 15 de setembro de 1965, e dá outras providências. In: VIEIRA, J.L. (Ed.) Código Florestal: Lei $n^{\circ} 4.771$, de 15-9-65, Código de proteção à fauna: Lei n ${ }^{\circ} 5.197$, de 31-1-67, Código de pesca: Decreto-Lei 221, de 28-2-67 e Legislação Complementar. 3. ed. São Paulo: EDIPRO, 1996. p.30-37.

BRASIL. Leis, decretos, etc. Decreto $\mathrm{n}^{\circ} 1.298$, de 27 de outubro de 1994. Aprova o Regulamento das Florestas Nacionais, e dá outras providências. In: VENTURA, V.J; RAMBELLI, A.M. Legislação Federal sobre o Meio Ambiente. 2. ed. Taubaté: VANA, 1996. p.449-450.

BUSSEY, L.E. The economic analysis of industrial projects. Englendwood Cliffs: Prentice-Hall, 1978. 491p. 
CAMPINHOS JR., E.; IKEMORI, Y.K. Introdução de nova técnica na produção de mudas de essências florestais. Silvicultura, v.8, n.28, p.226, jan./fev.1983. /Apresentado ao 4 Congresso Florestal Brasileiro, Belo Horizonte, 1982 - Anais/

CARVALHO, P.E.R. Resultados experimentais de espécies madeireiras nativas do Estado do Paraná. Silvicultura em São Paulo, v.16A, parte 2, p.747-765, 1982. Edição Especial. /Apresentado ao Congresso Nacional sobre Essências Nativas, Campos do Jordão, 1982 - Anais/

CARVALHO, J.C. O esforço do IBDF em prol das exportações da Floresta Amazônica o papel das florestas nacionais. In: ENCONTRO BRASILEIRO DE ECONOMIA FLORESTAL, 1., Curitiba, 1988. Anais. Curitiba: EMBRAPA/CNPF, 1988. p.15-41.

CARVALHO, P.E.R. Espécies florestais brasileiras: recomendações silviculturais, potencialidades e uso da madeira. Colombo: EMBRAPA-CNPF; Brasília: EMBRAPA - SPI, 1994. 639p.

COELHO, L.C.C.; NOGUEIRA, J.C.B.; SIQUEIRA, A.C.M.F.; BUZATTO, O; SALLES, L.M.A.B. Ensaio de espaçamento de ibirá-puitá - Peltophorum dubium (Spreng) Taub., frente às condições de Mogi Guaçu - S.P. Silvicultura em São Paulo, v.16A, parte 2, p.1036-1038, 1982. Edição Especial. /Apresentado ao Congresso Nacional sobre Essências Nativas, Campos do Jordão, 1982 - Anais/

CONGRESSO FLORESTAL BRASILEIRO, 1., Curitiba, 1953. Anais. Curitiba: Instituto Nacional do Pinho, 1953. 507p.

CONTADOR, C.R. Avaliação social de projetos. São Paulo: Atlas, 1981. 301p. 
CLUTTER, J.L. et al. Timber Management : a quatitative approach. New York: John Wiley, 1983. 333p.

FARO, C. Engenharia Econômica: elementos. São Paulo: APEC, 1972. 338p.

GALVÃO, A.P.M. Contribuição da EMBRAPA/IBDF-PNPF para a pesquisa com espécies nativas e florestais naturais no Brasil. Silvicultura em São Paulo, v.16A, parte 1, p.150159, 1982. Edição Especial. /Apresentado ao Congresso Nacional sobre Essências Nativas, Campos do Jordão, 1982 - Anais/

GARRIDO, M.A.O. Características silviculturais de algumas espécies indígenas sob povoamentos puros e mistos. Silvicultura em São Paulo, v.9, p.63-71, 1975.

GARRIDO, M.A.O. et al. Programa de pesquisa e experimentação com essências indigenas no âmbito do Instituro Florestal de São Paulo. Silvicultura, v.2, n.14, p.232-235, 1978. Edição Especial. /Apresentado ao 3.Congresso Florestal Brasileiro, Manaus, 1978 Anais/

GARRIDO, M.A.O. Caracteres silviculturais e conteúdo de nutrientes no folhedo de alguns povoamentos puros e misto de espécies nativas. Piracicaba, 1981. 105p. Dissertação (M.S.) - Escola Superior de Agricultura "Luiz de Queiroz", Universidade de São Paulo.

GARRIDO, M.A.O; NOGUEIRA, J.C.B;; GARRIDO, L.M.A.G. Características silviculturais do pau-marfim - Balfourodendron riedelianum Engl. Silvicultura em São Paulo, v.16A, parte 2, p.1081-1085, 1982. Edição Especial. /Apresentado ao Congresso Nacional sobre Essências Nativas, Campos do Jordão, 1982 - Anais/ 
GARRIDO, M.A.O; SOUZA, A.C. Manejo científico de povoamentos florestais de espécies indigenas. Silvicultura, n.28, p.60-63, 1983. /Apresentado ao 4. Congresso Florestal Brasileiro, Belo Horizonte, 1982 - Anais/

GARRIDO, M.A.O; DOMINGOS, P.R.; GARRIDO, L.M.A.G; DURIGAN, G. Pesquisa e experimentação com cinco espécies nativas. In: CONGRESSO FLORESTAL BRASILEIRO, 6., Campos do Jordão, 1990. Anais. Campos do Jordão: SBS/SBEF, 1990. p.602-610

GURGEL FILHO, O.A. O Reflorestamento. São Paulo: Secretaria da Agricultura. Serviço Florestal, p.25, 1962. (Boletim, 6)

GURGEL FILHO, O.A.; GARRIDO, L.M.A.G.; NETTO, S.M.R. Características silviculturais e biométricas do crescimento de algumas essências da zona temperada. Silvicultura, n.14, v.2, p.60-81, 1978. Edição Especial. /Apresentado ao 3. Congresso Florestal Brasileiro, Manaus, 1978 - Anais/

GURGEL FILHO, O.A.; MORAES, J.L.; GARRIDO, L.M.A.G. Silvicultura de essências indígenas sob povoamentos homóclitos coetâneos experimentais: I - araribá amarelo (Centrolobium tomentosum Benth.). Silvicultura em São Paulo, v.16A, parte 2, p.841846, 1982a. Edição Especial. /Apresentado ao Congresso Nacional sobre Essências Nativas, Campos do Jordão, 1982 - Anais/

GURGEL FILHO, O.A.; MORAES, J.L.; GARRIDO, L.M.A.G. Silvicultura de essências indigenas sob povoamentos homóclitos coetâneos experimentais: II - guarantã (Esenbeckia leiocarpa Eng.). Silvicultura em São Paulo, v.16A, parte 2, p.847-851, 1982b. Edição Especial. /Apresentado ao Congresso Nacional sobre Essências Nativas, Campos do Jordão, 1982 - Anais/ 
GURGEL FILHO, O.A.; MORAES, J.L.; GARRIDO, L.M.A.G. Silvicultura de essências indígenas sob povoamentos homóclitos coetâneos experimentais: III - ibirá (Peltophorum vogelianum Benth.). Silvicultura em São Paulo, v.16A, parte 2, p.852-856, 1982c. Edição Especial. /Apresentado ao Congresso Nacional sobre Essências Nativas, Campos do Jordão, 1982 - Anais/

GURGEL FILHO, O.A.; MORAES, J.L.; GARRIDO, L.M.A.G. Silvicultura de essências indígenas sob povoamentos homóclitos coetâneos experimentais: IV - jatobá (Hymenaea stilbocarpa Hayne). Silvicultura em São Paulo, v.16A, parte 2, p.857-861, 1982. Edição Especial. /Apresentado ao Congresso Nacional sobre Essências Nativas, Campos do Jordão, 1982d - Anais/

GURGEL FILHO, O.A.; MORAES, J.L.; GARRIDO, L.M.A.G. Silvicultura de essências indígenas sob povoamentos homóclitos coetâneos experimentais: V - pau-ferro (Caesalpina leiostachya (Benth.) Ducke). Silvicultura em São Paulo, v.16A, parte 2, p.862-866, 1982e. Edição Especial. /Apresentado ao Congresso Nacional sobre Essências Nativas, Campos do Jordão, 1982 - Anais/

GURGEL FILHO, O.A.; MORAES, J.L.; GARRIDO, L.M.A.G. Silvicultura de essências indigenas sob povoamentos homóclitos coetâneos experimentais: VI - pau-marfim (Balfourodendron riedelianum Eng.). Silvicultura em São Paulo, v.16A, parte 2, p.867871, 1982f. Edição Especial. /Apresentado ao Congresso Nacional sobre Essências Nativas, Campos do Jordão, 1982 - Anais/ 
GURGEL FILHO, O.A.; MORAES, J.L.; GARRIDO, L.M.A.G. Silvicultura de essências indigenas sob povoamentos homóclitos coetâneos experimentais: VII- pau-pereira (Platycyamus regnellii Eng.). Silvicultura em São Paulo, v. 16A, parte 2, p.872-877, 1982g. Edição Especial. /Apresentado ao Congresso Nacional sobre Essências Nativas, Campos do Jordão, 1982 - Anais/

GURGEL FILHO, O.A; MORAES, J.L.; GARRIDO, L.M.A.G. Silvicultura de essências indígenas sob povoamentos homóclitos coetâneos experimentais: VIII- peroba-rosa (Aspidosperma polyneuron M.Arg. ). Silvicultura em São Paulo, v.16A, parte 2, p.878883, 1982h. Edição Especial. /Apresentado ao Congresso Nacional sobre Essências Nativas, Campos do Jordão, 1982 - Anais/

GURGEL FILHO, O.A.; MORAES, J.L.; GARRIDO, L.M.A.G. Silvicultura de essências indígenas sob povoamentos homóclitos coetâneos experimentais: IX - pinheiro-brasileiro (Araucaria angustifolia O.Ktze.). Silvicultura em São Paulo, v.16A, parte 2, p.884-889, 1982i. Edição Especial. /Apresentado ao Congresso Nacional sobre Essências Nativas, Campos do Jordão, 1982 - Anais/

GURGEL FILHO, O.A; MORAES, J.L.; GARRIDO, L.M.A.G. Espécies nativas euxilóforas. Silvicultura em São Paulo, v.16A, parte 2, p.890-894, 1982j. Edição Especial. /Apresentado ao Congresso Nacional sobre Essências Nativas, Campos do Jordão, 1982 - Anais/

GURGEL FILHO, O.A.; MORAES, J.L; MORAIS, E. Caracteres silviculturais e competição entre espécies folhosas. Silvicultura em São Paulo, v.16A, parte 2, p.895900, 1982k. Edição Especial. /Apresentado ao Congresso Nacional sobre Essências Nativas, Campos do Jordão, 1982 - Anais/ 
HOSOKAWA, R.T. Funções e tarefas das florestas. In: SIMPÓSIO SOBRE SILVICULTURA Y MEJORAMENTO GENÉTICO DE ESPÉCIES FLORESTAIS, Buenos Aires, 1987. Anais. Buenos Aires: 1987. p. 112-122.

KAGEYAMA, P.Y.; DIAS, I.S. Aplicação da Genética em Espécies Florestais Nativas. Silvicultura em São Paulo, v.16A, parte 2, p.782-791, 1982. Edição Especial. /Apresentado ao Congresso Nacional sobre Essências Nativas, Campos do Jordão, 1982 - Anais/

LEITE, N.B. Beneficios diretos e indiretos da atividade florestal. Jornal dos Reflorestadores, v.1, n.2, p.12-13, 1979

LORENZI, H. Árvores brasileiras: manual de identificação e cultivo de plantas arbóreas do Brasil. Nova Odessa: Editora Plantarum, 1992. 220p.

MELLO, H.A. Elementos de dendrologia. Piracicaba: Escola Superior de Agricultura "Luiz de Queiroz". Departamento de Silvicultura, 1973. 13p.

MERCADO,R.S.; CAMPAGNANI, S. Exportações da Floresta Amazônica. In: ENCONTRO BRASILEIRO DE ECONOMIA FLORESTAL, 1., Curitiba, 1988. Anais. Curitiba: EMBRAPA/CNPF, 1988. p.43-73.

MONCADA, R.G. Certificación de maderas tropicales: una respuesta a las distorsiones en el mercado. Revista Forestal Centroamericana, v.4, n.12, p.11-15, dez.1995.

MYERS, N. The word's forest and human populations: the environmental interconnections. In: DAVIS, K.; BERNSTAM, M.S. (Ed.). Resources, environment and population - present knowledge, future options. A supplement to v.16, Population and development review. 1990. p.237-251. 
NOGUEIRA, J.C.B.;SIQUEIRA, A.C.M.F.; MORAIS, E. et al. Conservação genética de essências nativas através de ensaios de progênie e procedência. Silvicultura em São Paulo, v.16A, parte 2, p.957-969, 1982a. Edição Especial. /Apresentado ao Congresso Nacional sobre Essências Nativas, Campos do Jordão, 1982 - Anais/

NOGUEIRA, J.C.B.;SIQUEIRA, A.C.M.F.; BERTOLDI, S.L. Ensaio de espaçamento do araribá-amarelo - Centrolobium tomentosum Guill, frente às condições de Pederneiras SP. Silvicultura em São Paulo, v.16A, parte 2, p.1039-1042, 1982b. Edição Especial. /Apresentado ao Congresso Nacional sobre Essências Nativas, Campos do Jordão, 1982 - Anais/

NOGUEIRA, J.C.B.;SIQUEIRA, A.C.M.F; GARRIDO, M.A.O. et al. Ensaio de competição de algumas essências nativas em diferentes regiões do Estado de São Paulo. Silvicultura em São Paulo, v.16A, parte 2, p.1051-1063, 1982c. Edição Especial. /Apresentado ao Congresso Nacional sobre Essências Nativas, Campos do Jordão, 1982 - Anais/

NORONHA,J.F. Projetos agropecuários: administração financeira, orçamento e viabilidade econômica. 2.ed. São Paulo: Atlas, 1987. 269p.

PONCE, R.H. Perspectivas do eucalipto na substituição de madeiras nativas. In: SEMINÁRIO SOBRE PROCESSAMENTO E UTILIZAÇÃO DE MADEIRAS DE REFLORESTAMENTO, 3., Curitiba, 1994. Anais. Curitiba: Associação Brasileira dos Produtores de Madeira, 1994. p.41-46.

PRATES, F.B. O Aproveitamento da madeira dos povoamentos de pinus. Jornal dos Reflorestadores, v.1, n.2, p.12-14, 1979. 
REIS, M.S. Programa e Ação Política do Instituto Brasileiro de Desenvolvimento Florestal para Essências Nativas. Silvicultura em São Paulo, v.16A, parte 1, p.44-89, 1982. Edição Especial. /Apresentado ao Congresso Nacional sobre Esências Nativas, Campos do Jordão, 1982 - Anais/

REIS, M.S. Mesa Redonda Internacional: oportunidades e limitações para o desenvolvimento da indústria baseada em madeiras tropicais na América Latina. Brasília: IBDF/ITTO, 1989. 538p.

RODRIGUEZ, L.C.E.; BUENO, A.R.S.; RODRIGUES, F. Rotações de eucalipto mais longas: análise volumétrica e econômica. Scientia Forestalis, n.51, p.15-28, jun.1997.

RODRIGUEZ, L.C.E.; RODRIGUES, F. Plantios Florestais: rentabilidade e visão de longo prazo. Preços Agrícolas, v. 14, n.155, p.10-12, set. 1999.

ROSA, P.R.F.da; NOGUEIRA, J.C.B.; SIQUEIRA, A.C.M.F.; SALLES, L.M.A.B. Caracteres silviculturais do ipê-amarelo Tabebuia vellosoi Tol. Silvicultura em São Paulo, v.16A, parte 2, p.1070-1075, 1982. Edição Especial. /Apresentado ao Congresso Nacional sobre Essências Nativas, Campos do Jordão, 1982 - Anais/

SILVA, L.O. Recomposição de matas nativas empreendida pela Companhia Energética de São Paulo. Revista do Instituto Florestal, v.4 (único), parte 4, p.1054-1060, 1992. Edição Especial. /Apresentado ao $2^{\circ}$ Congresso Nacional sobre Essências Nativas, São Paulo, 1992 - Anais/

SIMÕES, J.W. Estágio Atual do Ensino e da Pesquisa sobre Essências Nativas no Brasil. Silvicultura em São Paulo, v.16A, parte 2, p.792-797, 1982. Edição Especial. /Apresentado ao Congresso Nacional sobre Essências Nativas, Campos do Jordão, 1982 - Anais/ 
SIQUEIRA, A.C.M.F.; NOGUEIRA, J.C.B. Essências brasileiras e sua conservação genética no Instituto Florestal de São Paulo. Revista do Instituto Florestal, v.4 (único), parte 4, p. 1187, 1992. Edição Especial. /Apresentado ao $2^{\circ}$ Congresso Nacional sobre Essências Nativas, São Paulo, 1992 - Anais/

SIQUEIRA,J.P. Balanço de Ofertas e Demanda. In: SEMINÁRIO SOBRE PROCESSAMENTO E UTILIZAÇÃO DE MADEIRAS DE REFLORESTAMENTO, 3., Curitiba, 1994. Anais. Curitiba: Associação Brasileira de Produtores de Madeira, 1994. p.71-76.

SMERALDI, R.; VERÍSSIMO, J.A.O. Acertando o alvo: consumo de madeira no mercado interno brasileiro e promoção da certificação florestal. São Paulo: Amigos da Terra Programa Amazônia; Piracicaba: IMAFLORA; Belém: IMAZON, 1999. 41 p.

SOUZA,W.J.M; NOGUEIRA,J.C.B.; SIQUEIRA,A.C.M.F. et al. Ensaio de espaçamento de canela-imbuia - Ocotea porosa (Ness.) L.Barroso, em Angatuba - SP. Silvicultura em São Paulo, v.16A, parte 2, p.1043-1046, 1982. Edição Especial. /Apresentado ao Congresso Nacional sobre Essências Nativas, Campos do Jordão, 1982 - Anais/

TAKITANE, I.C. Custo de produção a borracha e análise de rentabilidade em condições de risco no planalto paulista, SP e no triângulo mineiro, MG. Piracicaba, 1988. 119p. Dissertação (M.S.) - Escola Superior de Agricultura 'Luiz de Queiroz", Universidade de São Paulo.

TOMASELLI, I. Influênica de Aspectos Ambientais no Mercado Nacional de Produtos Florestais. In: SEMINÁRIO SOBRE PROCESSAMENTO E UTILIZAÇÃO DE MADEIRAS DE REFLORESTAMENTO, 3., Curitiba, 1994. Anais. Curitiba: Associação Brasileira de Produtores de Madeira, 1994. p.25-31. 
VIANNA, V.M. A certificação socioambiental e o futuro do setor florestal no Brasil. In: SIMPÓSIO IPEF, 6., São Pedro, 1996. Anais. Piracicaba: ESALQ. DCF, 1996. p.1-4.

YARED, J.A.G.; BRIENZA JUNIOR, S.; CARVALHO, J.O.P.de et al. Silvicultura como Atividade Econômica na Região Amazônica. In: ENCONTRO BRASILEIRO DE ECONOMIA FLORESTAL, 1., Curitiba, 1988. Anais. Curitiba: EMBRAPA/CNPF, 1988. p. $15-41$.

ZANATTO, A.C.S.; NOGUEIRA, J.C.B.; SIQUEIRA, A.C.M.F.; BERTOLDI, S.E. Ensaio de espaçamentos de jequitibá-vermelho - Cariniana legalis (Mart.) O.Ktze. frente às condições de Luiz Antônio - São Paulo. Silvicultura em São Paulo, v.16A, parte 2, p.1047-1050, 1982. Edição Especial. /Apresentado ao Congresso Nacional sobre Essências Nativas, Campos do Jordão, 1982 - Anais/ 
Apêndice 1 - Descrição das áreas com exploração proibida no Brasil 
As áreas com exploração proibida no Brasil são: áreas de preservação permanente; parques nacionais, estaduais e municipais; e, as reservas biológicas.

As áreas de preservação permanente estão definidas no $2^{0}$ Código Florestal ${ }^{1}$, instituído pela Lei $\mathrm{n}^{\mathrm{0}} 4.771$ de 15/09/65. Pelo Código atual, são consideradas áreas de preservação permanente (artigo $2^{\mathrm{o}}$ ), as florestas e demais formas de vegetação natural situadas ${ }^{2}$ : nas margens dos rios ou de qualquer curso d'água; ao redor de lagoas, lagos ou reservatórios d'água; nas nascentes; no topo de morros, montes, montanhas e serras; nas encostas ou parte destas, com declividade superior a $45^{\circ}$; nas restingas, como fixadoras de dunas ou estabilizadoras de mangues; nas bordas dos taboleiros ou chapadas; e, em altitude superior a 1.800 metros, nos campos naturais ou artificiais.

O Poder Público também pode considerar como de preservação permanente (artigo $3^{\circ}$ ) determinadas florestas e demais formas de vegetação natural quando estas se destinam a: atenuar a erosão das terras; fixar as dunas; formar faixas de proteção ao longo de rodovias e ferrovias; auxiliar a defesa do território nacional a critério das autoridades militares; proteger sítios de excepcional beleza ou de valor científico ou histórico; asilar exemplares da fauna ou flora ameaçados de extinção; manter o ambiente necessário à vida das populações silvícolas; e, assegurar condições de bem-estar público.

No caso das populações silvícolas, todas as florestas que integram o Patrimônio Indigena ficam sujeitas ao regime de preservação permanente. Tanto neste caso, como nos outros, só será admitida a supressão parcial ou total de florestas de preservação permanente quando houver a necessidade de execução de obras, planos, atividades ou projetos de interesse público ou de utilidade social.

Em 14/04/89, a Lei $n^{0} 7.754$ estabeleceu medidas para a proteção das florestas e demais formas de vegetação natural existentes nas nascentes dos rios. Nestes locais, deve ser constituída uma área em forma de paralelograma, onde o desmatamento é proibido. No caso de já ter havido a derrubada de árvores e o desmatamento na área composta pelo Paralelograma de Cobertura Florestal, torna-se obrigatório o reflorestamento imediato com espécies vegetais nativas da

${ }^{1}$ Segundo Bacha (1993), antes da edição do atual Código Florestal, estas áreas foram definidas como florestas protetoras no $1^{\circ}$ Código Florestal (Decreto $\mathrm{n}^{\circ} 23.793$ de $23 / 01 / 34$ ), com as mesmas funções.

${ }^{2}$ A redação deste artigo é dada pela Lei $n^{\circ} 7.803$ de 18/07/89. 
região. Além dessa obrigatoriedade, a inobservância do disposto na lei acarreta multa aos infratores.

Outra medida tomada pelo governo federal, a fim de preservar áreas nativas remanescentes, foi a incumbência dada ao Poder Público para criar Parques Nacionais, Estaduais e Municipais e Reservas Biológicas. No atual Código Florestal, artigo $5^{\underline{o}}$, fica explicita a proibição de qualquer forma de exploração nestas áreas ${ }^{3}$.

Segundo Bacha (1993), os parques nacionais e reservas biológicas ocupavam uma área aproximada de 2,4 milhões de hectares até 1978. No ano seguinte, foi lançado o Plano de Sistema de Unidades de Conservação pelo Instituto Brasileiro de Desenvolvimento Florestal (IBDF). Já na $1^{\text {ś }}$ etapa (1979 a 1981) foram propostas 13 áreas, destas foram criadas 11 novas áreas nas regiões Norte e Nordeste, totalizando $6.884,4$ mil de hectares.

A partir da década de oitenta, as preocupações ecológicas traduziram-se na criação de novos tipos de áreas a serem preservadas. Na lei $\mathrm{n}^{0} 6.902$, de 27/04/81 (regulamentada pelo decreto $\mathrm{n}^{0}$ 99.274/90), está prevista a criação de áreas representativas de ecossistemas brasileiros, denominadas Estações Ecológicas. Nestas, $90 \%$ da área deve ser destinada à preservação integral da biota. Logo em seguida, a Política Nacional do Meio Ambiente (Lei ${ }^{\circ}$ 6.938 de 31/08/81) considerou como um de seus instrumentos a criação de espaços territoriais especialmente protegidos, dentre os quais as Reservas Ecológicas e Áreas de Relevante Interesse Ecológico (ARIE). A regulamentação veio através do Decreto $n^{0} 89.336$, de $31 / 01 / 84$. Neste, são consideradas como Reservas Ecológicas as áreas de preservação permanente mencionadas no Código Florestal, bem como as que forem estabelecidas por ato do Poder Público, excetuando-se as estabelecidas como Estações Ecológicas. Já as Áreas de Relevante Interesse Ecológico são aquelas que possuam caracteristicas naturais extraordinárias ou abriguem exemplares raros da biota regional. Dá-se preferência às áreas inferiores a cinco mil hectares e com mínima ação antrópica, que deverão receber cuidados especiais de proteção por parte do Poder Público.

\footnotetext{
${ }^{3}$ A redação é dada pela Lei $n^{9} 7.875$ de 13/11/89.
} 
Apêndice 2 - Descrição das Áreas com Exploração Limitada no Brasil 
As áreas com exploração limitada no Brasil são subdivididas em: florestas em áreas íngremes; florestas situadas nas regiões Leste Meridional, Sul e Centro-oeste; reserva legal; florestas nacionais; reservas extrativistas; remanescentes de Mata Atlântica; e, florestas da Bacia Amazônica.

\section{- Florestas em Áreas Íngremes}

A derrubada de florestas situadas em áreas íngremes (de inclinação entre 25 e 45 graus) não é permitida. Somente é tolerada a utilização racional da área com a extração de toros que visem a rendimentos permanentes (artigo 10 do Código Florestal).

- Florestas Situadas nas Regiões Leste Meridional, Sul e Centro-Oeste, esta na parte sul No artigo 16, do Código Florestal, as florestas de domínio privado, localizadas nas regiões Leste Meridional, Sul e Centro-Oeste, esta na parte sul, só podem ser exploradas sob certas restrições. Se forem áreas já desbravadas e previamente delimitadas pela autoridade competente, é proibida a substituição da floresta nativa por pastagens ou culturas. Somente é permitida a extração de árvores para a produção de madeira. Se esta floresta nativa está localizada na região Sul e, nesta, ocorre o pinheiro-brasileiro (Araucaria angustifolia), então só é permitido a exploração racional. Deve ser assegurada a garantia de permanência dos maciços em boas condições de desenvolvimento e produção.

\section{- Reserva Legal}

O conceito de reserva legal vem desde o $1^{0}$ Código Florestal (Decreto $\mathrm{n}^{0}$ 23.793, de 23/01/34). Naquele, as propriedades cujas terras eram cobertas com matas nativas originais só poderiam ser desmatadas até o teto máximo de $75 \%$ de sua área. Contudo, era aberta uma exceção às pequenas propriedades próximas de florestas ou zona urbana, ou aquelas que substituíssem a vegetação florestal heterogênea pela homogênea. Portanto, a eficácia deste instrumento era bastante questionável.

Ao longo dos anos, o posicionamento público quanto à reserva legal foi se alterando. $\mathrm{O}$ atual Código Florestal procura ser mais rigido e especifico do que o anterior, dando um tratamento diferenciado à reserva legal de acordo com as regiões do país. Nas regiões Leste Meridional, Sul e Centro-Oeste, esta na parte sul, as florestas de domínio privado, não sujeitas ao regime de utilização limitada e ressalvadas as de preservação permanente, não podem 
ser exploradas de qualquer forma. A autoridade competente deve estabelecer um mínimo de $20 \%$ da área de cada propriedade com cobertura arbórea localizada (artigo 16). No caso da instalação de novas propriedades agrícolas, em áreas incultas, só serão toleradas as derrubadas de florestas nativas até o máximo de $50 \%$ da área da propriedade.

Para as propriedades rurais, com área entre 20 e 50 hectares, esta área mínima tem características diferentes das demais. A autoridade competente computa, além da cobertura florestal de qualquer natureza, os maciços de porte arbóreo, sejam frutíferos, ornamentais ou industriais. Isto gerou muita distorção na região Nordeste, porque foram aceitos plantios homogêneos, com coqueiros, como sendo reserva legal. No mesmo artigo 16 do Código Florestal, podem ser encontradas outras restrições específicas para estas regiões citadas.

A definição explícita de reserva legal surgiu na Lei $\mathrm{n}^{0} 7.803$, de 18/07/89. Esta acrescentou dois parágrafos ao artigo 16 do Código Florestal. No parágrafo $2^{\underline{a}}$, diz-se que em cada propriedade não é permitido o corte raso em pelo menos $20 \%$ da sua área. Subentende-se que estes $20 \%$ da área são os mesmos declarados na alínea "a" deste artigo, ou seja, com cobertura arbórea localizada. No parágrafo $3^{\circ}$, estende-se o conceito de reserva legal para as áreas de cerrado.

Na região Norte e na parte Norte da região Centro-Oeste, o artigo 44 do Código Florestal diz que pelo menos $50 \%$ da área de cada propriedade deve permanecer com a cobertura arbórea. O termo reserva legal também surgiu posteriormente, na Lei $\mathrm{n}^{0} 7.803$, de 18/07/89 (reserva legal é a área de no mínimo $50 \%$ de cada propriedade, onde não é permitido o corte raso). Mas, não demorou muito, a Medida Provisória $\mathrm{n}^{\circ}$ 1.511/96 surgiu para alterar a área mínima para a reserva legal na região Norte e na parte norte da região Centro-Oeste, passando de $50 \%$ para $80 \%$ da área de cada propriedade

Pelo artigo 15, do Código Florestal, ficava proibida a exploração empírica das florestas primitivas desta região até que fossem estabelecidos planos técnicos de condução e manejo por ato do Poder Público. A regulamentação ocorreu com o Decreto nº 1.282, de 19/10/94.

Apesar da porção destinada à reserva legal ser diferente para os grupos de regiões citados, fica explícita a proibição do corte raso em qualquer situação. Logo, a exploração de madeira nestas áreas fica restrita a cortes seletivos de galhos para o obtenção de lenha.

A legislação também trata dos casos em que a reserva legal não é cumprida. Mesmo com os vários avanços promovidos pelo atual Código Florestal e os acréscimos da Lei $\mathrm{n}^{0}{ }^{7.803 \text {, }}$ 
somente na década de 90, com o surgimento da Lei $\mathrm{n}^{0}$ 8.171, de 17/01/91 (Lei Agrícola), os proprietários rurais passaram ser obrigados a recompor a chamada reserva florestal legal.

A recomposição deveria ser mediante o plantio, em cada ano, de pelo menos um trinta avos da área total. Apesar de parecer implicito que esta é uma área de mata natural e deveria ser feito o plantio de espécies nativas, a ausência desta afirmativa abriu precedentes para outras formas de recomposição (poderia ser feito o plantio com espécies exóticas e a recomposição natural surgiria no sub-bosque). Neste sentido, poderia haver a exploração destas exóticas a corte raso, já que a legislação ainda é vaga.

Segundo Bacha e Casagrandi (1999), devido aos resultados pouco significativos das normas anteriores e às pressões de produtores rurais, pressionados a repor a reserva florestal legal pelas ações judiciais, o governo federal resolveu alterar a sistemática de reposição e composição da reserva legal. Para isso, foi instituida a Medida Provisória 1736-31, de 14/12/98, cujas principais mudanças são:

- a reserva florestal legal não precisa mais ser constituída dentro da área da propriedade rural. Se o proprietário desejar, pode ser criada uma reserva florestal legal em outro local;

- nas regiões Norte e no norte da região Centro-Oeste, as áreas constituídas por vegetação de cerrado passam a ser obrigadas a destinar, no mínimo, $20 \%$ da área total da propriedade rural para a reserva legal;

- a vigência do artigo 99 da Lei 8.171 , de 17/01/91, fica suspensa por 120 dias até que a questão seja devidamente regulamentada; e,

- as áreas ocupadas com matas ciliares e encostas com mais de $45^{\circ}$ de inclinação podem ser computadas no cálculo da reserva legal.

\section{- Florestas Nacionais (FLONAS)}

A criação de FLONAS com fins econômicos, técnicos ou sociais, por parte do Poder Público, é prevista no artigo $5^{\circ}$ do Código Florestal. Pelo Decreto $n^{\circ} 1.298$, de 27/10/94, estas são áreas de domínio público, providas de cobertura vegetal nativa ou plantada, estabelecidas para atender a vários objetivos. Conforme o plano de manejo, as FLONAS poderão ter parte da área preservada e parte com uso racional (exploração limitada).

\section{- Reservas Extrativistas}


A criação de Reservas Extrativistas foi autorizada pela Lei no 7.804 de 18/07/89, que deu uma nova redação ao inciso VI, artigo $9^{\circ}$, da Politica Nacional do Meio Ambiente. Pelo Decreto $\mathrm{n}^{\circ} 98.897$, de 30/01/90, as reservas extrativistas são áreas destinadas à exploração autosustentável e conservação dos recursos naturais renováveis. Assim, a exploração destas áreas deve obedecer a condições pré-determinadas.

\section{- Remanescentes da Mata Atlântica}

Uma das mais recentes limitações ao uso de áreas remanescentes é o caso da Mata Atlântica (Decreto $\mathrm{n}^{\circ} 750$, de 10/02/93). Nesta, a vegetação primária ou em estágio avançado e médio de regeneração não pode ser cortada, explorada ou suprimida, a não ser que vise a utilidade pública ou o interesse social, e mediante a autorização do órgão competente. Também foi aberta uma exceção para o caso da exploração seletiva de determinadas espécies nativas, desde que observados alguns requisitos.

\section{- Florestas da Bacia Amazônica}

A limitação da exploração das florestas primitivas e demais formas de vegetação natural, na bacia amazônica, foi regulamentada pelo Decreto $\mathrm{n}^{\mathrm{0}} 1.282$, de 19/10/94. Assim, a exploração só é permitida sob a forma de manejo florestal sustentável, ou seja, desde que a administração da floresta proporcione benefícios econômicos e sociais, respeitando-se os mecanismos de sustentação do ecossistema objeto do manejo.

Enfim, deve-se destacar que outras áreas podem ter a sua exploração limitada pelo IBAMA. Através da Resolução CONAMA nº 001 foi regulamentado o estudo de impacto ambiental (EIA) e seu respectivo Relatório de Impacto Ambiental (RIMA) para o licenciamento de atividades modificadoras do meio ambiente. No que diz respeito aos recursos florestais, o RIMA passou a ser obrigatório para: a exploração econômica de madeira ou lenha em áreas acima de 100 hectares e em áreas menores do que 100 hectares, mas que são de importância ambiental, e para qualquer atividade que utilize carvão vegetal em quantidade superior a dez toneladas por dia. 
Apêndice 3 - Relação de Trabalhos Científicos sobre Essências Nativas no Brasil 
Neste apêndice 3 são apresentadas as referências bibliográficas dos trabalhos cientificos sobre espécies nativas que foram publicados nas revistas FLORESTA (1969 a 1997), ÁRVORE (1977 a 1997), IPEF (1970 a 1995) e SCIENTIA FORESTALIS (1996 e 1997); nos Anais do I, II, III, IV, V, VI e VII Congressos Florestais Brasileiros, realizados nos anos de 1953, 1973, 1978, 1983, 1986, 1990 e 1993, respectivamente; e, nos Anais do Congresso Nacional sobre Essências Nativas (1982) e $2^{\circ}$ Congresso Nacional sobre Essências Nativas (1992).

Os trabalhos estão citados de acordo com a área de pesquisa e seus segmentos em ordem cronológica. Adverte-se mais uma vez que, o número de trabalhos em cada ano não é o mesmo número de trabalhos somados para todas as áreas de determinado ano. Isto porque, o mesmo trabalho pode fazer parte de mais de uma área e/ou segmento de pesquisa.

\section{1) Produção de Mudas}

\section{3: 2 trabalhos}

KOHUT, R. Algumas observações sobre as plantações de Araucaria angustifolia nos campos paranaenses. In: CONGRESSO FLORESTAL BRASILEIRO, 1..Curitiba, 1953. Anais. Curitiba: Instituto Nacional do Pinho, 1953. p.137-142.

VASCONCELLOS, P.W.C. Saguaragi - Colubrina rufa, Reiss. familia Rhamnaceae 1) Consorciação com Eucaliptus tereticornis, Eucaliptus rostrata. In: CONGRESSO FLORESTAL BRASLEIRO, 1.,Curitiba, 1953. Anais. Curitiba: Instituto Nacional do Pinho, 1953. p.195-199.

1969: 1 trabalho

BRANDÃO, A.E. O Sobreiro. FLORESTA, v.1, n.1, p.67-68, junho 1969.

1970: 3 trabalhos

BAENA, E.S. A Produção de Mudas na Fazenda Monte Alegre (Viveiro Lagoa). FLORESTA, v.2, n.3, p.3743, dezembro 1970.

JANKAUSKIS, J. Ensaio sobre a Influência da Imersão na Seleção e Germinação de Araucaria angustifolia. FLORESTA, v.2, n.3, p. 53-57, dezembro 1970.

MACEDO, J.H.P. Palmito - Uma Grande Fonte de Divisas. FLORESTA, v.2, n.3, p.19-20, dezembro 1970. 1971: 1 trabalho

MACEDO, J.H.P. Palmito - Uma Grande Fonte de Divisas (II). FLORESTA, v.3, n.1, p.29-34, maio 1971. 1972: 1 trabalho

CARNEIRO, J.G.A. Ensaios de Estratificação de Sementes de Euterpe edulis. FLORESTA, v.4, n.1, p.15-17, dezembro 1972.

\section{3: 5 trabalhos}

BUCH, C.; LIMA. J.H.M. Morotó no reflorestamento do norte e nordeste brasileiro. In: CONGRESSO FLORESTAL BRASILEIRO, 2.,Curitiba, 1973. Anais. Curitiba:1973. p.86-87. 
LEMOS, J.M. Reflorestamento com Virola surinamensis (Ucuúba da várzea) na Ilha do Marajó. In: CONGRESSO FLORESTAL BRASILEIRO, 2.,Curitiba, 1973. Anais. Curitiba: 1973. p.109-111.

PEREIRA, A.P.; PEDROSO, L.M. Influência da profundidade de semeadua em algumas essências florestais da Amazônia (I). In: CONGRESSO FLORESTAL BRASILEIRO, 2.,Curitiba, 1973. Anais. Curitiba: 1973. p.54-55.

PINHEIRO, J.G. Semeadura mecanizada de araucaria. In: CONGRESSO FLORESTAL BRASILEIRO, 2.,Curitiba, 1973. Anais. Curitiba: 1973. p.92-93.

SCHIMIDT, P.B. Sobre a profundidade ideal de semeadura do mogno (Aguano) Swietenia macrophylla King. In: CONGRESSO FLORESTAL BRASILEIRO, 2.,Curitiba, 1973. Anais. Curitiba: 1973. p.137-139.

1974: 1 trabalho

POGGIANI, F. Efeito de alguns nutrientes sobre o crescimento inicial de duas espécies arbóreas do cerrado. IPEF, v.8, p.3-18, outubro 1974.

1975: 1 trabalho

CARNEIRO, J.G.A. Métodos de quebra de dormência de sementes. FLORESTA, v.6, n.1, p. 24-30, junho 1975.

\section{7: 3 trabalhos}

FERREIRA, M.G.M.; CÂNDIDO, J.F.; CANO, M.A.O, CONDÉ, A.R. Efeito do Sombreamento na Produção de Mudas de Quatro Espécies Florestais Nativas. ÁRVORE, v.1, n.2, p.121-134, $2^{\circ}$ semestre 1977.

MALINOVSKI, J.R. Métodos de poda radicular em Araucaria angustifolia (Bert.) O.Ktze e seus efeitos sobre a qualidade de mudas em raiz nua. FLORESTA, v.8, n.1, p. 85-88, junho 1977.

SEITZ, R.A. Algumas características ecológicas e silviculturais do vassourão branco (Piptocarpha angustifolia Dusén). FLORESTA, v.8, n.1, p. 89-92, junho 1977.

1978: 4 trabalhos

ALENCAR, J.C.; MAGALHÃES, L.M. Poder Germinativo de Sementes de Espécies Florestais na Região de Manaus. Silvicultura, v.2, n.14, p.415-418, 1978. Edição Especial. Apresentado ao 3. CONGRESSO FLORESTAL BRASILEIRO, Manaus, 1978 - Anais.

FERREIRA, M.G.M.; CÂNDIDO, J.F.; CANO, M.A.O; CONDÉ, A.R. Efeito do Sombreamento na Produção de Mudas de Quatro Espécies Florestais Nativas. I - Germinação ÁRVORE, v.2, n.1, p.61-67, $1^{\circ}$ semestre 1978.

INOUE, M.T.; GALVÃO,F.; TORRES,D. A Produção Primária de Araucaria angustifolia (Bert.) O.Ktze. No Estágio de Muda em Dependência da Intensidade Luminosa. Silvicultura, v.2, n.14, p.34-40, 1978. Edição Especial. Apresentado ao 3. CONGRESSO FLORESTAL BRASILEIRO, Manaus, 1978 - Anais.

MARQUEZ, F.C.M.; CASTRO, C.E.F.; KAGEYAMA. P.Y. Efeito da Temperatura na Germinação de Sementes de Pau Rei (Sterculia stricta). Silvicultura, v.2, n.14, p.339-342, 1978. Edição Especial. Apresentado ao 3. CONGRESSO FLORESTAL BRASILEIRO, Manaus, 1978 - Anais.

1979: 2 trabalhos

FREITAS, S.C.de; CÂNDIDO, J.F.; CONDÉ, A.R.; HARA, T. Determinação de equilibrio higroscópico e viabilidade de sementes de ipê-amarelo (Tabebuia serratifolia (Vahl) Nichols) armazenadas em diferentes umidades relativas. ÁRVORE, v.3, n.2, p.135-144, jul./dez. 1979.

MATTEI, V.L.; STOEHR, G.W.D.; MALINOVSKI, J.R. Caracteristicas morfológicas e profundidade de semeadura de Araucaria angustifolia (Bert.) O.Ktze. FLORESTA, v.10, n.2, p.46-54, dezembro 1979. 
1980: 3 trabalhos

FERREIRA, C.A. et al. Estudo do uso de baixas dosagens de radiação gama no conservação do poder germinativo de sementes de Araucaria angustifolia (Bert.) O.Kuntze. IPEF, v.21, p.67-84, dezembro 1980.

FREITAS, J.R.de et al. Aplicação de matéria orgânica, vermiculita e inoculação de Rhizobium spp em sementeiras de Erytrina falcata. IPEF, v.20, p.101-116, junho 1980.

INOUE, M.T. Comportamento do crescimento de mudas de Araucaria angustifolia (Bert.)O.Ktze em dependência da intensidade luminosa. FLORESTA, v.11, n.1, p.7-11, junho 1980.

1981: 1 trabalho

CANDIDO, J.F. et al. Estudo da causa da dormência em sementes de guapuruvu (Schizolobium parahybum (Vell) Blake) e metódos para a sua quebra. ÁRVORE, v.5, n.2, p.224-232, jul./dez. 1981.

1982: 18 trabalhos

ALCALAY, N.; AMARAL, D.M.I. Quebra de dormência em sementes de timbaúva - Enterolobium contortisiquum (Vell) Morong. SILVICULTURA EM SÃO PAULO, v.16A, parte2, p.1149-1152, 1982. Edição Especial. Apresentado ao Congresso Nacional sobre Essências Nativas, Campos do Jordão, 1982 Anais.

ALVES, S.T. Estudos sobre o pau-de-balsa (AM) Ochroma pyramidale - (Cav.) Urb. Bombacaceae. SILVICULTURA EM SÃo PAULO, v.16A, parte2, p.981-987, 1982. Edição Especial. Apresentado ao Congresso Nacional sobre Essências Nativas, Campos do Jordão, 1982 - Anais.

BARBOSA, J.M. Germinação de sementes de sete essências nativas. SILVICULTURA EM SÃo PAULO, v.16A, parte1, p.322-328, 1982. Edição Especial. Apresentado ao Congresso Nacional sobre Essências Nativas, Campos do Jordão, 1982a - Anais.

CAMPOS, A.G.P. Determinação de um método para obtenção de sementes de calabura (Muntingia calobura L.). SILVICULTURA EM SÃO PAULO, v.16A, parte2, p.1111-1113, 1982. Edição Especial. Apresentado ao Congresso Nacional sobre Essências Nativas, Campos do Jordão, 1982 - Anais.

CANDIDO,J.F et al. Influência de trunos de rega no endurecimento de mudas de guapuruvú (Schizolobium parahyba (Vell) Blake). ÁRVORE. v.6, n.2, p.111-120, jul./dez. 1982.

CANDIDO,J.F. et al. Orelha-de-negro (Enterolobium contortisiliquum (Vell.) Morong): dormência e métodos para a sua quebra. ÁRVORE, v.6, n.2, p.104-110, jul./dez. 1982.

FIGLIOLIA, M.B. Germinação de sementes de Cassia leptophylla Vog. sob diversos tratamentos para a quebra de dormência. SILVICULTURA EM SÃo PAULO, v.16A, parte2, p.901-907, 1982a. Edição Especial. Apresentado ao Congresso Nacional sobre Essências Nativas, Campos do Jordão, 1982 - Anais.

FIGLIOLIA, M.B.; SILVA, A.da Germinação de sementes beneficiadas e não beneficiadas de Peltophorum dubium (Spreng.) Taubert. Em laboratório e viveiro sob tratamentos pré-germinativos. SILVICULTURA EM SÃ O PAULO, v.16A, parte2, p.908-916, 1982b. Edição Especial. Apresentado ao Congresso Nacional sobre Essências Nativas, Campos do Jordão, 1982 - Anais.

GAVIDIA, A.T. Influência do fotoperiodo e embebição em água na germinação de sementes pré-tratadas de embaúva (Cecropia adenopus Mart.), e turco (Parkinsonia aculeata Linn.). FLORESTA, v.13, n.2, p.23, dezembro 1982.

PEDROSA, J.B. A candeia (Vanillosmopsis erythropappa) (DC) Selt. Et Bib. SILVICULTURA EM SÃO PAULO, v.16A, parte2, p.1132-1133, 1982. Edição Especial. Apresentado ao Congresso Nacional sobre Essências Nativas. Campos do Jordão. 1982 - Anais. 
PEREIRA, A.P. Ensaios em viveiro florestal e frutificação de algumas espécies amazônicas. SILVICULTURA EM SÃo PAULO, v.16A, parte2, p.1135-1138, 1982a. Edição Especial. Apresentado ao Congresso Nacional sobre Essências Nativas, Campos do Jordão, 1982 - Anais.

PEREIRA, A.P.; PEDROSO, L.M. Influência da profundidade de semeadura em algumas essências florestais da Amazônia. (I). SILVICULTURA EM SÃO PAULO, v.16A, parte2, p.1092-1099, 1982b. Edição Especial. Apresentado ao Congresso Nacional sobre Essências Nativas, Campos do Jordão, 1982 - Anais.

PEREIRA, A.P.; PEDROSO, L.M. Influência da profundidade de semeadura na germinação e vigor das mudas de Caryocar villosum (Caryocaraceae). SILVICULTURA EM SÃO PAULO, v.16A, parte2, p.1100-1104, 1982c. Edição Especial. Apresentado ao Congresso Nacional sobre Essências Nativas, Campos do Jordão, 1982 - Anais.

QUEIROZ, M.H.de Aspectos preliminares de beneficiamento e germinação de Miconia cinnamomifolia (De Candolle) Naudium - jacatirão-açu. SILVICULTURA EM SÃO PAULO, v.16A, partel, p. 318-321, 1982. Edição Especial. Apresentado ao Congresso Nacional sobre Essências Nativas, Campos do Jordão, 1982a - Anais.

QUEIROZ, M.H.de Triagem densimétrica e quebra de dormência em Columbrina glandulosa Perkins var. Reitzii (M.C.Jonston) M.C.Jonston. SILVICULTURA EM SĀO PAULO, v.16A, parte1, p.307-311, 1982. Edição Especial. Apresentado ao Congresso Nacional sobre Essências Nativas, Campos do Jordão, 1982b - Anais.

RAMOS, A. Influência de cinco tipos de embalagens na germinação e no vigor de sementes de angico Parapiptadenia rigida (Benth) Brenan, caixeta - Tabebuia cassionoides (LAM) DC. e caroba - Jacaranda micrantha Cham. Armazenadas em câmara fria e à temperatura ambiente. FLORESTA, v.13, n.2, p.21-22, dezembro 1982.

RANDI, A.M. Estudo preliminar sobre inibidores de germinação em frutos de Miconia cinnamomifolia e Ocotea puberula. SILVICULTURA EM SÃO PAULO, v.16A, parte1, p.238-242, 1982. Edição Especial. Apresentado ao Congresso Nacional sobre Essências Nativas, Campos do Jordão, 1982 - Anais.

SOUZA, S.M.de; LIMA, P.C.S. Caracterização de sementes de algumas espécies florestais nativas do Nordeste. SILVICULTURA EM SÃO PAULO, v.16A, parte2, p.1156-1167, 1982. Edição Especial. Apresentado ao Congresso Nacional sobre Essências Nativas, Campos do Jordão, 1982 - Anais.

1983: 11 trabalhos

BLANCHETTI, A.; RAMOS, A. Escarificação Ácida Associada a Estratificação em Areia Úmida para Uniformizar e Acelerar a Germinação de Sementes de Canela-Guaicá (Ocotea puberula NEES) em Laboratório. SILVICULTURA, n.28, p.181-182, 1983. Apresentado ao 4. Congresso Florestal Brasileiro, Belo Horizonte, 1982 - Anais.

BIANCHETTI, A.; RAMOS, A. Escarificação Ácida Associada a Estratificação Úmida para Uniformizar a Emergência de Plântulas de Canela-Guaicá (Ocotea puberula NEES) em Casa de Vegetação. SILVICULTURA, n.28, p.183-184, 1983. Apresentado ao 4. Congresso Florestal Brasileiro, Belo Horizonte, 1982 - Anais.

CAMPINHOS JÚNIOR, E.; IKEMORI, Y.K. Introdução de Nova Técnica na Produção de Mudas de Essências Florestais. SILVICULTURA, n.28, p.226-228, 1983. Apresentado ao 4. Congresso Florestal Brasileiro, Belo Horizonte, 1982 - Anais.

CARPANESSI, A.A.; KANASHIRO, M.; RODRIGUES, I.A. et al. Informações sobre Cordia alliodora (R. \& P.) OKEN na Amazônia Brasileira. SILVICULTURA, n.28, p.247-251, 1983. Apresentado ao 4. Congresso Florestal Brasileiro, Belo Horizonte, 1982 - Anais. 
MARQUES. L.C.T. Produção de Mudas de Freijó (Cordia goeldiana HUBER). SILVICULTURA, n.28, p.247-251, 1983. Apresentado ao 4. Congresso Florestal Brasileiro, Belo Horizonte, 1982 - Anais.

MARQUES, L.C.T.; BRIENZA JÚNIOR, S. Informações sobre Algumas Espécies Florestais em Fase de Viveiro na Amazônia Brasileira. SILVICULTURA, n.28, p.334-335, 1983. Apresentado ao 4. Congresso Florestal Brasileiro, Belo Horizonte, 1982 - Anais.

RAMOS, A.; BIANCHETTI, A.; KUNYIOSHI, Y.S. Influência do Tipo e da Espessura de Cobertura de Canteiros na Emergência e Vigor de Sementes de Angico - Parapiptadenia rigida (BENTH.) BRENAN. SILVICULTURA, n.28, p.446-448, 1983. Apresentado ao 4. Congresso Florestal Brasileiro, Belo Horizonte, 1982 - Anais.

STURION, J.A.; IEDE, E.T. Influência da Profundidade de Semeadura, Cobertura do Canteiro e Sombreamento na Formação de Mudas de Ocotea porosa (NEES) LIBERATO BARROSO (Imbuia). SILVICULTURA, n.28, p.513-516, 1983. Apresentado ao 4. Congresso Florestal Brasileiro, Belo Horizonte, 1982 - Anais.

VIANNA, N.G. Armazenamento de Sementes de Mogno (Swietenia macrophylla KING). SILVICULTURA, n.28, p.539-540, 1983. Apresentado ao 4. Congresso Florestal Brasileiro, Belo Horizonte, 1982 - Anais.

VIANNA, N.G. Conservação de Sementes de Andiroba (Carapa guianensis AUBL.) Acondicionadas em Diferentes Embalagens e sob Diversas Condições de Armazenagem. SILVICULTURA, n.28, p.544-545, 1983. Apresentado ao 4. Congresso Florestal Brasileiro, Belo Horizonte, 1982 - Anais.

VIANNA, N.G. Produção e Tecnologia de Sementes de Freijó (Cordia goeldiana HUBER). SILVICULTURA, n.28, p.541-543, 1983. Apresentado ao 4. Congresso Florestal Brasileiro, Belo Horizonte, 1982 - Anais.

\section{4: 1 trabalho}

FREITAS, S.C.de; CECON, P.R.; CANDIDO, J.F. Tamanho da amostra e tempo de secagem na determinação do teor de umidade de sementes de garapa (Apuleia leiocarpa (Vog.) Macbr.). ÁRVORE, v.8, n.2, p.85-92, jul./dez. 1984.

1985: 3 trabalhos

LUZ, H.F.; FERREIRA, M. Ipê-felpudo (Zeyhera tuberculosa (Vell) Bur.): essência pioneira com grande potencial silvicultural. IPEF, v.31, p.13-22, dezembro 1985.

REIS, G.G.dos; FREITAS, S.C.de Germinação de sementes de tento (Ormosia arborea (Vell.) Arms. Leguminosae - Faboidae). ÁRVORE, v.9, n.2, p.127-133, jul./dez. 1985a.

REIS, G.G.dos; BRUNE, A.; RENA, A.B. Estudos sobre a dormência de sementes de sucupira (Pterodon pubescens Benth): tratamentos para superação da dormência. ÁRVORE, v.9, n.1, p.49-57, jan./jul. 1985b.

1986: 9 trabalhos

ALBRECHT, J.MF.; NOGUEIRA, A.C. Influência do sombreamento sobre a germinação e produção de mudas de ipê (Tabebuia aurea Benth\&Hoock). SILVICULTURA, v.11, n.41, p.69, 1986. Apresentado ao 5. Congresso Florestal Brasileiro, Recife, 1986 - Anais.

ANTONIO, N.A.M.G.; AMARAL, D.M.I. Substrato e temperatura de germinação para sementes de pau-ferro (Astronium balansae Engl.). SILVICULTURA, v.11, n.41, p.72, 1986. Apresentado ao 5. Congresso Florestal Brasileiro, Recife. 1986 - Anais.

MALAVASI, U.C. Ecofisiologia comparativa de espécies florestais pioneiras e climaxes - variação na alocação de fotossintetato. SILVICULTURA, v.11, n.41, p.75, 1986. Apresentado ao 5. Congresso Florestal Brasileiro, Recife, 1986 - Anais. 
MEKDECE, F.S.; FERNANDES, R.S.R.S.; LOPES, C.A.C. Avaliação do comportamento de plântulas de Dipteryx odorata (Aubl) Wild (cumaru) em viveiro para produção de mudas. SILVICULTURA, v.11, n.41, p.66, 1986. Apresentado ao 5. Congresso Florestal Brasileiro, Recife, 1986 - Anais.

NODARI, R.O.; GUERRA, M.P.; REIS, A. Perspectivas do palmiteiro (Euterpe edulis) no Sul do Brasil. SILVICULTURA, v.11, n.41, p.75, 1986a. Apresentado ao 5. Congresso Florestal Brasileiro, Recife, 1986 - Anais.

NODARI, R.O.; GUERRA, M.P.; REIS, A. Resposta de mudas de Colubrina glandulosa Perkins var. Reitzii (M.C. Johnston) M.C. Johnston, a diferentes composições de substrato - fase de viveiro. SILVICULTURA, v.11, n.41, p.75, 1986b. Apresentado ao 5. Congresso Florestal Brasileiro, Recife, 1986 - Anais.

NUNES, M.N.; VARELA, V.P. Efeito do tratamento de sementes de cardeiro (Scleronema micranthum Ducke) - Bombacaceae, com fungicida e inseticida na germinação. SILVICULTURA, v.11, n.41, p.72, 1986. Apresentado ao 5. Congresso Florestal Brasileiro, Recife, 1986 - Anais.

RAGAGNIN, L.I.M.; DIAS, L.L.; ESTEFANEL, V. Maturação fisiológica de sementes de canafistula (Peltophorum dubium (Spreng.) Taub.). SILVICULTURA. v.11, n.41, p.70, 1986. Apresentado ao 5. Congresso Florestal Brasileiro, Recife, 1986 - Anais.

RODRIGUES, V.A. Ensaio com frutos e sementes de juazeiro. SILVICULTURA. v.11, n.41, p.75, 1986. Apresentado ao 5 . Congresso Florestal Brasileiro, Recife, 1986 - Anais.

\section{7: 3 trabalhos}

JESUS, R.M.; MENANDRO, M.S.; BATISTA, J.L.F.; COUTO, H.T.Z. Efeito do tamanho do recipiente, tipo de substrato e sombreamento na produção de mudas de Louro (Cordia trichotoma) e Gonçalo-Alves (Astronium fraxinifolium). IPEF, v.37, p.13-20, dezembro 1987.

JESUS, R.M.; MENANDRO, M.S.; BATISTA, J.L.F. Eficiência da repicagem na produção de mudas de Louro (Cordia trichotoma) e Gonçalo-Alves (Astronium fraxinifolium). IPEF, v.37, p.69-72, dezembro 1987.

REIS, G.G.dos; RENA, A.B. Estudo da dormência de sementes de sucupira (Pterodon pubescens Benth): viabilidade, perda e absorção de água, respiração e presença de inibidores. ÁRVORE, v.11, n.2, p. 105-118, jul./dez. 1987.

\section{8: 1 trabalho}

DANIEL, O.; REIS, M.G.F.; MAESTRI, M.; REIS, G.G.dos Germinação de sementes e sobrevivência inicial de plântulas de Astronium concinnum Schott (gonçalo-alves) em condições naturais. ÁRVORE, v.12, n.2, p.196-, jul./dez. 1988.

1990: 8 trabalhos

ALBRECHT, J.M.F; MOREIRA, I.P.S. Influência de diferentes niveis de sombreamento sobre a produção de mudas de cambará (Vockysia divergens). In: CONGRESSO FLORESTAL BRASLEIRO, 6., Campos do Jordão, 1990. Anais. Campos do Jordão: SBS/SBEF, 1990. v.3, p.574-575.

BARBOSA, A.P. O crescimento de mudas de caroba (Jacaranda copaia Aubl. D. Don - Bignoniaceae) cultivadas sob diferentes niveis de sombreamento e espaçamento. In: CONGRESSO FLORESTAL BRASILEIRO, 6., Campos do Jordão, 1990. Anais. Campos do Jordão: SBS/SBEF, 1990. v.3, p.526-534.

BARBOSA, A.P.; BARBOSA, L.M.; SILVA, T.S.da et al. Maturação de sementes de Acacia paniculata Wild. In: CONGRESSO FLORESTAL BRASILEIRO, 6., Campos do Jordão, 1990. Anais. Campos do Jordão: SBS/SBEF, 1990. v.3, p.535-537.

DANIEL, O.; OHASHI, S.T.; ROCHA, M.O. Avaliação de métodos para acelerar e elevar a capacidade de germinação de sementes de Goupia glabra, AUBL. In: CONGRESSO FLORESTAL BRASILEIRO, 6 ., Campos do Jordão, 1990. Anais. Campos do Jordão: SBS/SBEF, 1990. v.3, p.641-643. 
DRUMOND, M.A.; LIMA, P.C.F. Sombreamento na produção de mudas de leucena e cumbaru. In: CONGRESSO FLORESTAL BRASILEIRO, 6., Campos do Jordão, 1990. Anais. Campos do Jordão: SBS/SBEF, 1990. v.3, p.799.

ENGEL, V.L.; POGGIANI, F. Influência do sombreamento sobre o crescimento de mudas de algumas essências nativas e suas implicações ecológicas e silviculturais. IPEF, v.43/44, p.1-10, 1990.

MARTINS, E.G.; BIANCHETTI, A.; RAMOS, A. Estudos preliminares de processamento de sementes de bracatinga em protótipo de mesa de gravidade. In: CONGRESSO FLORESTAL BRASILEIRO, 6., Campos do Jordão, 1990. Anais. Campos do Jordão: SBS/SBEF, 1990. v.3, p.544-546.

QUEIROZ, M.H.de Considerações sobre a estratégia germinativa e distribuição de Alchomea triplinervia (SPR) M. Arg. Var. triplinervia na floresta tropical Atlântica em Santa Catarina. In: CONGRESSO FLORESTAL BRASILEIRO, 6., Campos do Jordão, 1990. Anais. Campos do Jordão: SBS/SBEF, 1990. v.3, p.613-615.

\section{1: 4 trabalhos}

ARAÚJO, S.S.; MATOS, V.P. Morfologia da semente e de plântulas de Cassia fistula L. ÁRVORE, v.15, n.3, p.217-223, set./dez. 1991 .

BORGES, EE.L.e; MORAES, G.H.K.de: CÂNDIDO, J.F.; REIS, F.P.; SIL VA, D.da Mobilização de reservas em sementes de angico-vermelho ( Piptadenia peregrina Benth) e armazenamento em diferentes recipientes e condições de ambientes. ÁRVORE, v.15, n.2, p.126-136, mai./ago. 1991.

REIS, M.G.F.; REIS, G.G.dos; REGAZZI, J.; LELES, P.S.S. Crescimento e forma do fuste de mudas de jacarandá-da-bahia (Dalbergia nigra Fr. Allem.) sob diferentes níveis de sombreamento e tempo de cobertura. ÁRVORE, v.15, n.1, p.23-34, jan./abr. 1991.

SILVA, L.M.M.; MATOS, V.P. Morfologia da semente e da germinação de Erytrina velutina Willd. ÁRVORE, v.15, n.2, p.137-143, mar.ago. 1991.

\section{2: 19 trabalhos}

AGUIAR, F.F.A.; KANASHIRO, S. Influência da calagem, adubação mineral e orgânica sobre o crescimento inicial do palmiteiro. Revista do Instituto Florestal, v.4, parte 2, p.630-633, 1992. Edição Especial. Apresentado ao 2. Congresso Nacional sobre Essências Nativas. São Paulo, 1992 - Anais.

BARBOSA, J.M.; AGUIAR, I.G.de; SANTOS, S.R.G.dos Maturação de sementes de Copaifera langsdorffii Desf. Revista do Instituto Florestal, v.4, parte 3, p.665-674, 1992. Edição Especial. Apresentado ao 2. Congresso Nacional sobre Essências Nativas, São Paulo, 1992 - Anais.

CUNHA, R.da; SALOMÃO, A.N., EIRA, M.T.S. et al. Métodos para conservação a longo prazo de sementes de Tabebuia sp - Bignoniaceae. Revista do Instituto Florestal. v.4, parte 3, p.675-678, 1992. Edição Especial. Apresentado ao 2. Congresso Nacional sobre Essências Nativas, São Paulo, 1992 - Anais.

COSTA FILHO, R.T.da Crescimento de mudas de aroeira (Astronium urundeuva) (Fr.All)Engl) em resposta à calagem, fósforo e potássio. Revista do Instituto Florestal. v.4, parte 2, p.537-543, 1992 . Edição Especial. Apresentado ao 2. Congresso Nacional sobre Essências Nativas, São Paulo, 1992 - Anais.

DIAS, L.E.; JUCKSCH, I. ALVAREZ, V.H.; BRIENZA JR, N.F.B.S. Formação de mudas de Taxi-Branco (Sclerolobium paniculatum Voguel): II. Resposta a nitrogênio, potássio e enxofre. ÁRVORE, v.16, n.2, p.135-143, mai./ago 1992.

DURAFLORA S.A. Equipe Técnica. Produção e manejo de mudas de espécies florestais nativas na Duraflora S.A., em Lençois Paulista - SP. Revista do Instituto Florestal. v.4, parte 3, p.692-694, 1992. Edição Especial. Apresentado ao 2. Congresso Nacional sobre Essências Nativas, São Paulo, 1992 - Anais. 
EIRA, M.T.S.; SAMOMÃO, A.N.; CUNHA, R.da et al. Conservação de sementes de Copaifera langsdorffii Desf. - Leguminosae. Revista do Instituto Florestal, v.4, parte 2, p.523-526, 1992. Edição Especial. Apresentado ao 2. Congresso Nacional sobre Essências Nativas, São Paulo, 1992 - Anais.

KAGEYAMA, P.Y.; SANCHEZ, S.P.A.; FERRAZ, E.M.; SOUZA, L.M.C. Armazenamento de sementes de três espécies nativas (Tabebuia heptaphylla, Erytrina verna e Chorisia speciosa). Revista do Instituto Florestal, v.4, parte 2, p.435-439, 1992. Edição Especial. Apresentado ao 2. Congresso Nacional sobre Essências Nativas, São Paulo, 1992 - Anais.

MAGALHÃES, P.M.de; FIGUEIRA, G.M.; PEREIRA, B.; MONTANARI JÚNIOR, I. Conservação da espécies Maytenus ilicifolia Mart. ex Reiss (espinheira santa) através de técnica de propagação de sementes. Revista do Instituto Florestal, v.4, parte 2, p.519-522, 1992. Edição Especial. Apresentado ao 2. Congresso Nacional sobre Essências Nativas, São Paulo, 1992 - Anais.

MALUF, A.M. Variação populacional na germinação e dormência de sementes de Senna multijuga. Revista do Instituto Florestal, v.4, parte 3, p.728-732, 1992. Edição Especial. Apresentado ao 2. Congresso Nacional sobre Essências Nativas, São Paulo, 1992 - Anais.

MARQUES, M.C.M.; PIMENTA, J.A.; COLLI, S. Germinação de Cedrela fissilis Vell e Parapiptadenia rigida (Benth) Bren. após pré-tratamento em condiçães hipóxicas e posterior estocagem a seco. Revista do Instituto Florestal, v.4, parte 2, p.620-624, 1992. Edição Especial. Apresentado ao 2. Congresso Nacional sobre Essências Nativas, São Paulo, 1992 - Anais.

MEDEIROS, A.C.S.; CZARNESKI, C.M.; FREITAS, G.F.de Criopreservação de sementes de aroeira (Astronium urundeuva (Fr. All) Engl.). Revista do Instituto Florestal, v.4, parte 2, p.544-547, 1992. Edição Especial. Apresentado ao 2. Congresso Nacional sobre Essências Nativas, São Paulo, 1992 - Anais.

OGA, F.M.; FONSECA, C.E.L.da; SILVA, J.A.da Influência da profundidade de semeadura e a luminosidade na germinação de sementes de cagaita (Eugenia dysenterica Mart.). Revista do Instituto Florestal, v.4, parte 2, p.634-639, 1992. Edição Especial. Apresentado ao 2. Congresso Nacional sobre Essências Nativas, São Paulo, 1992 - Anais.

POGGIANI, F.; BRUNI, S.; BARBOSA. E.S.Q. Efeito do sombreamento sobre o crescimento das mudas de três espécies florestais. Revista do Instituto Florestal, v.4, parte 2. p.564-569, 1992. Edição Especial. Apresentado ao 2. Congresso Nacional sobre Essências Nativas, São Paulo, 1992 - Anais.

REIS, M.S.dos; FRANCHINI. R.G.; REIS, A.; FANTINI, A.C. Variação no período germinativo em sementes de Euterpe edulius Martius procedentes da região de Morretes -PR. Revista do Instituto Florestal, v.4, parte 4, p.1252-1256, 1992. Edição Especial. Apresentado ao 2. Congresso Nacional sobre Essências Nativas, São Paulo, 1992 - Anais.

SALOMÃO, A.N.; CAVALLARI, D.A.N. Tecnologias para a conservação ex situ de germoplasma de Amburana cearensis (Fr.All.)A.C. Smith - Papilionaceae. Revista do Instituto Florestal, v.4, parte 4, p.1237-1240, 1992. Edição Especial. Apresentado ao 2. Congresso Nacional sobre Essências Nativas, São Paulo, 1992 - Anais.

SILVA, Ada; FIGLIOLIA, M.B.; GARCIA, E.E.C.; JARDIM, D.C.P. Comportamento de sementes de Gallesia gorarema (vell.) Mog. liofilizadas e fechadas à vácuo, em laboratório e viveiro. Revista do Instituto Florestal, v.4, parte 2, p.497-503, 1992. Edição Especial. Apresentado ao 2. Congresso Nacional sobre Essências Nativas, São Paulo, 1992 - Anais.

SILVA FILHO, N.L.da; BARBOSA, L.M.; SCAF, M.F ; KANAXIHRO, S. Expedição científica a rondônia Estudos de viabilidade de propagação de espécies vegetais. Revista do Instituto Florestal, v.4, parte 2 , p.609-619, 1992. Edição Especial. Apresentado ao 2. Congresso Nacional sobre Essências Nativas, São Paulo. 1992 - Anais. 
TAKAHASHI, L.Y.; MARTINS, S.S. Desenvolvimento de mudas visando sua utilização na arborização de ruas. Revista do Instituto Florestal, v.4, parte 2, p.553-557, 1992. Edição Especial. Apresentado ao 2. Congresso Nacional sobre Essências Nativas, São Paulo, 1992 - Anais.

1993: 12 trabalhos

AMARAL, W.A.N.do; KAGEYAMA, P.Y. Ecofisiologia da germinação e estabelecimento de plântulas de (Cytharexylum myrianthum) cham. In: CONGRESSO FLORESTAL BRASILEIRO, 7., Curitiba, 1993. Anais. Curitiba: SBS/SBEF, 1993, v.2, p.419-421.

BARBOSA, JM.; AGUIAR, I.B.de; SANTOS, S.R.G.dos; ZELLER, M.F.B. Efeito da cumarina na maturação de sementes de Copaifera langsdorfii desf. In: CONGRESSO FLORESTAL BRASILEIRO, 7., Curitiba, 1993. Anais. Curitiba: SBS/SBEF, 1993. v.2, p.422-439.

BARROSO, D.G.; TEIXEIRA, M.L.; MIRANDA, R.U.de; MARINHO, C.S. Tratamento pré-germinativo de sementes de 3 espécies nativas da Mata de Restinga da Região de mataraca - PB. In: CONGRESSO FLORESTAL BRASILEIRO, 7., Curitiba, 1993. Anais. Curitiba: SBS/SBEF, 1993. v.2, p.476-477.

DAVIDE, A.C.; FARIA, J.M.R; OLIVEIRA, L.M.de Quebra de dormência de candiúva (Trema micrantha (1.) blumeulmaceae. In: CONGRESSO FLORESTAL BRASILEIRO, 7., Curitiba, 1993. Anais. Curitiba: SBS/SBEF, 1993. v.2, p.461-462.

DRUMOND, M.A.; LIMA, P.C.F. Sombreamento na produção de mudas de Leucena e cumaru. In: CONGRESSO FLORESTAL BRASILEIRO, 7., Curitiba, 1993. Anais. Curitiba: SBS/SBEF, 1993. v.1, p.309-311.

FANTINI, A.C.; REIS, A.; REIS, M.S. et al. Caracterização de uma selecionada como "área de coleta de sementes" de palmiteiro (Euterpe edulis Martius) no Vale do Ribeira - SP. In: CONGRESSO FLORESTAL BRASILEIRO, 7., Curitiba, 1993. Anais. Curitiba: SBS/SBEF, 1993. v.2, p.410-411.

GANDARA, F.B.; LEPSH-CUNHA, N. Respostas da germinação de embaúba (Cecropia pachystachya) a diferentes tamanhos de clareira e periodos de luz. In: CONGRESSO FLORESTAL BRASILEIRO, 7., Curitiba, 1993. Anais. Curitiba: SBS/SBEF, 1993. v.2, p.467-469.

NOGUEIRA, A.C.; VAZ, E.T. Influência da profundidade de semeadura na germina;cão e desenvolvimento inicial de Dipteryx alata vog. In: CONGRESSO FLORESTAL BRASILEIRO, 7., Curitiba. 1993. Anais. Curitiba: SBS/SBEF, 1993. v.2, p.429-431.

SALOMÃO, A.N.; FUJICHIMA, A.G.; H. NETO, A.G. Qualidade fisiológica de sementes de Amburana cearensis (Fr. All.) A.C.Smith - Papilioneaceae de diferentes procedências e progênies. In: CONGRESSO FLORESTAL BRASILEIRO, 7., Curitiba, 1993. Anais. Curitiba: SBS/SBEF, 1993. v.2, p.457-460.

SCALON, S.P.Q.; ALVARENGA, A.A.de Efeito do sombreamento sobre a formação de mudas de pau-pereira (Platycyamus regnelli Benth). ÁRVORE, v.17, n.3, p.265-270, set./dez. 1993.

ZANON, A.; CARPANEZZI, A.A. Armazenamento de sementes de cabralea glaberrima a. Jussieu. In: CONGRESSO FLORESTAL BRASILEIRO, 7., Curitiba, 1993. Anais. Curitiba: SBS/SBEF, 1993. v.1, p.223-224.

ZANON, A.; CARPANEZZI, A.A. Influências da dormência tegumentar e do grau de maturação sobre a germinação de sementes de Hovenia dulcis thunb. In: CONGRESSO FLORESTAL BRASILEIRO, 7., Curitiba, 1993. Anais. Curitiba: SBS/SBEF, 1993. v.l, p.294-297.

1994: 2 trabalhos

DANIEL, O.; OHASHI, S.T.; SANTOS, RA.dos Produção de mudas de Goupia glabra (Cupiúba): efeito de niveis de sombreamento e tamanho de embalagens. ÁRVORE, v.18, n.1, p.1-13, jan./abr. 1994. 
REIS, G.G.dos; REIS, M.G.F.; PAULA, R.C.de; MAESTRI, M.; BORGES, E.E.L.e Crescimento e ponto de compensaçãolúmico em mudas de espécies florestais nativas submetidas a diferentes niveis de sombreamento. ÁRVORE, v.18, n.2, p.97-106, mai./ago. 1994.

1995: 7 trabalhos

BRAGA, F.A.; VALE, F.R.do; VENTORIM, E.A.; LOPES, G.A. Exigências Nutricionais de Quatro Espécies Florestais. ÁRVORE, v.19, n.1, p.18-31, jan./mar. 1995.

CHAVES, L.F.C.; BORGES, R.C.G.; NEVES, J.C.L.; REGAZZI, A.J. Crescimento de Mudas de Jacarandá-daBahia (Dalbergia nigra (Vell.) Fr. Allem.) em Resposta a Inoculação com Fungos Micorrizicos VesículoArbusculares em Diferentes Níveis de Fósforo no Solo. ÁRVORE, v.19, n.1, p.32-49, jan./mar. 1995.

FIRMINO, J.L.; SANTOS, D.S.B.dos; SANTOS, B.G.dos Utilização de alguns testes de viabilidade e vigor e composição química em sementes de cerejeira (Amburana acreana (Ducke) A.C. Smith). ÁRVORE, v.19, n.3, p.286-292, abr./jun. 1995.

MELLO, C.M.C.de; EIRA, M.T.S.da Conservação de sementes de ipês (Tabebuia spp.). ÁRVORE, v.19, n.4, p.427-432, out./dez. 1995.

MUNIZ, A.S.; SILVA, M.A.G.da Exigências Nutricionais de Mudas de Peroba-Rosa (Aspidosperma polyneuron Muller Argoviensis) em Solução Nutritiva. ÁRVORE, v.19, n.2, p.263-271, abr./jun. 1995.

SALOMÃO, A.N.; EIRA, T.S.da; CUNHA. R.da Efeito da temperatura na germinação de sementes de quatro árvores de Dalbergia nigra Fr. Allem. - Leguminosae. ÁRVORE, v.19, n.4, p.433-446, out./dez. 1995.

SLVA, M.A.G.da; MUNIZ, A.S.; Exigências Nutricionais de Mudas de Cedro (Cedrela fissilis Vellozo) em Solução Nutritiva. ÁRVORE, v.19, n.3, p.415-, jul./set. 1995.

1996: 3 trabalhos

BORGES, E.E.L.e; BORGES, R.C.G. Modificaçoes fisiológicas em sementes osmocondicionadas de jacarandáda-bahia (Dalbergia nigra (Vell.) Fr. All). FLORESTA, v.20, n.2, p.147-154, abr./jun. 1996.

CHAVES, M.M.F.C.; RAMALHO, R.S. Estudos morfológicos em sementes, plântulas e mudas de duas espécies arbóreas pioneiras da familia Asteraceae (Vanillosmopsis erythropappa Sch. Bip e Vernonia discolor. (Spreng.) Less). FLORESTA, v.20, n.1, p.1-8, jan./mar. 1996.

FERNÁNDEZ, J.Q.P.; RUIVO, M.L.P.; DIAS, L.E. et al. Crescimento de mudas de Mimosa tenuiflora submetidas a diferentes niveis de calagem e doses de fósforo, potássio e enxofre. FLORESTA, v. 20, n.4, p.425-432, out./dez.. 1996.

1997: 2 trabalhos

MONTEIRO, P.P.M.; RAMOS,F.A. Beneficiamento e quebra de dormência de sementes em cinco espécies florestais do cerrado. FLORESTA, v.21, n.2, p.169-174, abr.jun. 1997.

REIS, M.G.F.; REIS, G.G.dos; LELES, P.S.S. et al. Exigências nutricionais de mudas de Dalbergia nigra (Vell.) Fr. Allem (Jacarandá-da-bahia) produridas em dois níveis de sombreamento. FLORESTA, v.21, n.4, p.169174, out./dez. 1997.

\section{2) Competição de Espécies}

\section{3: 1 trabalho}

VASCONCELLOS, P.W.C. Competição entre guarantã, pau-rei e sapucaia, empregados como moirões de cerca. In: CONGRESSO FLORESTAL BRASILEIRO, 1., Curitiba, 1953a. Anais. Curitiba: Instituto Nacional do Pinho, 1953. p.205-207.

1975: 1 trabalho 
SILVA, L.B.X.; REICHMANN NETO, F. Parcelas permanentes e analises comparativas para espécies nativas e exóticas implantadas no sudoeste paranaende (Foz do Chopim/COPEL). FLORESTA, v.6, n.1, p.54-56, junho 1975.

1978: 6 trabalhos

ALENCAR, J.C.; FERNANDES, N.P. Desenvolvimento de Árvores Nativas em Ensaios de Espécies. 1 - Pau Rosa )Aniba Duckei Kostermans). Silvicultura, v.2, n.14, p.419-429, 1978. Edição Especial. Apresentado ao 3. CONGRESSO FLORESTAL BRASILEIRO, Manaus, 1978 - Anais.

CARVALHO, P.E.R.; STÖHR, G.W.D. Regeneração Artificial com Essências Nativas no Paraná. Silvicultura, v.2, n.14, p.82-84, 1978. Edição Especial. Apresentado ao 3. CONGRESSO FLORESTAL BRASILEIRO, Manaus, 1978 - Anais.

CARVALHO, P.E.R.; STÖHR, G.W.D. Regeneração Artificial com Essências Nativas no Paraná. FLORESTA, v.9, n.2, p.52-56, dezembro 1978.

GURGEL FILHO, O.A.; GARRIDO, L.M.A.G.; NETTO, S.M.R. Caracteres Silviculturais e Biométricos do Crescimento de Algumas Essências Nativas da Zona Temperada (1). Silvicultura. v.2, n. 14, p.60-81. 1978. Edição Especial. Apresentado ao 3. CONGRESSO FLORESTAL BRASILEIRO, Manaus, 1978 - Anais.

JANKAUSKIS, J.; BARROS, P.L.C.de; PAIVA, J.S.V.de et al. Características Silviculturais de Espécies Nativas e Exóticas dos Plantios do Centro de Tecnologia da Madeira de Curuá-Una. Silvicultura, v.2, n.14, p.434-437, 1978. Edição Especial. Apresentado ao 3. CONGRESSO FLORESTAL BRASILEIRO, Manaus, 1978 - Anais.

YARED, J.A.G.; CARPANEZZI, A.A.; CARVALHO FILHO, A.P. Ensaio de Espécies em Várias Áreas da Região Amazônica. Silvicultura, v.2, n.14, p.438-441, 1978. Edição Especial. Apresentado ao 3. CONGRESSO FLORESTAL BRASILEIRO, Manaus, 1978 - Anais.

1979: 1 trabalho

GALVÃO, A.P.M.; FERREIRA, C.A.; TEIXEIRA, L.B. Observações sobre o comportamento de jacarandá-dabahia (Dalbergia nigra Fr. Allem.) em povoamento puro na Amazônia. IPEF, v.19, p.47-62, dezembro 1979.

1980: 1 trabalho

BATISTA, M.P.; WOESSNER, R.A. Comparação do incremento em altura e diâmetro de espécies nativas e exóticas no nordeste do Pará, Brasil. FLORESTA. v.11, n.1, p.24-32, junho 1980.

1982: 6 trabalhos

GURGEL FILHO, O.A.; MORAES, J.L.; GARRIDO, L.M.A.G. Espécies nativas euxilóforas. SILVICULTURA EM SÃo PAULO, v. 16A, parte2, p.890-894, 1982. Edição Especial. Apresentado ao Congresso Nacional sobre Essências Nativas, Campos do Jordão, 1982 - Anais.

GURGEL FILHO, O.A.; MORAES, J.L.; MORAIS, E. Caracteres silviculturais e competição entre espécies folhosas. SHVICULTURA EM SÃO PAULO, v.16A, parte2, p.895-900, 1982. Edição Especial. Apresentado ao Congresso Nacional sobre Essências Nativas, Campos do Jordão, 1982 - Anais.

LIMA, P.C.F.; SOUZA, S.M.de; DRUMOND, M.A. Competição de espécies florestais nativas em Petrolina PE. SILVICULTURA EM SÃo PAULO, v.16A, parte2, p.1139-1148, 1982. Edição Especial. Apresentado ao Congresso Nacional sobre Essências Nativas, Campos do Jordão, 1982 - Anais.

MENDES, C.J.; REZENDE, G.C.de; SUITER FILHO, W.; MORAES, T.S.A. Considerações sobre o potencial silvicultural e energético de quatro espécies nativas. SILVICULTURA EM SÃO PAULO, v. 16A, parte2, p.1350-1359, 1982. Edição Especial. Apresentado ao Congresso Nacional sobre Essências Nativas, Campos do Jordão, 1982 - Anais. 
NOGUEIRA, J.C.B.; SIQUEIRA, A.C.M.F.; GARRIDO, M.A.O. et al. Ensaio de competição de algumas essências nativas em diferentes regiões do Estado de São Paulo. SILVICULTURA EM SÃo PAULO, v.16A, parte2, p.1051-1053, 1982. Edição Especial. Apresentado ao Congresso Nacional sobre Essências Nativas, Campos do Jordão, 1982 - Anais.

TOLEDO FILHO, D.V.de; PARENTE, P.R. Essências indigenas sombreadas. SILVICULTURA EM SÃO PAULO, v.16A, parte2, p.948-956, 1982. Edição Especial. Apresentado ao Congresso Nacional sobre Essências Nativas, Campos do Jordão, 1982 - Anais.

\section{3: 5 trabalhos}

CARVALHO, P.E.R. Comportamento de Essências Florestais Nativas e Exóticas em Dois Locais do Estado do Paraná. SILVICULTURA, n.28, p.262-266, 1983. Apresentado ao 4. Congresso Florestal Brasileiro, Belo Horizonte, 1982 - Anais.

FERNANDES, N.P.; JARDIM, F.C.S. Desenvolvimento de Árvores Nativas em Ensaios de Espécies. 3 Cedrorana (Cedrelinga catenaeformis DUCKE). SILVICULTURA, n.28, p.278-281. 1983. Apresentado ao 4. Congresso Florestal Brasileiro, Belo Horizonte. 1982 - Anais.

GARRIDO, M.A.O.; SOUZA, A.C.de Manejo Científico de Povoamentos Florestais de Espécies Indígenas. SILVICULTURA, n.28, p.60-63, 1983. Apresentado ao 4. Congresso Florestal Brasileiro, Belo Horizonte, 1982 - Anais.

MENDES, C.J.; TORQUATO, M.C.; MORAES, T.S.A. et al. Plantios Homogêneos com 8 Espécies Nativas no Vale do Rio Doce. SILVICULTURA. n.28, p.350-352, 1983. Apresentado ao 4. Congresso Florestal Brasileiro, Belo Horizonte, 1982 - Anais.

PIRES, IE.; FERREIRA, C.A. Potencialidade do Nordeste do Brasil para Reflorestamento. SILVICULTURA, n.28, p.440-445, 1983. Apresentado ao 4. Congresso Florestal Brasileiro, Belo Horizonte, 1982 - Anais.

\section{6: 2 trabalhos}

MARTINS, S.S. Estudo do comportamento silvicultural de espécies nativas em plantios de enriquecimento (Nota Prévia). SILVICULTURA, v.8, n.41, p.118, 1986. Apresentado ao 5. Congresso Florestal Brasileiro, Recife, 1986 - Anais.

SILVA, L.B.X.da; REICHMANN NETO, R. Avaliação do comportamento de 18 espécies florestais aos 10 anos de implantação. SILVICULTURA, v.8. n.41, p.101-104, 1986. Apresentado ao 5. Congresso Florestal Brasileiro, Recife, 1986 - Anais.

1990: 3 trabalhos

BRIENZA JUNIOR, S.; CASTRO, R.C.A.de; VIANA, L.M. Ensaio de espécies florestais sob duas diferentes condições ecológicas: 1. avaliações silviculturais. In: CONGRESSO FLORESTAL BRASILEIRO, 6. Campos do Jordão, 1990. Anais. Campos do Jordão: SBS/SBEF, 1990. v.3, p.616-623. 
GARRIDO, M.A.O.; DOMINGOS, P.R.; GARRIDO, L.M.A.G.; DURIGAN, G. Pesquisa e experimentação com cinco espécies nativas. In: CONGRESSO FLORESTAL BRASILEIRO, 6., Campos do Jordão, 1990. Anais. Campos do Jordão: SBS/SBEF, 1990. v.3, p.602-609.

SILVA, L.B.X.da; REICHMANN NETTO, F. Avaliação comparativa do desenvolimento de 26 espécies florestais em plantios homogêneos no sudeste paranaense. In: CONGRESSO FLORESTAL BRASILEIRO, 6., Campos do Jordão, 1990. Anais. Campos do Jordão: SBS/SBEF, 1990. v.3, p.649-657.

1992: 3 trabalhos

BERTONI, J.E.A. Reflorestamento com essências nativas e regeneração natural do cerrado. Revista do Instituto Florestal, v.4, parte 3, p.706-709, 1992. Edição Especial. Apresentado ao 2. Congresso Nacional sobre Essências Nativas, São Paulo, 1992 - Anais.

JESUS, R.M.de; GARCIA, A.; TSUTSUMI, I. Comportamento de doze espécies florestais da Mata Atlântica em povoamentos puros. Revista do Instituto Florestal, v.4, parte 2, p.491-496, 1992. Edição Especial. Apresentado ao 2. Congresso Nacional sobre Essências Nativas, São Paulo, 1992 - Anais.

SILVA, L.B.X.da; TORRES, M.A.V. Espécies florestais cultivadas pela Copel - PR (1974-1988). Revista do Instituto Florestal, v.4, parte 2, p.585-594, 1992. Edição Especial. Apresentado ao 2. Congresso Nacional sobre Essências Nativas, São Paulo, 1992 - Anais.

1993: 1 trabalho

SLVA, L.B.X.da; TORRES, M.A.V. Reflorestamento misto x puro - Foz do Chopim (1979 - 1991) Copel Paraná. In: CONGRESSO FLORESTAL BRASILEIRO, 7., Curitiba, 1993. Anais. Curitiba: SBS/SBEF, 1993. v.2, p.463-466.

\section{3) Melhoramento Genético}

\section{1) Teste de Procedência}

\section{1: 1 trabalho}

BALDANZI, G.; ARAÚJO, A.J.de Investigaç̃̃es sobre a variação geográfica na Araucaria angustifolia, na Estação de Pesquisas Florestais de Rio Negro, Paraná. FLORESTA, v.3, n.2, p.37-42, novembro 1971.

1973: 2 trabalhos

BALDANZI, G.; RITTERSHOFER, F.O.; REISSMANN, C.B. Ensaio comparativo de procedências de Araucaria angustifolia (Bert.) O. Ktze. In: CONGRESSO FLORESTAL BRASILEIRO, 2.,Curitiba, 1973. Anais. Curitiba: 1973. p.123.

INOUE, M.T. Ensaio de Procedência de Cedrela em Santo Antônio da Platina - PR. FLORESTA, v.4, n.2, p.49-57, setembro 1973 .

\section{2: 7 trabalhos}

BATISTA, M.P.; BORGES, J.F.; BRANCO, M.A.B. Avaliação do crescimento inicial de uma essência nativa em comparação com outras exóticas, no Nordeste do Pará, Brasil. SILVICULTURA EM SÃO PAULO, v.16A, parte2, p.1105-1110, 1982. Edição Especial. Apresentado ao Congresso Nacional sobre Essências Nativas, Campos do Jordão, 1982 - Anais.

GIANNOTTI, E.; TIMONI, J.L.; MARIANO, G. et al. Variação genética entre procedências e progênies de Araucaria angustifolia (Bert.) O.Ktze. SILVICULTURA EM SÃO PAULO, v.16A, parte2, p.970-975, 1982. Edição Especial. Apresentado ao Congresso Nacional sobre Essências Nativas, Campos do Jordão, 1982 - Anais. 
MONTEIRO, R.F.R; SPELTZ, RM.; GURGEL, J.T.A. Comportamento silvicultural de 24 raças geográficas de Araucaria angustifolia (Bert.) O.Ktze, no Paraná. SILVICULTURA EM SÃO PAULO, v.16A, parte2, p.814-824, 1982. Edição Especial. Apresentado ao Congresso Nacional sobre Essências Nativas, Campos do Jordão, 1982 - Anais.

NOGUEIRA, J.C.B.; SIQUEIRA, A.C.M.F.; MORAIS, E. et al. Conservação genética de essências nativas através de ensaios de progênie e procedência. SILVICULTURA EM SÃO PAULO, v. 16A, parte2, p.957969, 1982. Edição Especial. Apresentado ao Congresso Nacional sobre Essências Nativas, Campos do Jordão, 1982 - Anais.

PIRES, C.L.S.; KALIL FILHO, A.N.; ROSA, P.R.F.da et al. Teste de origens de Cordia alliodora (R.\&P.) Oken no Estado de São Paulo. SILVICULTURA EM SÃO PAULO, v. 16A, parte2, p.988-995, 1982. Edição Especial. Apresentado ao Congresso Nacional sobre Essências Nativas, Campos do Jordão, 1982 - Anais.

SIQUEIRA, A.C.M.F.; NOGUEIRA, J.C.B.; MURGEL, J.M.T. et al. Teste de progênie e procedência de cumbarú - Dipteryx alata Vog. SILVICULTURA EM SÃO PAULO, v.16A, parte2, p.1076-1080, 1982. Edição Especial. Apresentado ao Congresso Nacional sobre Essências Nativas, Campos do Jordão, 1982 . Anais.

VIANA, V.M. Conservação genética "ex situ" do ipê-felpudo (Zeyhera tuberculosa). SILVICULTURA EM SÃO PAULO, v. 16A, parte2, p.1028-1031, 1982. Edição Especial. Apresentado ao Congresso Nacional sobre Essências Nativas, Campos do Jordão, 1982 - Anais.

1983: 3 trabalhos

CARPANESSI, A.A.; KANASHIRO, M.; RODRIGUES, I.A. et al. Informações sobre Cordia alliodora (R. \& P.) OKEN na Amazônia Brasileira. SILVICULTURA, n.28, p.247-251, 1983. Apresentado ao 4. Congresso Florestal Brasileiro, Belo Horizonte, 1982 - Anais.

NOGUEIRA, J.C.B.; SIQUEIRA, A.C.M.F; MORAIS, E. et al. Conservação Genética de Essências Nativas Através de Ensaios de Progênies e Procedências. SHLVICULTURA, n.28, p.391-397, 1983. Apresentado ao 4. Congresso Florestal Brasileiro, Belo Horizonte, 1982 - Anais.

SIQUEIRA, A.C.M.F.; NOGUEIRA, J.C.B.; MURGEL, J.M.T. et al. Teste de Progênie e Procedência do Cumbaru - Dipteryx Alata VOG. SILVICULTURA, n.28, p.508-510, 1983. Apresentado ao 4. Congresso Florestal Brasileiro, Belo Horizonte, 1982 - Anais.

1985: 1 trabalho

LUZ, H.F.; FERREIRA, M. KAGEYAMA, P.Y. Teste de procedência de Ipê Felpudo (Zeyhera tuberculosa Bur.): resultados da primeira avaliação aos 12 meses. IPEF, v.30, p.55-58, agosto 1985 .

1986: 7 trabalhos

LUZ, H.F.; FERREIRA, M. KAGEYAMA, P.Y. Conservação Genética do Ipê Felpudo (Zeyhera tuberculosa (Vell.) Bur.). SILVICULTURA, v.8, n.41, p.68, 1986. Apresentado ao 5. Congresso Florestal Brasileiro, Recife, 1986 - Anais.

NOGUEIRA, J.C.B.; SIQUEIRA, A.C.M.F; MORAIS, E. et al. Estudos de progênies e procedências do amendoim Pterogyne nitens Tul. SILVICULTURA, v.8, n.41, p.115, 1986. Apresentado ao 5. Congresso Florestal Brasileiro, Recife, 1986 - Anais.

NOGUEIRA. J.C.B.; SIQUEIRA, A.C.M.F.; MORAIS, E. et al. Teste de progênies e procedência da aroeira Astronium urundeuva (Fr. All.) Engl. SILVICULTURA, v.8, n.41, p.116, 1986. Apresentado ao 5. Congresso Florestal Brasileiro, Recife, 1986 - Anais. 
NOGUEIRA, J.C.B.; SIQUEIRA. A.C.M.F; ZANATTO. A.C.S. et al. Teste de progênies e procedência do paud'alho - Gallesia gorarema Vell. MOQ. SILVICULTURA, v.8, n.41, p.115, 1986. Apresentado ao 5. Congresso Florestal Brasileiro, Recife. 1986 - Anais.

SIQUEIRA, A.C.M.F; NOGUEIRA, J.C.B.; MORAIS, E. et al. O cumbaru - Dypteryx alata Vog. Estudo de diferentes procedências e progênies. SILVICULTURA, v.8, n.41, p.113, 1986. Apresentado ao 5. Congresso Florestal Brasileiro, Recife, 1986 - Anais.

SIQUEIRA, A.C.M.F; NOGUEIRA, J.C.B.; ZANATTO, A.C.S. et al. Conservação dos Recursos Genéticos da Guarucaia - Peltophorum dubium (SPRENG.) TAUB. SILVICULTURA, v.8, n.41, p.113, 1986. Apresentado ao 5. Congresso Florestal Brasileiro, Recife, 1986 - Anais.

SIQUEIRA, A.C.M.F.; NOGUEIRA, J.C.B.; ZANATTO, A.C.S. et al. O Jequitibá-Rosa - Cariniana legalis (Mart) O.Ktze. Uma espécie em extinção. SILVICULTURA, v.8, n.41, p.113, 1986. Apresentado ao 5. Congresso Florestal Brasileiro, Recife, 1986 - Anais.

1993: 1 trabalho

NODARI, R.O.; REIS, M.S.; FANTINI, A.C. et al. Teste de procedência e progênie de Euterpe edulis - I. Procedência Saí-Guaçu e Itapocu, Vales do Mampituba e Araranguá e médio Vale do Itajaí-Açu. In: CONGRESSO FLORESTAL BRASILEIRO, 7., Curitiba, 1993. Anais. Curitiba: SBS/SBEF, 1993. v.2, p.470-472.

3.2) Teste de Progênies

1982: 3 trabalhos

GIANNOTTI, E.; TIMONI, J.L.; MARIANO, G. et al. Variação genética entre procedências e progênies de Araucaria angustifolia (Bert.) O.Ktze. SILVICULTURA EM SÃO PAULO, v.16A, parte2, p.970-975, 1982. Edição Especial. Apresentado ao Congresso Nacional sobre Essências Nativas, Campos do Jordão, 1982 - Anais.

NOGUEIRA, J.C.B.; SIQUEIRA, A.C.M.F.; MORAIS, E. et al. Conservação genética de essências nativas através de ensaios de progênie e procedência. SILVICULTURA EM SÃO PAULO, v.16A, parte2, p.957969, 1982. Edição Especial. Apresentado ao Congresso Nacional sobre Essências Nativas, Campos do Jordão, 1982 - Anais.

SIQUEIRA, A.C.M.F.; NOGUEIRA, J.C.B.; MURGEL, J.M.T. et al. Teste de progênie e procedência de cumbarú - Dipteryx alata Vog. SILVICULTURA EM SÃO PAULO, v. 16A, parte2, p. 1076-1080, 1982. Edição Especial. Apresentado ao Congresso Nacional sobre Essências Nativas, Campos do Jordão, 1982 Anais.

1983: 3 trabalhos

NOGUEIRA, J.C.B.; SIQUEIRA, A.C.M.F.; MORAIS, E. et al. Conservação Genética de Essências Nativas Através de Ensaios de Progênies e Procedências. SILVICULTURA, n.28, p.391-397, 1983. Apresentado ao 4. Congresso Florestal Brasileiro. Belo Horizonte. 1982 - Anais.

PIRES, C.L.S.; BARBIN, D.; GURFINKEL, J.; MARCONDES, M.A.P. Teste de Progênie de Araucaria angustifolia (BERT.) O.K. em Campos do Jordão. SILVICULTURA, n.28, p.437-439, 1983. Apresentado ao 4. Congresso Florestal Brasileiro. Belo Horizonte, 1982 - Anais.

SIQUEIRA, A.C.M.F; NOGUEIRA, J.C.B.; MURGEL, J.M.T. et al. Teste de Progênie e Procedência do Cumbaru - Dipteryx Alata VOG. SILVICULTURA. n.28, p.508-510, 1983. Apresentado ao 4. Congresso Florestal Brasileiro, Belo Horizonte, 1982 - Anais.

1986: 7 trabalhos 
LUZ, H.F.; FERREIRA, M. KAGEYAMA, P.Y. Conservação Genética do Ipê Felpudo (Zeyhera tuberculosa (Vell.) Bur.). SILVICULTURA, v.8, n.41, p.68, 1986. Apresentado ao 5. Congresso Florestal Brasileiro, Recife, 1986 - Anais.

NOGUEIRA, J.C.B.; SIQUEIRA, A.C.M.F.; MORAIS, E. et al. Estudos de progênies e procedências do amendoim Pterogyne nitens Tul. SILVICULTURA, v.8, n.41, p.115, 1986. Apresentado ao 5. Congresso Florestal Brasileiro, Recife, 1986 - Anais.

NOGUEIRA, J.C.B.; SIQUEIRA, A.C.M.F.; MORAIS, E. et al. Teste de progênies e procedência da aroeira Astronium urundeuva (Fr. All.) Engl. SILVICULTURA, v.8, n.41, p.116, 1986. Apresentado ao 5. Congresso Florestal Brasileiro, Recife, 1986 - Anais.

NOGUEIRA, J.C.B.; SIQUEIRA, A.C.M.F.; ZANATTO, A.C.S. et al. Teste de progênies e procedência do paud'alho - Gallesia gorarema Vell. MOQ. SILVICULTURA, v.8, n.41, p.115, 1986. Apresentado ao 5. Congresso Florestal Brasileiro. Recife, 1986 - Anais.

SIQUEIRA, A.C.M.F.; NOGUEIRA, J.C.B.; MORAIS, E. et al. O cumbaru - Dypteryx alata Vog. Estudo de diferentes procedências e progênies. SILVICULTURA. v.8, n.41, p.113, 1986. Apresentado ao 5. Congresso Florestal Brasileiro, Recife, 1986 - Anais.

SIQUEIRA, A.C.M.F.; NOGUEIRA, J.C.B.; ZANATTO, A.C.S. et al. Conservação dos Recursos Genéticos da Guarucaia - Peltophonum dubium (SPRENG.) TAUB. SILVICULTURA, v.8, n.41, p.113, 1986. Apresentado ao 5. Congresso Florestal Brasileiro, Recife, 1986 - Anais.

SIQUEIRA. A.C.M.F.; NOGUEIRA, J.C.B.; ZANATTO, A.C.S. et al. O Jequitibá-Rosa - Cariniana legalis (Mart) O.Ktze. Uma espécie em extinção. SILVICULTURA, v.8, n.41, p.113, 1986. Apresentado ao 5. Congresso Florestal Brasileiro, Recife. 1986 - Anais.

1990: 1 trabalho

SAMPAIO, P.T.B.; VENTURIERI, G.A. Variação genética entre e dentro de progênies de quatro espécies leguminosas: Copaifera multijuga HAYNE; Hymenaea courbaril LINN; Apuleia leiocarpa e Hymenolobium sp. In: CONGRESSO FLORESTAL BRASILEIRO, 6., Campos do Jordão, 1990. Anais. Campos do Jordão: SBS/SBEF, 1990. v.3, p.633-634.

1992: 2 trabalhos

MORAES, M.L.T.de; KAGEYAMA, P.Y.; SIQUEIRA, A.C.M.F. et al. Variação genética em duas populações de aroeira (Astronium urundeuva (Fr. All.) - Engl - Anacardiaceae). Revista do Instituto Florestal, v.4, parte 4, p.1241-1245, 1992. Edição Especial. Apresentado ao 2. Congresso Nacional sobre Essências Nativas, São Paulo, 1992 - Anais.

VITI, A.P.; KAGEYAMA. P.Y.; COSTA, L.G.S. et al. Estrutura genética em populações de Cecropia cinerea e Esenbeckia leiocarpa plantadas segundo a sucessão secundária. Revista do Instituto Florestal, v.4, parte 4, p.1209-1212, 1992. Edição Especial. Apresentado ao 2. Congresso Nacional sobre Essências Nativas, São Paulo, 1992 - Anais.

1993: 2 trabalhos

KAGEYAMA, P.Y.; SAKAVICIUS, A.; GERES, W.L.A. et al. Teste de progênie combinado de espécies pioneiras e climacicas. In: CONGRESSO FLORESTAL BRASILEIRO, 7., Curitiba. 1993. Anais. Curitiba: SBS/SBEF, 1993. v.2, p.476-477.

NODARI, R.O.; REIS, M.S.; FANTINI, A.C. et al. Teste de procedência e progênie de Euterpe edulis - I. Procedência Sai-Guaçu e Itapocu. Vales do Mampituba e Araranguá e médio Vale do Itajaí-Açu. In: CONGRESSO FLORESTAL BRASILEIRO, 7., Curitiba, 1993. Anais. Curitiba: SBS/SBEF, 1993. v.2, p.470-472. 


\section{3) Biotecnologia}

1975: 1 trabalho

KAGEYAMA, P.Y.; FERREIRA, M. Propagação vegetativa por enxertia com Araucaria angustifolia (Bert.)O.Ktze. IPEF, v.11, p.95, outubro 1995.

\section{2: 2 trabalhos}

BERGAMASCO, A. Comportamento do guarantã (Esenbeckia leiocarpa Engl) frente à enxertia como método de propagação. SILVICULTURA EM SÃO PAULO, v.16A, parte2, p.917-918, 1982. Edição Especial. Apresentado ao Congresso Nacional sobre Essências Nativas, Campos do Jordão, 1982 - Anais.

SILVA. A.Ada Propagação vegetativa de essências florestais nativas. SILVICULTURA EM SÃO PAULO, v.16A, parte2, p.934-947, 1982. Edição Especial. Apresentado ao Congresso Nacional sobre Essências Nativas, Campos do Jordão, 1982 - Anais.

\section{3: 2 trabalhos}

IRITANI, C.; SOARES, R.V. Indução do Enraizamento de Estacas de Araucaria angustifolia através da Aplicação de Reguladores de Crescimento. SILVICULTURA, n.28, p.313-317, 1983. Apresentado ao 4 . Congresso Florestal Brasileiro, Belo Horizonte, 1982 - Anais.

KANASHIRO, M. Propagação Vegetativa de Cordia goeldiana HUBER. SILVICULTURA, n.28, p.329-330, 1983. Apresentado ao 4. Congresso Florestal Brasileiro, Belo Horizonte, 1982 - Anais.

1986: 1 trabalho

CABRAL, I.C. Germinação de embriões de babaçu "in vitro", SILVICULTURA, v.8, n.41, p.68, 1986. Apresentado ao 5. Congresso Florestal Brasileiro, Recife, 1986 - Anais.

1992: 7 trabalhos

CUNHA, R.da; SALOMÃO, A.N., EIRA, M.T.S. et al. Métodos para conservação a longo prazo de sementes de Tabebuia sp - Bignoniaceae. Revista do Instituto Florestal, v.4, parte 3, p.675-678, 1992. Edição Especial. Apresentado ao 2. Congresso Nacional sobre Essências Nativas, São Paulo, 1992 - Anais.

EIRA, M.T.S.; SAMOMÃO, A.N.; CUNHA, R.da et al. Conservação de sementes de Copaifera langsdorffii Desf. - Leguminosae. Revista do Instituto Florestal. v.4, parte 2, p.523-526, 1992. Edição Especial. Apresentado ao 2. Congresso Nacional sobre Essências Nativas, São Paulo, 1992 - Anais.

GUERRA, M.P.; KEMPER, E.L. Tecnologia futuras: aplicação da poliembriogenese para a propagação massal de plantas elite de Araucaria angustifolia (Bert.) O.Kuntze. Revista do Instituto Florestal, v.4, parte 4, p.1233-1236, 1992. Edição Especial. Apresentado ao 2. Congresso Nacional sobre Essências Nativas, São Paulo, 1992 - Anais.

MAGALHÃES, P.M.de; FIGUEIRA, G.M.; PEREIRA. B.; MONTANARI JÚNIOR. I. Conservação da espécies Maytenus ilicifolia Mart. ex Reiss (espinheira santa) através de técnica de propagação de sementes. Revista do Instituto Florestal. v.4, parte 2, p.519-522, 1992. Edição Especial. Apresentado ao 2. Congresso Nacional sobre Essências Nativas, São Paulo, 1992 - Anais.

MEDEIROS, A.C.S.; CZARNESKI, C.M.; FREITAS, G.F.de Criopreservação de sementes de aroeira (Astronium urundeuva (Fr. All) Engl.). Revista do Instituto Florestal, v.4, parte 2, p.544-547, 1992. Edição Especial. Apresentado ao 2. Congresso Nacional sobre Essências Nativas, São Paulo, 1992 - Anais.

SALOMÃO, A.N.; CAVALLARI, D.A.N. Tecnologias para a conservação ex situ de germoplasma de Amburana cearensis (Fr.All.)A.C. Smith - Papilionaceae. Revista do Instituto Florestal, v.4, parte 4, p.1237-1240, 1992. Edição Especial. Apresentado ao 2. Congresso Nacional sobre Essências Nativas, São Paulo, 1992 - Anais. 
SILVA FILHO, N.L.da; BARBOSA, L.M.; SCAF, M.F.; KANAXHIRO, S. Expedição científica a rondônia Estudos de viabilidade de propagação de espécies vegetais. Revista do Instituto Florestal, v.4, parte 2, p.609-619, 1992. Edição Especial. Apresentado ao 2. Congresso Nacional sobre Essências Nativas, São Paulo, 1992 - Anais.

1993: 4 trabalhos

GUERRA, M.P.; LUCCA, P.de; NIETSCHE, S.; KEMPER, E. Biotecnologia de coníferas: indução e estabelecimento de linhagens celulares poliembriogênicas de Araucaria angustifolia e Pinus elliottii var. elliottii. In: CONGRESSO FLORESTAL BRASLEIRO, 7., Curitiba, 1993. Anais. Curitiba: SBS/SBEF, 1993. v.1, p.87-90.

NASCIMENTO, C.E.S.; OLIVEIRA, V.R.de; NUNES, R.F.M.; ALBUQUERQUE, T.C.S.de Propagação vegetativa do umbuzeiro. In: CONGRESSO FLORESTAL BRASILEIRO, 7., Curitiba, 1993. Anais. Curitiba: SBS/SBEF, 1993. v.2, p.454-456.

ROSA, L.S. Influência de diferentes concentrações de ácido indol 3 - butírico e do tamanho da estaca na formação de raizes adventícias em Carapa guianensis aubl. In: CONGRESSO FLORESTAL BRASILEIRO, 7., Curitiba, 1993. Anais. Curitiba: SBS/SBEF, 1993. v.2, p.432-433.

SOBRAL, B.W.S. Biotecnologia no melhoramento genético das espécies florestais. In: CONGRESSO FLORESTAL BRASILEIRO, 7., Curitiba, 1993. Anais. Curitiba: SBS/SBEF, 1993. v.1, p.139-141.

\section{4) Outros}

1983: 2 trabalhos

KANASHIRO, M. Melhoramento Genético do Freijó (Cordia goeldiana HUBER). SILVICULTURA, n.28, p.327-328, 1983. Apresentado ao 4. Congresso Florestal Brasileiro, Belo Horizonte, 1982 - Anais.

VIANA, V.M. Conservação e Variabilidade Genética do Ipê Felpudo (Zeyhera tuberculosa). SLLICULTURA, n.28, p.537-538, 1983. Apresentado ao 4. Congresso Florestal Brasileiro, Belo Horizonte, 1982 - Anais.

1984: 1 trabalho

ZANI FILHO, F.; KAGEYAMA, P.Y. A produção de sementes melhoradas de espécies florestais, com ênfase em Eucalyptus. IPEF, v.27, p. 49-52, agosto 1984.

1986: 4 trabalhos

BOVI, M.L.A.; GODOY JÚNIOR, G.; SAES, L.A. Híbridos interespecificos de palmiteiro (Euterpe oleracea x Euterpe edulis). SILVICULTURA, v.8, n.41, p.117, 1986. Apresentado ao 5. Congresso Florestal Brasileiro, Recife, 1986 - Anais.

CABRAL, I.C. Estaquia do Mogno. SILVICULTURA, v.8, n.41, p.68, 1986. Apresentado ao 5. Congresso Florestal Brasileiro, Recife. 1986 - Anais.

CABRAL, I.C. Propagação Vegetativa do Freijó (Cordia goeldiana Huber) através de estaquia. SILVICULTURA, v.8, n.41, p.68. 1986. Apresentado ao 5. Congresso Florestal Brasileiro, Recife, 1986 - Anais.

VENKOVSKY, R. Amostragem genética em populações naturais. SILVICULTURA, v.8, n.41, p.95, 1986. Apresentado ao 5. Congresso Florestal Brasileiro, Recife, 1986 - Anais.

\section{7: 3 trabalhos}

KAGEYAMA, P.Y. Conservação "In Situ" de Recursos Genéticos de Plantas. IPEF, v.35, p.7-40, abril 1987.

MARTINS, P.S. Estrutura Populacional, Fluxo Gênico e Conservação "In Situ". IPEF, v.35, p.71-78, abril 1987. 
VENCOVSKY, R. Tamanho Efetivo Populacional na Coleta e Preservação e Germoplasma de Espécies Alógamas. IPEF, v.35, p.79-84, abril 1987.

1989: 1 trabalho

KAGEYAMA, P.Y.; CASTRO, C.F.A. Sucessão secundária, estrutura genética e plantaç̃es de espécies arbóreas nativas. IPEF, v.41/42, p. 83, 1989.

1990: 1 trabalho

BOVI, M.L.A.; SPIERING, S.H.; CAMARGO, S.B.de; GODOY JÚNIOR, G. Correlações fenotípicas entre caracteres avaliados nos estádios juvenil e adulto de açaizeiros. In: CONGRESSO FLORESTAL BRASILEIRO, 6., Campos do Jordão, 1990. Anais. Campos do Jondão: SBS/SBEF, 1990. v.3, p.635-640.

1992: 5 trabalhos

HIGA, A.R; RESENDE, M.D.V.; CARVALHO, P.E.R. Pomar de sementes por mudas: um método para conservação genética "ex-situ" de Araucaria angustifolia (Bert.) O.Ktze. Revista do Instituto Florestal, v.4, parte 4, p.1217-1224, 1992. Edição Especial. Apresentado ao 2. Congresso Nacional sobre Essências Nativas, São Paulo, 1992 - Anais.

KANASHIRO, M. Genética e melhoramento de essências florestais nativas: aspectos conceituais e práticos. Revista do Instituto Florestal. v.4, parte 4, p.1168-1178, 1992. Edição Especial. Apresentado ao 2. Congresso Nacional sobre Essências Nativas, São Paulo, 1992 - Anais.

LLERAS, E. Conservação de recursos genéticos florestais. Revista do Instituto Florestal, v.4, parte 4, p.1179. 1184, 1992. Edição Especial. Apresentado ao 2. Congresso Nacional sobre Essências Nativas, São Paulo, 1992 - Anais.

OHASH, T.; KAGEYAMA, P.Y; COSTA, L.G.S. Variação genética entre populações de Euterpe oleraceae Martl do estuário amazônico. Revista do Instituto Florestal, v.4, parte 4, p.1246-1251, 1992. Edição Especial. Apresentado ao 2. Congresso Nacional sobre Essências Nativas, São Paulo, 1992 - Anais.

REIS, M.S.dos; FRANCHINI, R.G.; REIS, A.; FANTINI, A.C. Variação no periodo germinativo em sementes de Euterpe edulius Martius procedentes da região de Morretes -PR. Revista do Instituto Florestal, v.4, parte 4, p.1252-1256, 1992. Edị̧̃̃o Especial. Apresentado ao 2. Congresso Nacional sobre Essências Nativas. São Paulo, 1992 - Anais.

\section{3: 2 trabalhos}

GANDARA, F.B. Enxertia em Cedrela fissilis vell (meliaceae): utilização para conservação e estudos de variabilidade genética. In: CONGRESSO FLORESTAL BRASILEIRO, 7., Curitiba, 1993. Anais. Curitiba: SBS/SBEF, 1993. v.2, p.427-428.

RESENDE, M.D.V.; ARAUJO, A.J. Modelo genético-estatístico para estimação de componentes da variação genética e parâmetros genéticos em testes de progênies com individuos repetidos clonalmente. FLORESTA, v.23, n.1/2, p.35-46, jun./dez. 1993.

\section{4: 1 trabalho}

RESENDE, M.D.V. Correlação interclasse entre valores genéticos e implicações na comparação de métodos de seleção. FLORESTA. v.24, n.1/2, p.37-48, jun./dez. 1994.

\section{4) Manejo}

\section{1) Teste em Solos}

\section{4: 1 trabalho}

RICHTER, H.G.; TOMASELLI, I.; MORESCHI, J.C. Estudo tecnológico do guapuruvu (Schizolobium parahybum). 1a PARTE: Informações Gerais. FLORESTA, v.5, n.1, p.26-30, julho 1974. 
1978: 1 trabalho

HOOGH, RJ. de; DIETRICH, A.B. Relação Crescimento-Sítio de Araucaria angustifolia (Bert.) O. Ktze em Povoamentos Plantados. Silvicultura, v.2, n.14, p.34-40, 1978. Edição Especial. Apresentado ao 3. CONGRESSO FLORESTAL BRASILEIRO, Manaus, 1978 - Anais

1982: 2 trabalhos

BATISTA, M.P.; BORGES, J.F; BRANCO, M.A.B. Avaliação do crescimento inicial de uma essência nativa em comparação com outras exóticas, no Nordeste do Pará, Brasil. SILVICULTURA EM SÃO PAULO, v.16A, parte2, p.1105-1110, 1982. Edição Especial. Apresentado ao Congresso Nacional sobre Essências Nativas, Campos do Jordão, 1982 - Anais.

NOGUEIRA, J.C.B.; SIQUEIRA, A.C.M.F.; GARRIDO, M.A.O. et al. Ensaio de competição de algumas essências nativas em diferentes regiões do Estado de São Paulo. SILVICULTURA EM SÃO PAULO, v.16A, parte2, p.1051-1053, 1982. Edição Especial. Apresentado ao Congresso Nacional sobre Essências Nativas, Campos do Jordão, 1982 - Anais.

\section{2) Consorciação}

1953: 1 trabalho

VASCONCELLOS, P.W.C. Saguaragi - Colubrina rufa, Reiss. familia Rhamnaceae 1) Consorciação com Eucaliptus tereticomis, Eucaliptus rostrata. In: CONGRESSO FLORESTAL BRASILEIRO,1., Curitiba, 1953. Anais. Curitiba: Instituto Nacional do Pinho, 1953. p.195-199.

\section{4: 1 trabalho}

RICHTER, H.G.; TOMASELLI, I.; MORESCHI, J.C. Estudo tecnológico do guapuruvu (Schizolobium parahybum). 1ª PARTE: Informações Gerais. FLORESTA. v.5, n. 1, p. 26-30, julho 1974.

1982: 6 trabalhos

GUIDONI, B.A.; KONECSNI, I. Reflorestamento de Araucaria angustifolia (Bertolini) O.Kuntze na Companhia Melhoramentos de São Paulo - Indústria de Papel Caieiras. SLLVICULTURA EM SÃO PAULO, v.16A, parte2, p.732-746, 1982. Edição Especial. Apresentado ao Congresso Nacional sobre Essências Nativas, Campos do Jordão, 1982 - Anais.

MARIANO, G.; GIANNOTTI, E; TIMONI, J.L.; VEIGA. A.A. Reconstituição de floresta de essências indígenas. SHLVICULTURA EM SÃO PAULO, v.16A, parte2, p.1086-1091, 1982. Edição Especial. Apresentado ao Congresso Nacional sobre Essências Nativas. Campos do Jordão, 1982 - Anais.

MORAES, J.L.de; COELHO, L.C.C. Diversos compassos em guapuruví. SILVICULTURA EM SÃO PAULO, v.16A, parte2, p.1153-1155. 1982. Edição Especial. Apresentado ao Congresso Nacional sobre Essências Nativas, Campos do Jordão, 1982 - Anais.

PINHEIRO, G.S.; VEIGA, A.A.; MARIANO, G. Estudo do comportamento do pau-jacaré e guarantã sob povoamento misto. SILVICULTURA EM SÃO PAULO, v. 16A, parte2, p.1032-1035, 1982. Edição Especial. Apresentado ao Congresso Nacional sobre Essências Nativas. Campos do Jordão, 1982 - Anais.

TOLEDO FILHO, D.V.de; PARENTE, P.R. Essências indígenas sombreadas. SILVICULTURA EM SÃO PAULO, v.16A, parte2, p.948-956, 1982. Edição Especial. Apresentado ao Congresso Nacional sobre Essências Nativas, Campos do Jordão, 1982 - Anais.

VILA, W.M.; TEIXEIRA, E.P.; GARRIDO. M.A.O. et al. Ocorrência de Hypsipyla sp (Lepidoptera: Pyralidae) em ensaios de consorciação de Meliaceae. SILVICULTURA EM SÃO PAULO, v. 16A, parte2, p.1209. 1218, 1982. Edição Especial. Apresentado ao Congresso Nacional sobre Essências Nativas, Campos do Jordão, 1982 - Anais.

1983: 3 trabalhos 
BRIENZA JÚNIOR, S. Cordia Goeldiana HUBER (Freijó) em Sistema "Taungya" na Amazônia Brasileira. SILVICULTURA, n.28, p.206-208, 1983. Apresentado ao 4. Congresso Florestal Brasileiro, Belo Horizonte, 1982 - Anais.

GARRIDO, M.A.O.; SOUZA, A.C.de Manejo Cientifico de Povoamentos Florestais de Espécies Indígenas. SILVICULTURA, 11.28, p.60-63, 1983. Apresentado ao 4. Congresso Florestal Brasileiro, Belo Horizonte, 1982 - Anais.

TIMONI, J.L.; MARIANO, G.; GIANOTTI, E.; VEIGA, A.A. Consociação de Essências Florestais em Tupi. SILVICULTURA, n.28, p.530, 1983. Apresentado ao 4. Congresso Florestal Brasileiro, Belo Horizonte, 1982 - Anais.

1986: 3 trabalhos

BOVI, M.L.A.; SAES, L.A.; CARDOSO, M.; CIONE, J. Densidade de plantio de palmiteiro (Euterpe edulis Mart.) em regime de sombreamento definitivo. SILVICULTURA, v.11, n.41, p.71, 1986. Apresentado ao 5. Congresso Florestal Brasileiro, Recife, 1986 - Anais.

NODARI, R.O.; GUERRA, M.P.; REIS. A. Resposta de mudas de Colubrina glandulosa Perkins var. Reitzii (M.C. Johnston) M.C. Johnston, a diferentes composições de substrato - fase de viveiro. SILVICULTURA, v.11, n.41, p.75, 1986. Apresentado ao 5. Congresso Florestal Brasileiro, Recife, 1986 - Anais

YAMAZOE, G.; MOURA NETTO, B.V.de; DIAS, A.C. Comportamento de Euterpe oleracea Mart. nas condições edafo-climáticas de Sete Barras (SP). SILVICULTURA, v.11, n.41, p.67, 1986. Apresentado ao 5. Congresso Florestal Brasileiro, Recife, 1986 - Anais.

1989: 1 trabalho

KAGEYAMA. P.Y.; CASTRO, C.F.A. Sucessão secundária, estrutura genética e plantações de espécies arbóreas nativas. IPEF, v.41/42, p. 83, 1989.

\section{0: 6 trabalhos}

CARPANEZZI, A.A.; COSTA, L.G.S.; KAGEYAMA, P.Y.; CASTRO, C.F.A. Espécies pioneiras para recuperação de áreas degradadas: a observação de laboratórios naturais. In: CONGRESSO FLORESTAL BRASILEIRO, 6., Campos do Jordão, 1990. Anais. Campos do Jordão: SBS/SBEF, 1990. v.3, p.216-220.

GARRIDO, M.A.O.; DOMINGOS, P.R.; GARRIDO, L.M.A.G.; DURIGAN, G. Pesquisa e experimentação com cinco espécies nativas. In: CONGRESSO FLORESTAL BRASILEIRO, 6., Campos do Jordão, 1990. Anais. Campos do Jordão: SBS/SBEF, 1990. v.3, p.602-609.

MARTINS, S.S.; TAKAHASHI, L.Y.; BORGES, R.C.G. Desenvolvimento de algumas espécies florestais nativas em plantio de enriquecimento. In: CONGRESSO FLORESTAL BRASILEIRO, 6., Campos do Jordão, 1990. Anais. Campos do Jordão: SBS/SBEF, 1990. v.3, p.239-242.

SANTARELLI, E.G. Comportamento de algumas espécies vegetais na recomposição de matas nativas. In: CONGRESSO FLORESTAL BRASILEIRO, 6., Campos do Jordão, 1990. Anais. Campos do Jordão: SBS/SBEF, 1990. v.3, p.232-235.

VIEIRA, J.D.; DINIZ, A.S.; DÁRIO, F.R. Recomposição com essências nativas de cerrado. In: CONGRESSO FLORESTAL BRASILEIRO, 6., Campos do Jordão, 1990. Anais. Campos do Jordão: SBS/SBEF, 1990. v.3, p.226-231.

YAMAZOE, G.; DIAS, A.C.; MOURA NETTO, B.V.de Comportamento de Euterpe edulis Mart. Sob Pinus pinaster Ailton em diferentes intensidades de desbaste. In: CONGRESSO FLORESTAL BRASILEIRO, 6 ., Campos do Jordão, 1990. Anais. Campos do Jordão: SBS/SBEF, 1990. v.3, p.610-612.

1992: 4 trabalhos 
AOKI, H.; SOUZA, W.J.M.de Comportamento do jatobá (Hymenaea courbaril var. stilbocarpa) consorciado com Pinus elliottii var. elliottii em condições de arboreto. Revista do Instituto Florestal, v.4, parte 2, p.504-505, 1992. Edição Especial. Apresentado ao 2. Congresso Nacional sobre Essências Nativas, São Paulo, 1992 - Anais.

BARBOSA, L.M.; ASPERTI, L.M.; BEDINELLI, C. et al. Estudos sobre o estabelecimento e desenvolvimento de espécies com ampla ocorrência em mata ciliar. Revista do Instituto Florestal, v.4, parte 2, p.605-608, 1992. Edição Especial. Apresentado ao 2. Congresso Nacional sobre Essências Nativas, São Paulo, 1992 Anais.

JESUS, R.M.de; GARCIA, A. Sistemas agroflorestais: um modelo para o norte do Espírito Santo. Revista do Instituto Florestal, v.4, parte 3, p.714-718, 1992. Edição Especial. Apresentado ao 2. Congresso Nacional sobre Essências Nativas, São Paulo, 1992 - Anais.

KAGEYAMA, P.Y.; FREIXÊDAS, V.M.; GERES, L.A. et al. Consórcio de espécies nativas de diferentes grupos sucessionais em Teodoro Sampaio - SP. Revista do Instituto Florestal, v.4, parte 2, p.527-533, 1992. Edição Especial. Apresentado ao 2. Congresso Nacional sobre Essências Nativas, São Paulo, 1992 Anais.

\section{3: 5 trabalhos}

DAVIDE, A.C.; SCOLFORO, J.R.S.; PRADO, N.J.S.: FARIA, J.M.R. Comportamento de seis espécies florestais em áreas de depleção da Usina Hidrelétrica de Camargos - MG. In: CONGRESSO FLORESTAL BRASILEIRO, 7., Curitiba, 1993. Anais. Curitiba: SBS/SBEF, 1993. v.2, p.412-415.

MORAES, M.L.T.de; CAMBUIM, J.; KAGEYAMA, P.Y. Variabilidade genética em duas populações naturais de aroeira (Mtracrodruon urundeuva fr. all.) consorciada com candiúba (Trema micrantha (1.) blum). In: CONGRESSO FLORESTAL BRASILEIRO, 7., Curitiba, 1993. Anais. Curitiba: SBS/SBEF, 1993. v.2, p.767-768.

POGGIANI, F.; SIMÕES, J.W. Influência da espécies usadas no reflorestamento e da proximidade de um fragmento florestal na regeneração do sub-bosque em áreas degradadas pela mineração. In: CONGRESSO FLORESTAL BRASILEIRO, 7., Curitiba, 1993. Anais. Curitiba: SBS/SBEF, 1993. v.1, p.50-53.

SILVA, L.B.X.da; TORRES, M.A.V. Reflorestamento misto x puro - Foz do Chopim (1979 - 1991) Copel Paraná. In: CONGRESSO FLORESTAL BRASILEIRO, 7., Curitiba, 1993. Anais. Curitiba: SBS/SBEF, 1993. v.2, p.463-466.

VALERI, S.V; DEMATTÊ, M.E.S.P.; AGUIAR, I.B.de et al. Influência de leguminosas no desenvolvimento de Genipa americana l. e Inga spp, consorciadas com Cecropia spp e Croton urucurana baill - sob dois espaçamentos. In: CONGRESSO FLORESTAL BRASILEIRO, 7., Curitiba, 1993. Anais. Curitiba: SBS/SBEF, 1993. v.2, p.438-442.

\section{3) Espaçamento}

\section{3: 1 trabalho}

KOHUT, R. Algumas observações sobre as plantações de Araucaria angustifolia nos campos paranaenses. In: CONGRESSO FLORESTAL BRASILEIRO, 1., Curitiba, 1953. Anais. Curitiba: Instituto Nacional do Pinho, 1953. p.137-142.

\section{2: 1 trabalho}

JANKAUSKIS, J. Ensaio de Plantio de Araucaria angustifolia (Bert) O'Ktze. FLORESTA, v.4, n. 1, p.54-62, dezembro 1972.

1978: 1 trabalho 
GURGEL FILHO, O.A.; GARRIDO, L.M.A.G.; NETTO, S.M.R. Caracteres Silviculturais e Biométricos do Crescimento de Algumas Essências Nativas da Zona Temperada (1). Silvicultura, v.2, n. 14, p.60-81, 1978. Edição Especial. Apresentado ao 3. CONGRESSO FLORESTAL BRASILEIRO, Manaus, 1978 - Anais.

\section{2: 18 trabalhos}

COELHO, L.C.C.; NOGUEIRA, J.C.B.; SIQUEIRA, A.C.M.F. et al. Ensaio de espaçamento de ibirá-puitá Peltophorum dubium (Spreng) Taub., frente às condições de Mogi Guaçu -S.P. SILVICULTURA EM SÃO PAULO, v.16A, parte2, p.1036-1038, 1982. Edição Especial. Apresentado ao Congresso Nacional sobre Essências Nativas, Campos do Jordão, 1982 - Anais.

GARRIDO, M.A.O;; NOGUEIRA, J.C.B.; GARRIDO, L.M.A.G. Características silviculturais do pau-marfim - Balfourodendron riedelianum Engl. SILVICULTURA EM SÃO PAULO, v.16A, parte2, p.1081-1085, 1982. Edição Especial. Apresentado ao Congresso Nacional sobre Essências Nativas, Campos do Jordão, 1982 - Anais.

GUIDONI, B.A.; KONECSNI, I. Reflorestamento de Araucaria angustifolia (Bertolini) O.Kuntze na Companhia Melhoramentos de São Paulo - Indústria de Papel Caieiras. SILVICULTURA EM SÃO PAULO, v.16A, parte2, p.732-746, 1982. Edição Especial. Apresentado ao Congresso Nacional sobre Essências Nativas, Campos do Jordão, 1982 - Anais.

GURGEL FILHO, O.A.; MORAES, J.L.; GARRIDO, L.M.A.G. Silvicultura de essências indígenas sob povoamentos homóclitos coetâneos experimentais. I - araribá-amarelo (Centrolobium tomentosum Benth.). SILVICULTURA EM SÃO PAULO, v.16A, parte2, p.841-846, 1982. Edição Especial. Apresentado ao Congresso Nacional sobre Essências Nativas, Campos do Jordão, 1982 - Anais.

GURGEL FILHO, O.A.; MORAES, J.L.; GARRIDO, L.M.A.G. Silvicultura de essências indígenas sob povoamentos homóclitos coetâneos experimentais. II - guarantã (Esenbeckia leiocarpa Eng.). SILVICULTURA EM SÃ O PAULO, v.16A, parte2, p.847-851, 1982. Edição Especial. Apresentado ao Congresso Nacional sobre Essências Nativas, Campos do Jordão, 1982 - Anais.

GURGEL FILHO, O.A.; MORAES, J.L.; GARRIDO, L.M.A.G. Silvicultura de essências indígenas sob povoamentos homóclitos coetâneos experimentais. III - ibirá (Peltophorum vogelianum Benth.) SILVICULTURA EM SÃ O PAULO. v.16A, parte2, p.852-856, 1982. Edição Especial. Apresentado ao Congresso Nacional sobre Essências Nativas, Campos do Jordão, 1982 - Anais.

GURGEL FILHO, O.A.; MORAES, J.L.; GARRDO, L.M.A.G. Silvicultura de essências indígenas sob povoamentos homóclitos coetâneos experimentais. IV - jatobá (Hymenaea stilbocarpa Hayne).

SILVICULTURA EM SÃO PAULO. v.16A, parte2, p.857-861, 1982. Edição Especial. Apresentado ao Congresso Nacional sobre Essências Nativas, Campos do Jordão, 1982 - Anais.

GURGEL FILHO, O.A.; MORAES, J.L.; GARRIDO, L.M.A.G. Silvicultura de essências indígenas sob povoamentos homóclitos coetâneos experimentais. V - pau-ferro (Caesalpina leiostachya (Benth.) Ducke). SILVICULTURA EM SÃo PAULO, v.16A, parte2, p.862-866, 1982. Edição Especial. Apresentado ao Congresso Nacional sobre Essências Nativas, Campos do Jordão, 1982 - Anais.

GURGEL FILHO, O.A.; MORAES, J.L.; GARRIDO, L.M.A.G. Silvicultura de essências indígenas sob povoamentos homóclitos coetâneos experimentais. VI - pau-marfim (Balflurodendron riedeleanum Eng.). SILVICULTURA EM SÃO PAULO. v.16A, parte2, p.867-871, 1982. Edição Especial. Apresentado ao Congresso Nacional sobre Essências Nativas, Campos do Jordão, 1982 - Anais.

GURGEL FILHO, O.A.; MORAES, J.L.; GARRIDO, L.M.A.G. Silvicultura de essências indígenas sob povoamentos homóclitos coetâneos experimentais. VII - pau-pereira (Platycyamus regnellii Benth.). SILVICULTURA EM SÃo PAULO. v.16A, parte2, p.872-877, 1982. Edição Especial. Apresentado ao Congresso Nacional sobre Essências Nativas, Campos do Jordão, 1982 - Anais. 
GURGEL FILHO, O.A.; MORAES, J.L.; GARRIDO. L.M.A.G. Silvicultura de essências indígenas sob povoamentos homóclitos coetâneos experimentais. VIII - peroba-rosa (Aspidosperma polvneuron M.Arg.). SILVICULTURA EM SÃO PAULO. v. 16A, parte2, p.878-883, 1982. Edição Especial. Apresentado ao Congresso Nacional sobre Essências Nativas, Campos do Jordão, 1982 - Anais.

GURGEL FILHO, O.A.; MORAES, J.L.; GARRIDO, L.M.A.G. Silvicultura de essências indigenas sob povoamentos homóclitos coetâneos experimentais. IX - pinheiro-brasileiro (Araucaria angustifolia (Bert.) O.Ktze.). SILVICULTURA EM SÃO PAULO, v.16A, parte2, p., 1982. Edição Especial. Apresentado ao Congresso Nacional sobre Essências Nativas, Campos do Jordão, 1982 - Anais.

MENDES, C.J.; REZENDE, G.C.de; SUITER FILHO, W.; MORAES, T.S.A. Considerações sobre o potencial silvicultural e energético de quatro espécies nativas. SILVICULTURA EM SÃO PAULO, v.16A, parte2, p.1350-1359, 1982. Edição Especial. Apresentado ao Congresso Nacional sobre Essências Nativas, Campos do Jordão, 1982 - Anais.

NOGUEIRA, J.C.B.; SIQUEIRA, A.C.M.F.; BERTOLDI, S.E. Ensaio de espaçamento do araribá-amarelo Centrolobium tomentosum Guill, frente às condições de Pederneiras - SP. SILVICULTURA EM SÃO PAULO, v.16A, parte2, p.1039-1042, 1982. Edição Especial. Apresentado ao Congresso Nacional sobre Essências Nativas, Campos do Jordão, 1982 - Anais.

NOGUEIRA, J.C.B.; SIQUEIRA, A.C.M.F.; MORAIS, E.; ZANDARIN, M.A. Plantio da cabreúva - Miroxvlon peruiferum L.F. em diferentes espaçamentos. SILVICULTURA EM SÃO PAULO, v. 16A, parte2.p. 10641069, 1982. Edição Especial. Apresentado ao Congresso Nacional sobre Essências Nativas, Campos do Jordão, 1982 - Anais.

ROSA, P.R.F.da; NOGUEIRA, J.C.B.; SIQUEIRA, A.C.M.F.; SALLES, L.M.A.B. Caracteres silviculturais do ipê-amarelo Tabebuia vellosoi. SILVICULTURA EM SÃO PAULO, v.16A, parte2, p. 1070-1075, 1982. Edição Especial. Apresentado ao Congresso Nacional sobre Essências Nativas, Campos do Jordão, 1982 Anais.

SOUZA, W.J.M.de; NOGUERA, J.C.B.; SIQUEIRA, A.C.M.F. et al. Ensaio de espaçamento de canela-imbuia - Ocotea porosa (Ness) L.Barroso, em Angatuba - SP. SILVICULTURA EM SÃo PAULO, v.16A, parte2, p.1043-1046, 1982. Edição Especial. Apresentado ao Congresso Nacional sobre Essências Nativas, Campos do Jordão, 1982 - Anais.

ZANATTO, A.C.S.; NOGUEIRA. J.C.B.: SIQUEIRA. A.C.M.F.; BERTOLDI, S.E. Ensaio de espaçamentos de jequitibá-vermelho - Cariniana legalis (Mart.) O.Ktze. frente às condições de Luiz Antônio - São Paulo. SILVICULTURA EM SÃO PAULO, v.16A, parte2,p.1047-1050, 1982. Edição Especial. Apresentado ao Congresso Nacional sobre Essências Nativas, Campos do Jordão, 1982 - Anais.

\section{3: 2 trabalhos}

AGUIAR, I.B.; ALOI, S.V.; TAVARES, L.C.V.; MINEHIRA, T. Efeitos do Espaçamento no Comportamento Silvicultural de Coumarouna alata (VOG.) TAUB. SILVICULTURA, n.28, p. 126-128, 1983. Apresentado ao 4. Congresso Florestal Brasileiro, Belo Horizonte, 1982 - Anais.

CARVALHO, P.E.R. Ensaio de Espaçamento para o Louro-pardo (Cordia trichotoma 'VELL' ARRAB. EX STEUD). Resultados Preliminares. SILVICULTURA, n.28, p.267-268, 1983. Apresentado ao 4. Congresso Florestal Brasileiro, Belo Horizonte, 1982 - Anais.

\section{6: 2 trabalhos}

BOVI, M.L.A.; SAES, L.A.; CARDOSO, M.; CIONE, J. Densidade de plantio de palmiteiro (Euterpe edulis Mart.) em regime de sombreamento definitivo. SILVICULTURA. v.11, n.41, p.71, 1986. Apresentado ao 5. Congresso Florestal Brasileiro, Recife, 1986 - Anais. 
ZANATTO, A.C.S.; SIQUEIRA, A.C.M.F.; NOGUEIRA, J.C.B.; CRUZ, I.I.da Caracteres silviculturais do Jequitibá Vermelho. SILVICULTURA. v.11, n.41, p.64, 1986. Apresentado ao 5. Congresso Florestal Brasileiro, Recife, 1986 - Anais.

\section{0: 2 trabalhos}

BARBOSA, A.P. O crescimento de mudas de caroba (Jacaranda copaia Aubl. D. Don - Bignoniaceae) cultivadas sob diferentes níveis de sombreamento e espaçamento. In: CONGRESSO FLORESTAL BRASILEIRO, 6., Campos do Jondão, 1990. Anais. Campos do Jordão: SBS/SBEF, 1990. v.3, p.526-534.

FONSECA, C.E.L.da; BUENO, D.M.; SPERÂNDIO, J.P. Comportamento do Jacarandá-da-baía aos cinco anos de idade em quatro diferentes espaçamentos em Manaus-AM. ÁRVORE, v.14, n.2, p.78-84, jul./dez. 1990.

1992: 3 trabalhos

AGUIAR, I.B.de; VALERI, S.V.; ISMAEL, J.J.; ALHO, D.R. Efeitos do espaçamento no desenvolvimento de Dipteryx alata (Vog.) Taub. em Jaboticabal - SP até a idade de 20 anos. Revista do Instituto Florestal, v.4, parte 2, p.570-572, 1992. Edição Especial. Apresentado ao 2. Congresso Nacional sobre Essências Nativas, São Paulo, 1992 - Anais.

JESUS, R.M.de; GARCIA, A. Teste de espaçamento com Zeyehera tuberculosa (Vell.) Bur. - crescimento aos 48 meses de idade. Revista do Instituto Florestal. v.4, parte 3, p.719-724, 1992. Edição Especial. Apresentado ao 2. Congresso Nacional sobre Essências Nativas, São Paulo, 1992 - Anais.

JESUS, R.M.de; GARCIA, A.; TSUTSUMI. I. Comportamento de doze espécies florestais da Mata Atlântica em povoamentos puros. Revista do Instituto Florestal, v.4, parte 2, p.491-496, 1992. Edição Especial. Apresentado ao 2. Congresso Nacional sobre Essências Nativas, São Paulo, 1992 - Anais.

1993: 3 trabalhos

GARCIA, S.L.R.; LEITE, H.G.; YARED, J.A.G. Análise do perfil do tronco de morototó (Didymopamax morototoni) em função do espaçamento. In: CONGRESSO FLORESTAL BRASILEIRO, 7., Curitiba, 1993. Anais. Curitiba: SBS/SBEF, 1993. v.1, p.223-224.

VALERI, S.V.; DEMATTÊ, M.E.S.P.; AGUIAR, I.B.de et al. Influência de leguminosas no desenvolvimento de Genipa americana l. e Inga spp, consorciadas com Cecropia spp e Croton urucurana baill - sob dois espaçamentos. In: CONGRESSO FLORESTAL BRASILEIRO, 7., Curitiba, 1993. Anais. Curitiba: SBS/SBEF, 1993. v.2, p.438-442.

YARED, J.A.G.; LEITE, H.G.; SILVA, R.R.F.da Volumetria e fator de forma de morototó (Didymopamax morototonii Aubl. Decne et Planch) sob diferentes espaçamentos. In: CONGRESSO FLORESTAL BRASILEIRO, 7., Curitiba, 1993. Anais. Curitiba: SBS/SBEF, 1993. v.2, p.570-573.

\section{4) Desbaste}

\section{3: 2 trabalhos}

KOHUT, R. Algumas observações sobre as plantações de Araucaria angustifolia nos campos paranaenses. In: CONGRESSO FLORESTAL BRASILEIRO, 1., Curitiba, 1953. Anais. Curitiba: Instituto Nacional do Pinho, 1953. p.137-142.

NOWACKI, M.J. A bracatinga e os fungos apodrecedores da sua madeira. In: CONGRESSO FLORESTAL BRASILEIRO, 1., Curitiba, 1953. Anais. Curitiba: Instituto Nacional do Pinho, 1953. p.91-94.

1970: 2 trabalhos

MACEDO, J.H.P. Palmito - Uma Grande Fonte de Divisas. FLORESTA, v.2, n.3, p.19-20, dezembro 1970.

SOARES, R.V. Desbaste em Araucaria angustifolia (BERT.) O'Ktze. FLORESTA, v.2, n.3, p.59-68, dezembro 1970. 
1971: 1 trabalho

HOSOKAWA, R.T.; KAJIVA, S. Ensaio da Aplicabilidade da Fórmula Franco-Inglesa como Modelo Matemático para a Volumetria dos Produtos de Desbaste da Araucaria angustifolia para a Indústria Papeleira. FLORESTA, v.3, n.2, p.75-82, novembro 1971.

1973: 1 trabalho

CARNEIRO, J.G.A. Desbastes Florestais. FLORESTA, v.4, n.3, p.45-56, dezembro 1973.

1975: 1 trabalho

VEIGA, R.A.A.;VEIGA, A.A. Relações entre porcentagem de extração e taxa de acréscimo diametral em desbastes florestais. FLORESTA. v.6, n.1, p.31-35, junho 1975.

1978: 1 trabalho

GURGEL FILHO, O.A.; GARRIDO, L.M.A.G.; NETTO, S.M.R. Caracteres Silviculturais e Biométricos do Crescimento de Algumas Essências Nativas da Zona Temperada (1). Silvicultura, v.2, n.14, p.60-81, 1978. Edição Especial. Apresentado ao 3. CONGRESSO FLORESTAL BRASILEIRO, Manaus, 1978 - Anais.

1982: 1 trabalho

GUIDONI, B.A.; KONECSNI, I. Reflorestamento de Araucaria angustifolia (Bertolini) OKuntze na Companhia Melhoramentos de São Paulo - Indústria de Papel Caieiras. SILVICULTURA EM SÃo PAULO, v.16A, parte2, p.732-746, 1982. Edição Especial. Apresentado ao Congresso Nacional sobre Essências Nativas, Campos do Jordão, 1982 - Anais.

1983: 1 trabalho

PINTO, S.A.A. Influência da Dioicia no Diâmetro e na Altura de Araucaria angustifolia (BERT.) O.KTZE. e suas Implicações na Formação de Áreas de Produção de Sementes na Região de Quedas do Iguaçu - Estado do Paraná. SILVICULTURA, n.28, p.433-436, 1983. Apresentado ao 4. Congresso Florestal Brasileiro, Belo Horizonte, 1982 - Anais.

1986: 2 trabalhos

MOURA NETTO, B.V.de; DIAS, A.C.; YAMAZOE, G. Sobrevivência de Euterpe edulis em Plantio sob Diferentes Tipos de Vegetação. SILVICULTURA, v.11, n.41, p.64, 1986. Apresentado ao 5. Congresso Florestal Brasileiro, Recife, 1986 - Anais.

YAMAZOE, G.; DIAS, A.C.; MOURA NETTO, B.V.de Comportamento de Euterpe oleracea Mart ns condições edafo-climáticas de Sete Barras (SP). SILVICULTURA, v.11, n.41, p.67, 1986. Apresentado ao 5. Congresso Florestal Brasileiro, Recife, 1986 - Anais.

1990: 1 trabalho

GARRIDO, M.A.O.; DOMINGOS, P.R.; GARRIDO, L.M.A.G.; DURIGAN, G. Pesquisa e experimentação com cinco espécies nativas. In: CONGRESSO FLORESTAL BRASILEIRO, 6., Campos do Jordão, 1990. Anais. Campos do Jordão: SBS/SBEF, 1990. v.3, p.602-609.

1992: 1 trabalho

HIGA, A.R.; RESENDE, M.D.V.; CARVALHO, P.E.R. Pomar de sementes por mudas: um método para conservação genética "ex-situ" de Araucaria angustifolia (Bert.) O.Ktze. Revista do Instituto Florestal, v.4, parte 4, p.1217-1224, 1992. Edição Especial. Apresentado ao 2. Congresso Nacional sobre Essências Nativas, São Paulo, 1992 - Anais.

1993: 1 trabalho 
SCOLFORO, J.R.S. Simulaçào de desbastes seletivos através de modelo matemático. In: CONGRESSO FLORESTAL BRASILEIRO, 7., Curitiba, 1993. Anais. Curitiba: SBS/SBEF, 1993. v.2, p.549-552.

\section{5) Outros}

\section{3: 3 trabalhos}

KOHUT, R. Algumas observações sobre as plantações de Araucaria angustifolia nos campos paranaenses. In: CONGRESSO FLORESTAL BRASILEIRO, 1., Curitiba, 1953. Anais. Curitiba: Instituto Nacional do Pinho, 1953. p.137-142.

NOWACKI, M.J. A bracatinga e os fungos apodrecedores da sua madeira. In: CONGRESSO FLORESTAL BRASILEIRO, 1., Curitiba, 1953. Anais. Curitiba: Instituto Nacional do Pinho, 1953. p.91-94.

VASCONCELLOS. P.W.C. Saguaragi - Colubrina rufa, Reiss. familia Rhamnaceae 1) Consorciação com Eucaliptus tereticornis, Eucaliptus rostrata. In: CONGRESSO FLORESTAL BRASILEIRO, 1., Curitiba, 1953. Anais. Curitiba: Instituto Nacional do Pinho, 1953. p.195-199.

1969: 1 trabalho

BRANDÃO, A.E. O Sobreiro. FLORESTA, v.1, n.1, p.67-68, junho 1969.

1970: 1 trabalho

MACEDO, J.H.P. Palmito - Uma Grande Fonte de Divisas. FLORESTA, v.2, n.3, p.19-20, dezembro 1970. 1971: 1 trabalho

MACEDO, J.H.P. Palmito - Uma Grande Fonte de Divisas (II). FLORESTA, v.3, n.1, p.29-34, maio 1971. 1972: 1 trabalho

JANKAUSKIS, J. Ensaio de Plantio de Araucaria angustifolia (Bert.) O'Ktze. FLORESTA, v.4, n.1, p.54-62, dezembro 1972.

\section{3: 5 trabalhos}

INOUE, M.T. Ensaio de Procedência de Cedrela em Santo Antônio da Platina - PR. FLORESTA, v.4, n.2, p.49-57, setembro 1973.

JANKAUSKIS, J. Semeadura direta de Araucaria angustifolia (Bert.) O'Ktze. In: CONGRESSO FLORESTAL BRASILEIRO, 2.,Curitiba, 1973. Anais. Curitiba: 1973. p.77-78.

LEMOS, J.M. Reflorestamento com Virola surinamensis (Ucuúba da várzea) na Ilha do Marajó. In: CONGRESSO FLORESTAL BRASILEIRO, 2.,Curitiba, 1973. Anais. Curitiba: 1973. p.109-111.

MACEDO, J.H.P. Manejo Sustentado do Palmito. FLORESTA, v.4, n.3, p.57-59, dezembro 1973.

SCHIMIDLIN, D. A importância da poda na qualidade da madeira. In: CONGRESSO FLORESTAL BRASILEIRO, 2.,Curitiba, 1973. Anais. Curitiba: 1973. p.186-187.

\section{7: 2 trabalhos}

INOUE, M.T. A auto-ecologia do gênero Cedrela: efeitos na fisiologia do crescimento no estágio juvenil em função da intensidade luminosa. FLORESTA, v.8, n.2, p. 89-92, dezembro 1977.

SEITZ, R.A. Algumas características ecológicas e silviculturais do vassourão branco (Piptocarpha angustifolia Dusén). FLORESTA, v.8, n.1, p. 89-92, junho 1977.

1978: 2 trabalhos 
CARVALHO, P.E.R.; STÖHR, G.W.D. Regeneração Artificial com Essências Nativas no Paraná. Silvicultura, v.2, n. 14, p.82-84, 1978. Edição Especial. Apresentado ao 3. CONGRESSO FLORESTAL BRASILEIRO, Manaus, 1978 - Anais.

INOUE, M.T.; GALVÃO,F,; TORRES.D. A Produção Primária de Araucaria angustifolia (Bert.) O.Ktze. No Estágio de Muda em Dependência da Intensidade Luminosa. Silvicultura, v.2, n.14, p.34-40, 1978. Edição Especial. Apresentado ao 3. CONGRESSO FLORESTAL BRASILEIRO, Manaus, 1978 - Anais.

1979: 2 trabalhos

INOUE, M.T.; GALVÃO, F.; TORRES, D.V. Estudo ecofisiológico sobre Araucaria angustifolia (Bert.) O.Ktze. fotossíntese em dependência à luz no estágio juvenil. FLORESTA, v.10, n.1, p. 5-10, junho 1979.

SOARES, R.V. Considerações sobre a regeneração natural de Araucaria angustifolia. FLORESTA, v.10, n.2, p. 12-17, dezembro 1979.

1981: 1 trabalho

FERNANDES, R.R.; SOARES, R.V. Variação estacional do teor de umidade em folhagem de Pinus elliottii, Pinus taeda e Araucaria angustifolia. FLORESTA, v.12, n.2, p. 5-12, dezembro 1981.

\section{2: 2 trabalhos}

SEITZ, A. A regeneração natural de Araucaria angustifolia. SILVICULTURA EM SÃO PAULO, v.16A, parte1, p.412-420, 1982. Edição Especial. Apresentado ao Congresso Nacional sobre Essências Nativas, Campos do Jordão, 1982 - Anais.

VEIGA, A.A.; MARIANO, G. Coleta dendrométrica em povoamento não manejado de jequitibá-vermelho Cariniana legallis Mart. SILVICULTURA EM SÃO PAULO, v.16A, parte2, p.1124-1131, 1982. Edição Especial. Apresentado ao Congresso Nacional sobre Essências Nativas, Campos do Jordão. 1982 - Anais.

\section{3: 1 trabalho}

PIZZATTO, L. Critérios e Observações Práticas de Manejo Ambiental no Planejamento. Implantação e Orientação de Programas Homogêneos e Heterogêneos de Florestamento ou Reflorestamento com Essências Exóticas e Nativas; e Áreas Nativas Complementares. SILVICULTURA, n.28, p.112-115, 1983. Apresentado ao 4. Congresso Florestal Brasileiro, Belo Horizonte, 1982 - Anais.

1986: 2 trabalhos

NODARI, R.O.; GUERRA, M.P.; REIS, A. Perspectivas do palmiteiro (Euterpe edulis) no Sul do Brasil. SLVICULTURA, v.11, n.41, p.75, 1986a. Apresentado ao 5. Congresso Florestal Brasileiro, Recife, 1986 - Anais.

YAMAZOE, G.; MOURA NETTO, B.V.de; DIAS, A.C. Comportamento de Euterpe oleracea Mart. nas condições edafo-climáticas de Sete Barras (SP). SILVICULTURA. v.11, n.41, p.67, 1986. Apresentado ao 5. Congresso Florestal Brasileiro. Recife, 1986 - Anais.

\section{0: 3 trabalhos}

BARBOSA, A.P. O crescimento de mudas de caroba (Jacaranda copaia Aubl. D. Don - Bignoniaceae) cultivadas sob diferentes níveis de sombreamento e espaçamento. In: CONGRESSO FLORESTAL BRASILEIRO, 6., Campos do Jordão. 1990. Anais. Campos do Jordão: SBS/SBEF, 1990. v.3, p.526-534.

BRIENZA JÚNIOR, S.; CASTRO, R.C.A.de; VIANA, L.M. Ensaio de espécies florestais sob duas diferentes condições ecológicas: 1 . avaliações silviculturais. In: CONGRESSO FLORESTAL BRASILEIRO, 6., Campos do Jordão, 1990. Anais. Campos do Jordão: SBS/SBEF, 1990. v.3, p.616-623. 
HERING, K.G.; MEZIO, D.; LONGO, A.N. Árvores gemuladas no manejo florestal. In: CONGRESSO FLORESTAL BRASLEIRO, 6., Campos do Jordão, 1990. Anais. Campos do Jordão: SBS/SBEF, 1990. v.3, p.610-612.

1992: 11 trabalhos

AGUIAR, F.F.A.; SILVA FILHO, N.L.da Observações sobre o comportamento de Euterpe edulis Mart. (palmito doce) em mata ciliar. Revista do Instituto Florestal. v.4, parte 3, p.679-683, 1992. Edição Especial. Apresentado ao 2. Congresso Nacional sobre Essências Nativas, São Paulo, 1992 - Anais.

BARBOSA, J.M.; BARBOSA, L.M.; STROSS, S.R. et al. Recuperação de áreas degradadas da mata ciliar a partir de sementes. Revista do Instituto Florestal. v.4, parte 3, p.702-705, 1992. Edição Especial. Apresentado ao 2. Congresso Nacional sobre Essências Nativas, São Paulo, 1992 - Anais.

BERTALOT, M.J.A.; HARKALY, A.H. Projeto de recomposição florestal de áreas da Estância Demétria e vizinhanças. Revista do Instituto Florestal, v.4, parte 3, p.695-701, 1992. Edição Especial. Apresentado ao 2. Congresso Nacional sobre Essências Nativas, São Paulo, 1992 - Anais.

BERTONI, J.E.A. Reflorestamento com essências nativas e regeneração natural do cerrado. Revista do Instituto Florestal, v.4, parte 3, p.706-709, 1992. Edição Especial. Apresentado ao 2. Congresso Nacional sobre Essências Nativas, São Paulo, 1992 - Anais.

BUTIGNOL, C.A. Escala de desenvolvimento para palmeiras de folhas pinadas. Revista do Instituto Florestal, v.4, parte 2, p.583-584, 1992. Edição Especial. Apresentado ao 2. Congresso Nacional sobre Essências Nativas, São Paulo, 1992 - Anais.

CROMBERG, V.U.; BOVI, M.L.A. Possibilidades do uso do palmiteiro na recuperação de áreas degradadas de mineração. Revista do Instituto Florestal, v.4, parte 3, p.688-691, 1992. Edição Especial. Apresentado ao 2. Congresso Nacional sobre Essências Nativas, São Paulo, 1992 - Anais.

HERING, K.G.; MERIZIO, D.; LONGO, A.N. Árvores gemuladas no manejo natural. Revista do Instituto Florestal, v.4, parte 2, p.440-444, 1992. Edição Especial. Apresentado ao 2. Congresso Nacional sobre Essências Nativas, São Paulo, 1992 - Anais.

OGA, F.M.; FONSECA, C.E.L.da; SILVA, J.A.da Influência da profundidade de semeadura e a luminosidade na germinação de sementes de cagaita (Eugenia dysenterica Mart.). Revista do Instituto Florestal, v.4, parte 2, p.634-639, 1992. Edição Especial. Apresentado ao 2. Congresso Nacional sobre Essências Nativas, São Paulo. 1992 - Anais.

POGGIANI, F.; BRUNI, S.; BARBOSA, E.S.Q. Efeito do sombreamento sobre o crescimento das mudas de três espécies florestais. Revista do Instituto Florestal, v.4, parte 2, p.564-569, 1992. Edição Especial. Apresentado ao 2. Congresso Nacional sobre Essências Nativas, São Paulo, 1992 - Anais.

REIS, A.; FANTINI, A.C.; REIS, M.S.dos et al. Sistemas de implantação do palmiteiro (Euterpe edulis Martius). Revista do Instituto Florestal, v.4, parte 3, p.710-713, 1992. Edição Especial. Apresentado ao 2. Congresso Nacional sobre Essências Nativas, São Paulo, 1992 - Anais.

SCALON, S.P.Q; ALVARENGA, A.A.de Efeito do sombreamento sobre a formação de mudas de pau-pereira (Platycyamus regnelli Benth). ÁRVORE, v.17, n.3, p.265-270, set./dez. 1993.

1993: 3 trabalhos

GANDARA. F.B.; LEPSH-CUNHA, N. Respostas da germinação de embaúba (Cecropia pachystachya) a diferentes tamanhos de clareira e períodos de luz. In: CONGRESSO FLORESTAL BRASILEIRO, 7. Curitiba, 1993. Anais. Curitiba: SBS/SBEF, 1993. v.2, p.467-469. 
LIMA, M.F. Potencial dos recursos florestais da Região de Russas no Estado do Ceará. In: CONGRESSO FLORESTAL BRASILEIRO, 7., Curitiba, 1993. Anais. Curitiba: SBS/SBEF, 1993. v.2, p.748.

OLIVEIRA, L.C.de; SILVA, J.N.M. Crescimento e regeneração natural de Vochysia maxima ducke em uma floresta secundária no Estado do Pará. In: CONGRESSO FLORESTAL BRASILEIRO, 7., Curitiba, 1993. Anais. Curitiba: SBS/SBEF, 1993. v.1, p.329-332.

1994: 3 trabalhos

DANIEL, O.; OHASHI, S.T.; SANTOS, R.A.dos Produção de mudas de Goupia glabra (Cupiúba): efeito de níveis de sombreamento e tamanho de embalagens. ÁRVORE, v.18, n.1, p.1-13, jan./abr. 1994.

KOBIYAMA, M. Influência da minhoca-louca (Amynthas spp Rosa, 1891) sobre o movimento da água no solo, relacionada ao crescimento da bracatinga (Mimosa scabrella Benth.). FLORESTA, v.24, n.1/2, p.82, jun./dez. 1994.

REIS, G.G.dos; REIS, M.G.F.; PAULA, R.C.de; MAESTRI, M.; BORGES, E.E.L.e Crescimento e ponto de compensação lúmico em mudas de espécies florestais nativas submetidas a diferentes níveis de sombreamento. ÁRVORE, v.18, n.2, p.97-106, mai./ago. 1994.

1997: 1 trabalho

REIS, M.G.F.; REIS, G.G.dos; LELES, P.S.S. et al. Exigencias nutricionais de mudas de Dalbergia nigra (Vell.) Fr. Allem (Jacarandá-da-bahia) produzidas em dois níveis de sombreamento. FLORESTA, v.21, n.4, p.169174, out.dez. 1997.

5) Controle de Pragas

5.1) Novos Produtos

1969: 1 trabalho

BRANDÃO, A.E. Um Curuquerê do Pinheiro. FLORESTA, v.1, n.1, p.103-104, junho 1969.

1972: 1 trabalho

GRODZKI, RM. Pesquisa dos Efeitos do CS2 e CH3Br no expurgo de sementes de Araucaria angustifolia para o Combate da Lagarta de Laspeyrasia araucariae. FLORESTA, v.4, n.1, p.26-30, dezembro 1972.

1977: 1 trabalho

CLARK, E.W;; SILVA, N.A. A Ocorrência, em Minas Gerais, de Xanthozona melanopyga Wied, 1830 (Diptera: Tachinidae), um Parasito de Lagarta-das-Palmeiras Brassolis spp. (Lepidoptera: Brassolidae). ÁRVORE, v.1, n.2, p.176, setembro 1977.

1978: 1 trabalho

PEDROSA-MACEDO, J.H. Proteção Florestal. A lagarta da Araucaria Dirphia araucariae Jones, 1908 (Lep.: Saturniidae, Hemileucinae). Silvicultura, v.2, n.14, p.96-100, 1978. Edição Especial. Apresentado ao 3. CONGRESSO FLORESTAL BRASILEIRO, Manaus, 1978 - Anais.

1979: 1 trabalho

ZANÚNCIO, J.C.; SUPLICY FILHO, N.; VILELA, E.F.; FARIA, A.B. Controle químico e microbiológico de Euselasia apisaon (Lepidoptera: Rionidae) em condiçðes de laboratório e de campo. ÁRVORE, v.3, n.1, p.75-87, jan./jun.1979.

1980: 1 trabalho

MÜLLER, J.A.; MACEDO, J.H.P. Notas preliminares sobre danos causados por animais silvestres em pinhões. FLORESTA, v.11, n.2, p.35-41, dezembro 1980. 


\section{3: 6 trabalhos}

DIODATO, M.A.; SANTOS, H.R.dos; CONTO, I.de Aplicação do fungo entomopatogênico Beauveria bassiana sobre fềmeas de Sirex noctilio durante o processo de postura. In: CONGRESSO FLORESTAL BRASILEIRO, 7., Curitiba, 1993. Anais. Curitiba: SBS/SBEF, 1993. v.1, p.171-172.

DIODATO, M.A.; SANTOS, H.R dos; CARVALHO, A.G. Patogenicidade de Beauveria bassiana em larvas de Sirex noctilio, no campo e em laboratónio. In: CONGRESSO FLORESTAL BRASILEIRO, 7., Curitiba, 1993. Anais. Curitiba: SBS/SBEF, 1993. v.1, p.207-209.

DIODATO, M.A.; SANTOS, H.R.dos Patogenicidade de diversas linhagens de Beatveria bassiana em adultos de Sirex noctilio. In: CONGRESSO FLORESTAL BRASILEIRO, 7, Curitiba, 1993. Anais. Curitiba: SBS/SBEF, 1993. v.1, p.210-211.

PIRES, P.T L.; SANTOS, H.R dos Avaliação de parasitismo do nematóide Delademus siricidicola (Nematoda, neotylenchidae) e do fungo Beauveria bassiana (ocorrência natural) em larvas de vespa de madeira. Sirex noctilio na Região de Lajes - SC. In: CONGRESSO FLORESTAL BRASILEIRO, 7., Curitiba, 1993.

Anais. Curitiba: SBS/SBEF, 1993. v.1, p.176-177.

SANTOS, H.R dos; PIRES, P.T.L. Comparação da eficiência dos inimigos naturais da vespa da madeira, Sirex noctilio no Sul do Brasil. In: CONGRESSO FLORESTAL BRASILEIRO, 7., Curitiba, 1993. Anais. Curitiba: SBS/SBEF, 1993. v.1, p.178-179.

SANTOS, H.R dos; PIRES, P.T.L. Avaliação da eficiência do nematóide Delademus siricidicola bedding em adultos da vespa da madeira, Sirex noctilio fabricius, 1793. In: CONGRESSO FLORESTAL BRASILEIRO, 7., Curitiba, 1993. Anais. Curitiba: SBS/SBEF, 1993. v.1, p.173-175.

1995:1 trabalho

LARANJEIRO, A.J.; ZANÚNCIO, J.C. Avaliação da isca à base de sulfluramida no controle de Atta sexdens rubropilosa pelo processo dosagem única de aplicação. IPEF, v.48/49, p.144-152, jun./dez. 1995.

\section{2) Novas Dosagens}

\section{8: 1 trabalho}

SANTOS, G.P.; GOMES, J.M.; ZANÚNCIO, J.C.; BRANDT, R.M. Controle de Saúvas pelo Sistema de Termonebulização, na Região de Timóteo, MG. Silvicultura, v.2, n.14, p.350-351, 1978. Edição Especial. Apresentado ao 3. CONGRESSO FLORESTAL BRASILEIRO, Manaus, 1978 - Anais.

\section{9: 1 trabalho}

ZANÚNCIO, J.C.; SUPLICY FILHO, N.; VILELA, E.F,; FARIA, A.B. Controle químico e microbiológico de Euselasia apisaon (Lepidoptera: Rionidae) em condições de laboratónio e de campo. ÁRVORE, v. 3, n.1, p.75-87, jan./jun.1979.

\section{0: 3 trabalhos}

FERREIRA, F.A.; ALFENAS, A.C. Nova mancha de folha do ipê em viveiros causada por Corynospora cassiicola. ÁRVORE, v.4, n.1, p.103-, jan./jun. 1980.

FINGER, C.A.G.; MINUSSI, E. Agente causal da antracnose da timbaúva (Enterolobium contortisiquum (Vell.) Morong. sintomatologia e testes de inibição "in vitro" do patógeno. FLORESTA, v.11, n.2, p. 26-34, dezembro 1980.

MÜLLER, J.A.; MACEDO, J.H.P. Notas preliminares sobre danos causados por animais silvestres em pinhões. FLORESTA, v.11, n.2, p.35-41, dezembro 1980.

1982: 2 trabalhos 
TEIXEIRA, L.L. Controle químico da Apiosphaeria guaranitica, testando o emprego de alguns fungicidas com o objetivo de verificar o mais eficiente. SILVICULTURA EM SÃO PAULO, v.16A, parte2, p.1219-1223, 1982. Edição Especial. Apresentado ao Congresso Nacional sobre Essências Nativas, Campos do Jordão, 1982 - Anais.

VILA, W.M.; TEIXEIRA, E.P. Aplicação de inseticidas sistêmicos no controle de Cydia (Laspeyresia) araucariae Pastr. 1947 (Grapholitidae. Lepidoptera) broca das sementes do pinheiro-brasileiro. SILVICULTURA EM SÃO PAULO, v. 16A, parte2, p.1204-1208, 1982. Edịão Especial. Apresentado ao Congresso Nacional sobre Essências Nativas, Campos do Jordão, 1982 - Anais.

1983: 2 trabalhos

MARQUES, L.C.T. Produção de Mudas de Freijó (Cordia goeldiana HUBER). SILVICULTURA, n.28, p.247-251, 1983. Apresentado ao 4. Congresso Florestal Brasileiro, Belo Horizonte. 1982 - Anais.

MORAES, T.S.A.; REZENDE, G.C.de; MENDES, C.J.; SUITER FILHO, W. Estudo de Dosagens de Isca Formicida para Sauveiros Jovens. SILVICULTURA, n.28, p.364-365, 1983. Apresentado ao 4. Congresso Florestal Brasileiro, Belo Horizonte, 1982 - Anais.

1986: 1 trabalho

NUNES, M.N.; VARELA, V.P. Efeito do tratamento de sementes de cardeiro (Scleronema micranthum Ducke) - Bombacaceae, com fungicida e inseticida na germinação. SILVICULTURA, v.11, n.41, p.72, 1986. Apresentado ao 5. Congresso Florestal Brasileiro, Recife, 1986 - Anais.

1992: 3 trabalhos

DEMUNER, N.L.; FERREIRA, F.A. Fungicidas para a eradicação de de uredosporos e teliosporos de Prospodium bicolor em foliolos maduros de Ipê-Amarelo (Tabebuia serratifolia). ÁRVORE, v.16, n.3, p.368-, set./dez. 1992a.

DEMUNER, N.L.; FERREIRA, F.A.; MUCHOVEJ, J.J. Fungicidas para a proteção de folíolos maduros de mudas de Ipê-Amarelo (Tabebuia serratifolia) às infeç̧ões eciospóricas e urodospóricas de Prospodium bicolor. ÁRVORE, v.16, n.2, p.231-, mai./ago. 1992b.

DEMUNER, N.L.; FERREIRA, F.A.; MUCHOVEJ, J.J. Fungicidas para a proteção de folíolos novos de mudas de Ipê-Amarelo (Tabebuia serratifolia) às infecções basidiospóricas de Prospodium bicolor. ÁRVORE, v.16, n.1, p.118-, jan./abr. $1992 \mathrm{c}$.

\section{7: 1 trabalho}

ALVES, J.B.; ZANUNCIO, J.C.; GALO, M.V.; ZANETTI, R. Paralisação de forrrageamento e controle de Atta laevigata (F. Smith) (Hymenoptera: Formicidae) com Mirex-S (Sulfluramida) em duas metodologias de medição de formigueiros. FLORESTA, v.21, n.1, p.141-146, jan./mar. 1997.

\section{3) Novos Sistemas}

\section{2: 1 trabalho}

GRODZKI, R.M. Planejamento de Combate ao Eriococcus araucariae. FLORESTA, v.4, n.1, p.11-13, dezembro 1972.

1975: 1 trabalho

RICHTER, H.G.; NOCK, H. P.; REICHMANN NETO, F. Bicuiba (Virola oleifera). I - Aspectos dendrológicos de espécie e descrição macro e microscópia da madeira. FLORESTA. v.6, n.1, p.36-42, junho 1975.

\section{1: 1 trabalho}

OLIVEIRA, O.S.de Fungos causadores de danos em Araucaria angustifolia (Bert.) O.Ktze. FLORESTA, v.12, n.2, p.23-27, dezembro 1981 . 


\section{2: 1 trabalho}

VILA, W.M.; TEIXEIRA, E.P.; GARRIDO, M.A.O. et al. Ocorrência de Hypsipyla sp (Lepidoptera: Pyralidae) em ensaios de consorciação de Meliaceae. SILVICULTURA EM SÃO PAULO, v.16A, parte2, p.12091218, 1982. Edição Especial. Apresentado ao Congresso Nacional sobre Essências Nativas, Campos do Jordão, 1982 - Anais.

1983: 1 trabalho

ALMEIDA, A.F.de O Principio do Uso de Porta-iscas no Controle das Formigas Cortadeiras em Florestas Implantadas. SILVICULTURA, n.28, p.132-134, 1983. Apresentado ao 4. Congresso Florestal Brasileiro, Belo Horizonte, 1982 - Anais.

1986: 1 trabalho

IEDE, E.T. Controle Integrado: Uma opção ao Combate de Pragas Florestais no Brasil. SILVICULTURA, v.11, n.41, p.43-46, 1986. Apresentado ao 5. Congresso Florestal Brasileiro, Recife, 1986 - Anais.

1993: 1 trabalho

SANTOS, H.R dos Controle biológico o proteção convencional das florestas? In: CONGRESSO FLORESTAL BRASILEIRO, 7., Curitiba, 1993. Anais. Curitiba: SBS/SBEF, 1993. v.1, p.150-151.

6) Adubação

6.1) Novos Produtos

1981: 2 trabalhos

SANTOS FILHO, A.; TOURINHO, L.C.N. Caracterizações analíticas de lodo e interpretações para fins agrícolas e florestais. I - Propriedades físicas e químicas. FLORESTA, v. 12, n.1, p.44-48, junho 1981.

SANTOS FILHO, A.; TOURINHO, L.C.N. Caracterizações analiticas de lodo e interpretações para fins agrícolas e florestais. II - Composição química total. FLORESTA, v.12, n.2, p.28-35, dezembro 1981.

1982: 2 trabalhos

ALVES, S.T. Estudos sobre o pau-de-balsa (AM) Ochroma pyramidale - (Cav.) Urb. Bombacaceae. SILVICULTURA EM SÃO PAULO, v.16A, parte2, p.981-987, 1982. Edição Especial. Apresentado ao Congresso Nacional sobre Essências Nativas, Campos do Jordão, 1982 - Anais.

GUIDONI, B.A.; KONECSNI, I. Reflorestamento de Araucaria angustifolia (Bertolini) O.Kuntze na Companhia Melhoramentos de São Paulo - Indústria de Papel Caieiras. SILVICULTURA EM SÃo PAULO, v.16A, parte2, p.732-746, 1982. Edição Especial. Apresentado ao Congresso Nacional sobre Essências Nativas, Campos do Jordão, 1982 - Anais.

1986: 1 trabalho

FRANCO, A.A.; FARIA, S.M.de; SILVA, G.G.da et al. Obtenção de Rhizobium sp. Para Inoculantes de Leguminosas Arbóreas. SILVICULTURA, v.11, n.41, p.64, 1986. Apresentado ao 5. Congresso Florestal Brasileiro, Recife, 1986 - Anais.

\section{0: 1 trabalho}

OLIVEIRA, A.C.de; HAHNE, H.; FONSECA, S.da; MALUF, J.L.P. Utilização da escória de alto forno em diferentes granulometrias como fonte de $\mathrm{Ca}, \mathrm{Mg} \mathrm{e} \mathrm{K}$ em solos do cerrado. In: CONGRESSO FLORESTAL BRASILEIRO, 6., Campos do Jordão, 1990. Anais. Campos do Jordão: SBS/SBEF, 1990. v.3, p.629-632.

1993: 1 trabalho 
RIZZI, N.E. Aplicação de água residual urbana em sedimentos de solo florestal argiloso: Estudo Experimental. In: CONGRESSO FLORESTAL BRASILEIRO, 7., Curitiba, 1993. Anais. Curitiba: SBS/SBEF, 1993. v.1, p.15-19.

1996: 1 trabalho

CARNEIRO, M.A.C.; SIQUEIRA, J.O.; DAVIDE, A.C. et al. Fungo Micorrizico e Superfosfato no Crescimento de Espécies Arbóreas Tropicais. SCIENTIA FORESTALIS, n.50, p.21-36, dezembro 1996.

\section{2) Novas Dosagens}

\section{3: 2 trabalhos}

Tolerância do pinheiro do Paraná (Araucaria angustifolia (Bert.) O.Ktze) a teores crescentes de alumínio. IPEF, v.6, p.93, 1973.

Efeitos da omissão de nutrientes na alimentação mineral do pinheiro do paraná Araucaria angustifolia (Bert.) O.Ktze cultivada em vaso. IPEF, v.7, p.3-48, 1973.

\section{4: 1 trabalho}

POGGIANI, F. Efeito de alguns nutrientes sobre o crescimento inicial de duas espécies arbóreas do cerrado. IPEF, v.8, p.3-18, outubro 1974.

\section{6: 2 trabalhos}

HILDEBRAND, E.E.; BLUM, W.E.H.; DIETRICH, A.B. Metodologia da amostragem e análise quimica das acículas da Araucaria angustifolia (Bert.) O.Ktze - II - Influência do local de amostragem na capa. FLORESTA, v.7, n. 2, p.9-15, dezembro 1976.

REISSMANN, C.B.; HILDEBRAND, E.E.; BLUM, WE.H. ; BURGER, L.M. Metodologia da amostragem e análise de acículas da Araucaria angustifolia Bert. O.Ktze. FLORESTA, v.7, n. 1, p.5-12, junho 1976.

\section{7: 1 trabalho}

TOSIN, J.C. Influência de Pinus elliotii, Engelm., da Araucaria angustifolia (Bert.) O.Ktze e da mata nativa sobre a atividade da microflora do solo. FLORESTA, v.8, n. 1, p.73-74, junho 1977.

\section{2: 1 trabalho}

YAMAZOE, G.; MOURA NETTO, B.V.de Comportamento do assai (Euterpe oleracea Mart.) frente ás condições de Sete Barras. SILVICULTURA EM SÃO PAULO, v.16A, parte2, p.837-840, 1982. Edição Especial. Apresentado ao Congresso Nacional sobre Essências Nativas, Campos do Jordão, 1982 - Anais.

\section{5: 1 trabalho}

CARDOSO, D.J.; DURIGAN, M.E.; SANGUETTA, C.R.; REISSMANN, C.B. Comportamento da bracatinga (Mimosa scabrella Benth) sob cinco níveis de fósforo - informe preliminar. FLORESTA, v. 16, n. 1 e n.2, p.49-63, jun./dez. 1985.

\section{2: 3 trabalhos}

AGUIAR, FF.A.; KANASHIRO, S. Influência da calagem, adubação mineral e orgânica sobre o crescimento inicial do palmiteiro. Revista do Instituto Florestal, v.4, parte 2, p.630-633, 1992. Edição Especial. Apresentado ao 2. Congresso Nacional sobre Essências Nativas, São Paulo, 1992 - Anais.

COSTA FILHO, R.T.da Crescimento de mudas de aroeira (Astronium urundeuva) (Fr.All)Engl) em resposta à calagem, fósforo e potássio. Revista do Instituto Florestal, v.4, parte 2, p.537-543, 1992. Edição Especial. Apresentado ao 2. Congresso Nacional sobre Essências Nativas, São Paulo, 1992 - Anais. 
DIAS, L.E.; JUCKSCH, I. ALVAREZ. V.H.; BRIENZA JR, N.F.B.S. Formação de mudas de Taxi-Branco (Sclerolobium paniculatum Voguel): II. Resposta a nitrogênio, potássio e enxofre. ÁRVORE, v.16, n.2, p.135-143, mai./ago 1992.

1993: 1 trabalho

SOUZA, A.D.de; GONÇALVES, J.L.; GONÇALVES, J.C. Efeito de dosagens de fósforo com presença ou não de calcário em diferentes espécies arbóreas nativas. In: CONGRESSO FLORESTAL BRASILEIRO, 7., Curitiba, 1993. Anais. Curitiba: SBS/SBEF, 1993. v.2, p.759.

1995: 6 trabalhos

BRAGA, F.A.; VALE, F.R.do; VENTORIM, E.A.; LOPES, G.A. Exigências Nutricionais de Quatro Espécies Florestais. ÁRVORE, v.19, n.1, p.18-31, jan./mar. 1995.

CHAVES, L.F.C.; BORGES, R.C.G.; NEVES, J.C.L.; REGAZZI. A.J. Crescimento de Mudas de Jacarandá-daBahia (Dalbergia nigra (Vell.) Fr. Allem.) em Resposta a Inoculação com Fungos Micorrizicos VesículoArbusculares em Diferentes Niveis de Fósforo no Solo. ÁRVORE, v.19, n.1, p.32-49, jan./mar. 1995.

FARIA, M.P.de; SIQUEIRA, J.O.de; VALE, F.R.do; CURI, N. Crescimento de leguminosas arbóreas em resposta a fósforo, nitrogênio, fungo micorrizico e rizóbio. I. Albizia lebbeck (L.) Benth. ÁRVORE, v.19, n.3, p.293-307, jul./set. 1995a.

FARIA, M.P.de; SIQUEIRA, J.O.de; VALE, F.R.do; CURI, N. Crescimento de leguminosas arbóreas em resposta a fósforo, nitrogênio, fungo micorrízico e rizóbio. II. Peltophorum dubium (Spreng.) Taub. ÁRVORE, v.19, n.4, p.433-446, out./dez. 1995b.

MUNIZ, A.S.; SILVA, M.A.G.da Exigências Nutricionais de Mudas de Peroba-Rosa (Aspidosperma polyneuron Muller Argoviensis) em Solução Nutritiva. ÁRVORE, v.19, n.2, p.263-271, abr./jun. 1995.

SILVA, M.A.G.da; MUNIZ, A.S.; Exigências Nutricionais de Mudas de Cedro (Cedrela fissilis Vellozo) em Solução Nutritiva. ÁRVORE, v.19, n.3, p.415-, jul./set. 1995.

1996: 1 trabalho

FERNÁNDEZ, J.Q.P.; RUIVO, M.L.P.; DIAS, L.E. et al. Crescimento de mudas de Mimosa tenuiflora submetidas a diferentes niveis de calagem e doses de fósforo, potássio e enxofre. FLORESTA, v. 20, n.4, p.425-432, out./dez.. 1996.

1997: 1 trabalho

REIS, M.G.F.; REIS, G.G.dos; LELES, P.S.S. et al. Exigencias nutricionais de mudas de Dalbergia nigra (Vell.) Fr. Allem (Jacarandá-da-bahia) produzidas em dois níveis de sombreamento. FLORESTA, v.21, n.4, p.169174, out./dez. 1997.

\section{3) Calagem e Gessagem}

\section{2: 2 trabalhos}

AGUIAR, F.F.A.; KANASHIRO, S. Influência da calagem, adubação mineral e orgânica sobre o crescimento inicial do palmiteiro. Revista do Instituto Florestal, v.4, parte 2, p.630-633, 1992. Edição Especial. Apresentado ao 2. Congresso Nacional sobre Essências Nativas, São Paulo, 1992 - Anais.

COSTA FLHO, R.T.da Crescimento de mudas de aroeira (Astronium unundeuva) (Fr.All)Engl) em resposta à calagem, fósforo e potássio. Revista do Instituto Florestal, v.4, parte 2, p.537-543, 1992. Edição Especial. Apresentado ao 2. Congresso Nacional sobre Essências Nativas, São Paulo, 1992 - Anais.

1993: 1 trabalho 
SOUZA, A.D.de; GONÇALVES, J.L.; GONÇALVES, J.C. Efeito de dosagens de fósforo com presença ou não de calcário em diferentes espécies arbóreas nativas. In: CONGRESSO FLORESTAL BRASILEIRO, 7., Curitiba, 1993. Anais. Curitiba: SBS/SBEF, 1993. v.2, p.759.

1996: 1 trabalho

FERNÁNDEZ, J.Q.P;; RUIVO, M.L.P.; DIAS, L.E. et al. Crescimento de mudas de Mimosa tenuiflora submetidas a diferentes níveis de calagem e doses de fósforo, potássio e enxofre. FLORESTA, v. 20, n.4, p.425-432, out./dez.. 1996.

7) Mecanização

\section{1) Sementes/Plantio}

1973: 1 trabalho

PINHEIRO, J.G. Semeadura mecanizada de araucaria. In: CONGRESSO FLORESTAL BRASILEIRO, 2.,Curitiba, 1973. Anais. Curitiba: 1973. p.92-93.

\section{2) Manejo}

\section{3: 1 trabalho}

KOHUT, R. Algumas observações sobre as plantações de Araucaria angustifolia nos campos paranaenses. In: CONGRESSO FLORESTAL BRASILEIRO, Curitiba. 1953. Anais. Curitiba: Instituto Nacional do Pinho. 1953. p.137-142.

\section{2: 1 trabalho}

CRUZ, J.M.da; NOGUEIRA, S.B.; PEREIRA, A.R.; NEVES, B.O. Adaptação de uma motocicleta para termonebulização no controle de formigas saúvas (Atta spp), em áreas reflorestadas de cerrado. ÁRVORE, v.8, n.2, p.104-111, jul./dez. 1984 .

\section{3: 1 trabalho}

CAMPINHOS JÚNIOR E; ALVES, J.E.M.; SANTOS, J.S.F.dos; SOUZA, W.de Desenvolvimento de Equipamento para Aplicação de Formicida Termonebulizável. SILVICULTURA, n.28, p.229-230, 1983. Apresentado ao 4. Congresso Florestal Brasileiro, Belo Horizonte, 1982 - Anais.

1993: 1 trabaho

KOBIYAMA, M.; USHIWATA, C.T. Influence of compaction on physical properties of a foresta soil. In: CONGRESSO FLORESTAL BRASILEIRO, 7., Curitiba, 1993. Anais. Curitiba: SBS/SBEF, 1993. v.1, p.254-258.

\section{3) Exploração}

\section{0: 1 trabalho}

MENDONÇA FILHO, W.F.; PEREIRA FILHO, L.P.A. Análise operacional de sestemas de abate mecanizado. In: CONGRESSO FLORESTAL BRASILEIRO, 6., Campos do Jordão, 1990. Anais. Campos do Jordão: SBS/SBEF, 1990. v.3, p.47-51.

\section{3: 6 trabalhos}

DONATI, Z.A.; ROLDI, L.M. Treinamento operacional em atividades de colheita e transporte de madeira: a experiência da Aracruz. In: CONGRESSO FLORESTAL BRASILEIRO, 7., Curitiba, 1993. Anais. Curitiba: SBS/SBEF, 1993. v.2, p.688-692.

MALINOVSKI, J.R. A colheita e o transporte de produtos florestais: uma visão global. In: CONGRESSO FLORESTAL BRASLEIRO, 7., Curitiba. 1993. Anais. Curitiba: SBS/SBEF, 1993. v.1, p.355-358. 
RIBAS JÚNIOR, U.; MENDES NETO, J. O uso do guincho de arraste na colheita florestal. In: CONGRESSO FLORESTAL BRASILEIRO, 7., Curitiba, 1993. Anais. Curitiba: SBS/SBEF, 1993. v.2, p.682-685.

SOUZA, A.P.de O uso de técnicas ergonômicas nas atividades de colheita de madeira. In: CONGRESSO FLORESTAL BRASILEIRO, 7., Curitiba, 1993. Anais. Curitiba: SBS/SBEF, 1993. v.1, p.343-346.

VOLPATO, C.E.S.; MACHADO, C.C.; SOUZA, A.P.de Estudo do tempo e movimento em uma operação de extração florestal com guincho-arrastado. In: CONGRESSO FLORESTAL BRASILEIRO, 7., Curitiba, 1993. Anais. Curitiba: SBS/SBEF, 1993. v.2, p.679-681.

ZICH, G.L. A mecanização na colheita florestal. In: CONGRESSO FLORESTAL BRASILEIRO, 7., Curitiba, 1993. Anais. Curitiba: SBS/SBEF, 1993. v.1, p.350-354.

1996: 1 trabalho

REIS, J.A.N.; SOUZA, A.P.de; MACHADO, C.C.; VIEIRA, L.B. Desenvolvimento de um equipamento de baixo custo para extração de madeira. FLORESTA. v.20, n.3, p.395-406, jul./set.1996.

8) Gerencial

\section{1) Inventário}

1971: 1 trabalho

HOSOKAWA, R.T.; KAJIVA, S. Ensaio da Aplicabilidade da Fórmula Franco-Inglesa como Modelo Matemático para a Volumetria dos Produtos de Desbaste da Araucaria angustifolia para a Indústria Papeleira. FLORESTA, v.3, n.2, p.75-82, novembro 1971.

1972: 1 trabalho

HOSOKAWA, R.T.; MACEDO, J.N. Estudos das Funções Hipsométricas em Araucaria angustifolia. FLORESTA, v.4, n.1, p.31-39, dezembro 1972.

1973: 1 trabalho

MACHADO, S.A. Aplicabilidade de equações de regressão em inventários florestais. In: CONGRESSO FLORESTAL BRASILEIRO, 2., Curitiba, 1973. Anais. Curitiba: 1973. p.175-177.

1977: 2 trabalhos

QUEIROZ, W.T. Efeitos da variação estrutural em unidades amostrais na aplicação do processo de amostragem em conglomerados nas florestas do Planalto Tapajós. FLORESTA, v.8, n. 1, p.19-23, junho 1977.

SIQUEIRA, J.D.P. Tabelas de Volume para povoamentos nativos de Araucaria angustifolia (Bert.) Ktze, no sul do Brasil. FLORESTA, v.8, n.1, p.7-12, junho 1977.

1982: 2 trabalhos

FIGUEIREDO FILHO, A. Estudos de modelos matemáticos para estimar o volume por unidade de área em uma floresta tropical úmida da Amazônia brasileira. FLORESTA. v.13, n.1, p.7, junho 1982.

SEITZ, A. A regeneração natural de Araucaria angustifolia. SILVICULTURA EM SÃO PAULO, v.16A, partel, p.412-420, 1982. Edição Especial. Apresentado ao Congresso Nacional sobre Essências Nativas, Campos do Jordão, 1982 - Anais.

\section{3: 4 trabalhos}

AHRENS, S. Importância da Distribuição de Resíduos de Regressão na Seleção de Equações de Volume. SILVICULTURA, n.28, p.609-614. 1983. Apresentado ao 4. Congresso Florestal Brasileiro, Belo Horizonte, 1982 - Anais. 
CHO, M.; AOKI, H. Inventário Florestal através do Uso de Fotografias Aéreas Verticais. SILVICULTURA. n.28, p.623-623, 1983. Apresentado ao 4. Congresso Florestal Brasileiro, Belo Horizonte, 1982 - Anais.

HIGUCHI, N.; SANTOS, J.dos; JARDIM, F.C.S. Tamanho de Parcela Amostral para Inventários Florestais. SILVICULTURA, n.28, p.649-656, 1983. Apresentado ao 4. Congresso Florestal Brasileiro, Belo Horizonte, 1982 - Anais.

RIBEIRO, RA.S. Inventário Florestal para a Região Amazônica - INVENT. SILVICULTURA, n.28, p.690694, 1983. Apresentado ao 4. Congresso Florestal Brasileiro, Belo Horizonte, 1982 - Anais.

\section{6: 1 trabalho}

LEITE, E.J.; HAY, J.D. Regeneração natural de Garapa, Apuleia leiocarpa (Vog. Macbr.), numa reserva genética em Brasilia, D.F. SILVICULTURA, v.11, n.41, p.169, 1986. Apresentado ao 5. Congresso Florestal Brasileiro, Recife, 1986 - Anais.

1988: 1 trabalho

GOMES, F.P.; CHAVES, R. A amostragem ótima em inventário florestal. IPEF, v.38, p. 17-22, abril 1988.

\section{9: 2 trabalhos}

DISPERATI, A.A.; SKALSKI JUNIOR, J. Contagem de copas de pinheiro do paraná em fotografias áereas verticais ( convencionais e $35 \mathrm{~mm}$ coloridas): caso de estudo do capão da imbuia - Curitiba, PR. FLORESTA, v.19, n.1/2, p. 4-14, 1989.

KIRCNER, F.F.; FIGUEIREDO FILHO, A.; SCOLFORO, J.R.S.; MACHADO, S.A.; MITISHITA, E.A.O uso de funções spline no cálculo de volumes de árvores. FLORESTA, v.19, n.1/2, p. 116-, 1989.

\section{0: 3 trabalhos}

AMORIM, H.B.; PÉLLICO NETO, S.P. Inventário florestal nacional uma proposta para o caso brasileiro. In: CONGRESSO FLORESTAL BRASILEIRO, 6., Campos do Jordão, 1990. Anais. Campos do Jordão: SBS/SBEF, 1990. v.3, p.138-144.

KIRCHNER, F.F.; FIGUEIREDO FILHO, A.; SCOLFORO, J.R.S. et al. O uso de funções "spline"no cálculo de volume de árvores. In: CONGRESSO FLORESTAL BRASILEIRO, 6., Campos do Jordão. 1990. Anais. Campos do Jordão: SBS/SBEF, 1990. v.3, p.105-110.

LINGNAU, C. KIRCHNER, F.F; MACEDO, J.H.P. Avaliação de dados em povoamentos de Araucaria angustifolia. In: CONGRESSO FLORESTAL BRASILEIRO, 6., Campos do Jordão, 1990. Anais. Campos do Jordão: SBS/SBEF, 1990. v.3, p.100-104.

1991: 1 trabalho

SOUZA, A.L.de; JESUS, R.M.de Equações de volume comercial e fator de forma para espécies da Mata Atlântica ocorrentes na reserva florestal da Companhia Vale do Rio Doce, Linhares, ES. ÁRVORE. v.15, n.3, p.257-273, set./dez. 1991 .

\section{2: 1 trabalho}

DURIGAN, G.; GARRIDO, M.A.O. Dendrometria de essências nativas. Revista do Instituto Florestal, v.4, parte 2, p.548-552, 1992. Edição Especial. Apresentado ao 2. Congresso Nacional sobre Essências Nativas, São Paulo, 1992 - Anais.

\section{3: 10 trabalhos}

BOHRER, C.B.A.; CAMPOS, A.N.S. Estimativa da biomassa florestal na Amazônia Legal a partir de dados provenientes de inventário florestal. In: CONGRESSO FLORESTAL BRASILEIRO, 7., Curitiba, 1993. Anais. Curitiba: SBS/SBEF, 1993. v.2, p.511. 
BRENA, D.A.; PÉLLICO NETTO, S. Metodologia para determinação da intensidade amostral em inventários florestais contínuos com dupla amostragem. In: CONGRESSO FLORESTAL BRASILEIRO, 7., Curitiba, 1993. Anais. Curitiba: SBS/SBEF, 1993, v.2, p.525-527.

DISPERATI, A.A.; FOFANO JÚNIOR, A. Fotografias aéreas $35 \mathrm{~mm}$ colorido normal, em escala grande, de uma área de vegetação natural, obtidas de ultraleve. In: CONGRESSO FLORESTAL BRASILEIRO, 7., Curitiba, 1993. Anais. Curitiba: SBS/SBEF, 1993. v.2, p.512-515.

KRONKA, F.J.N.; MATSUKUMA, C.K.: NALON, M.A. et al. Inventário florestal do Estado de São Paulo. In: CONGRESSO FLORESTAL BRASILEIRO, 7., Curitiba, 1993. Anais. Curitiba: SBS/SBEF, 1993. v.2, p.520-521.

MACHADO, S.A.; NADOLNY, M.C. Acuracidade da cubagem de árvores pelos métodos de hohenadl, fao e gráfico, comparativamente a xilometro. In: CONGRESSO FLORESTAL BRASILEIRO, 7., Curitiba, 1993. Anais. Curitiba: SBS/SBEF, 1993. v.2, p.478-480.

MARTINS NETTO, D.A. Aspectos demográficos de quatro especies florestais na mata de galeria da reserva genética do Tamanduá - DF. In: CONGRESSO FLORESTAL BRASILEIRO, 7., Curitiba, 1993. Anais. Curitiba: SBS/SBEF, 1993. v.1, p.325-328ii.

SCOLFORO, J.R.; MACHADO, S.A.; HOSOKAWA, R.T. Análise das estimativas de um sistema de crescimento e produção compativel entre o modelo global do povoamento e o modelo por classe diamétrica. In: CONGRESSO FLORESTAL BRASILERO, 7., Curitiba, 1993. Anais. Curitiba: SBS/SBEF, 1993. v.2, p.481-487.

SCOLFORO, J.R. Técnicas de predição presente e futura do crescimento e da produção como suporte para o manejo florestal. In: CONGRESSO FLORESTAL BRASILEIRO, 7., Curitiba, 1993. Anais. Curitiba: SBS/SBEF, 1993. p.265-270.

SILVA, J.A.A.da; MACHADO, S.A.; BORDERS, B.E.; BAIlEY, RL. Uma nova metodologia para construção de tabelas volumétricas. In: CONGRESSO FLORESTAL BRASILEIRO, 7., Curitiba, 1993. Anais. Curitiba: SBS/SBEF, 1993. v.2, p.557-558.

YARED, J.A.G.; LEITE, H.G.; SILVA. R.R.F.da Volumetria e fator de forma de morototó (Didymopamax morototonii Aubl. Decne et Planch) sob diferentes espaçamentos. In: CONGRESSO FLORESTAL BRASILEIRO, 7., Curitiba. 1993. Anais. Curitiba: SBS/SBEF, 1993. v.2, p.570-573.

1994: 3 trabalhos

GERING, L.R.; SILVA, J.A.A.; MACHADO, S.A. Inventário florestal contínuo com reposição parcial de unidades amostrais. FLORESTA, v.24, n.1/2, p.3-22, jun./dez. 1994.

MOURA, J.B. Estudo da forma do fuste e comparação de métodos de estimativa volumétrica de espécies florestais da Amazônia brasileira. FLORESTA, v.24, n.1/2, p.86, jun./dez. 1994.

PÉLLICO NETO, S.; SANQUETTA, C.R. Determinação do número de estratos em estratificação volumétrica de florestas naturais e plantadas. FLORESTA, v.24, n.1/2, p.49-60, jun./dez. 1994.

1995: 1 trabalho

LEITE, H.G.; GUIMARÃES, D.P.; CAMPOS, J.C.C. Descrição e Emprego de Um Modelo para Estimar Múltiplos Volumes de Árvores. ÁRVORE, v.19, n.1, p.65-79, jan./mar. 1995.

1997: 1 trabalho

SILVA, G.F.da; CAMPOS, J.C.C.; SOUZA. A.L.de; LEITE, H.G. Uso de métodos estatísticos para comparar alternativas de estimação do volume comercial. FLORESTA. v.21, n.1, p.59-70, jan./mar. 1997.

8.2) Especialização/Otimização 
1953: 2 trabalhos

SAUR, W.W. Formas de exploração racional das florestas. In: CONGRESSO FLORESTAL BRASILEIRO, Curitiba, 1953. Anais. Curitiba: Instituto Nacional do Pinho, 1953. p.275-290.

WIELICZKA, Z. Custo e rentabilidade das plantações de Araucaria angustifolia. In: CONGRESSO FLORESTAL BRASILEIRO, Curitiba, 1953. Anais. Curitiba: Instituto Nacional do Pinho, 1953. p.107114.

1975: 1 trabalho

VEIGA, R.A.A.;VEIGA, A.A. Relações entre porcentagem de extração e taxa de acréscimo diametral em desbastes florestais. FLORESTA, v.6, n.1, p.31-35, junho 1975.

1976: 3 trabalhos

DISPERATI, A.A.; CKEECH, M.A. Uso da Imagem de satélite para o desenvolvimento florestal. FLORESTA, v.7, n. 1, p.46-51, junho 1976.

HIIDEBRAND, E.E.; BLUM, W.E.H.: DIETRICH, A.B. Metodologia da amostragem e análise química das acículas da Araucaria angustifolia (Bert.) O.Ktze - II - Influência do local de amostragem na capa. FLORESTA, v.7, n. 2, p.9-15, dezembro 1976.

REISSMANN, C.B.; HILDEBRAND. E.E.; BLUM, W.E.H. ; BURGER, L.M. Metodologia da amostragem e análise de acículas da Araucaria angustifolia Bert. O.Ktze. FLORESTA, v.7, n. 1, p.5-12, junho 1976.

1977: 1 trabalho

DIETRICH, A.B. Relações entre dados analíticos de solo, análise foliar e dados de crescimento da Araucaria angustifolia (Bert.) O.Ktze. FLORESTA, v.8, n.1, p.81-84, junho 1977.

1978: 1 trabalho

HOSOKAWA, R.T. Utilização racional dos pinheiros nativos. FLORESTA, v.9, n.1, p.24-26, junho 1978.

1983: 5 trabalhos

ANCILLOTTI, R.N.; SANTOS, R.J.dos; OLIVEIRA, E.S.de; OST,V. Evolução Metodológica no Corte e Tranporte de Madeira - "Feed-back" do Treinamento. SILVICULTURA, n.28, p.551-555, 1983. Apresentado ao 4. Congresso Florestal Brasileiro, Belo Horizonte, 1982 - Anais.

LACERDA, E. A Motosserra na Exploração Florestal - Aspectos Ergonômicos no seu Uso - A Segurança e a Medicina do Trabalho. SILVICULTURA, n.28, p.551-555, 1983. Apresentado ao 4. Congresso Florestal Brasileiro, Belo Horizonte, 1982 - Anais.

OGAWA, H.Y.; NOFFS, M.S.; NEGREIROS, O.C.de; MORAES, A.L.de Emprego do Sistema Cartográfico para Zoneamento do Uso do Solo. SILVICULTURA, n.28, p.103-105, 1983. Apresentado ao 4. Congresso Florestal Brasileiro, Belo Horizonte, 1982 - Anais.

PEREIRA, A.R. Segurança do Trabalho na Empresa Florestal. SILVICULTURA, n.28, p.632-639, 1983. Apresentado ao 4. Congresso Florestal Brasileiro, Belo Horizonte, 1982 - Anais.

PIZZATTO, L. Critérios e Observações Práticas de Manejo Ambiental no Planejamento, Implantação e Orientação de Programas Homogêneos e Heterogêneos de Florestamento ou Reflorestamento com Essências Exóticas e Nativas; e Áreas Nativas Complementares. SILVICULTURA, n.28, p.112-115, 1983. Apresentado ao 4. Congresso Florestal Brasileiro, Belo Horizonte, 1982 - Anais.

\section{4: 1 trabalho}

HOSOKAWA, R.T.; MENDES, J.B. Planejamento florestal. FLORESTA, v.15, n.1 e n.2, p.4-7, dezembro 1984. 
1985: 1 trabalho

OLIVEIRA, I.M.V.; SEIXAS, F. Estudo da dieta balanceada para operadones de moto-serra. IPEF, v.30, p.1928 , agosto 1985 .

1987: 1 trabalho

LOCH, C.; KIRCHNER, F.F.; HOSOKAWA, R.T. Ordenamento Espacial de uma Floresta. FLORESTA, v.17, n.1 e n.2, p.45, jun./dez. 1987.

1988: 1 trabalho

CAMPOS, J.C.C.; CAMPOS, A.L.A.S.; LEITE, H.G. Decisão silvicultural empregando um sistema de predição do crescimento e da produção. ÁRVORE, v.12, n.2, p.100-110, jul./dez. 1988.

1990: 3 trabalhos

DISPERATI, A.A.; SKALSK JÚNIOR, J. Contagem de copas de Pinheiro do Paraná em fotografias aéreas verticais (convencionais e $35 \mathrm{~mm}$ coloridas): caso estudo do Capão da Imbúia Curitiba-PR In: CONGRESSO FLORESTAL BRASILEIRO, 6., Campos do Jordão, 1990. Anais. Campos do Jordão: SBS/SBEF, 1990. v.3, p.91-99.

LINGNAU, C. KIRCHNER, F.F.; MACEDO, J.H.P. Avaliação de dados em povoamentos de Araucaria angustifolia. In: CONGRESSO FLORESTAL BRASILEIRO, 6., Campos do Jordão, 1990. Anais. Campos do Jordão: SBS/SBEF, 1990. v.3, p.100-104.

MENDONÇA FILHO, W.F.; PEREIRA FILHO, L.P.A. Análise operacional de sestemas de abate mecanizado. In: CONGRESSO FLORESTAL BRASILEIRO, 6., Campos do Jordão, 1990. Anais. Campos do Jordão: SBS/SBEF, 1990. v.3, p.47-51.

1991: 2 trabalhos

DISPERATI, A.A. O uso do sensoriamento remoto no estudo de pragas florestais. FLORESTA v.21, n.1/2, p.13-26, jun./dez. 1991 .

PONZONI, F.J.; DISPERATI, A.A. Aplicação do modelo SAIl no estudo da reflectância espectral de dosséis de mudas de Eucalyptus sp. e de Aspidosperma sp. FLORESTA v.21, n.1/2, p.45-70, jun./dez. 1991.

1992: 1 trabalho

AGUIAR, F.F.A.; SILVA FILHO, N.L.da Observações sobre o comportamento de Euterpe edulis Mart. (palmito doce) em mata ciliar. Revista do Instituto Florestal. v.4, parte 3, p.679-683, 1992. Edição Especial. Apresentado ao 2. Congresso Nacional sobre Essências Nativas, São Paulo, 1992 - Anais.

1993: 11 trabalhos

CARNIERI, C. Técnicas de otimização para tomadas de decisão em manejo florestal. In: CONGRESSO FLORESTAL BRASILEIRO, 7., Curitiba, 1993. Anais. Curitiba: SBS/SBEF, 1993. p.264.

CARNIERI, C; SCOLFORO, J.R.S. O algoritimo gub como elemento de viabilização do processo de otimização de planos de manejo. In: CONGRESSO FLORESTAL BRASILEIRO, 7., Curitiba, 1993. Anais. Curitiba: SBS/SBEF, 1993. v.2, p.531-534.

COUTINHO, S.C. Qualidade e produtividade de empreendimentos florestais em regiões tropicais úmidas. In: CONGRESSO FLORESTAL BRASILEIRO, 7., Curitiba, 1993. Anais. Curitiba: SBS/SBEF, 1993. p.190-194.

COSTA FILHO, P.P. Custos de exploração e transporte de madeira em empreendimentos florestais na Amazônia. In: CONGRESSO FLORESTAL BRASILEIRO. 7., Curitiba, 1993. Anais. Curitiba: SBS/SBEF, 1993. p.347-349. 
DONATI, Z.A.; ROLDI, L.M. Treinamento operacional em atividades de colheita e transporte de madeira: a experiência da Aracruz. In: CONGRESSO FLORESTAL BRASILEIRO, 7., Curitiba, 1993. Anais. Curitiba: SBS/SBEF, 1993. v.2, p.688-692.

KIRCHNER, F.F. O sistema geográfico de informações na precisão e qualidade da avaliação florestal. In: CONGRESSO FLORESTAL BRASILEIRO, 7., Curitiba, 1993. Anais. Curitiba: SBS/SBEF, 1993. p.260263.

LIMA, J.T.; FRANCO, E.J.; PENATI, J.E. Eficiência de utilização de um xilômetro construído para medição de amostras de madeira. In: CONGRESSO FLORESTAL BRASILEIRO, 7., Curitiba, 1993. Anais. Curitiba: SBS/SBEF, 1993. v.2, p.769.

OLIVEIRA, A.C.de Gerenciamento da qualidade total na atividade florestal. In: CONGRESSO FLORESTAL BRASILEIRO, 7., Curitiba, 1993. Anais. Curitiba: SBS/SBEF, 1993. p.296-300.

SCOLFORO, J.R.S. Simulação de desbastes seletivos através de modelo matemático. In: CONGRESSO FLORESTAL BRASILEIRO, 7., Curitiba, 1993. Anais. Curitiba: SBS/SBEF, 1993. v.2, p.549-552.

TRINDADE, C.; SARTÓRIO, M.L.; REZENDE, J.L.P. PAIVA. H.N.de Cep - controle estatístico de processso na atividade florestal. In: CONGRESSO FLORESTAL BRASILEIRO, 7., Curitiba, 1993. Anais. Curitiba: SBS/SBEF, 1993. v.2, p.769.

VOLPATO, C.E.S.; MACHADO, C.C.; SOUZA, A.P.de Estudo do tempo e movimento em uma operação de extração florestal com guincho-arrastado. In: CONGRESSO FLORESTAL BRASILEIRO, 7., Curitiba, 1993. Anais. Curitiba: SBS/SBEF, 1993. v.2, p.679-681.

1995: 2 trabalhos

GOMES, F.P.; GARCIA, C.H. A produção de madeira de custo mínimo. IPEF, v.48/49, p.153, jun./dez. 1995.

PÉlLICO NETTO, S.; SANQUETTA, C.R.; MENDES, J.B. Definição dos limites volumétricos em estratificação de florestas plantadas. FLORESTA, v.25, n.1/2, p.17-30, jun./dez. 1995.

\section{6: 2 trabalhos}

BRITES, R.S.; SOARES, V.P.; RIBEIRO, C.A.A.S. Verificação da exatidão em classificações de uma imagem orbital mediante a utilização de três indices. FLORESTA, v.20, n.3, p.415, jul./set. 1996.

NEVES, A.R.; REZENDE, J.L.P.de Comparação entre projetos pelo critério da taxa interna de retorno: problemas e soluções alternativas. FLORESTA, v.20, n.2, p.217-228, abr.juun. 1996.

\section{7: 7 trabalhos}

BRITES, R.S.; SOARES,V.P.; RIBEIRO, C.A.A.S. Efeitos da estratégia de amostragem na exatidão reportada pelo índice Kappa na classificação de imagens orbitais. FLORESTA, v.21, n.1, p.155-162, jan./mar. 1997.

FANTINI, A.C.; NODARI, R.O.; REIS, M.S.dos et al. Estimativas da produção de palmito em plantas de palmiteiro (Euterpe edulis Martius) a partir de características fenotípicas. FLORESTA, v.21, n. 1, p.49-58, jan./mar. 1997.

FONTES, JM.; MACHADO, C.C.; SOUZA, A.P.de et al. Desenvolvimento de um sistema informatizado para planejamento e controle de manutenção em máquinas florestais: SIPLAM. FLORESTA, v.21, n.2, p.279288, abr.jun. 1997.

LOPES, E.S.; SOUZA, A.P.de; MACHADO, C.C.; NEVES, A.R. Avaliação do treinamento de operadores de motosserra no corte florestal - um estudo de caso. FLORESTA, v.21, n.3, p.369-376, jul./set. 1997.

REZENDE, J.L.P.de; VALVERDE, S.R. Princípios de depreciaçao de máquinas e equipamentos. FLORESTA, v.21, n.1, p.99-112, jan./mar. 1997. 
SANT'ANNA, C.M.; SOUZA, A.P.de; BRAGA, G.M.; MACHADO, C.C. Avaliação da satisfação no trabalho de operadores de motosserra. FLORESTA, v.21, n.1, p.131-140, jan./mar. 1997.

VALVERDE, S.R.; REZENDE, J.L.P. Substituição de máquinas e equipamentos: métodos e aplicações. FLORESTA, v. $21, \mathrm{n} .3$, p.353-364, jul./set. 1997.

\section{3) Informática}

\section{1: 1 trabalho}

HOSOKAWA, R.T.; KAJIVA, S. Ensaio da Aplicabilidade da Fórmula Franco-Inglesa como Modelo Matemático para a Volumetria dos Produtos de Desbaste da Araucaria angustifolia para a Indústria Papeleira. FLORESTA, v.3, n.2, p.75-82, novembro 1971.

\section{3: 1 trabalho}

FERREIRA, H.C. Utilização de computadores em inventários florestais. In: CONGRESSO FLORESTAL BRASILEIRO, 2., Curitiba, 1973. Anais. Curitiba: 1973. p.220-227.

1976: 1 trabalho

HOSOKAWA, R.T. A simulação como instrumental de planejamento florestal. FLORESTA. v.7, n.2, p.16-24, dezembro 1976.

\section{3: 3 trabalhos}

FERREIRA, R.; SALTON, A.; MESQUITA, J.; BRAIBANTE, J.A.S. Planejamento Florestal através do Computador. SILVICULTURA, n.28, p.632-639, 1983. Apresentado ao 4. Congresso Florestal Brasileiro, Belo Horizonte, 1982 - Anais.

MACIEL, R. Sistema Simplificado para Análise de Dados Dendrométricos em Ensaios Florestais com Utilização de Microcomputador. SILVICULTURA, n.28, p.661-665, 1983. Apresentado ao 4. Congresso Florestal Brasileiro, Belo Horizonte, 1982 - Anais.

RIBEIRO, RA.S. Inventário Florestal para a Região Amazônica - INVENT. SILVICULTURA, n.28, p.690694, 1983. Apresentado ao 4. Congresso Florestal Brasileiro, Belo Horizonte, 1982 - Anais.

\section{6: 1 trabalho}

BRITES, R.S.; SOARES, V.P.; RIBEIRO, C.A.A.S. Verificação da exatidão em classificações de uma imagem orbital mediante a utilização de três índices. FLORESTA, v.20, n.3, p.415, jul./set. 1996.

\section{7: 1 trabalho}

FONTES, JM.; MACHADO, C.C.; SOUZA, A.P.de et al. Desenvolvimento de um sistema informatizado para planejamento e controle de manutenção em máquinas florestais: SIPLAM. FLORESTA, v.21, n.2, p.279288, abr.jun. 1997. 
APÊNDICE 4 - Fluxos de Caixa dos Projetos de Reflorestamento Selecionados 
Tabela 16 - Fluxo de caixa do projeto de plantio de 1 hectare de pau-marfim, em terra comprada e com a aquisição de mudas - valores expressos em reais (R\$) de março de 1999 - Projeto M1

\begin{tabular}{rrrr}
\hline Ano & Beneficios & Custos & Fluxo Líquido \\
\hline 0 & 0,00 & 2671,18 & $-2671,18$ \\
1 & 0,00 & 161,32 & $-161,32$ \\
2 & 0,00 & 66,31 & $-66,31$ \\
3 & 0,00 & 66,31 & $-66,31$ \\
4 & 0,00 & 18,63 & $-18,63$ \\
5 & 0,00 & 18,63 & $-18,63$ \\
6 & 0,00 & 18,63 & $-18,63$ \\
7 & 0,00 & 18,63 & $-18,63$ \\
8 & 0,00 & 18,63 & $-18,63$ \\
9 & 0,00 & 18,63 & $-18,63$ \\
10 & 0,00 & 18,63 & $-18,63$ \\
11 & 0,00 & 18,63 & $-18,63$ \\
12 & 63,21 & 18,63 & 44,58 \\
13 & 63,21 & 18,63 & 44,58 \\
14 & 63,21 & 18,63 & 44,58 \\
15 & 63,21 & 18,63 & 44,58 \\
16 & 0,00 & 18,63 & $-18,63$ \\
17 & 0,00 & 18,63 & $-18,63$ \\
18 & 0,00 & 18,63 & $-18,63$ \\
19 & 0,00 & 18,63 & $-18,63$ \\
20 & 667,80 & 18,63 & 649,17 \\
21 & 0,00 & 18,63 & $-18,63$ \\
22 & 0,00 & 18,63 & $-18,63$ \\
23 & 0,00 & 18,63 & $-18,63$ \\
24 & 0,00 & 18,63 & $-18,63$ \\
25 & 22624,94 & 18,63 & 22606,31 \\
\hline Fon & & & \\
\hline
\end{tabular}

Fonte: apêndice 5. 
Tabela 17 - Fluxo de caixa do projeto de plantio de 1 hectare de pau-marfim em terra arrendada e com a aquisição de mudas - valores expressos em reais (R\$) de março de 1999 - Projeto M2

\begin{tabular}{rrrr}
\hline Ano & Beneficios & Custos & Fluxo Líquido \\
\hline 0 & 0,00 & 1018,29 & $-1018,29$ \\
1 & 0,00 & 268,76 & $-268,76$ \\
2 & 0,00 & 173,75 & $-173,75$ \\
3 & 0,00 & 173,75 & $-173,75$ \\
4 & 0,00 & 126,07 & $-126,07$ \\
5 & 0,00 & 126,07 & $-126,07$ \\
6 & 0,00 & 126,07 & $-126,07$ \\
7 & 0,00 & 126,07 & $-126,07$ \\
8 & 0,00 & 126,07 & $-126,07$ \\
9 & 0,00 & 126,07 & $-126,07$ \\
10 & 0,00 & 126,07 & $-126,07$ \\
11 & 0,00 & 126,07 & $-126,07$ \\
12 & 63,21 & 126,07 & $-62,86$ \\
13 & 63,21 & 126,07 & $-62,86$ \\
14 & 63,21 & 126,07 & $-62,86$ \\
15 & 63,21 & 126,07 & $-62,86$ \\
16 & 0,00 & 126,07 & $-126,07$ \\
17 & 0,00 & 126,07 & $-126,07$ \\
18 & 0,00 & 126,07 & $-126,07$ \\
19 & 0,00 & 126,07 & $-126,07$ \\
20 & 667,80 & 126,07 & 541,73 \\
21 & 0,00 & 126,07 & $-126,07$ \\
22 & 0,00 & 126,07 & $-126,07$ \\
23 & 0,00 & 126,07 & $-126,07$ \\
24 & 0,00 & 126,07 & $-126,07$ \\
25 & 20972,05 & 126,07 & 20845,98 \\
\hline Fon & & &
\end{tabular}

Fonte: apêndice 5. 
Tabela 18 - Fluxo de caixa do projeto de plantio de 1 hectare de pau-marfim, sem considerar o custo da terra e com a aquisição de mudas - valores expressos em reais (R\$) de março de 1999 - Projeto M3

\begin{tabular}{rrrr}
\hline Ano & Benefícios & Custos & Fluxo Líquido \\
\hline 0 & 0,00 & 1018,29 & $-1018,29$ \\
1 & 0,00 & 161,32 & $-161,32$ \\
2 & 0,00 & 66,31 & $-66,31$ \\
3 & 0,00 & 66,31 & $-66,31$ \\
4 & 0,00 & 18,63 & $-18,63$ \\
5 & 0,00 & 18,63 & $-18,63$ \\
6 & 0,00 & 18,63 & $-18,63$ \\
7 & 0,00 & 18,63 & $-18,63$ \\
8 & 0,00 & 18,63 & $-18,63$ \\
9 & 0,00 & 18,63 & $-18,63$ \\
10 & 0,00 & 18,63 & $-18,63$ \\
11 & 0,00 & 18,63 & $-18,63$ \\
12 & 63,21 & 18,63 & 44,58 \\
13 & 63,21 & 18,63 & 44,58 \\
14 & 63,21 & 18,63 & 44,58 \\
15 & 63,21 & 18,63 & 44,58 \\
16 & 0,00 & 18,63 & $-18,63$ \\
17 & 0,00 & 18,63 & $-18,63$ \\
18 & 0,00 & 18,63 & $-18,63$ \\
19 & 0,00 & 18,63 & $-18,63$ \\
20 & 667,80 & 18,63 & 649,17 \\
21 & 0,00 & 18,63 & $-18,63$ \\
22 & 0,00 & 18,63 & $-18,63$ \\
23 & 0,00 & 18,63 & $-18,63$ \\
24 & 0,00 & 18,63 & $-18,63$ \\
25 & 20972,05 & 18,63 & 20953,42 \\
\hline
\end{tabular}

Fonte: apêndice 5. 
Tabela 19 - Fluxo de caixa do projeto de plantio de 1 hectare de pau-marfim em terra comprada e com mudas doadas pelo governo - valores expressos em reais (R\$) de março de 1999 - Projeto M4

\begin{tabular}{rrrr}
\hline Ano & Beneficios & Custos & Fluxo Líquido \\
\hline 0 & 0,00 & 1951,43 & $-1951,43$ \\
1 & 0,00 & 161,32 & $-161,32$ \\
2 & 0,00 & 66,31 & $-66,31$ \\
3 & 0,00 & 66,31 & $-66,31$ \\
4 & 0,00 & 18,63 & $-18,63$ \\
5 & 0,00 & 18,63 & $-18,63$ \\
6 & 0,00 & 18,63 & $-18,63$ \\
7 & 0,00 & 18,63 & $-18,63$ \\
8 & 0,00 & 18,63 & $-18,63$ \\
9 & 0,00 & 18,63 & $-18,63$ \\
10 & 0,00 & 18,63 & $-18,63$ \\
11 & 0,00 & 18,63 & $-18,63$ \\
12 & 63,21 & 18,63 & 44,58 \\
13 & 63,21 & 18,63 & 44,58 \\
14 & 63,21 & 18,63 & 44,58 \\
15 & 63,21 & 18,63 & 44,58 \\
16 & 0,00 & 18,63 & $-18,63$ \\
17 & 0,00 & 18,63 & $-18,63$ \\
18 & 0,00 & 18,63 & $-18,63$ \\
19 & 0,00 & 18,63 & $-18,63$ \\
20 & 667,80 & 18,63 & 649,17 \\
21 & 0,00 & 18,63 & $-18,63$ \\
22 & 0,00 & 18,63 & $-18,63$ \\
23 & 0,00 & 18,63 & $-18,63$ \\
24 & 0,00 & 18,63 & $-18,63$ \\
25 & 22624,94 & 18,63 & 22606,31 \\
\hline
\end{tabular}

Fonte: apêndice 5. 
Tabela 20 - Fluxo de caixa do projeto de plantio de 1 hectare de pau-marfim em terra arrendada e com mudas doadas pelo governo - valores expressos em reais (R\$) de março de 1999 - Projeto M5

\begin{tabular}{rrrr}
\hline Ano & Beneficios & Custos & Fluxo Líquido \\
\hline 0 & 0,00 & 298,54 & $-298,54$ \\
1 & 0,00 & 268,76 & $-268,76$ \\
2 & 0,00 & 173,75 & $-173,75$ \\
3 & 0,00 & 173,75 & $-173,75$ \\
4 & 0,00 & 126,07 & $-126,07$ \\
5 & 0,00 & 126,07 & $-126,07$ \\
6 & 0,00 & 126,07 & $-126,07$ \\
7 & 0,00 & 126,07 & $-126,07$ \\
8 & 0,00 & 126,07 & $-126,07$ \\
9 & 0,00 & 126,07 & $-126,07$ \\
10 & 0,00 & 126,07 & $-126,07$ \\
11 & 0,00 & 126,07 & $-126,07$ \\
12 & 63,21 & 126,07 & $-62,86$ \\
13 & 63,21 & 126,07 & $-62,86$ \\
14 & 63,21 & 126,07 & $-62,86$ \\
15 & 63,21 & 126,07 & $-62,86$ \\
16 & 0,00 & 126,07 & $-126,07$ \\
17 & 0,00 & 126,07 & $-126,07$ \\
18 & 0,00 & 126,07 & $-126,07$ \\
19 & 0,00 & 126,07 & $-126,07$ \\
20 & 667,80 & 126,07 & 541,73 \\
21 & 0,00 & 126,07 & $-126,07$ \\
22 & 0,00 & 126,07 & $-126,07$ \\
23 & 0,00 & 126,07 & $-126,07$ \\
24 & 0,00 & 126,07 & $-126,07$ \\
25 & 20972,05 & 126,07 & 20845,98 \\
\hline
\end{tabular}

Fonte: apêndice 5 . 
Tabela 21 - Fluxo de caixa do projeto de plantio de 1 hectare de pau-marfim sem considerar o custo da terra e com mudas doadas pelo governo - valores expressos em reais (R\$) de março de 1999 - Projeto M6

\begin{tabular}{rrrr}
\hline Ano & Beneficios & Custos & Fluxo Líquido \\
\hline 0 & 0,00 & 298,54 & $-298,54$ \\
1 & 0,00 & 161,32 & $-161,32$ \\
2 & 0,00 & 66,31 & $-66,31$ \\
3 & 0,00 & 66,31 & $-66,31$ \\
4 & 0,00 & 18,63 & $-18,63$ \\
5 & 0,00 & 18,63 & $-18,63$ \\
6 & 0,00 & 18,63 & $-18,63$ \\
7 & 0,00 & 18,63 & $-18,63$ \\
8 & 0,00 & 18,63 & $-18,63$ \\
9 & 0,00 & 18,63 & $-18,63$ \\
10 & 0,00 & 18,63 & $-18,63$ \\
11 & 0,00 & 18,63 & $-18,63$ \\
12 & 63,21 & 18,63 & 44,58 \\
13 & 63,21 & 18,63 & 44,58 \\
14 & 63,21 & 18,63 & 44,58 \\
15 & 63,21 & 18,63 & 44,58 \\
16 & 0,00 & 18,63 & $-18,63$ \\
17 & 0,00 & 18,63 & $-18,63$ \\
18 & 0,00 & 18,63 & $-18,63$ \\
19 & 0,00 & 18,63 & $-18,63$ \\
20 & 667,80 & 18,63 & 649,17 \\
21 & 0,00 & 18,63 & $-18,63$ \\
22 & 0,00 & 18,63 & $-18,63$ \\
23 & 0,00 & 18,63 & $-18,63$ \\
24 & 0,00 & 18,63 & $-18,63$ \\
25 & 20972,05 & 18,63 & 20953,42 \\
\hline Fon & & &
\end{tabular}

Fonte: apêndice 5. 
Tabela 22 - Fluxo de caixa do projeto de plantio de 1 hectare de pinheiro-brasileiro, em terra comprada e com aquisição de mudas - valores expressos em reais (R\$) de março de 1999 - Projeto P1

\begin{tabular}{rrrr}
\hline Ano & Beneficios & Custos & Fluxo Líquido \\
\hline 0 & 0,00 & 2357,21 & $-2357,21$ \\
1 & 0,00 & 161,32 & $-161,32$ \\
2 & 0,00 & 66,31 & $-66,31$ \\
3 & 0,00 & 66,31 & $-66,31$ \\
4 & 0,00 & 18,63 & $-18,63$ \\
5 & 0,00 & 18,63 & $-18,63$ \\
6 & 13,02 & 18,63 & $-5,61$ \\
7 & 0,00 & 18,63 & $-18,63$ \\
8 & 0,00 & 18,63 & $-18,63$ \\
9 & 0,00 & 18,63 & $-18,63$ \\
10 & 13,02 & 18,63 & $-5,61$ \\
11 & 0,00 & 18,63 & $-18,63$ \\
12 & 13,02 & 18,63 & $-5,61$ \\
13 & 0,00 & 18,63 & $-18,63$ \\
14 & 0,00 & 18,63 & $-18,63$ \\
15 & 0,00 & 18,63 & $-18,63$ \\
16 & 0,00 & 18,63 & $-18,63$ \\
17 & 0,00 & 18,63 & $-18,63$ \\
18 & 0,00 & 18,63 & $-18,63$ \\
19 & 0,00 & 18,63 & $-18,63$ \\
20 & 0,00 & 18,63 & $-18,63$ \\
21 & 635,00 & 18,63 & $-616,37$ \\
22 & 0,00 & 18,63 & $-18,63$ \\
23 & 0,00 & 18,63 & $-18,63$ \\
24 & 0,00 & 18,63 & $-18,63$ \\
25 & 25560,55 & 18,63 & 25541,92 \\
\hline
\end{tabular}

Fonte: apêndice 6. 
Tabela 23 - Fluxo de caixa do projeto de plantio de 1 hectare de pinheiro-brasileiro em terra arrendada e com aquisição de mudas - valores expressos em reais (R\$) de março de 1999 - Projeto P2

\begin{tabular}{rrrr}
\hline Ano & Beneficios & Custos & Fluxo Líquido \\
\hline 0 & 0,00 & 704,32 & $-704,32$ \\
1 & 0,00 & 268,76 & $-268,76$ \\
2 & 0,00 & 173,75 & $-173,75$ \\
3 & 0,00 & 173,75 & $-173,75$ \\
4 & 0,00 & 126,07 & $-126,07$ \\
5 & 0,00 & 126,07 & $-126,07$ \\
6 & 13,02 & 126,07 & $-113,05$ \\
7 & 0,00 & 126,07 & $-126,07$ \\
8 & 0,00 & 126,07 & $-126,07$ \\
9 & 0,00 & 126,07 & $-126,07$ \\
10 & 13,02 & 126,07 & $-113,05$ \\
11 & 0,00 & 126,07 & $-126,07$ \\
12 & 13,02 & 126,07 & $-113,05$ \\
13 & 0,00 & 126,07 & $-126,07$ \\
14 & 0,00 & 126,07 & $-126,07$ \\
15 & 0,00 & 126,07 & $-126,07$ \\
16 & 0,00 & 126,07 & $-126,07$ \\
17 & 0,00 & 126,07 & $-126,07$ \\
18 & 0,00 & 126,07 & $-126,07$ \\
19 & 0,00 & 126,07 & $-126,07$ \\
20 & 0,00 & 126,07 & $-126,07$ \\
21 & 635,00 & 126,07 & 508,93 \\
22 & 0,00 & 126,07 & $-126,07$ \\
23 & 0,00 & 126,07 & $-126,07$ \\
24 & 0,00 & 126,07 & $-126,07$ \\
25 & 23907,66 & 126,07 & 23781,59 \\
\hline
\end{tabular}

Fonte: apêndice 6. 
Tabela 24 - Fluxo de caixa do projeto de plantio de 1 hectare de pinheiro-brasileiro, sem considerar o custo da terra e com aquisição de mudas - valores expressos em reais (R\$) de março de 1999 - Projeto P3

\begin{tabular}{rrrr}
\hline Ano & Beneficios & Custos & Fluxo Líquido \\
\hline 0 & 0,00 & 704,32 & $-704,32$ \\
1 & 0,00 & 161,32 & $-161,32$ \\
2 & 0,00 & 66,31 & $-66,31$ \\
3 & 0,00 & 66,31 & $-66,31$ \\
4 & 0,00 & 18,63 & $-18,63$ \\
5 & 0,00 & 18,63 & $-18,63$ \\
6 & 13,02 & 18,63 & $-5,61$ \\
7 & 0,00 & 18,63 & $-18,63$ \\
8 & 0,00 & 18,63 & $-18,63$ \\
9 & 0,00 & 18,63 & $-18,63$ \\
10 & 13,02 & 18,63 & $-5,61$ \\
11 & 0,00 & 18,63 & $-18,63$ \\
12 & 13,02 & 18,63 & $-5,61$ \\
13 & 0,00 & 18,63 & $-18,63$ \\
14 & 0,00 & 18,63 & $-18,63$ \\
15 & 0,00 & 18,63 & $-18,63$ \\
16 & 0,00 & 18,63 & $-18,63$ \\
17 & 0,00 & 18,63 & $-18,63$ \\
18 & 0,00 & 18,63 & $-18,63$ \\
19 & 0,00 & 18,63 & $-18,63$ \\
20 & 0,00 & 18,63 & $-18,63$ \\
21 & 635,00 & 18,63 & $-616,37$ \\
22 & 0,00 & 18,63 & $-18,63$ \\
23 & 0,00 & 18,63 & $-18,63$ \\
24 & 0,00 & 18,63 & $-18,63$ \\
25 & 23907,66 & 18,63 & 23889,03 \\
\hline
\end{tabular}

Fonte: apêndice 6 . 
Tabela 25 - Fluxo de caixa do projeto de plantio de 1 hectare de pinheiro-brasileiro em terra comprada e com mudas doadas pelo governo - valores expressos em reais (R\$) de março de 1999 - Projeto P4

\begin{tabular}{rrrr}
\hline Ano & Beneficios & Custos & Fluxo Líquido \\
\hline 0 & 0,00 & 1951,43 & $-1951,43$ \\
1 & 0,00 & 161,32 & $-161,32$ \\
2 & 0,00 & 66,31 & $-66,31$ \\
3 & 0,00 & 66,31 & $-66,31$ \\
4 & 0,00 & 18,63 & $-18,63$ \\
5 & 0,00 & 18,63 & $-18,63$ \\
6 & 13,02 & 18,63 & $-5,61$ \\
7 & 0,00 & 18,63 & $-18,63$ \\
8 & 0,00 & 18,63 & $-18,63$ \\
9 & 0,00 & 18,63 & $-18,63$ \\
10 & 13,02 & 18,63 & $-5,61$ \\
11 & 0,00 & 18,63 & $-18,63$ \\
12 & 13,02 & 18,63 & $-5,61$ \\
13 & 0,00 & 18,63 & $-18,63$ \\
14 & 0,00 & 18,63 & $-18,63$ \\
15 & 0,00 & 18,63 & $-18,63$ \\
16 & 0,00 & 18,63 & $-18,63$ \\
17 & 0,00 & 18,63 & $-18,63$ \\
18 & 0,00 & 18,63 & $-18,63$ \\
19 & 0,00 & 18,63 & $-18,63$ \\
20 & 0,00 & 18,63 & $-18,63$ \\
21 & 635,00 & 18,63 & $-616,37$ \\
22 & 0,00 & 18,63 & $-18,63$ \\
23 & 0,00 & 18,63 & $-18,63$ \\
24 & 0,00 & 18,63 & $-18,63$ \\
25 & 25560,55 & 18,63 & 25541,92 \\
\hline
\end{tabular}

Fonte: apêndice 6. 
Tabela 26 - Fluxo de caixa do projeto de plantio de 1 hectare de pinheiro-brasileiro em terra arrendada e com mudas doadas pelo governo - valores expressos em reais (R\$) de março de 1999 - Projeto P5

\begin{tabular}{rrrr}
\hline Ano & Beneficios & Custos & Fluxo Líquido \\
\hline 0 & 0,00 & 298,54 & $-298,54$ \\
1 & 0,00 & 268,76 & $-268,76$ \\
2 & 0,00 & 173,75 & $-173,75$ \\
3 & 0,00 & 173,75 & $-173,75$ \\
4 & 0,00 & 126,07 & $-126,07$ \\
5 & 0,00 & 126,07 & $-126,07$ \\
6 & 13,02 & 126,07 & $-113,05$ \\
7 & 0,00 & 126,07 & $-126,07$ \\
8 & 0,00 & 126,07 & $-126,07$ \\
9 & 0,00 & 126,07 & $-126,07$ \\
10 & 13,02 & 126,07 & $-113,05$ \\
11 & 0,00 & 126,07 & $-126,07$ \\
12 & 13,02 & 126,07 & $-113,05$ \\
13 & 0,00 & 126,07 & $-126,07$ \\
14 & 0,00 & 126,07 & $-126,07$ \\
15 & 0,00 & 126,07 & $-126,07$ \\
16 & 0,00 & 126,07 & $-126,07$ \\
17 & 0,00 & 126,07 & $-126,07$ \\
18 & 0,00 & 126,07 & $-126,07$ \\
19 & 0,00 & 126,07 & $-126,07$ \\
20 & 0,00 & 126,07 & $-126,07$ \\
21 & 635,00 & 126,07 & 508,93 \\
22 & 0,00 & 126,07 & $-126,07$ \\
23 & 0,00 & 126,07 & $-126,07$ \\
24 & 0,00 & 126,07 & $-126,07$ \\
25 & 23907,66 & 126,07 & 23781,59 \\
\hline
\end{tabular}

Fonte: apêndice 6 . 
Tabela 27 - Fluxo de caixa do projeto de plantio de 1 hectare de pinheiro-brasileiro, sem considerar o custo da terra e com mudas doadas pelo governo - valores expressos em reais (R\$) de março de 1999 - Projeto P6

\begin{tabular}{rrrr}
\hline Ano & Beneficios & Custos & Fluxo Líquido \\
\hline 0 & 0,00 & 298,54 & $-298,54$ \\
1 & 0,00 & 161,32 & $-161,32$ \\
2 & 0,00 & 66,31 & $-66,31$ \\
3 & 0,00 & 66,31 & $-66,31$ \\
4 & 0,00 & 18,63 & $-18,63$ \\
5 & 0,00 & 18,63 & $-18,63$ \\
6 & 13,02 & 18,63 & $-5,61$ \\
7 & 0,00 & 18,63 & $-18,63$ \\
8 & 0,00 & 18,63 & $-18,63$ \\
9 & 0,00 & 18,63 & $-18,63$ \\
10 & 13,02 & 18,63 & $-5,61$ \\
11 & 0,00 & 18,63 & $-18,63$ \\
12 & 13,02 & 18,63 & $-5,61$ \\
13 & 0,00 & 18,63 & $-18,63$ \\
14 & 0,00 & 18,63 & $-18,63$ \\
15 & 0,00 & 18,63 & $-18,63$ \\
16 & 0,00 & 18,63 & $-18,63$ \\
17 & 0,00 & 18,63 & $-18,63$ \\
18 & 0,00 & 18,63 & $-18,63$ \\
19 & 0,00 & 18,63 & $-18,63$ \\
20 & 0,00 & 18,63 & $-18,63$ \\
21 & 635,00 & 18,63 & $-616,37$ \\
22 & 0,00 & 18,63 & $-18,63$ \\
23 & 0,00 & 18,63 & $-18,63$ \\
24 & 0,00 & 18,63 & $-18,63$ \\
25 & 23907,66 & 18,63 & 23889,03 \\
\hline
\end{tabular}

Fonte: apêndice 6. 
Tabela 28 - Fluxo de caixa do projeto de plantio de 1 hectare de araruva em terra comprada e com aquisição de mudas - valores expressos em reais (R\$) de março de 1999 - Projeto A1

\begin{tabular}{rrrr}
\hline Ano & Beneficios & Custos & Fluxo Líquido \\
\hline 0 & 0,00 & 2863,89 & $-2863,89$ \\
1 & 0,00 & 161,32 & $-161,32$ \\
2 & 0,00 & 66,31 & $-66,31$ \\
3 & 0,00 & 66,31 & $-66,31$ \\
4 & 0,00 & 18,63 & $-18,63$ \\
5 & 0,00 & 18,63 & $-18,63$ \\
6 & 0,00 & 18,63 & $-18,63$ \\
7 & 0,00 & 18,63 & $-18,63$ \\
8 & 0,00 & 18,63 & $-18,63$ \\
9 & 0,00 & 18,63 & $-18,63$ \\
10 & 12,00 & 18,63 & $-6,63$ \\
11 & 30,00 & 18,63 & 11,37 \\
12 & 15,00 & 18,63 & $-3,63$ \\
13 & 18,00 & 18,63 & $-0,63$ \\
14 & 54,57 & 18,63 & 35,94 \\
15 & 0,00 & 18,63 & $-18,63$ \\
16 & 753,00 & 18,63 & 734,37 \\
17 & 0,00 & 18,63 & $-18,63$ \\
18 & 0,00 & 18,63 & $-18,63$ \\
19 & 0,00 & 18,63 & $-18,63$ \\
20 & 0,00 & 18,63 & $-18,63$ \\
21 & 0,00 & 18,63 & $-18,63$ \\
22 & 0,00 & 18,63 & $-18,63$ \\
23 & 0,00 & 18,63 & $-18,63$ \\
24 & 0,00 & 18,63 & $-18,63$ \\
25 & 33703,94 & 18,63 & 33685,31 \\
\hline
\end{tabular}

Fonte: apêndice 7. 
Tabela 29 - Fluxo de caixa do projeto de plantio de 1 hectare de araruva em terra arrendada e com aquisição de mudas - valores expressos em reais (R\$) de março de 1999 - Projeto A2

\begin{tabular}{rrrr}
\hline Ano & Beneficios & Custos & Fluxo Líquido \\
\hline 0 & 0,00 & 1211,00 & $-1211,00$ \\
1 & 0,00 & 268,76 & $-268,76$ \\
2 & 0,00 & 173,75 & $-173,75$ \\
3 & 0,00 & 173,75 & $-173,75$ \\
4 & 0,00 & 126,07 & $-126,07$ \\
5 & 0,00 & 126,07 & $-126,07$ \\
6 & 0,00 & 126,07 & $-126,07$ \\
7 & 0,00 & 126,07 & $-126,07$ \\
8 & 0,00 & 126,07 & $-126,07$ \\
9 & 0,00 & 126,07 & $-126,07$ \\
10 & 12,00 & 126,07 & $-114,07$ \\
11 & 30,00 & 126,07 & $-96,07$ \\
12 & 15,00 & 126,07 & $-111,07$ \\
13 & 18,00 & 126,07 & $-108,07$ \\
14 & 54,57 & 126,07 & $-71,50$ \\
15 & 0,00 & 126,07 & $-126,07$ \\
16 & 753,00 & 126,07 & $-626,93$ \\
17 & 0,00 & 126,07 & $-126,07$ \\
18 & 0,00 & 126,07 & $-126,07$ \\
19 & 0,00 & 126,07 & $-126,07$ \\
20 & 0,00 & 126,07 & $-126,07$ \\
21 & 0,00 & 126,07 & $-126,07$ \\
22 & 0,00 & 126,07 & $-126,07$ \\
23 & 0,00 & 126,07 & $-126,07$ \\
24 & 0,00 & 126,07 & $-126,07$ \\
25 & 32051,05 & 126,07 & 31924,98 \\
\hline
\end{tabular}

Fonte: apêndice 7 . 
Tabela 30 - Fluxo de caixa do projeto de plantio de 1 hectare de araruva, sem considerar o custo da terra e com a aquisição de mudas - valores expressos em reais (R\$) de março de 1999 - Projeto A3

\begin{tabular}{rrrr}
\hline Ano & Beneficios & Custos & Fluxo Líquido \\
\hline 0 & 0,00 & 1211,00 & $-1211,00$ \\
1 & 0,00 & 161,32 & $-161,32$ \\
2 & 0,00 & 66,31 & $-66,31$ \\
3 & 0,00 & 66,31 & $-66,31$ \\
4 & 0,00 & 18,63 & $-18,63$ \\
5 & 0,00 & 18,63 & $-18,63$ \\
6 & 0,00 & 18,63 & $-18,63$ \\
7 & 0,00 & 18,63 & $-18,63$ \\
8 & 0,00 & 18,63 & $-18,63$ \\
9 & 0,00 & 18,63 & $-18,63$ \\
10 & 12,00 & 18,63 & $-6,63$ \\
11 & 30,00 & 18,63 & 11,27 \\
12 & 15,00 & 18,63 & $-3,63$ \\
13 & 18,00 & 18,63 & $-0,63$ \\
14 & 54,57 & 18,63 & 35,94 \\
15 & 0,00 & 18,63 & $-18,63$ \\
16 & 753,00 & 18,63 & 734,37 \\
17 & 0,00 & 18,63 & $-18,63$ \\
18 & 0,00 & 18,63 & $-18,63$ \\
19 & 0,00 & 18,63 & $-18,63$ \\
20 & 0,00 & 18,63 & $-18,63$ \\
21 & 0,00 & 18,63 & $-18,63$ \\
22 & 0,00 & 18,63 & $-18,63$ \\
23 & 0,00 & 18,63 & $-18,63$ \\
24 & 0,00 & 18,63 & $-18,63$ \\
25 & 32051,05 & 18,63 & 32032,42 \\
\hline Fon & &
\end{tabular}

Fonte: apêndice 7. 
Tabela 31 - Fluxo de caixa do projeto de plantio de 1 hectare de pau-marfim, em terra comprada e com mudas doadas pelo governo - valores expressos em reais $(\mathrm{R} \$$ ) de março de 1999 - Projeto A4

\begin{tabular}{rrrr}
\hline Ano & Beneficios & Custos & Fluxo Líquido \\
\hline 0 & 0,00 & 1865,50 & $-1865,50$ \\
1 & 0,00 & 161,32 & $-161,32$ \\
2 & 0,00 & 66,31 & $-66,31$ \\
3 & 0,00 & 66,31 & $-66,31$ \\
4 & 0,00 & 18,63 & $-18,63$ \\
5 & 0,00 & 18,63 & $-18,63$ \\
6 & 0,00 & 18,63 & $-18,63$ \\
7 & 0,00 & 18,63 & $-18,63$ \\
8 & 0,00 & 18,63 & $-18,63$ \\
9 & 0,00 & 18,63 & $-18,63$ \\
10 & 12,00 & 18,63 & $-6,63$ \\
11 & 30,00 & 18,63 & 11,37 \\
12 & 15,00 & 18,63 & $-3,63$ \\
13 & 18,00 & 18,63 & $-0,63$ \\
14 & 54,57 & 18,63 & 35,94 \\
15 & 0,00 & 18,63 & $-18,63$ \\
16 & 753,00 & 18,63 & 734,37 \\
17 & 0,00 & 18,63 & $-18,63$ \\
18 & 0,00 & 18,63 & $-18,63$ \\
19 & 0,00 & 18,63 & $-18,63$ \\
20 & 0,00 & 18,63 & $-18,63$ \\
21 & 0,00 & 18,63 & $-18,63$ \\
22 & 0,00 & 18,63 & $-18,63$ \\
23 & 0,00 & 18,63 & $-18,63$ \\
24 & 0,00 & 18,63 & $-18,63$ \\
25 & 33703,94 & 18,63 & 33685,31 \\
\hline Fon & & & \\
\hline
\end{tabular}

Fonte: apêndice 7 . 
Tabela 32 - Fluxo de caixa do projeto de plantio de 1 hectare de araruva em terra arrendada e com mudas doadas pelo governo - valores expressos em reais (R\$) de março de 1999 - Projeto A5

\begin{tabular}{rrrr}
\hline Ano & Beneficios & Custos & Fluxo Líquido \\
\hline 0 & 0,00 & 213,61 & $-213,61$ \\
1 & 0,00 & 268,76 & $-268,76$ \\
2 & 0,00 & 173,75 & $-173,75$ \\
3 & 0,00 & 173,75 & $-173,75$ \\
4 & 0,00 & 126,07 & $-126,07$ \\
5 & 0,00 & 126,07 & $-126,07$ \\
6 & 0,00 & 126,07 & $-126,07$ \\
7 & 0,00 & 126,07 & $-126,07$ \\
8 & 0,00 & 126,07 & $-126,07$ \\
9 & 0,00 & 126,07 & $-126,07$ \\
10 & 12,00 & 126,07 & $-114,07$ \\
11 & 30,00 & 126,07 & $-96,07$ \\
12 & 15,00 & 126,07 & $-111,07$ \\
13 & 18,00 & 126,07 & $-108,07$ \\
14 & 54,57 & 126,07 & $-71,50$ \\
15 & 0,00 & 126,07 & $-126,07$ \\
16 & 753,00 & 126,07 & $-626,93$ \\
17 & 0,00 & 126,07 & $-126,07$ \\
18 & 0,00 & 126,07 & $-126,07$ \\
19 & 0,00 & 126,07 & $-126,07$ \\
20 & 0,00 & 126,07 & $-126,07$ \\
21 & 0,00 & 126,07 & $-126,07$ \\
22 & 0,00 & 126,07 & $-126,07$ \\
23 & 0,00 & 126,07 & $-126,07$ \\
24 & 0,00 & 126,07 & $-126,07$ \\
25 & 32051,05 & 126,07 & 31924,98 \\
\hline
\end{tabular}

Fonte: apêndice 7 . 
Tabela 33 - Fluxo de caixa do projeto de plantio de 1 hectare de araruva, sem considerar o custo da terra e com mudas doadas pelo governo - valores expressos em reais (R\$) de março de 1999 - Projeto A6

\begin{tabular}{rrrr}
\hline Ano & Beneficios & Custos & Fluxo Líquido \\
\hline 0 & 0,00 & 213,61 & $-213,61$ \\
1 & 0,00 & 161,32 & $-161,32$ \\
2 & 0,00 & 66,31 & $-66,31$ \\
3 & 0,00 & 66,31 & $-66,31$ \\
4 & 0,00 & 18,63 & $-18,63$ \\
5 & 0,00 & 18,63 & $-18,63$ \\
6 & 0,00 & 18,63 & $-18,63$ \\
7 & 0,00 & 18,63 & $-18,63$ \\
8 & 0,00 & 18,63 & $-18,63$ \\
9 & 0,00 & 18,63 & $-18,63$ \\
10 & 12,00 & 18,63 & $-6,63$ \\
11 & 30,00 & 18,63 & 11,27 \\
12 & 15,00 & 18,63 & $-3,63$ \\
13 & 18,00 & 18,63 & $-0,63$ \\
14 & 54,57 & 18,63 & 35,94 \\
15 & 0,00 & 18,63 & $-18,63$ \\
16 & 753,00 & 18,63 & 734,37 \\
17 & 0,00 & 18,63 & $-18,63$ \\
18 & 0,00 & 18,63 & $-18,63$ \\
19 & 0,00 & 18,63 & $-18,63$ \\
20 & 0,00 & 18,63 & $-18,63$ \\
21 & 0,00 & 18,63 & $-18,63$ \\
22 & 0,00 & 18,63 & $-18,63$ \\
23 & 0,00 & 18,63 & $-18,63$ \\
24 & 0,00 & 18,63 & $-18,63$ \\
25 & 32051,05 & 18,63 & 32032,42 \\
\hline
\end{tabular}

Fonte: apêndice 7 . 
Apêndice 5 - Informações gerais sobre os benefícios e custos do reflorestamento com o pau-marfim (Balfourodendron riedelianum). 
- Quantidades e preços dos produtos e subprodutos da exploração florestal

Os dados de produção do pau-marfim, utilizados para os projetos M1, M2, M3, M4, M5 e M6, são baseados nos resultados obtidos do Projeto 16/54-SR, instalado na Estação Experimental de Santa Rita do Passa Quatro, do Instituto Florestal, sob espaçamento $2,0 \times 2,0$ metros, em 1954. Segundo Gurgel Filho et al.(1978), nas condições do experimento, o incremento volumétrico anual é de 11,601 metros cúbicos por hectare $\left(\mathrm{m}^{3} / \mathrm{ha}\right)$. No $20^{0}$ ano foi realizado o $5^{0}$ desbaste do qual se obteve $33,391 \mathrm{~m}^{3}$ de madeira por hectare. Conforme os históricos dos experimentos, os desbastes anteriores ocorreram no $12^{\underline{0}}, 13^{0}, 14^{0}$ e $15^{0}$ anos, respectivamente. $O$ volume de madeira desses anos é calculado assim:

$V_{i}=\left(V_{20}-V_{20}\right) / 4=(11,601 \times 20-147,727) / 4=21,07325$

Onde:

$V_{i}=$ volume anual desbastado no ano $i$, onde $i=12,13,14$ ou 15

$\mathrm{VT}_{20}=$ volume total aos 20 anos, sem desbaste, $\mathrm{em} \mathrm{m}^{3} / \mathrm{ha}$

$\mathrm{VP}_{20}=$ volume presente aos 20 anos, após 4 desbastes, em $\mathrm{m}^{3} / \mathrm{ha}$

$\mathrm{VD}_{20}=$ volume desbastado aos 20 anos, $\mathrm{em} \mathrm{m}^{3} / \mathrm{ha}$

O volume previsto para o $25^{0}$ ano é calculado assim:

$\mathrm{V}_{25}=\mathrm{VP}_{20}-\mathrm{VD}_{20}+5 \mathrm{xIVA}=114,336+5 \times 11,601=172,341$

Onde:

$\mathrm{V}_{25}=$ volume esperado para o $25^{0}$ ano, $\mathrm{em} \mathrm{m}^{3} / \mathrm{ha}$

$\mathrm{VD}_{20}=$ volume desbastado no $20^{\circ}$ ano, $\mathrm{em} \mathrm{m}^{3} / \mathrm{ha}$

IVA $=$ incremento volumétrico anual, $\mathrm{em}^{3} / \mathrm{ha}$

Os preços dos subprodutos (lenha, repique e moirão) foram levantados junto às serrarias da região, em março de 1999. A lenha foi cotada a $R \$ 3,00 / \mathrm{m}^{3}$ e a madeira para repique e moirão foi cotada a $\mathrm{R} \$ 20,00 / \mathrm{m}^{3}$. O preço do principal produto do reflorestamento - as toras para o desdobro mecânico - foi obtido da seguinte forma:

a) Distância do municipio de Sinop-MT a Santa Rita do Passa Quatro-SP: A=1861 km (fonte: Guia Quatro Rodas. Brasil, 1999.)

b) Frete rodoviário para transporte da madeira (toretes): $B=R \$ 0,0437 / \mathrm{t} . \mathrm{km}$ (fonte: INFORME SIFRECA - ano 3 - no 23 - março 1999). Frete relativo ao percurso de $410 \mathrm{~km}$ entre Itararé (SP) e Suzano (SP).

c) Densidade da madeira do pau-marfim: $C=0,84 \mathrm{~g} / \mathrm{cm}^{3}$ (Lorenzi, 1992). 
d) Cálculo do frete de $1 \mathrm{~m}^{3}$ de toras de pau-marfim de Sinop-MT a Santa Rita do Passa Quatro: D = A $\times$ B $\times$ C $=1861 \mathrm{~km} \times \mathrm{R} \$ 0,0437 / \mathrm{t} . \mathrm{km} \times 0,84 \mathrm{t} / \mathrm{m}^{3}=\mathrm{R} \$ 68,31 / \mathrm{m}^{3}$

e) Cálculo do preço médio da madeira em tora na serraria, na região Norte, em janeiro ${ }^{1}$ de 1999 (fonte: http://www.itto.jp.or)

Espécie: jatobá $\square$ U\$ $45,00 / \mathrm{m}^{3}$ e ipê $\square$ U\$ $68,00 / \mathrm{m}^{3}$

Preço Médio: $E=U \$ 56,50 / \mathrm{m}^{3}$ ou $R \$ 68,38 / \mathrm{m}^{3}$ ( U $\$ 1,00=\mathrm{R} \$ 1,2103$ )

f) Cálculo do preço da madeira em tora na serraria em Santa Rita do Passa Quatro $\mathrm{F}=\mathrm{D}+\mathrm{E}=\mathrm{R} \$ 68,38 / \mathrm{m}^{3}+\mathrm{R} \$ 68,31 / \mathrm{m}^{3}=\mathrm{R} \$ 136,69 / \mathrm{m}^{3}$

g) Custo da exploração de madeira em toras:

Segundo empresas da região, o custo do corte e transporte da madeira do campo até a serraria, em março de 1999 era de $\mathrm{R} \$ 15,00 / \mathrm{m}^{3}$

h) Cálculo do preço da madeira em pé na região de Santa Rita do Passa Quatro $\mathrm{H}=\mathrm{F}-\mathrm{G}=\mathrm{R} \$ 136,69-\mathrm{R} \$ 15,00=\mathrm{R} \$ 121,69$

1. Projeto M1 - Plantio do pau-marfim em terra comprada e com a aquisição de mudas

\section{1 - Benefícios}

1.1.1 - Receita da venda da terra no final do projeto

O preço praticado na região para o tipo de solo utilizado no experimento foi cotado a R $\$ 1652,89$ por hectare, segundo levantamento feito por técnicos da Estação Experimental de Santa Rita do Passa Quatro, do Instituto Florestal, em março de 1999.

1.1.2 - Receitas das vendas dos subprodutos e produtos da exploração florestal

Tabela 34 - Receitas das vendas dos subprodutos e produtos da exploração florestal de 1 ha de pau-marfim

\begin{tabular}{c|c|c|c}
\hline $\begin{array}{c}\text { Idade } \\
\text { (anos) }\end{array}$ & $\begin{array}{c}\text { Volume Retirado } \\
\left(\mathrm{m}^{3} / \mathrm{ha}\right)\end{array}$ & $\begin{array}{c}\text { Preço Unitário } \\
\left(\mathrm{R} \$ / \mathrm{m}^{3}\right)\end{array}$ & $\begin{array}{c}\text { Receita Total } \\
(\mathrm{R} \$)\end{array}$ \\
\hline 12 & 21,07 & 3,00 & 63,21 \\
13 & 21,07 & 3,00 & 63,21 \\
14 & 21,07 & 3,00 & 63,21 \\
15 & 21,07 & 3,00 & 63,21 \\
20 & 33,39 & 20,00 & 667,80 \\
25 & 172,34 & 121,69 & 20972,05 \\
\hline
\end{tabular}

Fonte: Gurgel Filho et al.(1978); dados de pesquisa; e, valores calculados pelo autor.

\footnotetext{
${ }^{1}$ Optou-se por trabalhar com o preço em reais de janeiro de 1999 pelo fato de haver indícios do mesmo ter se mantido até abril do corrente ano.
} 


\section{2 - Custos}

1.2.1 - Investimento Inicial (ano 0)

1.2.1.1 - Compra da terra: idem do item 1.1.1

1.2.1.2 - Custo de Implantação

Tabela 35 - Custo de Implantação de 1 hectare de pau-marfim com aquisição das mudas

\begin{tabular}{l|c|c|c|c}
\hline \multicolumn{1}{c|}{ Item } & Unidade & Quantidade & $\begin{array}{c}\text { Preço Unitário } \\
\text { (R\$) }\end{array}$ & $\begin{array}{c}\text { Valor Total } \\
\text { (R\$) }\end{array}$ \\
\hline 1. Operações & Horas & 2,5 & 8,45 & 21,13 \\
Aração & Horas & 2,5 & 8,45 & 21,13 \\
Gradeação & Horas & 52,0 & 1,49 & 77,48 \\
Balizamento & Horas & 60,0 & 1,49 & 89,40 \\
Coveamento & Horas & 60,0 & 1,49 & 89,40 \\
Plantio & & & & \\
2. Materiais & Mil & 2,5 & 287,90 & 719,75 \\
Mudas & & & & 1018,29 \\
TOTAL & & & & \\
\hline
\end{tabular}

Fonte: Gurgel Filho (1978); Instituto Florestal; e, dados de pesquisa

\subsection{2 - Custos Anuais de Manutenção}

Tabela 36 - Custo de Manutenção no $1^{0}$ ano de 1 ha plantado com pau-marfim

\begin{tabular}{l|c|c|c|c}
\hline Item & Unidade & Quantidade & $\begin{array}{c}\text { Preço Unitário } \\
\text { (R\$) }\end{array}$ & $\begin{array}{c}\text { Valor Total } \\
\text { (R\$) }\end{array}$ \\
\hline $\begin{array}{l}\text { l. Operações } \\
\text { Trilhação }\end{array}$ & Horas & 24,0 & 1,49 & 35,76 \\
$\begin{array}{l}\text { Limpeza } \\
\text { aceiros }\end{array}$ & Horas & 1,0 & 8,45 & 8,45 \\
$\begin{array}{l}\text { Combate } \\
\text { formiga }\end{array}$ & Horas & 19,0 & 1,49 & 28,31 \\
& & & & \\
2. Materiais & & & & \\
Formicida em pó & $\mathrm{Kg}$ & 3,5 & 4,80 & 16,80 \\
Isca Granulada & $\mathrm{Kg}$ & 10,0 & 7,20 & 72,00 \\
TOTAL & & & & 161,32 \\
\hline
\end{tabular}

Fonte: Gurgel Filho et al. (1978); Instituto Florestal; e, dados de pesquisa 
Tabela 37 - Custo Anual de Manutenção do $2^{\underline{0}}$ ao $3^{\mathrm{o}}$ ano de 1 ha plantado com pau-marfim

\begin{tabular}{|c|c|c|c|c|c|}
\hline Item & & Unidade & Quantidade & $\begin{array}{l}\text { Preço Unitário } \\
\text { (R\$) }\end{array}$ & $\begin{array}{l}\text { Valor Total } \\
\text { (RS) }\end{array}$ \\
\hline 1. Operações & & & & & \\
\hline Trilhação & & Horas & 32,0 & 1,49 & 47,68 \\
\hline $\begin{array}{l}\text { Limpeza } \\
\text { aceiros }\end{array}$ & de & Horas & 1,0 & 8,45 & 8,45 \\
\hline $\begin{array}{l}\text { Combate } \\
\text { formiga }\end{array}$ & a & Horas & 2,0 & 1,49 & 2,98 \\
\hline $\begin{array}{l}\text { 2. Materiais } \\
\text { Isca Granulada }\end{array}$ & & $\mathrm{Kg}$ & 1,0 & 7,20 & 7,20 \\
\hline TOTAL & & & & & 66,31 \\
\hline
\end{tabular}

Fonte: Gurgel Filho et al. (1978), Instituto Florestal e dados de pesquisa

Tabela 38 - Custo Anual de Manutenção do $4^{\circ}$ ao $25^{\circ}$ ano de 1 ha plantado com pau-marfim

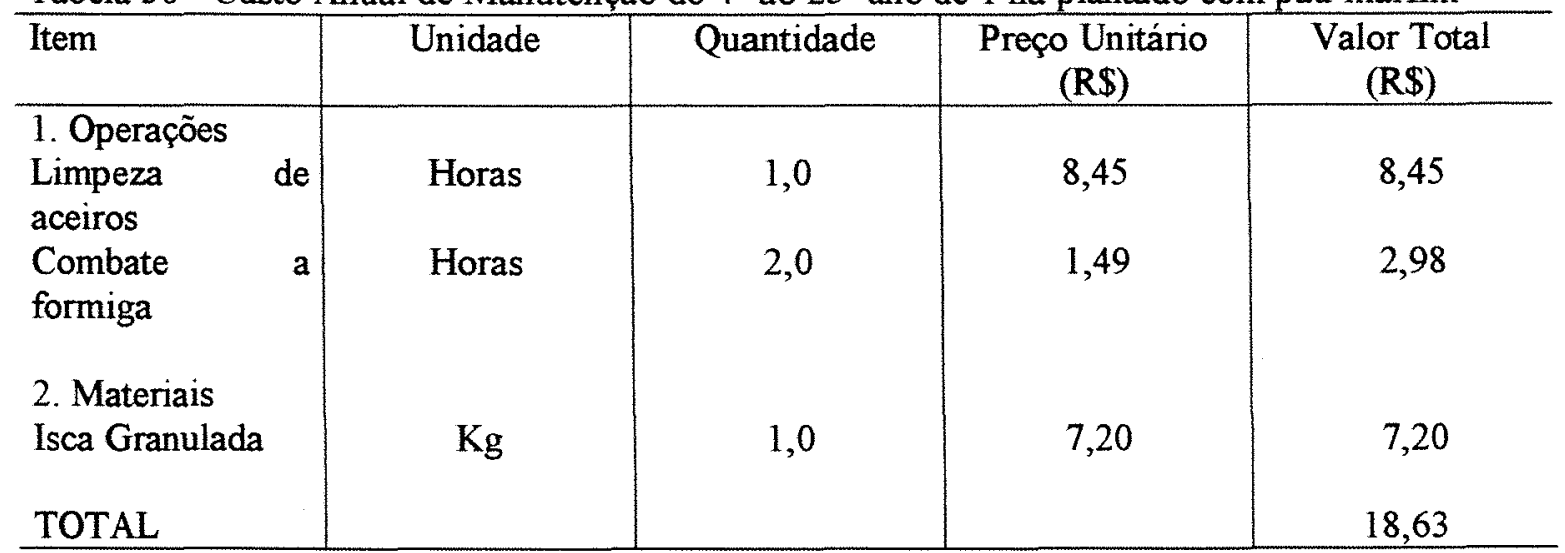

Fonte: Gurgel Filho et al. (1978), Instituto Florestal e dados de pesquisa

2. Projeto M2 - Plantio do pau-marfim em terra arrendada e com aquisição de mudas

\subsection{Benefícios}

Idem do item 1.1.2

\subsection{Custos}

\subsubsection{Investimento Inicial (ano 0) Idem do item 1.2.1.2 \\ 2.2.2 Custo de Manutenção Anual Idem do item 1.2.2}




\subsubsection{Arrendamento Anual da Terra}

R\$ 107,44/ha.ano

3. Projeto M3 - Plantio do pau-marfim sem considerar o custo da terra e com a aquisição de mudas

\subsection{Benefícios}

Idem do item 1.1.2

\subsection{Custos}

\subsubsection{Investimento Inicial (ano 0)} Idem do item 1.2.1.2

\subsubsection{Custo de Manutenção Anual} Idem do item 1.2.2

4. Projeto M4 - Plantio do pau-marfim em terra comprada e com mudas doadas pelo governo

\subsection{Benefícios}

Idem do item 1.1

\subsection{Custos}

\subsubsection{Investimento Inicial (ano 0)}

\subsubsection{Compra da terra}

Idem do item 1.2.1.1

\subsubsection{Custo de Implantação}

Tabela 39 - Custo de implantação de 1 hectare de pau-marfím com mudas doadas pelo governo

\begin{tabular}{l|c|c|c|c}
\hline Item & Unidade & Quantidade & $\begin{array}{c}\text { Preço Unitário } \\
\text { (R\$) }\end{array}$ & $\begin{array}{c}\text { Valor Total } \\
\text { (R\$) }\end{array}$ \\
\hline 1. Operações & & & & 21,13 \\
Aração & Horas & 2,5 & 8,45 & 21,13 \\
Gradeação & Horas & 2,5 & 8,45 & 77,48 \\
Balizamento & Horas & 52,0 & 1,49 & 89,40 \\
Coveamento & Horas & 60,0 & 1,49 & 89,40 \\
Plantio & Horas & 60,0 & 1,49 & 298,54 \\
\hline
\end{tabular}

Fonte: Gurgel Filho et al. (1978); Instituto Florestal; e, dados de pesquisa

\subsubsection{Custo Anual de Manutenção} Idem do item 1.2.2 
5. Projeto M5 - Plantio do pau-marfim em terra arrendada e com mudas doadas pelo governo

\subsection{Benefícios}

Idem do item 1.1.2

\subsection{Custos}

\subsubsection{Investimento Inicial (ano 0)} Idem do item 4.2.1.2

\subsubsection{Custos de Manutenção} Idem do item 1.2.2

\subsubsection{Arrendamento da Terra} Idem do item 2.2.3

6. Projeto M6 - Plantio do pau-marfim sem considerar o custo da terra e com mudas doadas pelo governo

\subsection{Benefícios}

Idem do item 1.1.2

\subsection{Custos}

\subsubsection{Investimento Inicial (ano 0)} Idem do item 4.2.1.2

\subsubsection{Custos de Manutenção} Idem do item 1.2.2 
Apêndice 6 - Informações gerais sobre os beneficios e custos do reflorestamento com o pinheiro-brasileiro (Araucaria angustifolia). 
- Quantidades e preços dos produtos e subprodutos da exploração florestal

Os dados de produção do pinheiro-brasileiro utilizados para os projetos P1, P2, P3, P4, P5 e P6 estão baseados nos resultados obtidos do Projeto 2/52-SR, instalado na Estação Experimental de Santa Rita do Passa Quatro, do Instituto Florestal, sob espaçamento 2,0 x 2,0 metros, em 1952. Segundo Gurgel Filho et al.(1978), o incremento volumétrico anual de madeira é de 11,67 metros cúbicos por hectare $\left(\mathrm{m}^{3} / \mathrm{ha}\right)$. No $21^{0}$ ano foi realizado o $4^{0}$ desbaste do qual se obteve $31,749 \mathrm{~m}^{3}$ de madeira por hectare. De acordo com os históricos dos experimentos, os desbastes anteriores ocorreram no $6^{\circ}, 10^{\circ}$ e $12^{\circ}$ anos. Já o volume desbastado desses anos é obtido da seguinte forma:

$\mathrm{V}_{\mathrm{i}}=\left(\mathrm{VT}_{21}-\mathrm{VP}_{21}\right) / 3=(11,67 \times 21-232,052) / 3=4,3393$

Onde:

$V_{i}=$ volume desbastado no ano $i$, em $\mathrm{m}^{3} / \mathrm{ha}$, onde $\mathrm{i}=6,10$ ou 12

$\mathrm{VT}_{21}=$ volume total aos 21 anos, sem desbaste, $\mathrm{em} \mathrm{m}^{3} / \mathrm{ha}$

$\mathrm{VP}_{21}=$ volume presente aos 21 anos antes do $4^{\circ}$ desbaste, $\mathrm{em} \mathrm{m}^{3} / \mathrm{ha}$

O volume previsto para o $25^{\circ}$ ano é calculado assim:

$\mathrm{V}_{25}=\mathrm{VR}_{21}+4 \mathrm{x}$ IVA $=200,303+4 \times 11,67=246,98$

Onde:

$\mathrm{V}_{25}=$ volume existente aos 25 anos, em $\mathrm{m}^{3} / \mathrm{ha}$

$\mathrm{VR}_{21}=$ volume remanescente aos 21 anos, após o $4^{0}$ desbaste, $\mathrm{em} \mathrm{m}^{3} / \mathrm{ha}$

IVA $=$ incremento volumétrico anual, $\mathrm{em}^{3} / \mathrm{ha}$.

Os preços dos subprodutos (lenha, repique e moirão) foram levantados junto às serrarias da região, em março de 1999. A lenha foi cotada a $\mathrm{R} \$ 3,00 / \mathrm{m}^{3}$ e a madeira para repique e moirão foi cotada a $\mathrm{R} \$ 20,00 / \mathrm{m}^{3}$. O preço do produto principal do reflorestamento - a tora para o desdobro mecânico - foi obtido da seguinte forma:

a) Distância do município de Curitiba-PR a Santa Rita do Passa Quatro-SP: A = 699 km (fonte: Guia Quatro Rodas. Brasil, 1999.)

b) Frete rodoviário para transporte da madeira em toretes: $B=R \$ 0,0437 / \mathrm{km}$ (fonte: INFORME SIFRECA - ano 3 - $\mathrm{n}^{\circ} 23$ - março 1999). Frete relativo ao percurso de $410 \mathrm{~km}$ entre Itararé (SP) e Suzano (SP).

c) Densidade da madeira do pinheiro-brasileiro: $C=0,55 \mathrm{~g} / \mathrm{cm}^{3}$ (Lorenzi, 1992). 
d) Cálculo do frete de $1 \mathrm{~m}^{3}$ de toras de pinheiro de Curitiba-PR a Santa Rita do Passa Quatro: $\mathrm{D}=\mathrm{A} \times \mathrm{B} \times \mathrm{C}=699 \mathrm{~km} \times \mathrm{R} \$ 0,0437 / \mathrm{t} . \mathrm{km} \times 0,55 \mathrm{t} / \mathrm{m}^{3}=\mathrm{R} \$ 16,80 / \mathrm{m}^{3}$

e) Preço da madeira em pé na região de Curitiba, em março de 1999 (fonte: Sindicato dos Madeireiros do Estado do Paraná)

Preço Médio: $\mathrm{E}=\mathrm{R} \$ 80,00 / \mathrm{m}^{3}$

f) Cálculo do preço da madeira em pé na região de Santa Rita do Passa Quatro $\mathrm{F}=\mathrm{D}+\mathrm{E}=\mathrm{R} \$ 16,80 / \mathrm{m}^{3}+\mathrm{R} \$ 80,00 / \mathrm{m}^{3}=\mathrm{R} \$ 96,80 / \mathrm{m}^{3}$

1. Projeto P1 - Plantio do pinheiro-brasileiro em terra comprada e com a aquisição de mudas.

\section{1 - Benefícios}

1.1.1 - Receita da venda da terra no final do projeto

O preço praticado na região para o tipo de solo utilizado no experimento foi cotado a R\$1652,89 por hectare, segundo levantamento feito por técnicos da Estação Experimental de Santa Rita do Passa Quatro, do Instituto Florestal, em março de 1999.

1.1.2 - Receitas das vendas dos subprodutos e produtos da exploração florestal

Tabela 40 - Receitas das vendas dos produtos e subprodutos da exploração florestal de 1 ha plantado com pinheiro-brasileiro

\begin{tabular}{c|c|c|c}
\hline $\begin{array}{c}\text { Idade } \\
\text { (anos) }\end{array}$ & $\begin{array}{c}\text { Volume Retirado } \\
\left(\mathrm{m}^{3} / \text { há) }\right.\end{array}$ & $\begin{array}{c}\text { Preço Unitário } \\
\left(\mathrm{R} \$ / \mathrm{m}^{3}\right)\end{array}$ & $\begin{array}{c}\text { Receita Total } \\
(\mathrm{R} \$)\end{array}$ \\
\hline 6 & 4,34 & 3,00 & 13,02 \\
10 & 4,34 & 3,00 & 13,02 \\
12 & 4,34 & 3,00 & 13,02 \\
21 & 31,75 & 20,00 & 635,00 \\
25 & 246,98 & 96,80 & 23907,66 \\
\hline
\end{tabular}

Fonte: Gurgel Filho et al.(1978); dados de pesquisa; e, valores calculados pelo autor

\section{2 - Custos}

1.2.1 - Investimento Inicial (ano 0)

1.2.1.1 - Compra da terra: idem do item 1.1.1.

\subsubsection{2 - Custo de Implantação}


Tabela 41 - Custo de Implantação de 1 hectare de pinheiro-brasileiro com aquisição de mudas

\begin{tabular}{l|c|c|c|c}
\hline \multicolumn{1}{c|}{ Item } & Unidade & Quantidade & $\begin{array}{c}\text { Preço Unitário } \\
\text { (R\$) }\end{array}$ & $\begin{array}{c}\text { Valor Total } \\
\text { (R\$) }\end{array}$ \\
\hline 1. Operações & Horas & 2,5 & 8,45 & 21,13 \\
Aração & Horas & 2,5 & 8,45 & 21,13 \\
Gradeação & Horas & 52,0 & 1,49 & 77,48 \\
Balizamento & Horas & 60,0 & 1,49 & 89,40 \\
Coveamento & Horas & 60,0 & 1,49 & 89,40 \\
Plantio & & & & \\
2. Materiais & Mil & 2,5 & 162,31 & 405,78 \\
Mudas & & & & 704,32 \\
TOTAL & & & & \\
\hline
\end{tabular}

Fonte: Gurgel Filho et al.(1978); Instituto Florestal; e, dados de pesquisa

\subsection{2 - Custos Anuais de Manutenção}

Tabela 42 - Custo de Manutenção no $1^{0}$ ano de 1 ha plantado com pinheiro-brasileiro

\begin{tabular}{|c|c|c|c|c|}
\hline Item & Unidade & Quantidade & $\begin{array}{c}\text { Preço Unitário } \\
\text { (R\$) }\end{array}$ & \begin{tabular}{|c} 
Valor Total \\
(R\$)
\end{tabular} \\
\hline 1. Operações & & & & \\
\hline Trilhação & Horas & 24,0 & 1,49 & 35,76 \\
\hline $\begin{array}{l}\text { Limpeza de } \\
\text { aceiros }\end{array}$ & Horas & 1,0 & 8,45 & 8,45 \\
\hline $\begin{array}{l}\text { Combate } \\
\text { formiga }\end{array}$ & Horas & 19,0 & 1,49 & 28,31 \\
\hline 2. Materiais & & & & \\
\hline Formicida em pó & $\mathrm{Kg}$ & 3,5 & 4,80 & 16,80 \\
\hline Isca Granulada & $\mathrm{Kg}$ & 10,0 & 7,20 & 72,00 \\
\hline TOTAL & & & & 161,32 \\
\hline
\end{tabular}

Fonte: Gurgel Filho et al.(1978); Instituto Florestal; e, dados de pesquisa 
Tabela 43 - Custo Anual de Manutenção do $2^{\underline{0}}$ ao $3^{\underline{0}}$ ano de 1 ha plantado com pinheirobrasileiro

\begin{tabular}{|c|c|c|c|c|}
\hline Item & Unidade & Quantidade & $\begin{array}{c}\text { Preço Unitário } \\
\text { (R\$) }\end{array}$ & $\begin{array}{c}\text { Valor Total } \\
\text { (R\$) }\end{array}$ \\
\hline 1. Operações & & & & \\
\hline Trilhação & Horas & 32,0 & 1,49 & 47,68 \\
\hline $\begin{array}{l}\text { Limpeza de } \\
\text { aceiros }\end{array}$ & Horas & 1,0 & 8,45 & 8,45 \\
\hline $\begin{array}{l}\text { Combate } \\
\text { formiga }\end{array}$ & Horas & 2,0 & 1,49 & 2,98 \\
\hline $\begin{array}{l}\text { 2. Materiais } \\
\text { Isca Granulada }\end{array}$ & $\mathrm{Kg}$ & 1,0 & 7,20 & 7,20 \\
\hline TOTAL & & & & 66,31 \\
\hline
\end{tabular}

Fonte: Gurgel Filho (1978); Instituto Florestal; e, dados de pesquisa

Tabela 44 - Custo Anual de Manutenção do $4^{0}$ ao $25^{0}$ ano de 1 ha plantado com pinheirobrasileiro

\begin{tabular}{|c|c|c|c|c|}
\hline Item & Unidade & Quantidade & $\begin{array}{c}\text { Preço Unitário } \\
\text { (RS) }\end{array}$ & $\begin{array}{c}\text { Valor Total } \\
\text { (R\$) }\end{array}$ \\
\hline 1. Operações & & & & \\
\hline $\begin{array}{l}\text { Limpeza } \\
\text { aceiros }\end{array}$ & Horas & 1,0 & 8,45 & 8,45 \\
\hline $\begin{array}{l}\text { Combate } \\
\text { formiga }\end{array}$ & Horas & 2,0 & 1,49 & 2,98 \\
\hline $\begin{array}{l}\text { 2. Materiais } \\
\text { Isca Granulada }\end{array}$ & $\mathrm{Kg}$ & 1,0 & 7,20 & 7,20 \\
\hline TOTAL & & & & \\
\hline
\end{tabular}

Fonte: Gurgel Filho (1978); Instituto Florestal; e, dados de pesquisa

2. Projeto P2 - Plantio do pinheiro-brasileiro em terra arrendada e com mudas adquiridas.

\subsection{Benefícios}

Idem do item 1.1.2

\subsection{Custos}

2.2.1 Investimento Inicial (ano 0)

Idem do item 1.2.1.2

\subsubsection{Custo de Manutenção Anual} Idem do item 1.2.2 


\subsubsection{Arrendamento Anual da Terra}

RS 107,44/ha.ano

3. Projeto P3 - Plantio do pinheiro-brasileiro sem considerar o custo da terra e com a aquisição de mudas

\subsection{Benefícios}

Idem do item 1.1.2

\subsection{Custos}

3.2.1 Investimento Inicial (ano 0)

Idem do item 1.2.1.2

\subsubsection{Custo de Manutenção Anual} Idem do item 1.2.2

4. Projeto P4 - Plantio do pinheiro-brasileiro em terra comprada e com mudas doadas pelo governo.

\subsection{Beneficios}

Idem do item 1.1

\subsection{Custos}

\subsubsection{Investimento Inicial (ano 0)}

\subsubsection{Compra da terra}

Idem do item 1.2.1.1

\subsubsection{Custo de Implantação}

Tabela 45 - Custo de Implantação de 1 hectare de pinheiro-brasileiro com mudas doadas pelo governo

\begin{tabular}{l|l|l|c|c}
\hline Item & Unidade & Quantidade & $\begin{array}{c}\text { Preço Unitário } \\
\text { (R\$) }\end{array}$ & $\begin{array}{c}\text { Valor Total } \\
\text { (R\$) }\end{array}$ \\
\hline 1. Operações & & & 8,45 & \\
Aração & Horas & 2,5 & 8,45 & 21,13 \\
Gradeação & Horas & 2,5 & 1,49 & 21,13 \\
Balizamento & Horas & 52,0 & 1,49 & 77,48 \\
Coveamento & Horas & 60,0 & 1,49 & 89,40 \\
Plantio & Horas & 60,0 & & 89,40 \\
TOTAL & & & & 298,54 \\
\hline
\end{tabular}

Fonte: Gurgel Filho et al.(1978); Instituto Florestal; e, dados de pesquisa

\subsubsection{Custo Anual de Manutenção}

Idem do item 1.2.2 
5. Projeto P5 - Plantio do pinheiro-brasileiro em terra arrendada e com mudas doadas pelo governo.

\subsection{Benefícios}

Idem do item 1.1.2

\subsection{Custos}

5.2.1 Investimento Inicial (ano 0)

Idem do item 4.2.1.2

5.2.2 Custos de Manutenção

Idem do item 1.2.2

\subsubsection{Arrendamento da Terra}

Idem do item 2.2.3

6. Projeto P6 - Plantio do pinheiro-brasileiro sem considerar o custo da terra e com mudas doadas pelo governo

\subsection{Benefícios}

Idem do item 1.1.2

\subsection{Custos}

\subsubsection{Investimento Inicial (ano 0) Idem do item 4.2.1.2}

\subsubsection{Custos de Manutenção} Idem do item 1.2.2 
Apêndice 7 - Informações gerais sobre os beneficios e custos do reflorestamento com a araruva (Centrolobium tomentosum). 


\section{- Quantidades e preços dos produtos e subprodutos da exploração florestal}

Os dados de produção da araruva utilizados para os projetos A1, A2, A3, A4, A5 e A6 são baseados nos resultados obtidos do Projeto 27/56-SR, instalado na Estação Experimental de Santa Rita do Passa Quatro, do Instituto Florestal, sob espaçamento 2,5 x 2,5 metros, em 1956. Segundo Gurgel Filho et al.(1978), nas condições do experimento, o incremento volumétrico anual de madeira é de 14,443 metros cúbicos por hectare $\left(\mathrm{m}^{3} / \mathrm{ha}\right)$. No $16^{0}$ ano foi realizado o $6^{0}$ desbaste do qual obteve-se $37,653 \mathrm{~m}^{3}$ de madeira por hectare. De acordo com os históricos dos experimentos, os desbastes anteriores ocorreram no $10^{0}, 11^{0}, 12^{0}, 13^{0}, 14^{0}$ e 16 anos e, as produções de madeira foram de $4,00,10,00,5,00,6,00$ e $18,19 \mathrm{~m}^{3} / \mathrm{ha}$, respectivamente.

$O$ volume previsto para o $25^{\circ}$ ano é calculado da seguinte forma:

$\mathrm{V}_{25}=\mathrm{VR}_{16}+9 \mathrm{xIVA}=150,248+9 \times 14,443=280,235$

Onde:

$\mathrm{V}_{25}=$ volume esperado para $\circ 25^{0}$ ano, em $\mathrm{m}^{3} / \mathrm{ha}$

$\mathrm{VR}_{16}=$ volume remanescente após o $6^{0}$ desbaste, no $16^{\circ}$ ano, $\mathrm{em} \mathrm{m}^{3} / \mathrm{ha}$

IVA $=$ incremento volumétrico anual, $\mathrm{em}^{3} / \mathrm{ha}$

Os preços dos subprodutos (lenha, repique e moirão) foram levantados junto as serrarias da região, em março de 1999. A lenha foi cotada a $\mathrm{R} \$ 3,00 / \mathrm{m}^{3}$ e a madeira para repique e moirão foi cotada a $\mathrm{R} \$ 20,00 / \mathrm{m}^{3}$. O preço do produto principal do reflorestamento - a tora para o desdobro mecânico - é obtido da seguinte forma:

a) Cálculo da distância do município de Sinop-MT a Santa Rita do Passa Quatro: A=1861 km (fonte: Guia Quatro Rodas. Brasil, 1999.)

b) levantamento do frete rodoviário para transporte da madeira em toretes: $B=R \$ 0,0437 / \mathrm{t} . \mathrm{km}$ (fonte: INFORME SIFRECA - ano 3 - no 23 - março 1999). Frete relativo ao percurso de $410 \mathrm{~km}$ entre Itararé (SP) e Suzano (SP).

c) Levantamento da densidade da madeira da araruva: $C=0,75 \mathrm{~g} / \mathrm{cm}^{3}$ (Lorenzi, 1992).

d) Cálculo do frete de $1 \mathrm{~m}^{3}$ de toras de araruva de Sinop-MT a Santa Rita do Passa Quatro: D = $\mathrm{A} \times \mathrm{B} \times \mathrm{C}=1861 \mathrm{~km} \times \mathrm{R} \$ 0,0437 / \mathrm{t} . \mathrm{km} \times 0,75 \mathrm{t} / \mathrm{m}^{3}=\mathrm{R} \$ 60,99 / \mathrm{m}^{3}$

e) Levantamento do preço da madeira em tora na serraria na região Norte, em janeiro' de 1999 (fonte: http://www.itto.jp.or)

\footnotetext{
${ }^{1}$ Optou-se por trabalhar com o preço em reais de janeiro de 1999 pelo fato de haver indícios do mesmo ter se mantido até abril do corrente ano.
} 
Espécie: jatobá $=$ U\$ $45,00 / \mathrm{m}^{3}$ e ipê $=U \$ 68,00 / \mathrm{m}^{3}$

Preço Médio: $E=U \$ 56,50 / \mathrm{m}^{3}$ ou $\mathrm{R} \$ 68,38 / \mathrm{m}^{3}$ ( U\$ $1,00=\mathrm{R} \$ 1,2103$ )

f) Cálculo do preço da madeira em tora na serraria em Santa Rita Passa Quatro $\mathrm{F}=\mathrm{D}+\mathrm{E}=\mathrm{R} \$ 60,99 / \mathrm{m}^{3}+\mathrm{R} \$ 68,38 / \mathrm{m}^{3}=\mathrm{R} \$ 129,37 / \mathrm{m}^{3}$

g) Levantamento do custo de exploração da madeira

Segundo empresas da região o custo do corte e transporte da madeira do campo até a serraria, para uma distância máxima de $50 \mathrm{Km}$, é de $\mathrm{G}=\mathrm{R} \$ 15,00 / \mathrm{m}^{3}$

h) Cálculo do preço da madeira em pé na região de Santa Rita Passa Quatro $\mathrm{H}=\mathrm{F}-\mathrm{G}=\mathrm{R} \$ 129,37-\mathrm{R} \$ 15,00=\mathrm{R} \$ 114,37$

1. Projeto A1 - Plantio da araruva em terra comprada e com aquisição das mudas

\section{1 - Benefícios}

1.1.1 - Receita da venda da terra no final do projeto

O preço praticado na região para o tipo de solo utilizado no experimento foi cotado a $R \$$ 1652,89 por hectare, segundo levantamento feito por técnicos da Estação Experimental de Santa Rita do Passa Quatro, do Instituto Florestal, em março de 1999.

1.1.2 - Receitas das vendas dos subprodutos e produtos da exploração florestal

Tabela 46 - Receitas da venda de subprodutos e produtos da exploração florestal de 1 ha plantado com araruva

\begin{tabular}{c|c|c|c}
\hline $\begin{array}{c}\text { Idade } \\
\text { (anos) }\end{array}$ & $\begin{array}{c}\text { Volume Retirado } \\
\left(\mathrm{m}^{3} / \mathrm{ha}\right)\end{array}$ & $\begin{array}{c}\text { Preço Unitário } \\
\left(\mathrm{R} \$ / \mathrm{m}^{3}\right)\end{array}$ & $\begin{array}{c}\text { Receita Total } \\
(\mathrm{R} \$)\end{array}$ \\
\hline 10 & 4,00 & 3,00 & 12,00 \\
11 & 10,00 & 3,00 & 30,00 \\
12 & 5,00 & 3,00 & 15,00 \\
13 & 6,00 & 3,00 & 18,00 \\
14 & 18,19 & 3,00 & 54,57 \\
16 & 37,65 & 20,00 & 753,00 \\
25 & 280,24 & 114,37 & 32051,05 \\
\hline
\end{tabular}

Fonte: Gurgel Filho et al.(1978); dados de pesquisa; e, valores calculados pelo autor

\section{2 - Custos}

1.2.1 - Investimento Inicial (ano 0)

\subsubsection{1 - Compra da terra}

idem do item 1.1.1. 
1.2.1.2 - Custo de Implantação

Tabela 47 - Custo de Implantação de 1 hectare da araruva com aquisição de mudas

\begin{tabular}{l|r|r|r|r}
\hline \multicolumn{1}{c|}{ Item } & Unidade & Quantidade & $\begin{array}{r}\text { Preço Unitário } \\
\text { (R\$) }\end{array}$ & \multicolumn{2}{|c}{$\begin{array}{c}\text { Valor Total } \\
\text { (R\$) }\end{array}$} \\
\hline 1. Operações & Horas & 2,5 & 8,45 & 21,13 \\
Aração & Horas & 2,5 & 8,45 & 21,13 \\
Gradeação & Horas & 35,0 & 1,49 & 52,15 \\
Balizamento & Horas & 40,0 & 1,49 & 59,60 \\
Coveamento & Horas & 40,0 & 1,49 & 59,60 \\
Plantio & & & & \\
2. Materiais & Mil & 1,6 & 623,37 & 997,39 \\
Mudas & & & & 1211,00 \\
\hline
\end{tabular}

Fonte: Gurgel Filho et al.(1978); dados de pesquisa; e, Instituto Florestal

\subsection{2 - Custos Anuais de Manutenção}

Tabela 48 - Custo de Manutenção do $1^{0}$ ano de 1 ha plantado com araruva

\begin{tabular}{l|l|l|l|l}
\hline Item & Unidade & Quantidade & $\begin{array}{c}\text { Preço Unitário } \\
\text { (R\$) }\end{array}$ & $\begin{array}{c}\text { Valor Total } \\
\text { (R\$) }\end{array}$ \\
\hline 1. Operações & & 24,0 & 1,49 & 35,76 \\
Trilhação & Horas & 1,0 & 8,45 & 8,45 \\
Limpeza de aceiros & Horas & 19,0 & 1,49 & 28,31 \\
Combate a formiga & Horas & & & \\
& & 3,5 & 4,80 & 16,80 \\
2. Materiais & $\mathrm{Kg}$ & 10,0 & 7,20 & 72,00 \\
Formicida em pó & $\mathrm{Kg}$ & & & 161,32 \\
Isca Granulada & & & & \\
TOTAL & & & & \\
\hline
\end{tabular}

Fonte: Gurgel Filho et al.(1978); dados de pesquisa; e, Instituto Florestal 
Tabela 49 - Custo Anual de Manutenção do $2^{0}$ e $3^{0}$ anos de 1 ha plantado com araruva

\begin{tabular}{|c|c|c|c|c|c|}
\hline Item & & Unidade & Quantidade & \begin{tabular}{|c} 
Preço Unitário \\
(RS)
\end{tabular} & $\begin{array}{c}\text { Valor Total } \\
\text { (R\$) }\end{array}$ \\
\hline 1. Operações & & & & & \\
\hline Trilhação & & Horas & 32,0 & 1,49 & 47,68 \\
\hline $\begin{array}{l}\text { Limpeza } \\
\text { aceiros }\end{array}$ & de & Horas & 1,0 & 8,45 & 8,45 \\
\hline $\begin{array}{l}\text { Combate } \\
\text { formiga }\end{array}$ & a & Horas & 2,0 & 1,49 & 2,98 \\
\hline $\begin{array}{l}\text { 2. Materiais } \\
\text { Isca Granulada }\end{array}$ & & $\mathrm{Kg}$ & 1,0 & 7,20 & 7,20 \\
\hline TOTAL & & & & & 66,31 \\
\hline
\end{tabular}

Fonte: Gurgel Filho et al.(1978); dados de pesquisa; e, Instituto Florestal

Tabela 50 - Custo Anual de Manutenção do $4^{0}$ ao $25^{\circ}$ ano de 1 ha plantado com araruva

\begin{tabular}{|c|c|c|c|c|}
\hline Item & Unidade & Quantidade & $\begin{array}{c}\text { Preço Unitário } \\
\text { (RS) }\end{array}$ & $\begin{array}{l}\text { Valor Total } \\
\text { (R\$) }\end{array}$ \\
\hline 1. Operações & & & & \\
\hline $\begin{array}{l}\text { Limpeza } \\
\text { aceiros }\end{array}$ & Horas & 1,0 & 8,45 & 8,45 \\
\hline $\begin{array}{l}\text { Combate } \\
\text { formiga }\end{array}$ & Horas & 2,0 & 1,49 & 2,98 \\
\hline $\begin{array}{l}\text { 2. Materiais } \\
\text { Isca Granulada }\end{array}$ & $\mathrm{Kg}$ & 1,0 & 7,20 & 7,20 \\
\hline TOTAL & & & & 18,63 \\
\hline
\end{tabular}

Fonte: Gurgel Filho et al.(1978); dados de pesquisa; e, Instituto Florestal

2. Projeto A2 - Plantio da araruva em terra arrendada e com aquisição das mudas

\subsection{Benefícios}

Idem do item 1.1.2

\subsection{Custos}

2.2.1 Investimento Inicial (ano 0)

Idem do item 1.2.1.2

2.2.2 Custo de Manutenção Anual

Idem do item 1.2.2

\subsubsection{Arrendamento da Terra}

R\$ 107,44/ha.ano 
3. Projeto A3 - Plantio da araruva sem considerar o custo da terra e com a aquisição de mudas

\subsection{Benefícios}

Idem do item 1.1.2

\subsection{Custos}

3.2.1 Investimento Inicial (ano 0)

Idem do item 1.2.1.2

\subsubsection{Custo de Manutenção Anual} Idem do item 1.2.2

4. Projeto A4 - Plantio da araruva em terra comprada e com doação de mudas pelo govemo

\subsection{Benefícios}

Idem do item 1.1

\subsection{Custos}

4.2.1 Investimento Inicial (ano 0)

\subsubsection{Compra da terra}

Idem do item 1.2.1.1

\subsubsection{Custo de Implantação}

Tabela 51 - Custo de Implantação de 1 hectare de aranuva com mudas doadas pelo governo

\begin{tabular}{l|l|l|c|c}
\hline Item & Unidade & Quantidade & $\begin{array}{c}\text { Preço Unitário } \\
\text { (R\$) }\end{array}$ & $\begin{array}{c}\text { Valor Total } \\
\text { (R\$) }\end{array}$ \\
\hline 1. Operações & & & & \\
Aração & Horas & 2,5 & 8,45 & 21,13 \\
Gradeação & Horas & 2,5 & 8,45 & 21,13 \\
Balizamento & Horas & 35,0 & 1,49 & 52,15 \\
Coveamento & Horas & 40,0 & 1,49 & 59,60 \\
Plantio & Horas & 40,0 & 1,49 & 59,60 \\
TOTAL & & & & 213,61 \\
\hline
\end{tabular}

Fonte: Gurgel Filho et al.(1978); dados de pesquisa; e, Instituto Florestal

\subsubsection{Custo Anual de Manutenção}

Idem do item 1.2 .2

5. Projeto A5 - Plantio da araruva em terra arrendada e com doação de mudas pelo governo

\subsection{Benefícios idem do item 1.1.2}


5.2 Custos

5.2.1 Investimento Inicial (ano 0)

Idem do item 4.2.1.2

5.2.2 Custos de Manutenção

Idem do item 1.2.2

5.2.3 Arrendamento da Terra

Idem do item 2.2 .3

6. Projeto A6 - Plantio de araruva sem considerar o custo da terra e com a doação de mudas pelo governo

\subsection{Benefícios}

idem do item 1.1.2

\subsection{Custos}

6.2.1 Investimento Inicial (ano 0)

Idem do item 4.2.1.2

6.2.2 Custos de Manutenção

Idem do item 1.2.2 
Apêndice 8 - Informações gerais para a elaboração de novos cenários (otimistas ou pessimistas) para os projetos de reflorestamento com nativas 


\section{PAU-MARFIM}

\subsection{CENÁRIOS OTIMISTAS}

1.1.1 Segundo Gurgel Filho et al. (1982f), o melhoramento florestal poderia proporcionar aumentos superiores a $20 \%$ no crescimento volumétrico anual, desde que haja uma população mais uniforme. Estimando-se que o aumento seja de $25 \%$, o crescimento volumétrico anual passaria de $11,601 \mathrm{~m}^{3} / \mathrm{ha}$ para $14,50 \mathrm{~m}^{3} / \mathrm{ha}$. Assim, as receitas das vendas de subprodutos e produtos da exploração florestal de 1 ha com pau-marfim passariam a ser aquelas contidas na tabela 52 .

Tabela 52 - Receitas das vendas de subprodutos e produtos da exploração florestal de 1 ha de pau-marfim incorporando o efeito do melhoramento florestal

\begin{tabular}{c|c|c|c}
\hline $\begin{array}{c}\text { Idade } \\
\text { (anos) }\end{array}$ & $\begin{array}{c}\text { Volume Retirado } \\
\left(\mathrm{m}^{3} / \mathrm{ha}\right)\end{array}$ & $\begin{array}{c}\text { Preço Unitário } \\
\left(\mathrm{R} \$ / \mathrm{m}^{3}\right)\end{array}$ & $\begin{array}{c}\text { Receita Total } \\
(\mathrm{R} \$)\end{array}$ \\
\hline 12 & 26,34 & 3,00 & 79,02 \\
13 & 26,34 & 3,00 & 79,02 \\
14 & 26,34 & 3,00 & 79,02 \\
15 & 26,34 & 3,00 & 79,02 \\
20 & 41,74 & 20,00 & 834,80 \\
25 & 215,43 & 121,69 & 26215,68 \\
\hline
\end{tabular}

Fonte: Gurgel Filho et al. (1982f); Gurgel Filho et al. (1978); dados de pesquisa;e, valores calculados pelo autor.

1.1.2 Conforme foi visto no capitulo 3, existem grupos de consumidores dispostos a pagar preços 5 a $15 \%$ maiores por procutos florestais certificados quanto sua origem. Este pode ser o caso dos reflorestamentos com essências nativas. Pressupondo-se um acréscimo médio de 10\%, o preço da madeira em pé passaria de $\mathrm{R} \$ 121,69 / \mathrm{m}^{3}$ para $\mathrm{R} \$ 133,86 / \mathrm{m}^{3}$. Assim, as receitas das vendas de subprodutos e produtos da exploração florestal de 1 ha com pau-marfim passariam a ser aquelas contidas na tabela 53 .

Tabela 53 - Receitas das vendas de subprodutos e produtos da exploração florestal de 1 ha de pau-marfim incorporando o efeito do manejo sustentado

\begin{tabular}{c|c|c|c}
\hline $\begin{array}{c}\text { Idade } \\
\text { (anos) }\end{array}$ & $\begin{array}{c}\text { Volume Retirado } \\
\left(\mathrm{m}^{3} / \mathrm{ha}\right)\end{array}$ & $\begin{array}{c}\text { Preço Unitário } \\
\left(\mathrm{R} \$ / \mathrm{m}^{3}\right)\end{array}$ & $\begin{array}{c}\text { Receita Total } \\
\text { (R\$) }\end{array}$ \\
\hline 12 & 21,07 & 3,00 & 63,21 \\
13 & 21,07 & 3,00 & 63,21 \\
14 & 21,07 & 3,00 & 63,21 \\
15 & 21,07 & 3,00 & 63,21 \\
20 & 33,39 & 20,00 & 667,80 \\
25 & 172,34 & 133,86 & 23069,43 \\
\hline
\end{tabular}

Fonte: Gurgel Filho et al. (1982f); Gurgel Filho et al. (1978); dados de pesquisa;e, valores calculados pelo autor.

1.1.3 O preço de aquisição da terra utilizado no trabalho corresponde a área que foi utilizada para o experimento. No entanto, a utilização de outras áreas com preços menores, sem prejuízo da produtividade, é uma situação possível. Estima-se que o preço de aquisição da terra poderia ser reduzido em $25 \%$ passando de $R \$ 1652,89 /$ ha para $R \$ 1239,67 /$ ha. 
1.1.4 Outro importante aspecto a ser considerado é o aperfeiçoamento na tecnologia de produção de mudas e o impacto no custo de implantação do projeto. Se pressupormos o preço da muda do pau-marfim no mesmo patamar do preço das exóticas pinus e eucaliptus (R $\$ 90,00 /$ mil mudas), o custo de implantação de 1 ha de pau-marfim passaria de $\mathrm{R} \$ 1018,29 / \mathrm{ha}$ para $\mathrm{R} \$ 523,54 / \mathrm{ha}$.

\subsection{CENÁRIOS PESSIMISTAS}

1.2.1 Um dos aspectos que influencia o preço da madeira é o frete incorporado a este. Neste trabalho, o transporte considerado foi o rodoviário, no entanto, pressupondo-se a utilização de outras modalidades de transporte (ferrovia, hidrovia), estima-se uma redução de $33 \%$ no frete da madeira. Com isso, o preço da madeira em pé (tora) passaria de $\mathrm{R} \$ 121,69 / \mathrm{m}^{3}$ para $\mathrm{R} \$ 99,15 / \mathrm{m}^{3}$. Assim, as receitas das vendas de subprodutos e produtos da exploração florestal de 1 ha com paumarfim passariam a ser aquelas contidas na tabela 54 .

Tabela 54 - Receitas das vendas de subprodutos e produtos da exploração florestal de 1 ha de pau-marfim incorporando o efeito do frete

\begin{tabular}{c|c|c|c}
\hline $\begin{array}{c}\text { Idade } \\
\text { (anos) }\end{array}$ & $\begin{array}{c}\text { Volume Retirado } \\
\left(\mathrm{m}^{3} / \mathrm{ha}\right)\end{array}$ & $\begin{array}{c}\text { Preço Unitário } \\
\left(\mathrm{R} \$ / \mathrm{m}^{3}\right)\end{array}$ & $\begin{array}{c}\text { Receita Total } \\
(\mathrm{R} \$)\end{array}$ \\
\hline 12 & 21,07 & 3,00 & 63,21 \\
13 & 21,07 & 3,00 & 63,21 \\
14 & 21,07 & 3,00 & 63,21 \\
15 & 21,07 & 3,00 & 63,21 \\
20 & 33,39 & 20,00 & 667,80 \\
25 & 172,34 & 99,15 & 17087,51 \\
\hline
\end{tabular}

Fonte: Gurgel Filho et al. (1982f); Gurgel Filho et al. (1978); dados de pesquisa:e, valores calculados pelo autor.

1.2.2 Outro aspecto que influencia o preço da madeira em pé é a heterogeneidade da população em função do material genético existente. Isto porque parte das árvores reflorestadas não estariam em condições para serem utilizadas como toras. Assim, estima-se que o preço da madeira em pé poderia sofrer uma redução de até $40 \%$, ou seja. passaria de $\mathrm{R} \$ 121,69 / \mathrm{m}^{3}$ para $\mathrm{R} \$ 73,01 / \mathrm{m}^{3}$. Com isso, as receitas das vendas de subprodutos e produtos da exploração florestal de 1 ha com paumarfim passariam a ser aquelas contidas na tabela 55 .

Tabela 55 - Receitas das vendas de subprodutos e produtos da exploração florestal de 1 ha de pau-marfim incorporando o efeito da heterogeneidade da população

\begin{tabular}{c|c|c|c}
\hline $\begin{array}{c}\text { Idade } \\
\text { (anos) }\end{array}$ & $\begin{array}{c}\text { Volume Retirado } \\
\left(\mathrm{m}^{3} / \mathrm{ha}\right)\end{array}$ & $\begin{array}{c}\text { Preço Unitário } \\
\left(\mathrm{R} \$ / \mathrm{m}^{3}\right)\end{array}$ & $\begin{array}{c}\text { Receita Total } \\
(\mathrm{R} \$)\end{array}$ \\
\hline 12 & 21,07 & 3,00 & 63,21 \\
13 & 21,07 & 3,00 & 63,21 \\
14 & 21,07 & 3,00 & 63,21 \\
15 & 21,07 & 3,00 & 63,21 \\
20 & 33,39 & 20,00 & 667,80 \\
25 & 172,34 & 73.01 & 12582,54 \\
\hline
\end{tabular}

Fonte: Gurgel Filho et al. (1982f); Gurgel Filho et al. (1978); dados de pesquisa;e, valores calculados pelo autor. 


\section{PINHEIRO-BRASILEIRO}

\subsection{CENÁRIOS OTIMISTAS}

2.1.1 Segundo Gurgel Filho et al. (1982i), o ordenamento florestal e racional adequado, aliado ao material melhorado geneticamente, poderia possibilitar expressivos ganhos dendrométricos em relação aos obtidos na atual pesquisa. Com isso, estima-se que a produtividade poderia ser acrescida em $50 \%$, ou seja, o crescimento volumétrico anual passaria de $11,67 \mathrm{~m}^{3} / \mathrm{ha}$ para 17,51 $\mathrm{m}^{3} / \mathrm{ha}$. Assim, as receitas das vendas de subprodutos e produtos da exploração florestal de 1 ha com pinheiro-brasileiro passariam a ser aquelas contidas na tabela 56.

Tabela 56 - Receitas das vendas de subprodutos e produtos da exploração florestal de 1 ha de pinheirobrasileiro incorporando o efeito do ordenamento e melhoramento florestal

\begin{tabular}{c|c|c|c}
\hline $\begin{array}{c}\text { Idade } \\
\text { (anos) }\end{array}$ & $\begin{array}{c}\text { Volume Retirado } \\
\left(\mathrm{m}^{3} / \mathrm{ha}\right)\end{array}$ & $\begin{array}{c}\text { Preço Unitário } \\
\left(\mathrm{R} \$ / \mathrm{m}^{3}\right)\end{array}$ & $\begin{array}{c}\text { Receita Total } \\
(\mathrm{R} \$)\end{array}$ \\
\hline 6 & 6,51 & 3,00 & 19,53 \\
10 & 6,51 & 3,00 & 19,53 \\
12 & 6,51 & 3,00 & 19,53 \\
21 & 47,63 & 20,00 & 952,60 \\
25 & 370,47 & 96,80 & 35861,50 \\
\hline
\end{tabular}

Fonte: Gurgel Filho et al. (1982i); Gurgel Filho et al. (1978); dados de pesquisa;e, valores calculados pelo autor.

2.1.2 Conforme foi visto no capítulo 3 , existem grupos de consumidores dispostos a pagar preços 5 a $15 \%$ maiores por produtos florestais certificados quanto sua origem. Este pode ser o caso dos reflorestamentos com essências nativas. Pressupondo-se um acréscimo médio de $10 \%$, o preço da madeira em pé sob a forma de tora passaria de $\mathrm{R} \$ 96,80 / \mathrm{m}^{3}$ para $\mathrm{R} \$ 106,48 / \mathrm{m}^{3}$. Assim, as receitas das vendas de subprodutos e produtos da exploração florestal de 1 ha com pinheirobrasileiro passariam a ser aquelas contidas na tabela 58 .

Tabela 57- Receitas das vendas de subprodutos e produtos da exploração florestal de 1 ha de pinheirobrasileiro incorporando o efeito do manejo sustentado

\begin{tabular}{c|c|c|c}
\hline $\begin{array}{c}\text { Idade } \\
\text { (anos) }\end{array}$ & $\begin{array}{c}\text { Volume Retirado } \\
\left(\mathrm{m}^{3} / \mathrm{ha}\right)\end{array}$ & $\begin{array}{c}\text { Preço Unitário } \\
\left(\mathrm{R} \$ / \mathrm{m}^{3}\right)\end{array}$ & $\begin{array}{c}\text { Receita Total } \\
(\mathrm{R} \$)\end{array}$ \\
\hline 6 & 4,34 & 3,00 & 13,02 \\
10 & 4,34 & 3,00 & 13,02 \\
12 & 4,34 & 3,00 & 13,02 \\
21 & 31,75 & 20,00 & 635,00 \\
25 & 246,98 & 106,48 & 26298,43 \\
\hline
\end{tabular}

Fonte: Gurgel Filho et al. (1982i); Gurgel Filho et al. (1978); dados de pesquisa;e, valores calculados pelo autor.

2.1.3 O preço de aquisição da terra utilizado no trabalho corresponde a área que foi utilizada para o experimento. No entanto, a utilização de outras áreas com preços menores, sem prejuízo da produtividade, é uma situação possível. Estima-se que o preço de aquisição da terra poderia ser reduzido em $25 \%$ passando de $\mathrm{R} \$ 1652,89 /$ ha para $\mathrm{R} \$ 1239,67 /$ ha.

2.1.4 Outro importante aspecto a ser considerado é o aperfeiçoamento na tecnologia de produção de mudas e o impacto no custo de implantação do projeto. Se pressupormos o preço da muda do pinheiro no mesmo patamar do preço das exóticas pinus e eucaliptus (R $\$ 90,00$ /mil mudas), o custo de implantação de 1 ha de pinheiro-brasileiro passaria de $\mathrm{R} \$ 704,32 / \mathrm{ha}$ para $\mathrm{R} \$ 523,54 / \mathrm{ha}$. 


\subsection{CENÁRIOS PESSIMISTAS}

2.2.1 Um dos aspectos que influencia o preço da madeira é o frete incorporado a este. Neste trabalho, o transporte considerado foi o rodoviário, no entanto, pressupondo-se a utilização de outras modalidades de transporte (ferrovia, hidrovia), estima-se uma redução de $33 \%$ no frete da madeira. Com isso, o preço da madeira em pé (tora) passaria de $\mathrm{R} \$ 96,80 / \mathrm{m}^{3}$ para $\mathrm{R} \$ 91,26 / \mathrm{m}^{3}$. Assim, as receitas das vendas de subprodutos e produtos da exploração florestal de 1 ha com pinheiro-brasileiro passariam a ser aquelas contidas na tabela 58 .

Tabela 58 - Receitas das vendas de subprodutos e produtos da exploração florestal de 1 ha de pinheirobrasileiro incorporando o efeito do frete

\begin{tabular}{c|c|c|c}
\hline $\begin{array}{c}\text { Idade } \\
(\text { anos })\end{array}$ & $\begin{array}{c}\text { Volume Retirado } \\
\left(\mathrm{m}^{3} / \mathrm{ha}\right)\end{array}$ & $\begin{array}{c}\text { Preço Unitário } \\
\left(\mathrm{R} \$ / \mathrm{m}^{3}\right)\end{array}$ & $\begin{array}{c}\text { Receita Total } \\
(\mathrm{R} \$)\end{array}$ \\
\hline 6 & 4,34 & 3,00 & 13,02 \\
10 & 4,34 & 3,00 & 13,02 \\
12 & 4,34 & 3,00 & 13,02 \\
21 & 31,75 & 20,00 & 635,00 \\
25 & 246,98 & 91,26 & 22539,39 \\
\hline
\end{tabular}

Fonte: Gurgel Filho et al. (1982i); Gurgel Filho et al. (1978); dados de pesquisa;e, valores calculados pelo autor.

2.2.2 Outro aspecto que influencia o preço da madeira em pé é a heterogeneidade da população em função do material genético existente. Isto porque parte das árvores reflorestadas não estaria em condições para serem utilizadas para produzir toras. Assim, estima-se que o preço da madeira em pé poderia sofrer uma redução de até $40 \%$, ou seja, passaria de $\mathrm{R} \$ 96,80 / \mathrm{m}^{3}$ para $\mathrm{R} \$ 58,08 / \mathrm{m}^{3}$. Com isso, as receitas das vendas de subprodutos e produtos da exploração florestal de 1 ha com pinheiro-brasileiro passariam a ser aquelas contidas na tabela 59.

Tabela 59 - Receitas das vendas de subprodutos e produtos da exploração florestal de 1 ha de pinheirobrasileiro incorporando o efeito da heterogeneidade da população

\begin{tabular}{c|c|c|c}
\hline $\begin{array}{c}\text { Idade } \\
\text { (anos) }\end{array}$ & $\begin{array}{c}\text { Volume Retirado } \\
\left(\mathrm{m}^{3} / \mathrm{ha}\right)\end{array}$ & $\begin{array}{c}\text { Preço Unitário } \\
\left(\mathrm{R} \$ / \mathrm{m}^{3}\right)\end{array}$ & $\begin{array}{c}\text { Receita Total } \\
(\mathrm{R} \$)\end{array}$ \\
\hline 6 & 4,34 & 3,00 & 13,02 \\
10 & 4,34 & 3,00 & 13,02 \\
12 & 4,34 & 3,00 & 13,02 \\
21 & 31,75 & 20,00 & 635,00 \\
25 & 246,98 & 58,08 & 14344,60 \\
\hline
\end{tabular}

Fonte: Gurgel Filho et al. (1982i); Gurgel Filho et al. (1978); dados de pesquisa;e, valores calculados pelo autor.

\section{ARARUVA}

\subsection{CENÁRIOS OTIMISTAS}

3.1.1 Segundo Gurgel Filho et al. (1982a), mesmo contando com o material genético existente, porém somando-o aos benefícios dasonômicos e do melhoramento genético pioneiro, é possível estimar um acréscimo de $38,48 \%$ no crescimento volumétrico anual, ou seja, este passaria de 14,443 
$\mathrm{m}^{3} / \mathrm{ha}$ para $20 \mathrm{~m}^{3} / \mathrm{ha}$. Assim, as receitas das vendas de subprodutos e produtos da exploração florestal de 1 ha com araruva passariam a ser aquelas contidas na tabela 60 .

Tabela 60 - Receitas das vendas de subprodutos e produtos da exploração florestal de 1 ha de araruva incorporando o efeito dos benefícios dasonômicos e do melhoramento florestal

\begin{tabular}{c|c|c|c}
\hline $\begin{array}{c}\text { Idade } \\
(\text { anos })\end{array}$ & $\begin{array}{c}\text { Volume Retirado } \\
\left(\mathrm{m}^{3} / \mathrm{ha}\right)\end{array}$ & $\begin{array}{c}\text { Preço Unitário } \\
\left(\mathrm{R} \$ / \mathrm{m}^{3}\right)\end{array}$ & $\begin{array}{c}\text { Receita Total } \\
(\mathrm{R} \$)\end{array}$ \\
\hline 10 & 5,54 & 3,00 & 16,62 \\
11 & 13,85 & 3,00 & 41,55 \\
12 & 6,92 & 3,00 & 20,76 \\
13 & 8,31 & 3,00 & 24,93 \\
14 & 25,19 & 3,00 & 75,57 \\
16 & 52,14 & 20,00 & 1042,80 \\
25 & 388,08 & 114,37 & 44384,71 \\
\hline
\end{tabular}

Fonte: Gurgel Filho et al. (1982a); Gurgel Filho et al. (1978); dados de pesquisa;e, valores calculados pelo autor.

3.1.2 Conforme foi visto no capítulo 3, existem grupos de consumidores dispostos a pagar preços 5 a $15 \%$ maiores por produtos florestais certificados quanto sua origem. Este pode ser o caso dos reflorestamentos com essências nativas. Pressupondo-se um acréscimo médio de 10\%, o preço da madeira em pé passaria de $R \$ 114,37 / \mathrm{m}^{3}$ para $\mathrm{R} \$ 125,81 / \mathrm{m}^{3}$. Assim, as receitas das vendas de subprodutos e produtos da exploração florestal de 1 ha com araruva passariam a ser aquelas contidas na tabela 61 .

Tabela 61 - Receitas das vendas de subprodutos e produtos da exploração florestal de 1 ha de araruva incorporando o efeito do manejo sustentado

\begin{tabular}{c|c|c|c}
\hline $\begin{array}{c}\text { Idade } \\
\text { (anos) }\end{array}$ & $\begin{array}{c}\text { Volume Retirado } \\
\left(\mathrm{m}^{3} / \mathrm{ha}\right)\end{array}$ & $\begin{array}{c}\text { Preço Unitário } \\
\left(\mathrm{R} \$ / \mathrm{m}^{3}\right)\end{array}$ & $\begin{array}{c}\text { Receita Total } \\
(\mathrm{R} \$)\end{array}$ \\
\hline 10 & 4,00 & 3,00 & 12,00 \\
11 & 10,00 & 3,00 & 30,00 \\
12 & 5,00 & 3,00 & 15,00 \\
13 & 6,00 & 3,00 & 18,00 \\
14 & 18,19 & 3,00 & 54,57 \\
16 & 37,65 & 20,00 & 753,00 \\
25 & 280,24 & 125,81 & 35256,99 \\
\hline
\end{tabular}

Fonte: Gurgel Filho et al. (1982a); Gurgel Filho et al. (1978); dados de pesquisa;e, valores calculados pelo autor.

3.1.3 O preço de aquisição da terra utilizado no trabalho corresponde a área que foi utilizada para o experimento. No entanto, a utilização de outras áreas com preços menores, sem prejuízo da produtividade, é uma situação possível. Estima-se que o preço de aquisição da terra poderia ser reduzido em $25 \%$ passando de $\mathrm{R} \$ 1652,89 / \mathrm{ha}$ para $\mathrm{R} \$ 1239,67 / \mathrm{ha}$.

3.1.4 Outro importante aspecto a ser considerado é o aperfeiçoamento na tecnologia de produção de mudas e o impacto no custo de implantação do projeto. Se pressupormos o preço da muda da araruva no mesmo patamar do preço das exóticas pinus e eucaliptus (R $\$ 90,00 /$ mil mudas), o custo de implantação de 1 ha de araruva passaria de $R \$ 1211,00 /$ ha para $R \$ 357,61 /$ ha.

\subsection{CENÁRIOS PESSIMISTAS}


3.2.1 Um dos aspectos que influencia o preço da madeira é o frete incorporado a este. Neste trabalho, o transporte considerado foi o rodoviário, no entanto, pressupondo-se a utilização de outras modalidades de transporte (ferrovia, hidrovia), estima-se uma redução de $33 \%$ no frete da madeira. Com isso, o preço da madeira em pé (tora) passaria de $\mathrm{R} \$ 114,37 / \mathrm{m}^{3}$ para $\mathrm{R} \$ 94,24 / \mathrm{m}^{3}$. Assim, as receitas das vendas de subprodutos e produtos da exploração florestal de 1 ha com pinheiro-brasileiro passariam a ser aquelas contidas na tabela 62 .

Tabela 62 - Receitas das vendas de subprodutos e produtos da exploração florestal de 1 ha de araruva incorporando o efeito do frete

\begin{tabular}{c|c|c|c}
\hline $\begin{array}{c}\text { Idade } \\
\text { (anos) }\end{array}$ & $\begin{array}{c}\text { Volume Retirado } \\
\left(\mathrm{m}^{3} / \mathrm{ha}\right)\end{array}$ & $\begin{array}{c}\text { Preço Unitário } \\
\left(\mathrm{R} \$ / \mathrm{m}^{3}\right)\end{array}$ & $\begin{array}{c}\text { Receita Total } \\
(\mathrm{R} \$)\end{array}$ \\
\hline 10 & 4,00 & 3,00 & 12,00 \\
11 & 10,00 & 3,00 & 30,00 \\
12 & 5,00 & 3,00 & 15,00 \\
13 & 6,00 & 3,00 & 18,00 \\
14 & 18,19 & 3,00 & 54,57 \\
16 & 37,65 & 20,00 & 753,00 \\
25 & 280,24 & 94,24 & 26409,82 \\
\hline
\end{tabular}

Fonte: Gurgel Filho et al. (1982a); Gurgel Filho et al. (1978); dados de pesquisa;e, valores calculados pelo autor.

3.2.2 Outro aspecto que influencia o preço da madeira em pé é a heterogeneidade da população em função do material genético existente. Isto porque parte das árvores reflorestadas não estaria em condições para ser utilizada como toras. Assim, estima-se que o preço da madeira em pé poderia sofrer uma redução de até $40 \%$, ou seja, passaria de $\mathrm{R} \$ 114,37 / \mathrm{m}^{3}$ para $\mathrm{R} \$ 68,62 / \mathrm{m}^{3}$. Com isso, as receitas das vendas de subprodutos e produtos da exploração florestal de 1 ha com araruva passariam a ser aquelas contidas na tabela 63.

Tabela 63 - Receitas das vendas de subprodutos e produtos da exploração florestal de 1 ha de araruva incorporando o efeito da heterogeneidade da população

\begin{tabular}{c|c|c|c}
\hline $\begin{array}{c}\text { Idade } \\
\text { (anos) }\end{array}$ & $\begin{array}{c}\text { Volume Retirado } \\
\left(\mathrm{m}^{3} / \mathrm{ha}\right)\end{array}$ & $\begin{array}{c}\text { Preço Unitário } \\
\left(\mathrm{R} \$ / \mathrm{m}^{3}\right)\end{array}$ & $\begin{array}{c}\text { Receita Total } \\
(\mathrm{R} \$)\end{array}$ \\
\hline 10 & 4,00 & 3,00 & 12,00 \\
11 & 10,00 & 3,00 & 30,00 \\
12 & 5,00 & 3,00 & 15,00 \\
13 & 6,00 & 3,00 & 18,00 \\
14 & 18,19 & 3,00 & 54,57 \\
16 & 37,65 & 20,00 & 753,00 \\
25 & 280,24 & 68,62 & 19230,07 \\
\hline
\end{tabular}

Fonte: Gurgel Filho et al. (1982a); Gurgel Filho et al. (1978); dados de pesquisa;e, valores calculados pelo autor. 
Apêndice 9 - Aspectos gerais da análise de risco pela simulação de Monte Carlo 
A análise de risco pelo método de Monte Carlo foi realizada com o auxílio do Software ALEAXPRJ '. Este permite a análise de problemas complexos que envolvem variáveis aleatórias numa análise em condição de risco. Segundo Takitane (1988) "uma das contribuições do software é o conhecimento das condições de unicidades em projetos que usualmente seriam tidos como possuidores de múltiplas taxas de retorno".

$\mathrm{Na}$ ausência de maiores informações sobre as distribuições de probabilidade das variáveis aleatórias, utiliza-se a distribuição triangular. Esta permite uma boa flexibilidade quanto ao grau de assimetria, permitindo uma característica positiva para a estimação subjetiva da distribuição. A distribuição triangular é definida pelo valor mais provável a moda (m), e pelos valores mínimo (a) e máximo (b), assumidos pela variável $\mathrm{x}$. No presente caso considerou-se a moda igual ao valor médio. A probabilidade é definida por: $\operatorname{Prob}\{\mathrm{a} \leq \mathrm{x} \leq \mathrm{b}\}=1$.

Nos quadros I1, I2 e I3 são apresentadas todas as variáveis aleatórias, os valores mínimo, médio e máximo e a definição das variáveis. Por se tratar de 18 tipos de projetos que geram uma grande quantidade de informações, as estimativas dos indicadores foram apresentadas de forma resumidas nas tabelas de 10 a 15 no capítulo 5, item 5.5.

\footnotetext{
${ }^{1}$ Maiores detalhes: Azevedo Filho, 1988. ALEAXPRJ - Sistema para Simulação e Análise Econômica de Projetos em Condições de Risco: manual do usuário. USP/PCP/CIAGRI - 1988. 43p.
} 
Quadro 6 - Definições das variáveis para a análise de risco dos projetos de pau-marfim

\begin{tabular}{|c|c|c|c|c|}
\hline \multirow[t]{2}{*}{ Variável } & \multicolumn{3}{|c|}{ Valores } & \multirow[t]{2}{*}{ Definição da variável } \\
\hline & mínimo & médio & Máximo & \\
\hline Preço da lenha & 1,00 & 3,00 & 5,00 & $\begin{array}{l}\text { Valores praticados para a cultura do eucalipto no } \\
\text { Estado de São Paulo }\end{array}$ \\
\hline Preço do moirão & 11,00 & 20,00 & 25,00 & $\begin{array}{l}\text { Valores praticados para a cultura do eucalipto no } \\
\text { Estado de São Paulo }\end{array}$ \\
\hline Preço da tora & 121,69 & 201,47 & 430,43 & $\begin{array}{l}\text { Valores obtidos a partir dos preços de toras de } \\
\text { matas nativas no Estado do Pará (1974 a 1999) e } \\
\text { do preço da tora do pau-marfim na análise } \\
\text { determinista }\end{array}$ \\
\hline $\begin{array}{l}\text { Produção de lenha } \\
\text { (ano 12) }\end{array}$ & 16,86 & 21,07 & 26,34 & $\begin{array}{l}\text { Valor médio igual ao da análise determinista, } \\
\text { valor mínimo } 20 \% \text { menor (baseado na cultura do } \\
\text { eucalipto) e valor máximo } 25 \% \text { maior (baseado } \\
\text { no cenário positivo } 1.1 .1 \text { do apêndice } 6 \text { ). }\end{array}$ \\
\hline $\begin{array}{l}\text { Produção de lenha } \\
\text { (ano 13) }\end{array}$ & 16,86 & 21,07 & 26,34 & Idem da variável anterior \\
\hline $\begin{array}{l}\text { Produção de lenha } \\
\text { (ano 14) }\end{array}$ & 16,86 & 21,07 & 26,34 & Idem da variável anterior \\
\hline $\begin{array}{l}\text { Produção de lenha } \\
\text { (ano 15) }\end{array}$ & 16,86 & 21,07 & 26,34 & Idem da variável anterior \\
\hline $\begin{array}{l}\text { Produção de moirão } \\
\text { (ano 20) }\end{array}$ & 26,71 & 33,39 & 41,74 & Idem da variável anterior \\
\hline $\begin{array}{l}\text { Produção de tora } \\
\text { (ano 25) }\end{array}$ & 137,87 & 172,34 & 215,43 & Idem da variável anterior \\
\hline $\begin{array}{l}\text { Custo de Implantação } \\
\text { considerando compra } \\
\text { de mudas (ano 0) }\end{array}$ & 763,72 & 1018,29 & 1120,12 & $\begin{array}{l}\text { Valor médio igual ao da análise determinista, } \\
\text { valor mínimo } 25 \% \text { menor e valor máximo } 10 \% \\
\text { maior do que o valor médio. Variações } \\
\text { percentuais observadas para a cultura do } \\
\text { eucalipto. }\end{array}$ \\
\hline $\begin{array}{l}\text { Custo de Implantação } \\
\text { considerando doação } \\
\text { de mudas (ano 0) }\end{array}$ & 223,91 & 298,54 & 328,39 & Idem da variável anterior \\
\hline $\begin{array}{l}\text { Custo de manutenção } \\
\text { (ano 1) }\end{array}$ & 129,06 & 161,32 & 225,85 & $\begin{array}{l}\text { Valor médio igual ao da análise determinista, } \\
\text { valor mínimo } 20 \% \text { menor e valor máximo } 40 \% \\
\text { maior do que o valor médio. Variações } \\
\text { percentuais observadas para a cultura do } \\
\text { eucalipto. }\end{array}$ \\
\hline $\begin{array}{l}\text { Custo de manutenção } \\
\text { (anos } 2 \text { e } 3 \text { ) }\end{array}$ & 53,05 & 66,31 & 92,83 & Idem da variável anterior \\
\hline $\begin{array}{l}\text { Custo de manutenção } \\
\text { (ano } 4 \text { a 25) }\end{array}$ & 14,90 & 18,63 & 29,81 & $\begin{array}{l}\text { Valor médio igual ao da análise determinista, } \\
\text { valor mínimo } 20 \% \text { menor e valor máximo } 60 \% \\
\text { maior do que o valor médio. Variações } \\
\text { percentuais observadas para a cultura do } \\
\text { eucalipto. }\end{array}$ \\
\hline $\begin{array}{l}\text { Preço da terra nua } \\
\text { para reflorestamento }\end{array}$ & 1471,18 & 3091,97 & 6414,64 & $\begin{array}{l}\text { Valores calculados para o Estado de São Paulo } \\
\text { entre os anos de } 1974 \text { e } 1999 .\end{array}$ \\
\hline $\begin{array}{l}\text { Valor do } \\
\text { Arrendamento }\end{array}$ & 147,53 & 322,69 & 703,41 & Idem da variável anterior \\
\hline
\end{tabular}

Fonte: dados de pesquisa e valores calculados pelo autor 
Quadro 7 - Definições das variáveis para a análise de risco dos projetos de pinheiro-brasileiro

\begin{tabular}{|c|c|c|c|c|}
\hline \multirow[t]{2}{*}{ Variável } & \multicolumn{3}{|c|}{ Valores } & \multirow[t]{2}{*}{ Definição da variável } \\
\hline & mínimo & médio & Máximo & \\
\hline Preço da lenha & 1,00 & 3,00 & 5,00 & $\begin{array}{l}\text { Valores praticados para a cultura do eucalipto no } \\
\text { Estado de São Paulo }\end{array}$ \\
\hline Preço do moirão & 11,00 & 20,00 & 25,00 & $\begin{array}{l}\text { Valores praticados para a cultura do eucalipto no } \\
\text { Estado de São Paulo }\end{array}$ \\
\hline Preço da tora & 96,80 & 160,26 & 342,39 & $\begin{array}{l}\text { Valores obtidos a partir dos preços de toras de } \\
\text { matas nativas no Estado do Pará (1974 a 1999) e } \\
\text { do preço da tora do pinheiro-brasileiro na análise } \\
\text { determinista }\end{array}$ \\
\hline $\begin{array}{l}\text { Produção de lenha } \\
\text { (ano 6) }\end{array}$ & 3,47 & 4,34 & 6,51 & $\begin{array}{l}\text { Valor médio igual ao da análise determinista } \\
\text { valor mínimo } 20 \% \text { menor (baseado na cultura do } \\
\text { eucalipto) e valor máximo } 50 \% \text { maior (baseado } \\
\text { no cenário positivo } 2.1 .1 \text { ). }\end{array}$ \\
\hline $\begin{array}{l}\text { Produção de lenha } \\
\text { (ano 10) }\end{array}$ & 3,47 & 4,34 & 6,51 & Idem da variável anterior \\
\hline $\begin{array}{l}\text { Produção de lenha } \\
\text { (ano 12) }\end{array}$ & 3,47 & 4,34 & 6,51 & Idem da variável anterior \\
\hline $\begin{array}{l}\text { Produção de moirão } \\
\text { (ano 21) }\end{array}$ & 25,40 & 31,75 & 47,63 & Idem da variável anterior \\
\hline $\begin{array}{l}\text { Produção de tora } \\
\text { (ano 25) }\end{array}$ & 197,58 & 246,58 & 370,47 & Idem da variável anterior \\
\hline $\begin{array}{l}\text { Custo de Implantação } \\
\text { considerando compra } \\
\text { de mudas (ano 0) }\end{array}$ & 528,24 & 704,32 & 774,75 & $\begin{array}{l}\text { Valor médio igual ao da análise determinista } \\
\text { valor mínimo } 25 \% \text { menor e valor máximo } 10 \% \\
\text { maior do que o valor médio. Variações } \\
\text { percentuais observadas para a cultura do } \\
\text { eucalipto. }\end{array}$ \\
\hline $\begin{array}{l}\text { Custo de Implantação } \\
\text { considerando doação } \\
\text { de mudas (ano 0) }\end{array}$ & 223,91 & 298,54 & 328,39 & Idem da variável anterior \\
\hline $\begin{array}{l}\text { Custo de manutenção } \\
\text { (ano 1) }\end{array}$ & 129,06 & 161,32 & 225,85 & $\begin{array}{l}\text { Valor médio igual ao da análise determinista } \\
\text { valor minimo } 20 \% \text { menor e valor máximo } 40 \% \\
\text { maior do que o valor médio. Variações } \\
\text { percentuais observadas para a cultura do } \\
\text { eucalipto. }\end{array}$ \\
\hline $\begin{array}{l}\text { Custo de manutenção } \\
\text { (anos } 2 \text { e } 3 \text { ) }\end{array}$ & 53,05 & 66,31 & 92,83 & Idem da variável anterior \\
\hline $\begin{array}{l}\text { Custo de manutenção } \\
\text { (ano } 4 \text { a 25) }\end{array}$ & 14,90 & 18,63 & 29,81 & $\begin{array}{l}\text { Valor médio igual ao da análise determinista, } \\
\text { valor mínimo } 20 \% \text { menor e valor máximo } 60 \% \\
\text { maior do que o valor médio. Variações } \\
\text { percentuais observadas para a cultura do } \\
\text { eucalipto. }\end{array}$ \\
\hline $\begin{array}{l}\text { Preço da terra nua } \\
\text { para reflorestamento }\end{array}$ & 1471,18 & 3091,97 & 6414,64 & $\begin{array}{l}\text { Valores calculados para o Estado de São Paulo } \\
\text { entre os anos de } 1974 \text { e } 1999 .\end{array}$ \\
\hline $\begin{array}{l}\text { Valor do } \\
\text { Arrendamento }\end{array}$ & 147,53 & 322,69 & 703,41 & Idem da variável anterior \\
\hline
\end{tabular}

Fonte: dados de pesquisa e valores calculados pelo autor 
Quadro 8 - Definições das variáveis para a análise de risco dos projetos de araruva

\begin{tabular}{|c|c|c|c|c|}
\hline \multirow[t]{2}{*}{ Variável } & \multicolumn{3}{|c|}{ Valores } & \multirow[t]{2}{*}{ Definição da variável } \\
\hline & mínimo & médio & Máximo & \\
\hline Preço da lenha & 1,00 & 3,00 & 5,00 & $\begin{array}{l}\text { Valores praticados para a cultura do eucalipto no } \\
\text { Estado de São Paulo }\end{array}$ \\
\hline Preço do moirão & 11,00 & 20,00 & 25,00 & $\begin{array}{l}\text { Valores praticados para a cultura do eucalipto no } \\
\text { Estado de São Paulo }\end{array}$ \\
\hline Preço da tora & 114,37 & 189,35 & 404,54 & $\begin{array}{l}\text { Valores obtidos a partir dos preços de toras de } \\
\text { matas nativas no Estado do Pará (1974 a 1999) e } \\
\text { do preço da tora da araruva na análise } \\
\text { determinista }\end{array}$ \\
\hline $\begin{array}{l}\text { Produção de lenha } \\
\text { (ano 10) }\end{array}$ & 3,20 & 4,00 & 5,54 & $\begin{array}{l}\text { Valor médio igual ao da análise determinista, } \\
\text { valor mínimo } 20 \% \text { menor (baseado na cultura do } \\
\text { eucalipto) e valor máximo } 38,48 \% \text { maior } \\
\text { (baseado no cenário positivo } 3.1 .1 \text { ). } \\
\end{array}$ \\
\hline $\begin{array}{l}\text { Produção de lenha } \\
\text { (ano 11) }\end{array}$ & 8,00 & 10,00 & 13,85 & Idem da variável anterior \\
\hline $\begin{array}{l}\text { Produção de lenha } \\
\text { (ano 12) }\end{array}$ & 4,00 & 5,00 & 6,92 & Idem da variável anterior \\
\hline $\begin{array}{l}\text { Produção de lenha } \\
\text { (ano 13) }\end{array}$ & 4,80 & 6,00 & 8,31 & Idem da variável anterior \\
\hline \begin{tabular}{|l}
$\begin{array}{l}\text { Produção de lenha } \\
\text { (ano 14) }\end{array}$ \\
\end{tabular} & 14,55 & 18,19 & 25,19 & Idem da variável anterior \\
\hline $\begin{array}{l}\text { Produção de moirão } \\
\text { (ano 16) }\end{array}$ & 30,12 & 37,65 & 52,14 & Idem da variável anterior \\
\hline $\begin{array}{l}\text { Produção de tora } \\
\text { (ano 25) }\end{array}$ & 224,19 & 280,24 & 388,08 & Idem da variável anterior \\
\hline $\begin{array}{l}\text { Custo de Implantação } \\
\text { considerando compra } \\
\text { de mudas (ano } 0 \text { ) }\end{array}$ & 908,65 & 1211,00 & 1332,10 & $\begin{array}{l}\text { Valor médio igual ao da análise determinista, } \\
\text { valor mínimo } 25 \% \text { menor e valor máximo } 10 \% \\
\text { maior do que o valor médio. Variações } \\
\text { percentuais observadas para a cultura do } \\
\text { eucalipto. }\end{array}$ \\
\hline $\begin{array}{l}\text { Custo de Implantação } \\
\text { considerando doação } \\
\text { de mudas (ano 0) }\end{array}$ & 160,21 & 213,61 & 234,97 & Idem da variável anterior \\
\hline $\begin{array}{l}\text { Custo de manutenção } \\
\text { (ano 1) }\end{array}$ & 129,06 & 161,32 & 225,85 & $\begin{array}{l}\text { Valor médio igual ao da análise determinista, } \\
\text { valor mínimo } 20 \% \text { menor e valor máximo } 40 \% \\
\text { maior do que o valor médio. Variações } \\
\text { percentuais observadas para a cultura do } \\
\text { eucalipto. }\end{array}$ \\
\hline $\begin{array}{l}\text { Custo de manutenção } \\
\text { (anos 2 e 3) }\end{array}$ & 53,05 & 66,31 & 92,83 & Idem da variável anterior \\
\hline $\begin{array}{l}\text { Custo de manutenção } \\
\text { (ano } 4 \text { a 25) }\end{array}$ & 14,90 & 18,63 & 29,81 & $\begin{array}{l}\text { Valor médio igual ao da análise determinista, } \\
\text { valor mínimo } 20 \% \text { menor e valor máximo } 60 \% \\
\text { maior do que o valor médio. Variações } \\
\text { percentuais observadas para a cultura do } \\
\text { eucalipto. }\end{array}$ \\
\hline $\begin{array}{l}\text { Preço da terra nua } \\
\text { para reflorestamento }\end{array}$ & 1471,18 & 3091,97 & 6414,64 & $\begin{array}{l}\text { Valores calculados para o Estado de São Paulo } \\
\text { entre os anos de } 1974 \text { e } 1999 .\end{array}$ \\
\hline $\begin{array}{l}\text { Valor do } \\
\text { Arrendamento }\end{array}$ & 147,53 & 322,69 & 703,41 & Idem da variável anterior \\
\hline
\end{tabular}

Fonte: dados de pesquisa e valores calculados pelo autor 